\title{
ESTUDO DO COMPORTAMENTO DE SOLO NÃO SATURADO ATRAVÉS DE PROVAS DE CARGA EM PLACA
}

\author{
Yuri Daniel Jatobá Costa
}

Dissertação apresentada à Escola de Engenharia de São Carlos da Universidade de São Paulo, como parte dos requisitos para a obtenção do título de Mestre em Geotecnia

ORIENTADOR: Prof. Dr. José Carlos Angelo Cintra

São Carlos

1999 
Ficha catalográfica preparada pela Seção de Tratamento da Informação do Serviço de Biblioteca - EESC - USP

Costa, Yuri Daniel Jatobá
Estudo do comportamento de solo não
saturado através de provas de carga em placa /
Yuri Daniel Jatobá Costa. São Carlos, 1999.
Dissertação (Mestrado) - Escola de
Engenharia de São Carlos - Universidade de São
Paulo, 1999.
Orientador: Prof. Dr. José Carlos Angelo
Cintra
I. Fundações. 2. Solo não saturado.
Título




\section{FOLHA DE APROVAÇÃO}

Candidato: Engenheiro YURI DANIEL JATOBÁ COSTA

Dissertação defendida e aprovada em 20-12-1999 pela Comissão Julgadora:

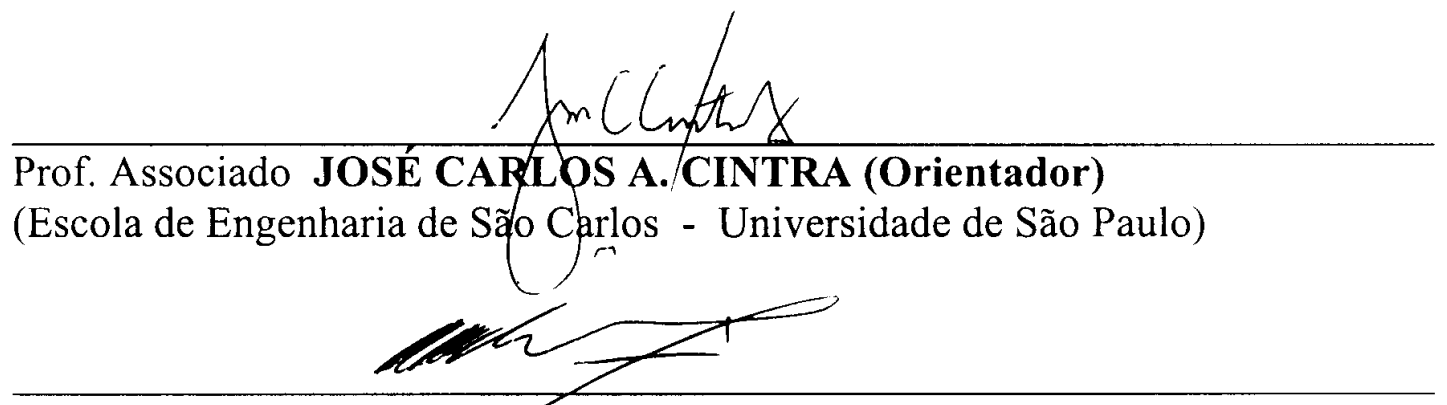

\section{Prof. Associado ORENCIO MONJE VILAR}

(Escola de Engenharia de São Carlos - Universidade de São Paulo)
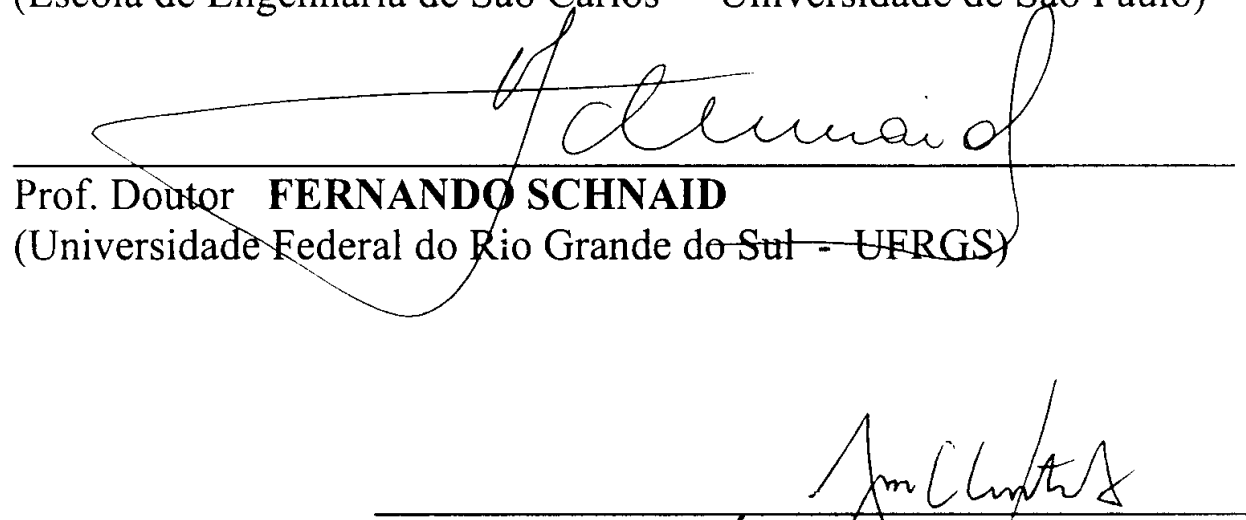

JOSÉ CARLOS A CINTRA

Coordenador da Área/de Geotecnia

Presidente da Comissão de Pós-Graduação da EESC 
"Só Sei de Uma Coisa:

Que Nada Sei”.

Sócrates

470 - 399 a.C.

A minha esposa, Carina a minha mãe, Tânia e a meu avô, Wilson,

dedico esta dissertação. 


\section{AGRADECIMENTOS}

Ao Prof. Dr. José Carlos Angelo Cintra pela valiosa orientação durante o desenvolvimento do presente trabalho.

Aos colegas Benedito Carneiro, Floriano Medeiros, Jeselay Cordeiro dos Reis, Mauro Menegotto, Nilton Campelo e Sidnei Teixeira, pelo inestimável apoio, principalmente com respeito ao árduo trabalho dispensado durante a execução das provas de carga.

Aos professores Orencio Monje Vilar e Nelson Aoki pelas importantes sugestões fornecidas no decorrer do trabalho e no Exame de Qualificação.

À Fundação de Amparo à Pesquisa do Estado de São Paulo - FAPESP, pelo auxílio financeiro e pela concessão da bolsa de estudo.

A todos os colegas, professores e funcionários do departamento de Geotecnia da USP/São Carlos pela cooperação. 


\section{SUMÁRIO}

LISTA DE FIGURAS i

LISTA DE TABELAS viii

LISTA DE ABREVIATURAS E SIGLAS $\quad \mathrm{x}$

LISTA DE SÍMBOLOS - xi

RESUMO Xiii

ABSTRACT Xiv

1 INTRODUÇÃO

1.1 Generalidades 1

1.2 Objetivos 2

1.3 Organização do texto 3

2 REVISÃO BIBLIOGRÁFICA

2.1 Prova de carga direta 5

2.1.1 Resultados típicos 6

2.1.2 Tipos de ensaio $\quad 8$

2.1.3 Interpretação dos resultados 10

2.1.4 Considerações sobre a influência da dimensão da placa nos $\begin{array}{ll}\text { resultados de recalque } & 16\end{array}$

2.1.5 Verificação do colapso do solo através de provas de carga em $\begin{array}{ll}\text { placa } & 20\end{array}$

2.1.6 Considerações sobre a influência da sucção 28

2.2 TDR: uma nova alternativa para a determinação do teor de umidade do solo

2.2.1 A constante dielétrica

2.2.2 O princípio da técnica de TDR 
2.2.3 A influência de outros parâmetros na constante dielétrica do solo

2.2.4 Modelos de sonda

2.2.5 O emprego da técnica em campo

2.2.6 Utilização da técnica para obtenção da sucção

3 LOCAL DA PESQUISA

3.1 Geologia local

3.2 Campo experimental de fundações $\quad 54$

4 MATERIAIS E MÉTODOS 58

$\begin{array}{ll}\text { 4.1 Provas de carga em placa } & 58\end{array}$

4.1.1 Tipos de ensaios realizados $\quad 59$

$\begin{array}{ll}\text { 4.1.2 Processo de inundação } & 61\end{array}$

$\begin{array}{ll}\text { 4.1.3 Tempo de inundação } & 61\end{array}$

4.1.4 Equipamentos e materiais utilizados $\quad 62$

4.1.5 Sistema de reação 66

4.2 Medidas de umidade e sucção em campo $\quad 67$

4.2.1 Reflectometria no domínio do tempo (TDR) 68

$\begin{array}{ll}4.2 .2 \text { Tensiometria } & 71\end{array}$

$\begin{array}{ll}\text { 4.2.3 Retirada de amostras deformadas } & 71\end{array}$

4.3 Ensaios de laboratório para correlacionar constante dielétrica, umidade volumétrica e sucção

5 APRESENTAÇÃO DOS RESULTADOS

$\begin{array}{ll}\text { 5.1 Curvas tensão-recalque } & 74\end{array}$

5.2 Correlaç̧̃̃es entre constante dielétrica, umidade volumétrica e sucção 78

5.2.1 Constante dielétrica e umidade volumétrica 78

$\begin{array}{ll}\text { 5.2.2 Constante dielétrica e sucção } & 78\end{array}$

5.3 Medidas de teor de umidade e sucção em campo 80

5.3.1 Reflectometria no domínio do tempo (TDR) 80 
6 ANÁLISE DOS RESULTADOS 86

6.1 Provas de carga $\quad 86$

6.1.1 Tempo de inundação e grau de saturação do solo nos ensaios inundados

6.1.2 Valores de sucção representativos das provas de carga 87

6.1.3 Tensão de ruptura e tensão de colapso $\quad 88$

6.1.4 Influência da sucção na resposta do sistema 89

6.1.5 Redução da tensão de ruptura devido ao colapso 92

6.1.6 Realização de ensaios mistos 92

6.1.7 Ensaio SML versus ensaio QML 96

6.1.8 Realização de reensaios 97

6.1.9 Comparações com ensaios de compressão confinada 99

6.2 Modelagem numérica das provas de carga em placa 102

6.2.1 Estado inicial de tensões no solo 103

6.2.2 Modelagem dos ensaios de placa 105

6.3 Reflectometria no domínio do tempo (TDR) 107

6.3.1 Comparações entre os métodos 107

6.3.2 Repetibilidade da técnica 113

7 CONCLUSÕES E SUGESTÕES PARA PESQUISAS FUTURAS 115

$\begin{array}{ll}7.1 \text { Conclusões } & 115\end{array}$

$\begin{array}{ll}\text { 7.2 Sugestões para pesquisas futuras } & 117\end{array}$

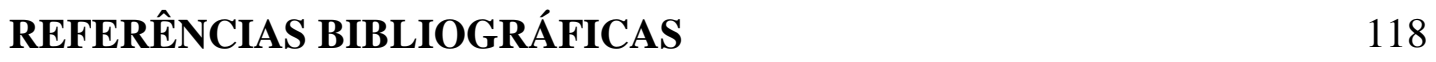

$\begin{array}{ll}\text { ANEXO A } & 132\end{array}$

$\begin{array}{lr}\text { ANEXO B } & 138\end{array}$ 


\section{LISTA DE FIGURAS}

FIGURA 2.1 - Curva tensão-recalque 6

FIGURA 2.2 - Curva tensão-recalque com ocorrência de pico de tensão máxima

FIGURA 2.3 - Curva tensão-recalque com comportamento de encruamento do solo

FIGURA 2.4 - a) carregamento sobre uma área circular num maciço semi-infinito; b) variação do módulo cisalhante com a profundidade (POULOS \& DAVIS, 1973)

FIGURA 2.5 - Recalque no centro de uma área circular (POULOS \& DAVIS, 1973)

FIGURA 2.6 - Relação entre recalques $s$ e largura (ou diâmetro) $B$ de sapatas e placas rígidas para uma tensão constante aplicada (GORBONOV-POSSADOV \& DAVIDOV, 1973)

FIGURA 2.7 - Relação entre o coeficiente de recalque e a razão tamanho da placa/tamanho da fundação segundo TERZAGHI \& PECK (1948) e BJERRUM \& EGGESTAD (1963) (SIMONS \& MENZIES, 1981)

FIGURA 2.8 - Ensaios de placa em solo homogêneo, sem coesão e cimentado em termos de tensão versus recalque normalizado (CONSOLI et al. , 1998)

FIGURA 2.9 - Provas de carga em placa na umidade natural e com inundação (CARVALHO \& SOUZA, 1990)

FIGURA 2.10 - Resultados de provas de carga conduzidas na prof. de $2 \mathrm{~m}$ (AGNELLI, 1992)

FIGURA 2.11 - Resultados de provas de carga em placa com diferentes líquidos de inundação (AGNELLI, 1997) 
FIGURA 2.12 - Resultados de ensaios de placa realizados por FERREIRA et al. (1998). A - Sta. Maria da Boa Vista. B - Petrolândia

FIGURA 2.13 - Fundação superficial em solo "parcialmente submerso"

FIGURA 2.14 - Capacidade de carga de sapatas em modelo na superfície de uma areia parcialmente submersa (MEYERHOF, 1955)

FIGURA 2.15 - Curvas tensão-recalque de ensaios em modelos (STEESEN-BACH et al., 1987)

FIGURA 2.16 - Variação da "atração" com a sucção medida (STEESEN-BACH et al., 1987)

FIGURA 2.17 - Tensão de ruptura de sapatas corridas para vários valores de sucção matricial (FREDLUND \& RAHARDJO, 1993)

FIGURA 2.18 - Esquema de um equipamento utilizado na técnica de TDR (CONCIANI et al., 1995)

FIGURA 2.19 - Relação entre constante dielétrica e umidade volumétrica para um solo argiloso e um solo arenoso (DASBERG \& HOPMANS, 1992)

FIGURA 2.20 - Relação entre teor de umidade volumétrica e constante dielétrica para cinco tipos de solo (HERKELRATH et al., 1991)

FIGURA 2.21 - Esquema de sonda coaxial empregada por TOPP et al. (1980)

FIGURA 2.22 - Esquemas de sondas segmentada e contínua empregadas por TOPP et al. (1982a, b)

FIGURA 2.23 - Esquema de sonda coaxial multi-hastes (ZEGELIN et al., 1989)

FIGURA 2.24 - Regiões abrangidas pelo campo elétrico das sondas (ZEGELIN et al., 1989) 
FIGURA 2.25 - Esquema da sonda concebida por BAKER \& GOODRICH (1987)

FIGURA 2.26 - $\theta_{\mathrm{g}}$ versus $\theta_{\mathrm{t}}$ para sondas de 50 a $300 \mathrm{~mm}$ (TOPP et al., 1984)

FIGURA 2.27 - Perfis de teor de umidade comparando dados de sondas verticais e horizontais com dados obtidos a partir de coleta de amostras (TOPP \& DAVIS, 1985)

FIGURA 2.28 - Perfis de teor de umidade obtidos através das técnicas de TDR e de sonda de nêutrons (BAKER \& ALLMARAS, 1990)

FIGURA 2.29 - Relação entre o potencial matricial e a profundidade do lençol freático (BAUMGARTNER et al., 1994)

FIGURA 2.30 - Curva de sucção matricial como uma função da constante dielétrica (CONCIANI et al., 1996)

FIGURA 2.31 - Curvas de calibração típicas para diversos sensores de sucção matricial, juntamente com a curva de calibração teórica (COOK \& FREDLUND, 1998)

FIGURA 3.1 - Perfil geológico da região de São Carlos (DAEE, apud VILAR, 1979)

FIGURA 3.2 - Distribuição dos depósitos de cobertura cenozóica do interior do Estado de São Paulo (FÚLFARO \& BJONBERG, 1993)

FIGURA 3.3 - Seção esquemática da geologia de pequena profundidade em São Carlos (CINTRA et al., 1991)

FIGURA 3.4 - Perfil típico do Campo Experimental de Fundações da USP-São Carlos

FIGURA 3.5 - Variação de índices físicos e de limites de consistência com a profundidade (Modificado de GIACHETI et al., 1993 e MACHADO, 1998) 
FIGURA 3.6 - Curvas granulométricas obtidas para as profundidades de 3, 5 e 8 m, no Campo Experimental de Fundações

(MACHADO, 1998)

FIGURA 4.1 - Disposição dos ensaios de placa no Campo Experimental da USP/São Carlos

FIGURA 4.2 - Detalhe da instalação de um extensômetro

FIGURA 4.3 - Torre de transferência de carga

FIGURA 4.4 - Barraca utilizada nas provas de carga

FIGURA 4.5 - Esquemas dos sistemas de reação, vistos em corte transversal

FIGURA 4.6 - Esquema geral das provas de carga realizadas

FIGURA 4.7 - Sonda utilizada

FIGURA 4.8 - Disposição das sondas de TDR, dos tensiômetros e da placa dentro da cava

FIGURA 4.9 - Testador de cabos utilizado

FIGURA 4.10 - Célula coaxial desmontada

FIGURA 4.11 - Corpo de prova dentro da Câmara de Richards confeccionada no Departamento de Geotecnia da USP/São Carlos

FIGURA 5.1 - Curvas tensão-recalque dos ensaios SML inundados

FIGURA 5.2 - Curvas tensão-recalque dos ensaios QML inundados

FIGURA 5.3 - Curvas tensão-recalque dos ensaios MML inundados

FIGURA 5.4 - Curvas tensão-recalque de S1 e S1-r. Recalques acumulados 
FIGURA 5.5 - Curvas tensão-recalque de Q1 e Q1-r. Recalques acumulados

FIGURA 5.6 - Curva tensão-recalque de S2

FIGURA 5.7 - Curva tensão-recalque de Q2

FIGURA 5.8 - Correlação entre constante dielétrica e umidade volumétrica

FIGURA 5.9 - Correlação entre constante dielétrica e sucção

FIGURA 5.10 - Curva característica do solo

FIGURA 5.11 - Variação da umidade volumétrica com a profundidade nas provas de carga não inundadas. Técnica de TDR

FIGURA 5.12 - Variação da sucção matricial com a profundidade nas provas de carga não inundadas. Técnica de TDR

FIGURA 5.13 - Frente de umedecimento em diversas profundidades. Técnica de TDR

FIGURA 5.14 - Variação da sucção matricial com a profundidade nas provas de carga não inundadas, verificada pelos tensiômetros

FIGURA 5.15 - Variação da umidade volumétrica com a profundidade nas provas de carga não inundadas. Coleta de amostras deformadas

FIGURA 6.1 - Curvas tensão-recalque dos ensaios SML realizados em diferentes níveis de sucção

FIGURA 6.2 - Curvas tensão-recalque dos ensaios QML realizados em diferentes níveis de sucção

FIGURA 6.3 - Variação de $\sigma_{\mathrm{r}}$ e $\sigma_{\mathrm{c}}$ dos ensaios SML e QML com a sucção matricial

FIGURA 6.4 - Ensaios inundados SML, QML e MML 
FIGURA 6.5 - Curva a: comportamento observado nos ensaios mistos. Curva b: comportamento hipotético

FIGURA 6.6 - Efeito do tipo de ensaio na resposta do sistema

FIGURA 6.7 - Ensaios SML inundados e reensaio S1-r

FIGURA 6.8 - Ensaios QML inundados e reensaio Q1-r

FIGURA 6.9 - Trajetórias seguidas durante ensaios oedométricos e provas de carga em placa

FIGURA 6.10 - Variação da tensão de pré-adensamento e da tensão de ruptura com a sucção

FIGURA 6.11 - Variação da tensão de ruptura das provas de carga SML e QML com a sucção e ajustes para a variação da tensão de pré-adensamento com a sucção

FIGURA 6.12 - Malha de elementos finitos

FIGURA 6.13 - Distribuição das tensões iniciais do solo em termos de tensões verticais (valores em $\mathrm{kPa}$ )

FIGURA 6.14 - Distribuição das tensões iniciais do solo em termos de tensões cisalhantes (valores em $\mathrm{kPa}$ )

FIGURA 6.15 - Zona de plastificação do solo e contornos de tensões verticais para uma tensão correspondente a um recalque de $80 \mathrm{~mm}$

FIGURA 6.16 - Comparação das curvas carga-recalque dos ensaios de campo com a obtida através da simulação numérica

FIGURA 6.17 - Variação da umidade volumétrica com a profundidade por gravimetria e TDR. Ensaio S1

FIGURA 6.18 - Variação da umidade volumétrica com a profundidade por gravimetria e TDR. Ensaio S2

FIGURA 6.19 - Variação da umidade volumétrica com a profundidade por gravimetria e TDR. Ensaio Q1 
FIGURA 6.20 - Variação da umidade volumétrica com a profundidade por gravimetria e TDR. Ensaio Q2

FIGURA 6.21 - Variação da sucção matricial com a profundidade por tensiometria e TDR. Ensaio S1

FIGURA 6.22 - Variação da sucção matricial com a profundidade por tensiometria e TDR. Ensaio S2

FIGURA 6.23 - Variação da sucção matricial com a profundidade por tensiometria e TDR. Ensaio Q1

FIGURA 6.24 - Variação da sucção matricial com a profundidade por tensiometria e TDR. Ensaio Q2 


\section{LISTA DE TABELAS}

TABELA 2.1 - Resultados de provas de carga direta realizadas por FERREIRA et al. (1990)

TABELA 2.2 - Recalques medidos nas provas de carga realizadas por CONCIANI (1997) e valores médios de sucção

TABELA 2.3 - Valores do potencial de colapso calculados com base na proposta de REZNIK (1993) (CONCIANI, 1997)

TABELA 2.4 - Influência do teor de umidade na tensão de ruptura e nos recalques (AMAR et al., 1987)

TABELA 3.1 - Alguns índices físicos do solo

TABELA 4.1 - Seqüência da realização das provas de carga

TABELA 5.1 - Valores de umidade volumétrica (\%) das provas de carga com inundação

TABELA 5.2 - Valores de sucção $(\mathrm{kPa})$ das provas de carga com inundação

TABELA 5.3 - Valores de umidade volumétrica (\%) das provas de carga não inundadas

TABELA 5.4 - Valores de sucção $(\mathrm{kPa})$ das provas de carga não inundadas

TABELA 6.1 - Tempo de chegada da frente e de estabilização do teor de umidade

TABELA 6.2 - Sucção adotada em cada prova de carga

TABELA 6.3 - Tensões de ruptura e de colapso nas provas de carga

TABELA 6.4 - Redução da tensão de ruptura em relação à tensão de colapso 
TABELA 6.5 - Propriedades do solo antes do inicio de S1-r e Q1-r

TABELA 6.6 - Parâmetros utilizados no modelo adotado

TABELA 6.7 - Erro dos valores de teor de umidade obtidos através da técnica de TDR

TABELA 6.8 - Erro dos valores de sucção obtidos pela técnica de TDR e de pesagem de amostras em relação aos fornecidos pelos tensiômetros 


\section{LISTA DE ABREVIATURAS E SIGLAS}

$\begin{array}{ll}\text { ABNT } & - \text { Associação Brasileira de Normas Técnicas } \\ \text { CLT } & - \text { Cyclic Load Test (Ensaio Cíclico) } \\ \text { CPT } & - \text { Cone Penetration Test (Ensaio de penetração do cone) } \\ \text { CRP } & - \text { Constant Rate of Penetration Test (Ensaio com taxa de penetração } \\ & \text { constante) } \\ \text { IPT } & - \text { Instituto de Pesquisas Tecnológicas } \\ \text { MML } & - \text { Mixed Manteined Load Test (Ensaio Misto) } \\ \text { NBR } & - \text { Norma Brasileira Registrada } \\ \text { QML } & - \text { Quick Manteined Load Test (Ensaio Rápido) } \\ \text { SML } & - \text { Slow Manteined Load Test (Ensaio Lento) } \\ \text { SPT } & - \text { Standard Penetration Test } \\ \text { TDR } & - \text { Time Domain Reflectometry (Reflectometria no Domínio do Tempo) } \\ \text { UNESP } & - \text { Universidade Estadual Paulista }\end{array}$




\section{LISTA DE SÍMBOLOS}

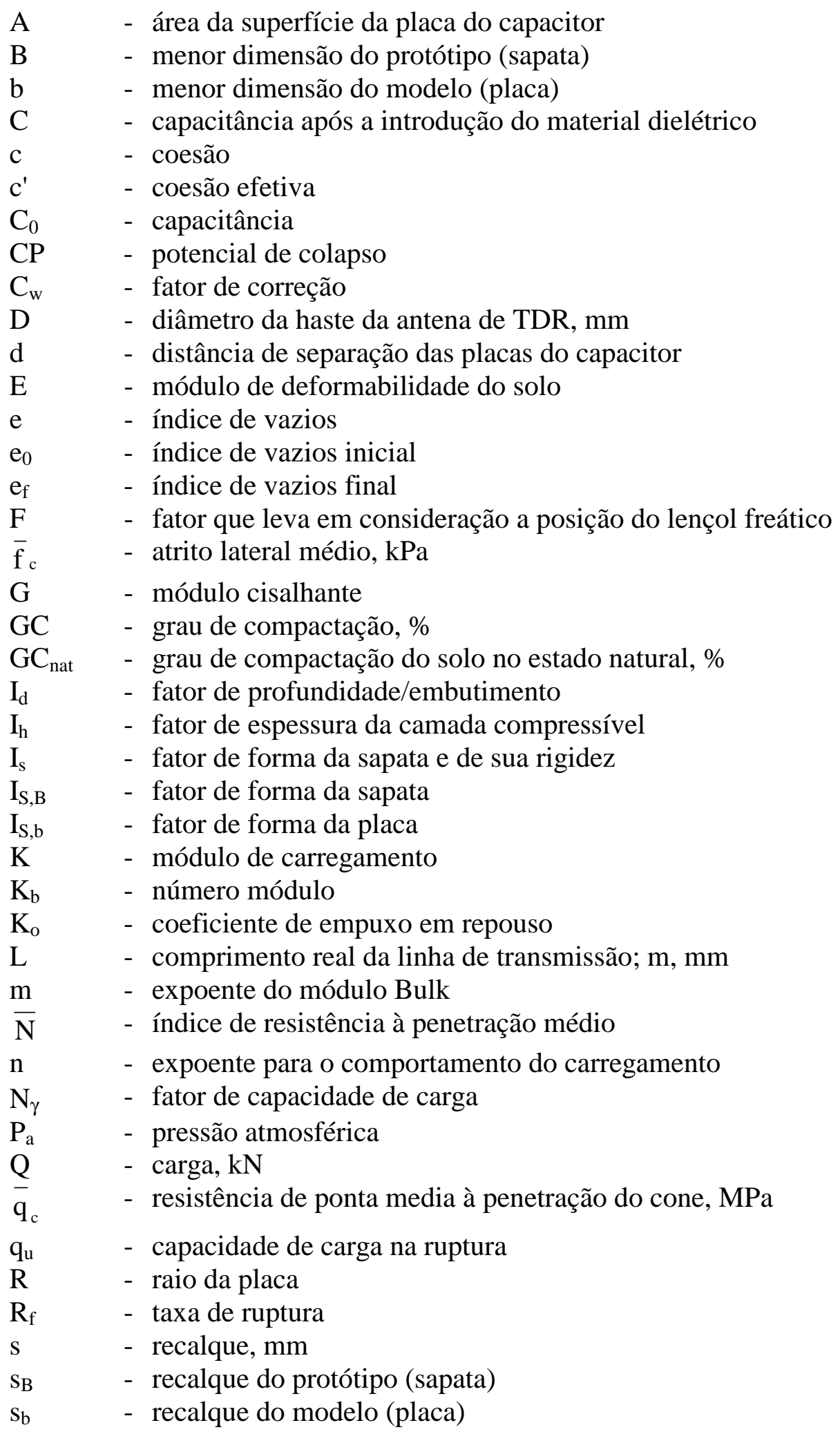




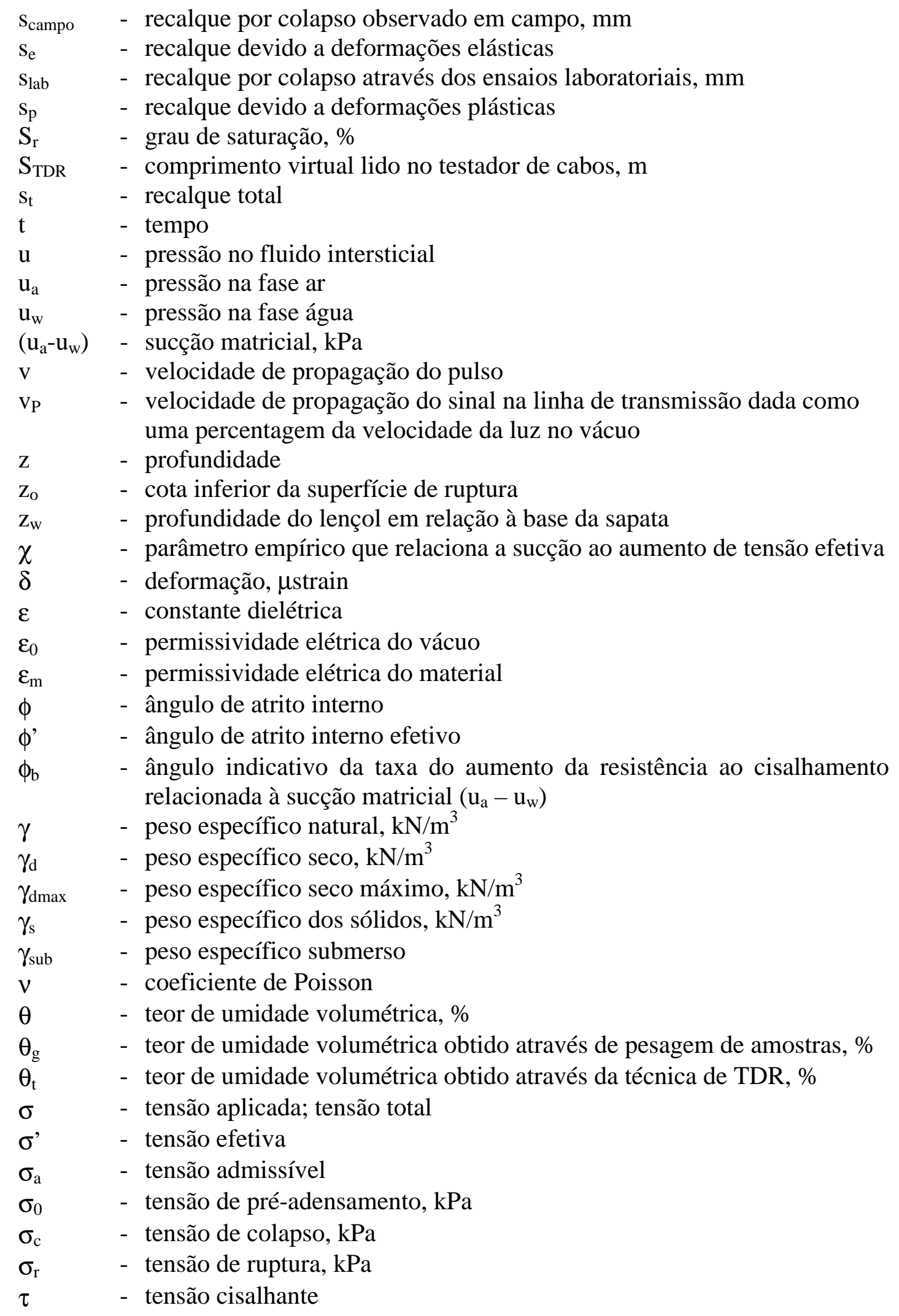




\section{RESUMO}

COSTA, Y. D. J. (1999). Estudo do comportamento de solo não saturado através de provas de carga em placa. São Carlos, 1999. 138p. Dissertação (Mestrado) - Escola de Engenharia de São Carlos, Universidade de São Paulo.

Este trabalho apresenta resultados de provas de carga em placa com monitoramento do teor de umidade e da sucção matricial do solo, realizadas a 1,5 m de profundidade em um solo não saturado e colapsível, considerado representativo da região centro-oeste do Estado de São Paulo. Foram executados ensaios com e sem inundação da cava, do tipo lento (SML), rápido (QML) e "misto" (lento até um determinado estágio, passando a rápido a partir de então). $\mathrm{O}$ acompanhamento do teor de umidade e da sucção durante os ensaios foi realizado através de pesagem de amostras, com a utilização da técnica de reflectometria no domínio do tempo (TDR) e com o auxílio de tensiômetros. A partir dos dados obtidos, procedeu-se a uma análise da influência da sucção na resposta do sistema solo-placa. Foi observado que o aumento da sucção provoca um crescimento substancial da capacidade de carga do solo. Comparando-se ensaios inundados com não inundados, observou-se que o colapso do solo mostra-se mais proeminente com o aumento da sucção. Com respeito à técnica de reflectometria no domínio do tempo, a mesma demonstrou um desempenho satisfatório para medidas de teor de umidade in situ.

Palavras-chave: prova de carga em placa; solos não saturados; solos colapsíveis; TDR. 


\section{ABSTRACT}

COSTA, Y. D. J. (1999). Study of the behavior of an unsaturated soil through plate load tests. São Carlos, 1999. 138p. Dissertação (Mestrado) - Escola de Engenharia de São Carlos, Universidade de São Paulo.

This work presents results of plate load tests with measurements of soil moisture content and matric suction, carried out at a $1.5 \mathrm{~m}$ depth in an unsaturated collapsible soil, considered as representative of the middle-west region of the State of São Paulo, Brazil. The tests were performed with and without the wetting of the pit. Three test methods were used: slow maintained load (SML), quick maintained load (QML), and "mixed" tests (SML up to a certain stage, switched to QML from there on). Soil moisture content and suction were measured through gravimetric determination on samples, the time domain reflectometry technique (TDR), and tensiometers. The gathered data allowed an assessment of the influence of the soil suction over the soil-plate system response. It was observed that the increase in suction causes a substantial increase in soil bearing capacity. Comparisons between wet and non-wet tests showed that soil collapse is higher when suction rises. The time domain reflectometry technique showed a promising performance with respect to in situ water content measurements.

Keywords: plate load test; unsaturated soils; collapsible soils; TDR. 


\section{1- INTRODUÇÃO}

\section{1 - GENERALIDADES}

Desde seus primórdios, a Mecânica dos Solos firmou seus conceitos considerando o solo na condição saturada. Isto pode ser compreendido devido ao fato da mesma ter sido concebida em países de clima temperado, onde ocorrem com mais frequiência solos sedimentares saturados. Em complementação, há ainda as dificuldades teóricas e práticas em se considerar a fase fluida do solo composta por ar e água. Não obstante, em diversas localidades a existência de solos não saturados representa uma realidade que não pode ser ignorada.

Embora prática comum, negligenciar o comportamento do solo não saturado pode resultar em projetos de elevado custo, bem como causar prejuízos em obras já existentes. Em diversas regiões brasileiras, como por exemplo o interior do Estado de São Paulo, há a ocorrência de solos colapsíveis que, indubitavelmente, tem representado um grande problema para a Engenharia de Fundações. Relatos de danos causados a estruturas assentes sobre este tipo de solo não são raros.

No caso de fundações superficiais, por constituir um modelo bastante próximo da realidade, a prova de carga direta tem sido empregada com frequiência como ferramenta para o estudo do comportamento de solos colapsíveis. Nas pesquisas realizadas com a utilização dessa modalidade de ensaio, buscava-se quantificar a redução de capacidade de carga devido ao colapso. Não se procurava estudar o comportamento do solo à luz dos conceitos relativos a solos não saturados. 
No entanto, estudos neste sentido são de suma importância para uma melhor compreensão do fenômeno.

Por outro lado, há algumas décadas, os fundamentos da Mecânica dos Solos tradicional têm sido gradualmente estendidos de modo a incorporar as particularidades dos solos não saturados. Por conseguinte, nada mais natural que os demais ramos da Geotecnia, com destaque à Engenharia de Fundações, evoluam na mesma direção, passando a empregar futuramente as conceituações referentes aos solos não saturados na prática.

\section{2 - OBJETIVOS}

$\mathrm{Na}$ intenção de contribuir para o despertar desta nova vertente, o presente trabalho tem por objetivo geral investigar o comportamento de um solo não saturado e colapsível através de provas de carga direta, com monitoramento do teor de umidade e da sucção do solo durante os ensaios.

Constituem objetivos específicos da pesquisa:

a) observar a influência da variação do teor de umidade e da sucção matricial nos resultados de capacidade de carga e de recalques, através da realização de ensaios lentos, rápidos e mistos no Campo Experimental de Fundações da USP/São Carlos;

b) comparar os resultados obtidos através dos ensaios lentos (SML) com os observados nos ensaios rápidos (QML), assim como verificar a adequação da realização de ensaios mistos ao solo estudado;

c) confrontar os resultados dos ensaios de placa com resultados de ensaios de laboratório oedométricos e triaxiais com sucção controlada;

d) determinar o teor de umidade e a sucção matricial in situ durante as provas de carga, com a utilização da técnica de reflectometria no domínio do tempo (TDR), de 
tensiômetros e da coleta de amostras deformadas. Averiguar a adequação da técnica de TDR.

\section{3 - ORGANIZAÇÃO DO TEXTO}

Além deste capítulo, a presente dissertação é dividida em mais seis partes. $\mathrm{O}$ capítulo 2 apresenta uma revisão bibliográfica composta por dois tópicos principais. No primeiro, são abordados alguns aspectos relativos à prova de carga direta, entre os quais a apresentação de trabalhos que estudaram o colapso do solo através da realização de prova de carga em placa e considerações sobre a influência da dimensão da placa e da sucção ${ }^{1}$ nos resultados. Finalmente, no último tópico é realizada uma revisão da literatura sobre a técnica de TDR, pelo fato de possuir aplicações ainda recentes em Geotecnia, bem como pela escassez de informações sobre a mesma na literatura nacional.

No capítulo 3, descreve-se o local da pesquisa: o Campo Experimental de Fundações da USP/São Carlos, apresentando-se ainda algumas considerações sobre a geologia da cidade de São Carlos.

No capítulo 4, são relacionadas as atividades desenvolvidas, discorrendo-se sobre os procedimentos adotados nos ensaios, os equipamentos e materiais utilizados, entre outros. Também é detalhadamente relatado o emprego das técnicas para a obtenção do teor de umidade e da sucção do solo nas provas de carga.

No capítulo 5, exibem-se os resultados referentes às provas de carga em placa e aos métodos utilizados para medidas de umidade e sucção in situ. Outrossim, são expostos os resultados correlacionando a constante dielétrica do solo com o teor de umidade e com a sucção.

1 - Sempre que o termo sucção é mencionado, deve-se subentendê-lo como sucção matricial. 
No capítulo 6, os resultados obtidos são analisados. Além das análises pertinentes aos resultados das provas de carga, discute-se também a adequação da técnica de TDR e comparam-se os resultados das provas de carga com os obtidos nos ensaios laboratoriais. Finalmente, no capítulo 7, são expostas as principais conclusões obtidas no trabalho e apresentadas sugestões para pesquisas futuras. 


\section{2 - REVISÃO BIBLIOGRÁFICA}

\section{1 - PROVA DE CARGA DIRETA}

A prova de carga direta é um ensaio estático de campo, realizado na superfície ou em profundidade, cujas principais finalidades residem na verificação do comportamento de um elemento de fundação sujeito a um determinado carregamento de compressão e na estimativa de parâmetros indicativos de resistência e de deformabilidade do solo suporte da futura construção.

Certamente, o melhor método para a determinação de recalques e da capacidade de carga de um sistema solo-fundação direta seria a utilização de um protótipo em tamanho real, no qual atuaria uma carga de projeto durante um longo período, de modo que todo o recalque pudesse ser observado. Em seguida, a carga seria aumentada paulatinamente até que a ruptura ocorresse. No entanto, uma prova de carga nas condições acima descritas seria praticamente inviável devido a problemas como o longo período necessário para sua execução e o alto custo. Dessa forma, em se tratando de fundações superficiais, a prova de carga em placa é tida, na maioria das vezes, como a melhor alternativa para a determinação de parâmetros e do comportamento do sistema.

A prova de carga em placa é considerada o mais antigo ensaio in situ de compressão, podendo ser admitida como "multissecular na história da engenharia" (BARATA, 1984). Segundo TEIXEIRA \& GODOY (1996), a mesma nasceu antes mesmo do surgimento das primeiras conceituações da Mecânica dos Solos. 
Atualmente, são inúmeros os trabalhos sobre o tema, sendo o de CUNHA ${ }^{1}$ (apud BARATA, 1984) um dos primeiros publicados no Brasil. Pode-se ainda citar como pioneiros os trabalhos de NÁPOLES NETO (1954) e SOUTO SILVEIRA \& SILVEIRA (1958), bem como o estudo realizado pelo Instituto de Pesquisas Tecnológicas (IPT, 1954) para as instalações da Escola de Engenharia de São Carlos, em cujo terreno foram executados três ensaios de placa em diferentes profundidades.

\subsection{1 - Resultados típicos}

Em uma prova de carga direta convencional, o recalque é medido ao longo do ensaio em função das tensões aplicadas em estágios crescentes. Em cada estágio, a tensão é mantida constante por um determinado período, até a estabilização dos recalques segundo algum critério adotado. Dessa maneira, torna-se possível traçar uma curva tensão $\sigma$ versus recalque $s$, como a OABC da Figura 2.1, sendo o trecho $\mathrm{OAB}$ correspondente à fase de carregamento e o trecho $\mathrm{BC}$, ao descarregamento. Através dessa curva, pode-se determinar as parcelas elástica $s_{e}$ e plástica $s_{p}$ do recalque total $s_{t}$. O trecho OA é aproximadamente retilíneo, representando a fase de deformações elásticas. Já o trecho $\mathrm{AB}$ apresenta certa curvatura, podendo assumir, em algumas situações, uma forma assintótica à reta $\sigma_{b} \mathrm{~B}$ em sua extremidade final, como mostra a Figura 2.1.

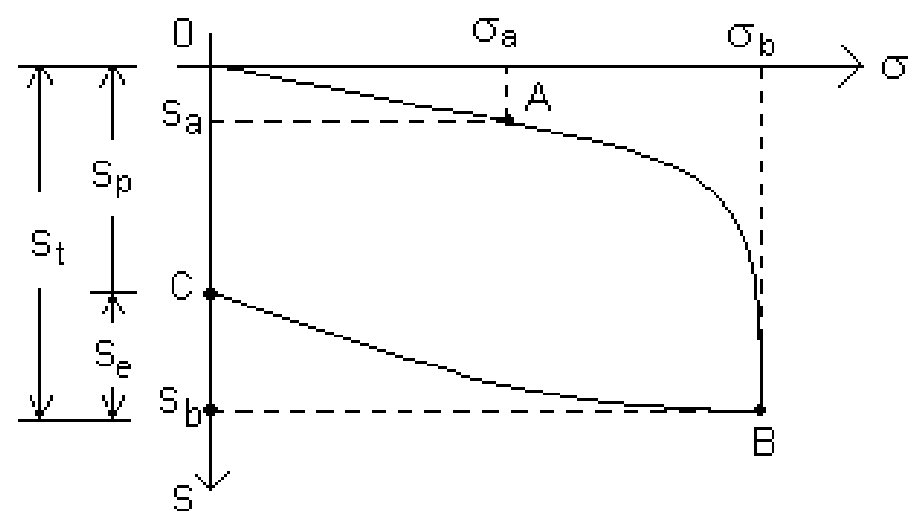

FIGURA 2.1 - Curva tensão-recalque

1- CUNHA, D. J. S. (1920). Experimentação dos terrenos para o estudo das fundações. Revista Brasileira de Engenharia. n.1, Rio de Janeiro. 
Quando a fundação é apoiada em solo rígido, como uma areia muito compacta, a curva tensão-recalque pode apresentar um pico bem definido, como expõe a Figura 2.2. No trecho OA, a relação entre $\sigma$ e $s$ é praticamente linear, ocorrendo no ponto $\mathrm{A}$ a máxima tensão $\sigma_{a}$ mobilizada no ensaio. $\mathrm{O}$ trecho $\mathrm{AB}$ exibe um decréscimo da tensão com o aumento do recalque. A partir do ponto B, $\sigma$ tornase constante com o aumento de $s$, sendo $\sigma_{b}$ denominada tensão residual.

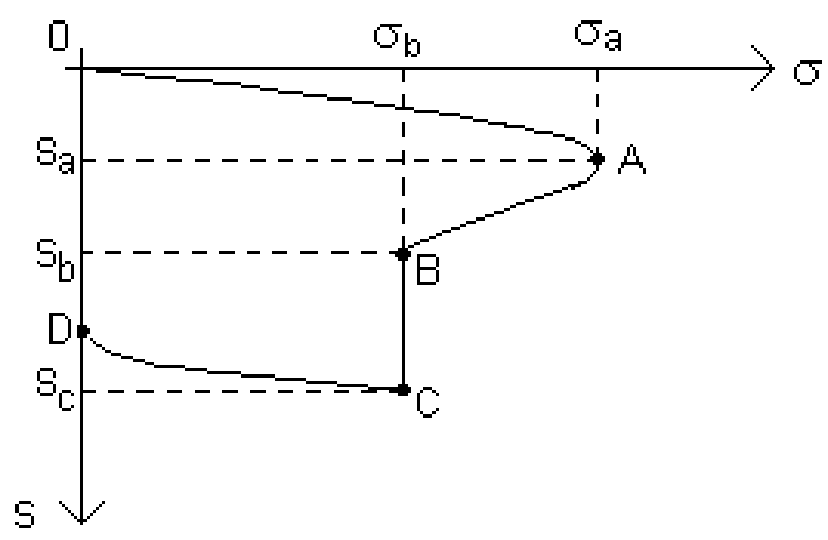

FIGURA 2.2 - Curva tensão-recalque com ocorrência de pico de tensão máxima

Uma outra forma característica de resposta do sistema é exibida na Figura 2.3, acontecendo em situações nas quais o solo apresenta comportamento de encruamento. $\mathrm{O}$ trecho $\mathrm{OA}$ representa a fase de deformações elásticas, seguido do trecho $\mathrm{AB}$, com determinada curvatura. $\mathrm{O}$ trecho $\mathrm{BC}$ é praticamente retilíneo, causado pelo enrijecimento crescente do solo com o aumento da tensão aplicada. 


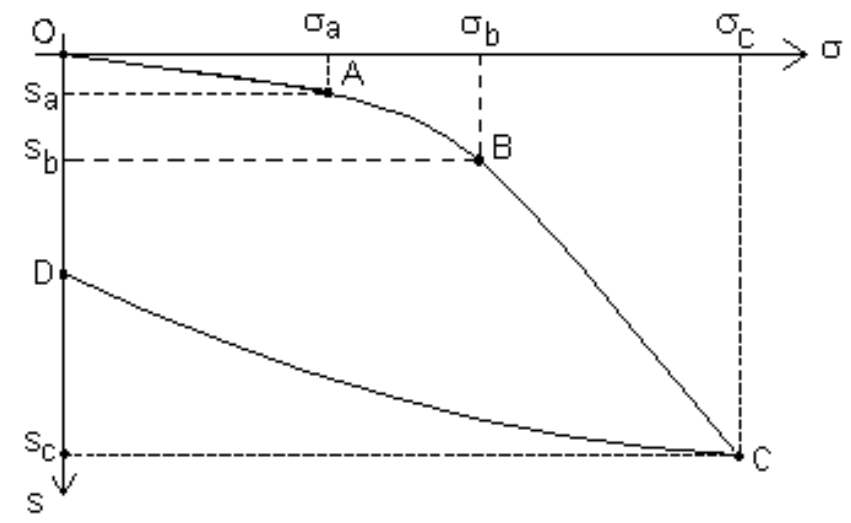

FIGURA 2.3 - Curva tensão-recalque com comportamento de encruamento do solo

\subsection{2 - Tipos de ensaio}

Os métodos de ensaio utilizados na prova de carga direta podem ser classificados da seguinte forma (FELLENIUS, 1975; MILITITSKY, 1991):

\section{Ensaio lento (Slow Manteined Load Test - SML)}

Neste tipo de ensaio, a duração de cada estágio de carregamento dependerá da estabilização dos deslocamentos, a qual segue algum critério pré-determinado. Constitui o tipo prescrito na NBR 6489/84 da ABNT - "Provas de carga direta sobre terreno de fundação". Segundo esta norma, a tensão deve ser aplicada em estágios crescentes de no máximo $20 \%$ da tensão admissível provável do solo, sendo a mudança de estágio somente efetuada quando a diferença entre duas leituras de recalques realizadas nos tempos $\mathrm{t}$ e $\mathrm{t} / 2$ não ultrapassar $5 \%$ do deslocamento total ocorrido no correspondente estágio de carregamento. Os recalques em cada estágio deverão ser lidos imediatamente após a aplicação da carga, em intervalos de tempo sucessivamente dobrados $(1,2,4,8,15 \mathrm{~min}, \ldots)$. A referida norma especifica ainda que o ensaio deve prosseguir até que seja observado um recalque total de $25 \mathrm{~mm}$ ou até que se tenha atingido o dobro da tensão admissível provável do solo, devendo a carga máxima, caso não seja alcançada a ruptura, ser mantida por no mínimo 12 horas. O descarregamento deve ocorrer em estágios sucessivos, não superiores a $25 \%$ da 
carga total, sendo os recalques lidos de forma similar ao carregamento, mantendo-se cada estágio até a estabilização.

Outros critérios de estabilização de deslocamentos adotados por outras normas para o ensaio SML podem ser obtidos em MILITITSKY (1991).

\section{Ensaio Rápido (Quick Manteined Load Test - QML)}

Nesta modalidade, um intervalo de tempo fixo é assumido para o término de cada estágio de carregamento, independente da estabilização dos deslocamentos. No Brasil, não há uma norma específica para o ensaio rápido em elemento de fundação superficial. Contudo, costuma-se adotar as especificações da MB-3472/91 - "Estacas

- Prova de Carga Estática" com respeito ao ensaio QML. Em cada estágio, a carga aplicada não ultrapassará $10 \%$ da tensão admissível prevista e será aplicada por um período de 5 minutos, sendo os deslocamentos lidos obrigatoriamente no início e ao término. Caso não ocorra ruptura ou "deformação excessiva" do solo, o ensaio será conduzido até que se alcance o dobro da tensão admissível prevista. Atingida a carga máxima, o descarregamento deve ser efetuado em quatro estágios, com leituras dos respectivos deslocamentos. Uma última leitura é realizada dez minutos após o descarregamento total. FELLENIUS (1975) recomenda um tempo de duração do estágio de 15 minutos.

Contudo, essa modalidade de prova de carga não permite o conhecimento do nível de deformação em cada estágio (e no total), se cada carregamento fosse mantido por um período superior ao estabelecido. Entretanto, em decorrência da praticidade que proporciona, este tipo de ensaio possui uma ampla aceitação. FELLENIUS (1975) propõe a troca dos ensaios SML pelos QML, afirmando que a utilização desses últimos pode ser justificada pelo seu baixo custo e reduzido período de execução. 
Ensaio cúclico (Cyclic Load Test - CLT)

Consiste de uma prova de carga na qual se procede o carregamento até $1 / 3$ da tensão admissível prevista, com posterior descarregamento até metade desta tensão, repetindo este ciclo por 20 vezes. Em seguida, a tensão máxima do ciclo anterior é aumentada em $50 \%$, repetindo-se o procedimento. Este tipo de ensaio é bastante empregado em projetos de pavimentos rodoviários e de aeroportos para avaliar o efeito repetitivo das cargas aplicadas pelos veículos sobre o pavimento. O IPT realizou um número razoável dessas provas nos aeroportos de Dracena e Sorocaba, utilizando placa de 0,45 m (IPT, 1991).

Ensaio com taxa de penetração constante (Constant Rate of Penetration TestCRP)

Neste tipo de ensaio, faz-se com que a placa ou sapata penetre a uma velocidade constante pré-determinada, normalmente de $0,5 \mathrm{~mm} / \mathrm{min}$ (FELLENIUS, 1975), medindo-se a força necessária para tanto. O ensaio é levado até serem atingidos recalques da ordem de 50 a $75 \mathrm{~mm}$ ou quando a carga não mais crescer com a penetração. Possui as vantagens de poder ser executado em um curto período (duas a três horas) e de fornecer uma boa definição da curva tensão-recalque resultante. Por outro lado, impõe a utilização de equipamentos especiais, como um macaco hidráulico com fluxo constante de óleo.

\subsection{3 - Interpretação dos resultados}

\section{Determinação da tensão de ruptura}

A ruptura de uma fundação superficial ocorre quando a resistência ao cisalhamento do solo sob a mesma é atingida. TERZAGHI (1943) distingue dois mecanismos de ruptura: a generalizada e a localizada. Posteriormente, VESIC (1963) introduziu o conceito de ruptura por puncionamento. 
Quando há ruptura generalizada, a tensão de ruptura pode ser obtida de forma direta através da curva tensão-recalque. No esquema da Figura 2.1, $\sigma_{r}$ é definida como a tensão para a qual o recalque aumenta indefinidamente sem acréscimo de carga (representada por $\sigma_{b}$ ). Na curva da Figura 2.2, a tensão de ruptura corresponde à máxima tensão mobilizada no ensaio, $\sigma_{a}$.

Não obstante, uma definição nítida da tensão de ruptura não é alcançada em situações nas quais ocorre ruptura localizada, por puncionamento ou obviamente quando o ensaio é finalizado prematuramente. O mais comum é deparar-se com curvas representando situações intermediárias entre aquelas retratadas nas Figuras 2.1 e 2.3. Dessa forma, a tensão de ruptura não é diretamente obtida da curva tensãorecalque, como acontece nos casos precedentes, o que implica a utilização de critérios para a sua determinação. As classificações propostas diferem consideravelmente entre os autores e segundo NIYAMA et al. (1996), os critérios podem ser ordenados em quatro grupos distintos:

a) critérios limitantes do deslocamento total: a tensão de ruptura é fixada em função de um deslocamento pré-determinado. Pode-se destacar os critérios de DAVISSON (1972), da NBR 6122 (1996), de TERZAGHI (1943) e de alguns códigos de obras, como o da cidade norte-americana de Boston, o qual estipula a obtenção da tensão admissível $\sigma_{a}$ da seguinte forma, sendo considerado o menor valor:

- $\sigma_{\mathrm{a}} \leq 10 \mathrm{~mm}$;

- $\sigma_{\mathrm{a}} \leq \frac{25 \mathrm{~mm}}{2}$.

A primeira expressão define a tensão correspondente a um recalque julgado admissível, enquanto que a segunda constitui um critério de ruptura.

b) critérios da deformabilidade limite: a tensão de ruptura corresponde à máxima relação entre a tensão e o deslocamento. Ressalta-se o critério de FULLER \& HOY (1970); 
c) critérios de interseção das fases elástica e plástica: se a curva tensão-recalque é traçada em escala logarítmica, tenderá a duas retas cuja interseção define a carga de ruptura. Destacam-se os métodos de De BEER (1967) e BUTLER \& HOY (1977);

d) critérios matemáticos: consiste na obtenção da tensão de ruptura através do ajuste da curva tensão-recalque com o auxílio de expressões matemáticas. Pode-se salientar os métodos de CHIN (1970), MAZURKIEWICZ (1972) e VAN DER VEEN (1953).

Segundo NIYAMA et al. (1996), apontar o método mais adequado em um determinado caso é impossível, uma vez que todos possuem pontos positivos e negativos. Assim, é recomendado que se efetuem comparações e que se tenha bom senso na escolha do valor de $\sigma_{\mathrm{r}}$.

\section{Estimativas de parâmetros de resistência e de deformação}

Segundo ROCHA $\mathrm{F}^{0}$ (1985), as informações obtidas a partir de uma prova de carga podem ser utilizadas de duas maneiras distintas: a) para verificar o comportamento da fundação sob uma solicitação e b) como ensaio in situ. A primeira finalidade serve para a comparação direta entre o valor do recalque medido e o do recalque estabelecido pelo projeto, bem como para a verificação da capacidade de carga do elemento de fundação. Já na segunda abordagem, o autor considera que se deve lançar mão de expressões fornecidas tanto pela Teoria da Elasticidade quanto pela Teoria da Plasticidade para obter parâmetros elásticos (módulo de Young $E$ e coeficiente de Poisson v) e de resistência ao cisalhamento (coesão $c$ e ângulo de atrito $\phi)$ através dos resultados do ensaio de placa.

Pode-se utilizar provas de carga em placa para a obtenção de $E$ e v procedendo-se a retroanálises através de fórmulas da Teoria da Elasticidade para cálculo de recalque, como por exemplo: 
$\mathrm{s}=\sigma \mathrm{B} \frac{1-v^{2}}{\mathrm{E}} \mathrm{I}_{\mathrm{s}} \mathrm{I}_{\mathrm{d}} \mathrm{I}_{\mathrm{h}}$

onde:

$\mathrm{s}$ - recalque;

$\sigma$ - tensão média aplicada;

B - menor dimensão da sapata;

$I_{S}$ - fator de forma da sapata e de sua rigidez;

$I_{d}$ - fator de profundidade/embutimento;

$\mathrm{I}_{\mathrm{h}}$ - fator de espessura da camada compressível.

Com a utilização da expressão 2.1, apenas um parâmetro pode ser obtido, uma vez conhecido s. No caso de fundação, a associação entre deslocamentos e esforços exige no mínimo dois parâmetros elásticos. Entretanto, no caso em que o comportamento do solo é similar ao de um meio homogêneo e isotrópico, uma vez admitida a hipótese de linearidade, a influência do coeficiente de Poisson não é significativa, justificando, por conseguinte, um valor aproximado (ROCHA $\mathrm{F}^{\mathrm{O}}$, 1985).

POULOS \& DAVIS (1973) apresentam uma vasta coletânea de soluções de problemas da esfera da Mecânica dos Solos, da Mecânica das Rochas e da Engenharia de Fundações através da Teoria da Elasticidade. Apesar da grande maioria ter sido desenvolvida considerando maciço homogêneo e isotrópico, algumas importantes soluções incluídas referem-se a meios elásticos não-homogêneos e anisotrópicos.

A solução reproduzida a seguir é referente ao recalque produzido por uma tensão $\sigma$ atuante sobre uma área circular de raio $R$, na superfície de um maciço semiinfinito (Figura 2.4a). O coeficiente de Poisson $v$ é considerado constante com a profundidade, enquanto que o módulo cisalhante $G$ aumenta de acordo com a expressão (2.2). A Figura 2.4b ilustra a variação de $G$ com a profundidade.

$\mathrm{G}(\mathrm{z})=\mathrm{G}(0)+\mathrm{mz}$ 


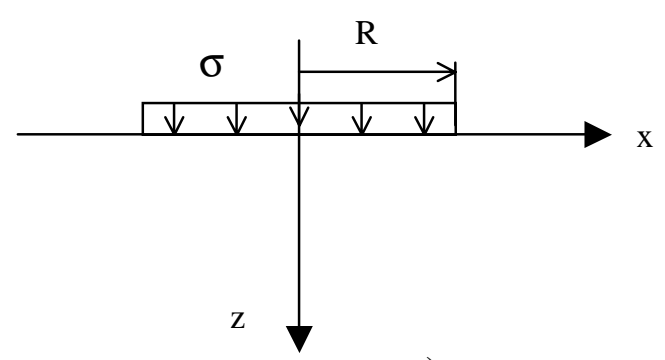

a)

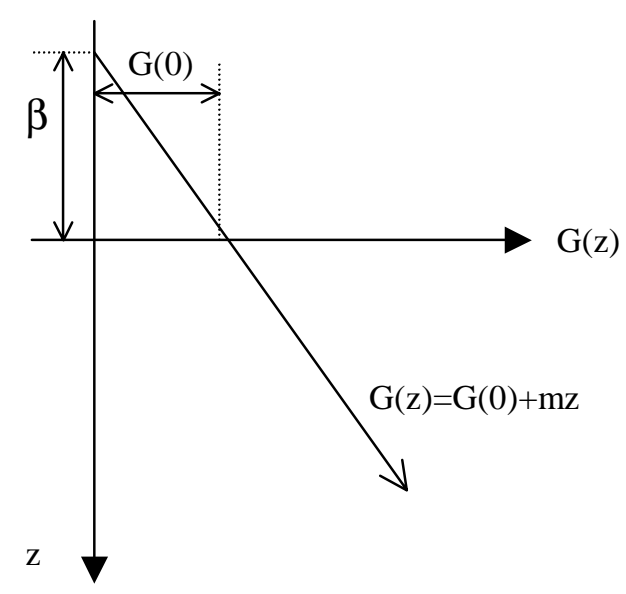

b)

FIGURA 2.4 - a) carregamento sobre uma área circular num maciço semi-infinito;

b) variação do módulo cisalhante com a profundidade (POULOS \& DAVIS, 1973)

A Figura 2.5 mostra a variação do recalque ocorrido no centro da placa com o parâmetro $\beta$ (definido na Figura 2.4b), para coeficientes de Poisson iguais a 0;0,33 e 0,5. Através deste gráfico, é possível estimar $\mathrm{G}(0)$ uma vez conhecidos os parâmetros $\beta, \sigma$ e R. A expressão (2.2) permite a obtenção de $G$ numa profundidade z qualquer.

MELLO \& CEPOLLINA (1978) realizaram provas de carga em placa com a utilização de medidores de recalques profundos, localizados dentro do bulbo de tensões gerado pela placa, a fim de se estimar o módulo de deformabilidade do solo. Para tanto foi utilizada a seguinte expressão:

$$
\mathrm{E}=\frac{\sigma \mathrm{R}}{\mathrm{s}}\left[\left(1-\mathrm{v}^{2}\right)\left(\frac{\pi}{2}-\operatorname{arctg}(\mathrm{z} / \mathrm{R})\right)+\frac{\mathrm{z} / \mathrm{R}(1-\mathrm{v})}{1+(\mathrm{z} / \mathrm{R})^{2}}\right]
$$


onde:

$\sigma$ - tensão vertical aplicada à placa;

$\mathrm{R}$ - raio da placa;

$v$ - coeficiente de Poisson;

$\mathrm{z}$ - Profundidade na qual a medição é realizada.

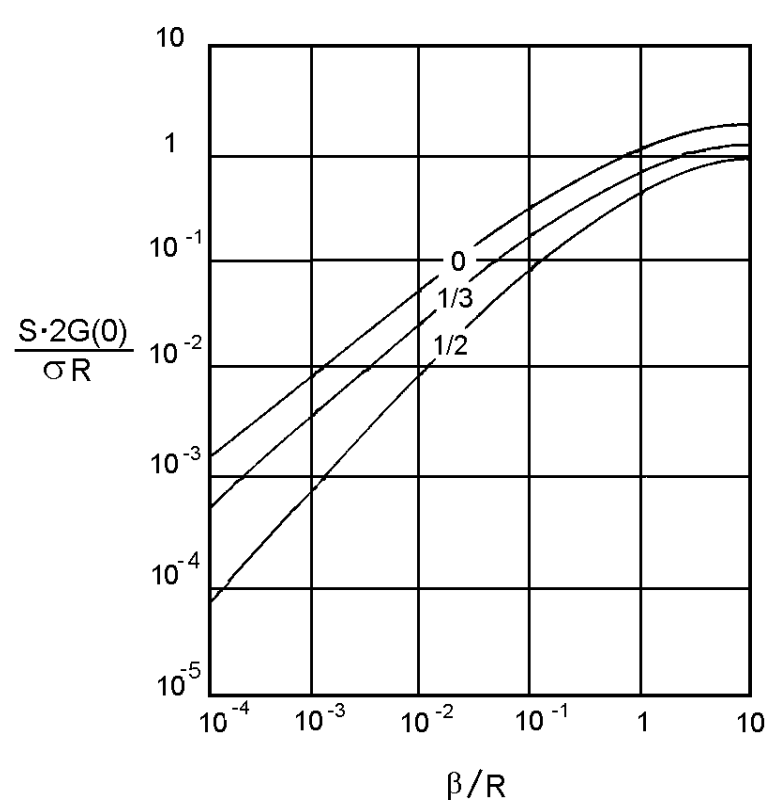

FIGURA 2.5 - Recalque no centro de uma área circular (POULOS \& DAVIS, 1973)

VELLOSO et al. (1978) comparam módulos de deformabilidade calculados a partir da equação 2.1 com obtidos em ensaios laboratoriais, observando que estes últimos apresentam-se em média seis vezes menores. Os autores concluem que as diferenças podem ser atribuídas: a) ao alívio de tensões confinantes e amolgamentos inerentes aos processos de amostragem do solo e b) aos efeitos de dimensão e de volume do solo envolvidos nos ensaios de laboratório e nas provas de carga no campo. Em procedimento semelhante, MARTINS \& MARTINS (1997) obtiveram módulos provenientes de cinco provas de carga direta com placa de 0,60 $\mathrm{m}$ de diâmetro bastante superiores aos de ensaios laboratoriais. 
Parâmetros de resistência do solo podem ser obtidos através de provas de carga direta procedendo-se retroanálises via fórmulas de capacidade de carga, como por exemplo as propostas por TERZAGHI (1943), MEYERHOF (1951), HANSEN (1970), entre outras.

Pode-se também realizar retroanálises de uma forma "mais precisa", tanto para obtenção de parâmetros de resistência quanto de deformação, com o auxílio de métodos numéricos.

\subsection{4 - Considerações sobre a influência da dimensão da placa nos resultados de recalque}

De modo a ilustrar o efeito causado pela dimensão da placa nos resultados de recalque numa prova de carga direta, REZNIK (1993) reporta que resultados de diversos autores em diferentes tipos de solo convergem para uma relação do tipo mostrada na Figura 2.6.

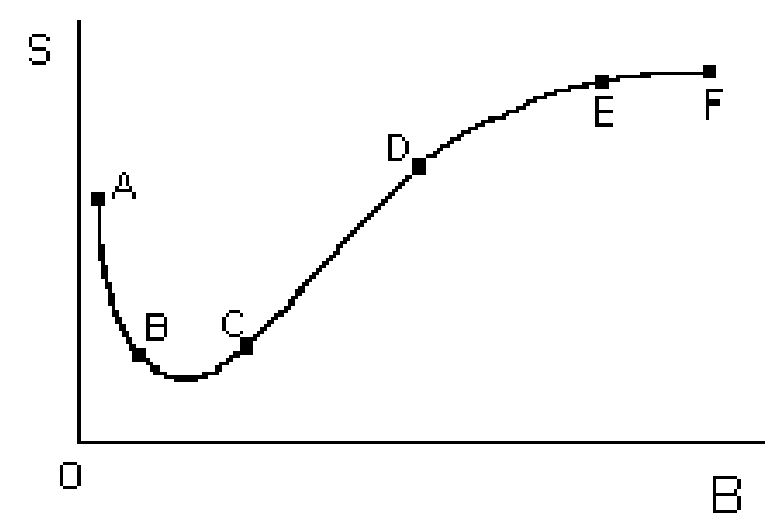

FIGURA 2.6 - Relação entre recalque $s$ e largura (ou diâmetro) $B$ de sapatas e placas rígidas para uma tensão constante aplicada (GORBONOV-POSSADOV \& DAVIDOV, 1973)

Geralmente, a placa utilizada em uma prova de carga possui dimensões inferiores à da futura sapata. Dessa forma, como mostra a Figura 2.6, faz-se necessário realizar uma extrapolação dos resultados de recalque da prova de carga 
em placa (modelo) para uma sapata de fundação (protótipo). ALBIEIRO et al. (1993) afirmam que, de um modo geral, o emprego de provas de carga em placa é a melhor alternativa para previsão de recalques, desde que se utilize adequada correlação entre o modelo e o protótipo. Segundo DÉCOURT (1991), o problema mais importante que o projetista de fundações (rasas) enfrenta diz respeito à extrapolação dos resultados obtidos de provas de carga em placas para o tamanho real da fundação.

No caso de se deparar com um depósito de argila, é comum admitir $E$ e v constantes com a profundidade, de modo a permitir que a correlação entre o recalque de uma placa e de uma fundação superficial real nesse tipo de solo seja determinada com o auxílio de formulações da Teoria da Elasticidade, como:

$\mathrm{s}_{\mathrm{B}}=\mathrm{s}_{\mathrm{b}} \frac{\mathrm{B}}{\mathrm{b}} \frac{\mathrm{I}_{\mathrm{S}, \mathrm{B}}}{\mathrm{I}_{\mathrm{S}, \mathrm{b}}}$

onde:

B - menor dimensão da base do protótipo;

b - menor dimensão da base do modelo;

$\mathrm{S}_{\mathrm{B}}-$ recalque da sapata;

$\mathrm{S}_{\mathrm{b}}$ - recalque da placa;

$\mathrm{I}_{\mathrm{S}, \mathrm{B}}$ e $\mathrm{I}_{\mathrm{S}, \mathrm{b}}$ - Fatores de forma da sapata e da placa, respectivamente.

No entanto, MELLO \& CEPOLINA (1978) ressaltam que para "argilas puras", apesar de ter sido sempre teoricamente admitida a relação modelo-protótipo diretamente proporcional, tal estado ideal parece não ocorrer jamais em condições reais. Na realidade, nesse tipo de solo há um aumento da resistência e do módulo de "compressibilidade" com a profundidade.

Em solos arenosos, o módulo de deformabilidade $E$ não é constante com a profundidade, variando, entre outros fatores, com a tensão confinante e com a largura $\mathrm{B}$ da fundação, de modo que uma relação linear entre esta e o recalque $s$ não é adequada. Para mesmos valores de carregamento, TERZAGHI \& PECK (1967) propõem a seguinte expressão que relaciona o recalque $s_{B}$ de uma sapata de largura 
$\mathrm{B}$, em metros, e o recalque $\mathrm{s}_{\mathrm{b}}$ gerado por uma placa quadrada, de $0,3 \mathrm{~m}$ de lado assente em uma camada de areia:

$$
\frac{\mathrm{s}_{\mathrm{B}}}{\mathrm{s}_{\mathrm{b}}}=\left(\frac{2 \mathrm{~B}}{\mathrm{~B}+0,3}\right)^{2}
$$

Substituindo valores para B, observa-se que a expressão 2.5 conduz a um valor máximo igual a 4 . A partir de estudos de registros de casos, BJERRUM \& EGGESTAD (1963) concluíram que a expressão 2.5 não é confiável, podendo haver uma dispersão considerável na correlação entre o recalque e a dimensão da área carregada e que podem existir coeficientes maiores que 4. Os autores revelaram ainda que a relação $\left(\mathrm{s}_{\mathrm{B}} / \mathrm{s}_{\mathrm{b}}\right)$ não varia somente com $\mathrm{B}$, dependendo também da compacidade da areia, como mostra a Figura 2.7.

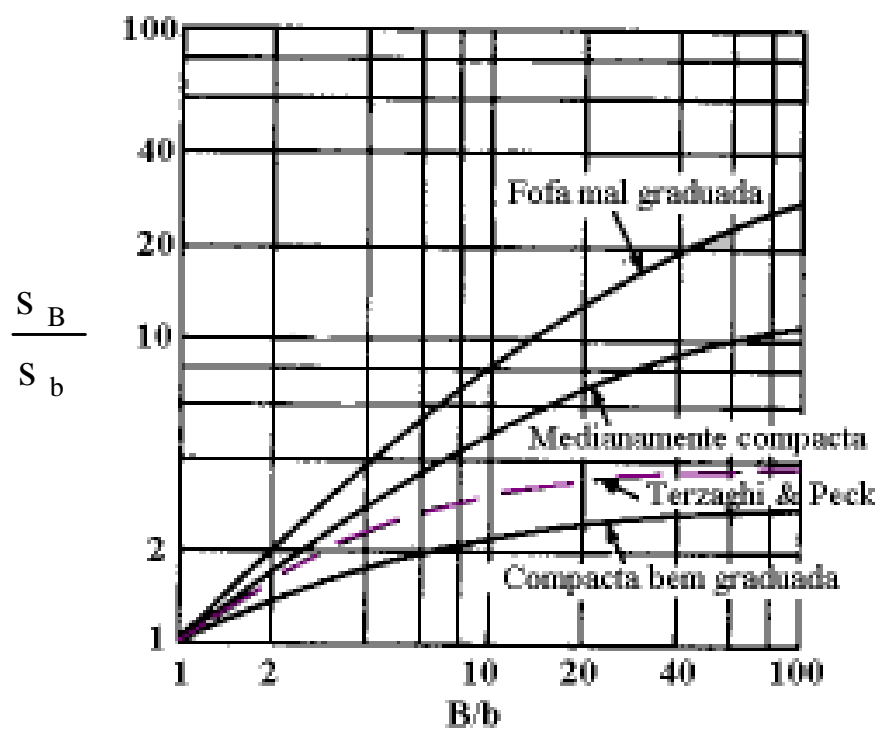

FIGURA 2.7 - Relação entre o coeficiente de recalque e a razão tamanho da placa/tamanho da fundação segundo TERZAGHI \& PECK (1948) e BJERRUM \& EGGESTAD (1963) 
Posteriormente, outros autores também propuseram expressões para correlacionar os resultados de recalques do modelo com os do protótipo. BAZARAA $^{2}$ apud ROCHA $F^{o}$ (1985) propõe a seguinte relação empírica entre o recalque $\left(\mathrm{s}_{\mathrm{B}}\right)$ de uma sapata com menor dimensão $\mathrm{B}$ e o recalque $\left(\mathrm{s}_{\mathrm{b}}\right)$ de uma placa de menor dimensão b:

$$
\frac{\mathrm{s}_{\mathrm{B}}}{\mathrm{s}_{\mathrm{b}}}=\left(\frac{2,5 \mathrm{~B}}{\mathrm{~B}+1,5 \mathrm{~b}}\right)^{2}
$$

Baseado nos trabalhos de TERZAGHI \& PECK (1967), SOWERS (1962) sugere a seguinte relação empírica entre o recalque de uma placa e o de uma fundação real:

$$
\frac{s_{B}}{s_{b}}=\left(\frac{B(b+0,30)}{b(B+0,30)}\right)^{2}
$$

No entanto, segundo DÉCOURT \& QUARESMA Fº (1996), não há a necessidade de extrapolação de resultados em provas de carga direta, uma vez que a interferência do efeito escala não mais existirá se os recalques forem normalizados pelo lado ou diâmetro da placa e as tensões, pela tensão correspondente à ruptura convencional. Para corroborar sua proposição, os autores comparam resultados de ensaios conduzidos com a utilização de placas de $127 \mathrm{~mm}$ de diâmetro, denominadas "mini-placas" com resultados de ensaios executados em placas de 0,8 m de diâmetro. Para a execução do ensaio na placa de dimensão reduzida, utilizava-se furo de aproximadamente $150 \mathrm{~mm}$ de diâmetro, aberto com a utilização de equipamentos de sondagem a percussão. Na transmissão da carga, era empregado um tubo de $635 \mathrm{~mm}$ de diâmetro em cuja extremidade inferior encontrava-se soldada à placa. 
CONSOLI et al. (1998) chegam a conclusões semelhantes às de DÉCOURT \& QUARESMA F $^{0}$ (1996) em ensaios em placas com diâmetros de 0,30; 0,45 e 0,60 $\mathrm{m}$ e em sapatas quadradas de 0,$4 ; 0,7$ e $1,0 \mathrm{~m}$ de largura, conduzidos em um solo residual cimentado e sem coesão. A Figura 2.8 apresenta os resultados obtidos, juntamente com outros resultados reproduzidos na literatura, de modo a confirmar tal premissa. Segundo os autores, os resultados de uma prova de carga em placa devem ser independentes do tamanho da placa ensaiada sempre que o substrato abaixo da fundação for considerado homogêneo e isotrópico.

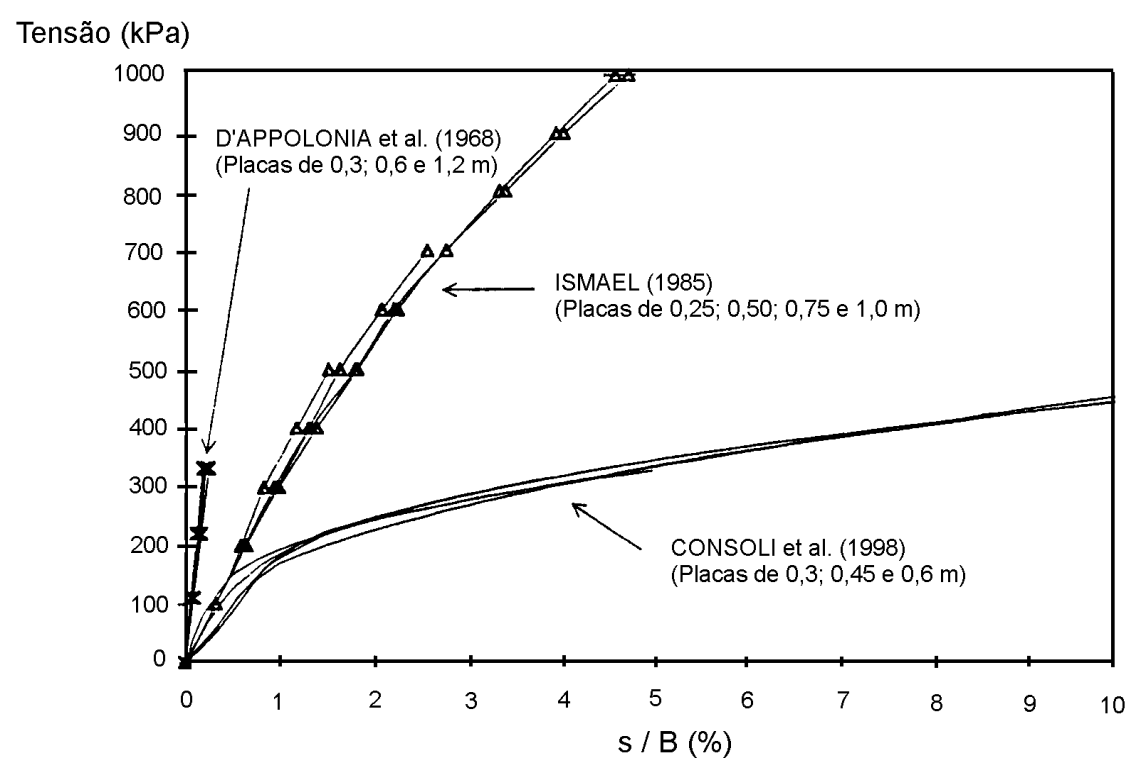

FIGURA 2.8 - Ensaios de placa em solo homogêneo, sem coesão e cimentado em termos de tensão versus recalque normalizado (CONSOLI et al. , 1998)

\subsection{5 - Verificação do colapso do solo através de provas de carga em placa}

Algumas regiões brasileiras são cobertas por solos porosos de origem coluvionar, aluvionar ou de alteração de rocha. O clima tropical, caracterizado pela alternância de estações secas e chuvosas, aliado a uma situação de boa drenagem, propiciou ao solo um processo de laterização. Em outras palavras, criou-se uma estrutura porosa e não saturada, com alto índice de vazios e um baixo teor de 
umidade, menor que o necessário para sua completa saturação, cujas condições são básicas para a ocorrência do fenômeno do colapso.

O conceito de "colapso" possui um significado bastante abrangente (GRIGORIAN, 1997), não existindo ainda uma definição unanimemente aceita. De uma maneira sucinta, o colapso do solo pode ser definido como uma redução brusca do índice de vazios, após ocorrido um aumento do teor de umidade. Em diversos tipos de solo, o colapso é desencadeado quando o solo é submetido a um processo de umedecimento. Já em outros tipos, além desta condição, é necessário que o solo esteja solicitado por um determinado carregamento para que haja a manifestação do fenômeno.

O comportamento dos solos colapsíveis tem causado danos a estruturas apoiadas em fundações superficiais e profundas, de modo que não é raro observar trincas nas paredes de casas e prédios. Dessa forma, surgiu a necessidade de levar a colapsibilidade em consideração nos projetos de fundação. Neste sentido, a prova de carga em placa tem sido empregada como ferramenta para o estudo da colapsibilidade do solo e sua influência na capacidade de carga e nos recalques. Alguns trabalhos concernentes ao estudo da colapsibilidade do solo do interior do Estado de São Paulo e de outras regiões brasileiras onde é constatada a presença de tal tipo de solo, através de ensaios de placa, são detalhados a seguir.

CINTRA et al. (1986) realizaram ensaios em modelos, utilizando amostras indeformadas e compactadas, ensaiadas com placas de $30 \times 60 \mathrm{~mm}^{2}$. Uma das amostras foi ensaiada no teor de umidade natural até a estabilização dos recalques na tensão de $80 \mathrm{kPa}$, sendo então inundada sob carga constante. Outras duas amostras foram compactadas, em camadas sucessivas, com 80 a $90 \%$ do peso específico seco máximo e então ensaiadas. Como resultado, os autores observaram uma sensível influência da compactação do solo na redução dos recalques devido ao colapso. 
FERREIRA et al. (1990) realizaram seis provas de carga sobre placa rígida circular de 0,80 m de diâmetro, como parte de um programa de pesquisas elaborado pelo Companhia Energética de São Paulo. No solo em questão, foram ensaiados os horizontes de 1, 2 e $4 \mathrm{~m}$, sendo executadas duas provas de carga em cada profundidade, uma sem inundação e outra com inundação após carregamento parcial. A Tabela 2.1 mostra o colapso registrado nas provas de carga inundadas, em cada profundidade mencionada, bem como os valores de teor de umidade do solo correspondentes a cada ensaio (antes da inundação). Segundo os autores, o colapso à profundidade de $2 \mathrm{~m}$ foi mais pronunciado porque o solo possuía um menor teor de umidade em comparação com os verificados às profundidades de 1 e 4 m. Foi concluído então que o colapso do solo é governado pelo teor de umidade. Caso a tensão de inundação e a profundidade não tivessem sido variadas, possivelmente conclusões mais sólidas com respeito à influência do teor de umidade na magnitude do colapso do solo poderiam ter sido alcançadas. Contudo, convém salientar que este trabalho é um dos primeiros na literatura a atentar para a influência do teor de umidade nos resultados de provas de carga.

TABELA 2.1 - Resultados de provas de carga direta realizadas por FERREIRA et al. (1990)

\begin{tabular}{c|c|c|c}
\hline Prof. $(\mathrm{m})$ & Tensão de inundação $(\mathrm{kPa})$ & Colapso $(\mathrm{mm})$ & Teor de umidade $(\%)$ \\
\hline 1,0 & 60 & 36,6 & 7,8 \\
2,0 & 100 & 71,1 & 6,9 \\
4,0 & 125 & 22,9 & 9,5 \\
\hline
\end{tabular}

CARVALHO \& SOUZA (1990) realizaram duas provas de carga direta a uma profundidade de 0,60 m no Campus da Faculdade de Engenharia da UNESP de Ilha Solteira - SP. A primeira prova foi realizada com o solo no teor de umidade natural. A outra foi conduzida até um valor correspondente a 1/3 da carga máxima obtida no ensaio anterior, quando então, estabilizados os recalques, iniciou-se a colocação de água no solo adjacente à placa. Os resultados mostraram uma ocorrência instantânea de recalques provocados pela presença da água, caracterizando o colapso do solo (Figura 2.9). 


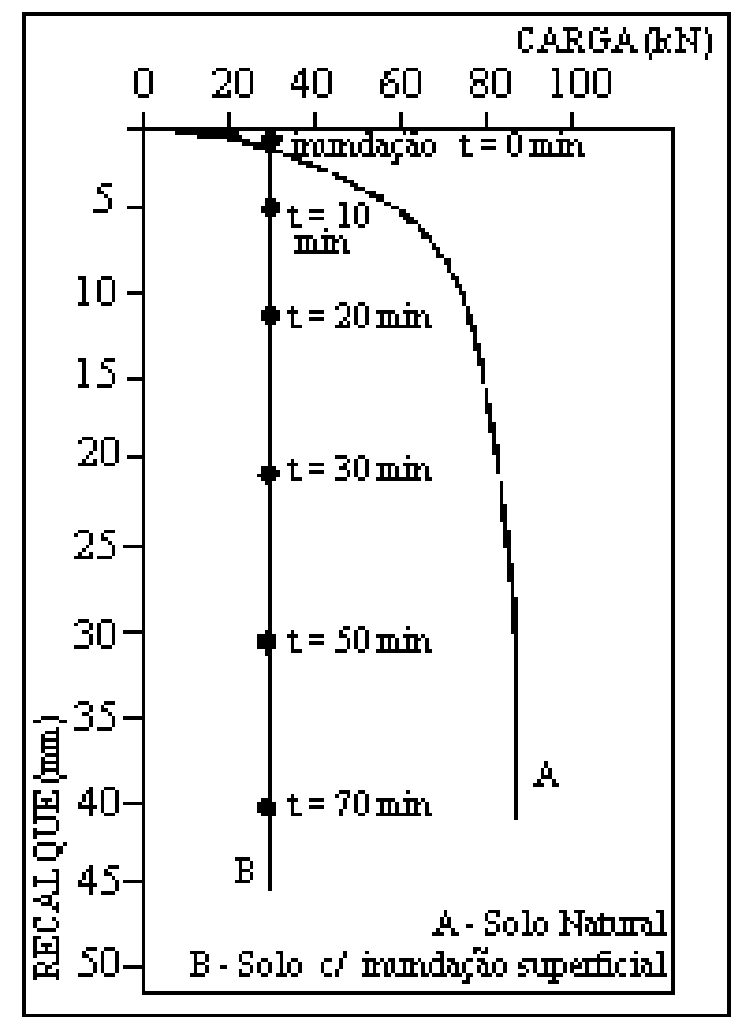

FIGURA 2.9 - Provas de carga em placa na umidade natural e com inundação

(CARVALHO \& SOUZA, 1990)

AGNELLI (1992) estudou a colapsibilidade do solo de Bauru - SP através da realização de 12 provas de carga em placa no campus da UNESP, na mesma cidade, às profundidades de 1 e $2 \mathrm{~m}$. Seis ensaios foram conduzidos com o solo não inundado, sendo os outros seis sob inundação. Foram adotadas tensões de inundação correspondentes a 24,48 e $72 \%$ da tensão que causaria um recalque de $25 \mathrm{~mm}$ nas provas de carga sem inundação. Através desta pesquisa, pôde-se confirmar o caráter colapsível do solo superficial. Os resultados obtidos também sugerem um aumento dos recalques por colapso com o aumento da tensão de inundação. A Figura 2.10 resume os resultados obtidos para a profundidade de $2 \mathrm{~m}$. 


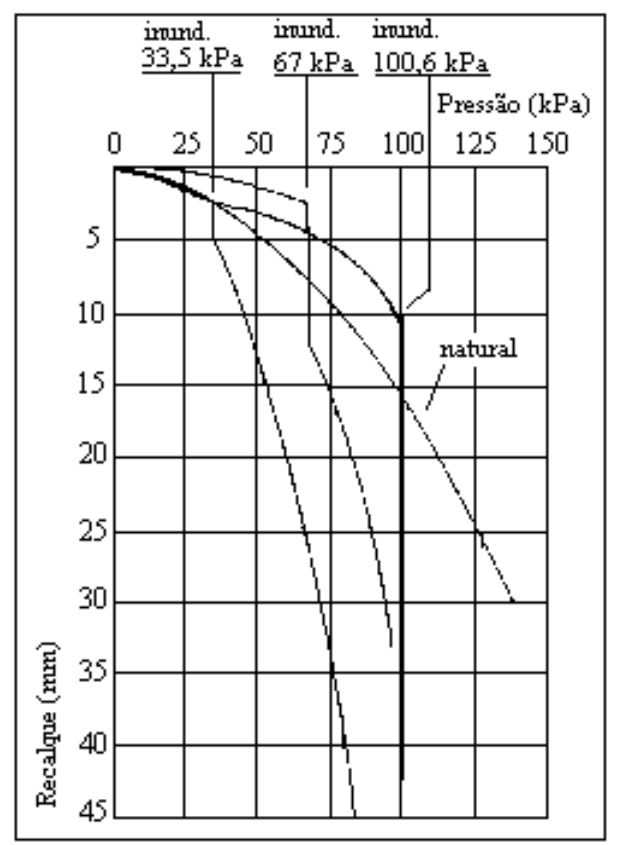

FIGURA 2.10 - Resultados de provas de carga conduzidas na prof. de $2 \mathrm{~m}$

(AGNELLI, 1992)

SOUZA \& CINTRA (1994) executaram provas de carga em placa de 0,80 m de diâmetro e em sapata corrida sobre o solo colapsível de Ilha Solteira - SP, à cota de $-0,70 \mathrm{~m}$. Duas sapatas foram ensaiadas, sendo a primeira em "solo natural" e a segunda sobre solo compactado em seis camadas de $0,10 \mathrm{~m}$, com uma energia de compactação equivalente a 8,2 \% da energia de Proctor Normal. Em ambos os casos, as sapatas foram carregadas até $120 \mathrm{kPa}$, sendo em seguida o solo inundado. Confrontando-se os resultados, foi verificada uma redução de recalques por colapso em torno de $79 \%$ em virtude da compactação do solo. Os ensaios de placa, em número de quatro, foram executados da seguinte forma: em solo natural; em solo compactado; em solo natural e inundado a $60 \mathrm{kPa}$; e em solo compactado e inundado a $60 \mathrm{kPa}$. Para este caso, ocorreu uma diminuição de cerca de $86 \%$ nos recalques por colapso.

TEIXEIRA et al. (1996) realizaram 13 provas de carga rápidas em placas com dimensões e formas variadas e em profundidades entre 0,5 e 6,0 m. Os ensaios foram executados no campo experimental da Universidade de Lavras - MG, o qual possui um solo representativo do solo da região, com fortes evidências de 
comportamento colapsível. Uma das provas de carga, realizada com inundação do solo na tensão de $100 \mathrm{kPa}$, demonstrou perda de pelo menos $50 \%$ da capacidade de carga após a inundação.

CONCIANI (1997) estudou o colapso do solo através de provas de carga em placa de 0,80 m de diâmetro executadas na "umidade natural" e com inundação da cava em diferentes tensões, no Estado do Mato Grosso. No total, foram realizados oito ensaios, sendo metade executada no município de Rondonópolis, à profundidade de 0,5 m e a outra metade, em Campo Novo do Parecis, a $1 \mathrm{~m}$ de profundidade. A sucção do solo foi monitorada através de tensiômetros instalados no fundo da cava, ao redor da placa.

Na Tabela 2.2 é reproduzida a tensão na qual o solo sofreu inundação, juntamente com a magnitude dos recalques antes e após a inundação. Os valores médios de sucção medidos nas provas de carga até a profundidade igual ao diâmetro da placa foram inseridos na mesma tabela.

TABELA 2.2 - Recalques medidos nas provas de carga realizadas por CONCIANI (1997) e valores médios de sucção

\begin{tabular}{c|c|c|c|c|c}
\hline Local & Ensaio & $\begin{array}{c}\text { Tensão de } \\
\text { inundação } \\
(\mathrm{kPa})\end{array}$ & $\begin{array}{c}\text { Recalque antes } \\
\text { da inundação } \\
(\mathrm{mm})\end{array}$ & $\begin{array}{c}\text { Recalque após } \\
\text { a inundação } \\
(\mathrm{mm})\end{array}$ & $\begin{array}{c}\text { Sucção } \\
(\mathrm{kPa})\end{array}$ \\
\hline \multirow{3}{*}{ Campo Novo } & 1 & - & 26,6 & - & 21 \\
do Parecis & $3 *$ & 36 & 2,0 & 48,1 & 23 \\
& 4 & 54 & 5,6 & 49,4 & 22 \\
\hline \multirow{3}{*}{ Rondonópolis } & 1 & 18 & 1,1 & 49,2 & 14 \\
& $2^{*}$ & 45 & 9,2 & - & 15 \\
& 4 & 67 & 12,1 & 50,3 & 17 \\
& 20 & 10,9 & 95,4 & 24 \\
\hline
\end{tabular}

Nota: 1) O recalque após a inundação está acumulado com o inicial

2) * - recalque não medido até a estabilização por falta de curso do macaco ou do deflectômetro

Os resultados não permitem uma conclusão clara a respeito da variação dos recalques por colapso com a tensão de inundação em virtude da impossibilidade, ocorrida em três dos ensaios, de medição dos recalques após a inundação até a 
estabilização. Entretanto, foi verificado um aumento do potencial de colapso do solo CP (calculado segundo a proposta de REZNIK, 1993) com o aumento da tensão de inundação, para os resultados de Campo Novo do Parecis. Para os resultados de Rondonópolis, $C P$ revelou-se praticamente o mesmo para as tensões de 20 e $45 \mathrm{kPa}$. Contudo, seu valor para a tensão de $67 \mathrm{kPa}$ foi quase o dobro dos correspondentes às outras duas tensões averiguadas. A Tabela 2.3 exibe os resultados.

TABELA 2.3 - Valores do potencial de colapso calculados com base na proposta de REZNIK (1993) (CONCIANI, 1997)

\begin{tabular}{c|c|c|c}
\hline Local & Furo & Tensão de inundação $(\mathrm{kPa})$ & $\mathrm{CP}(\%)$ \\
\hline Campo Novo & 2 & 36 & 29,8 \\
do Parecis & 3 & 54 & 35,2 \\
& 4 & 18 & 4,5 \\
\hline \multirow{3}{*}{ Rondonópolis } & 2 & 45 & 30,4 \\
& 3 & 67 & 67,6 \\
& 4 & 20 & 32,8 \\
\hline
\end{tabular}

Uma vez que a inundação foi realizada nos ensaios em diferentes tensões, os resultados apresentados não permitem uma averiguação da influência da sucção matricial sobre os recalques por colapso. Por outro lado, os níveis de sucção medidos nos ensaios são bastante próximos, fator que também viria a dificultar análises desta natureza, caso fossem possíveis.

AGNELLI (1997) avaliou o colapso do solo mediante a inundação de líquidos de diferentes composições, através de provas de carga em placa, em pesquisa desenvolvida no campo experimental da UNESP de Bauru - SP. Foram realizadas 16 provas de carga direta do tipo QML, às profundidades de 1, 2, 3 e 4 m, não inundadas e com inundação sob carregamentos distintos. Como resultado, concluiu-se que a deformação do solo depende, dentre outros fatores, da composição química e do pH do líquido inundante. A Figura 2.11 apresenta o efeito da inundação do solo por água potável e hidróxido de sódio na provas de carga, comparando com um ensaio na "umidade natural". 


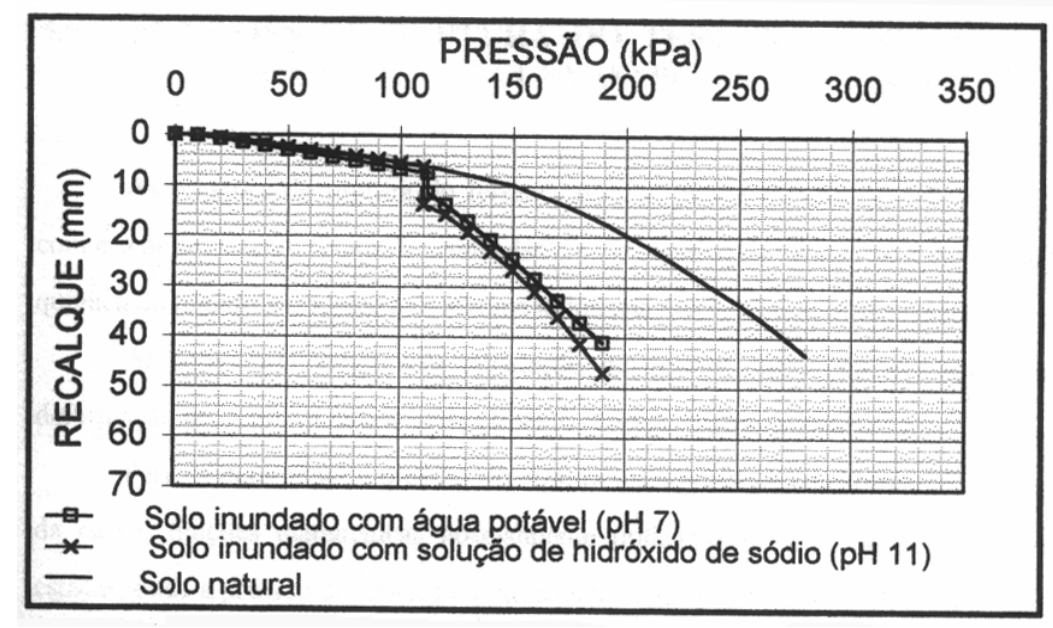

FIGURA 2.11 - Resultados de provas de carga em placa com diferentes líquidos de inundação (AGNELLI, 1997)

FERREIRA et al. (1998) realizaram provas de carga em placas de 0,3 e 0,4 m de diâmetro nos municípios de Petrolina, Santa Maria da Boa Vista e Petrolândia, no estado de Pernambuco, locais onde o solo é considerado colapsível. Foram executados ensaios em profundidades entre 0,5 e $1 \mathrm{~m}$, com o solo no "teor de umidade natural", com inundação prévia por um determinado período antes do ensaio e com inundação numa determinada tensão durante o ensaio. Foi também utilizado um equipamento de campo denominado "Expansocolapsômetro", o qual permite comparar resultados de ensaios in situ com resultados de ensaios oedométricos simples e duplos, uma vez que possibilita transformar os recalques obtidos em deformações.

A Figura 2.12a mostra o colapso ocorrido nos ensaios de placa, através da comparação da curva de um ensaio não inundado com a de um ensaio com inundação prévia. A Figura 2.12b permite confrontar um ensaio não inundado com dois ensaios inundados nas tensões de 10 e $80 \mathrm{kPa}$. Neste caso, foram observados recalques por colapso de 0,55 e $2,80 \mathrm{~mm}$, respectivamente. 

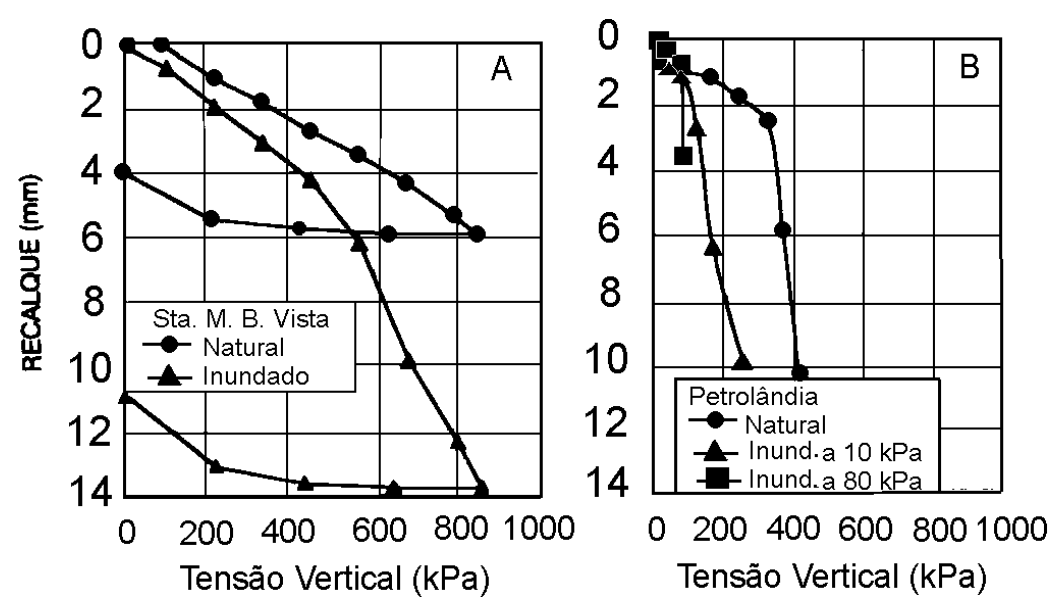

FIGURA 2.12 - Resultados de ensaios de placa realizados por FERREIRA et al. (1998).

A - Sta. Maria da Boa Vista. B - Petrolândia

O teor de umidade do solo era obtido antes e após o término da prova de carga (ou do ensaio com o Expansocolapsômetro), com o objetivo de observar a profundidade atingida pela frente de umedecimento do solo ao final do ensaio. Nas provas de carga, foi verificada uma profundidade de influência entre 2 a 2,5 vezes o diâmetro da placa. Nos ensaios com o Expansocolapsômetro, a profundidade encontrada foi $2,75 \mathrm{~B}$.

\subsection{6 -Considerações sobre a influência da sucção}

Como mencionado no início do capítulo, a realização de provas de carga direta consiste em uma prática bastante antiga na Engenharia Geotécnica. Da mesma forma, a estimativa de capacidade de carga e de recalques constituem dois dos mais comuns exercícios da área, havendo disponível na literatura uma vasta gama de métodos teóricos, semi-empíricos e empíricos para tanto. Não obstante, poucos são os trabalhos que se preocuparam em levar em consideração e a estudar a influência da sucção nos resultados.

Inicialmente, a maioria das pesquisas em solos não saturados referia-se ao fluxo da água na zona de poro-pressões negativas, ou seja, ao fenômeno da 
capilaridade (FREDLUND \& RAHARDJO, 1993). Por isso, em muitas das pesquisas na área da Engenharia de Fundações que levam em consideração o estado de saturação do solo, é observado que os resultados obtidos estão sempre relacionados à posição do lençol freático no maciço. Somente nos últimos anos, com o avanço da mecânica dos solos não saturados, o problema vem passando a ser analisado em função da sucção matricial.

MEYERHOF (1955) desenvolveu uma teoria para estimativa da capacidade de carga de fundação superficial considerando situações de submersão total e parcial do maciço. O estado de saturação do solo é levado em conta através do peso específico do solo. No caso de submersão total, o nível da água subterrânea $z_{w}$ encontra-se à superfície do terreno, sendo utilizado $\gamma_{\text {sub }}$ para a estimativa da capacidade de carga. Na submersão parcial, o nível do lençol situa-se entre a cota de apoio da fundação e a cota inferior da superfície de ruptura $z_{o}$, como mostra a Figura 2.13. Dessa forma, o valor do peso específico a ser utilizado estará compreendido entre $\gamma_{\text {sub }}$ e $\gamma$. Considerando um solo não coesivo e sem sobrecarga, a capacidade de carga neste caso pode ser estimada através da expressão 2.8 .

$\mathrm{q}_{\mathrm{u}}=\left[\gamma_{\text {sub }}+\mathrm{F}\left(\gamma-\gamma_{\text {sub }}\right)\right] \frac{\mathrm{B}}{2} \mathrm{~N}_{\gamma}$

onde:

$\gamma$-peso específico "natural";

F - fator que varia de zero para maciço totalmente submerso até um, quando o lençol freático está abaixo da cota inferior da zona de ruptura.

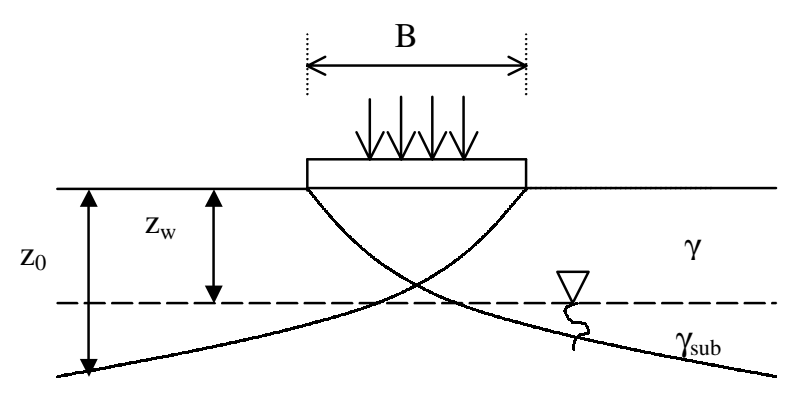


MEYERHOF (1955) também realizou ensaios em modelos de sapatas de 25 mm de largura em areia, variando o nível do lençol freático. Os resultados apontaram um crescimento linear da tensão de ruptura com a profundidade do lençol até um valor máximo, além do qual a mesma permanece constante. $\mathrm{O}$ autor atribui a este fato o aumento do peso específico e da coesão do solo, sendo esta última proveniente do efeito das pressões negativas da água. A Figura 2.14 exibe o aumento da tensão de ruptura com o aumento da profundidade do lençol freático.

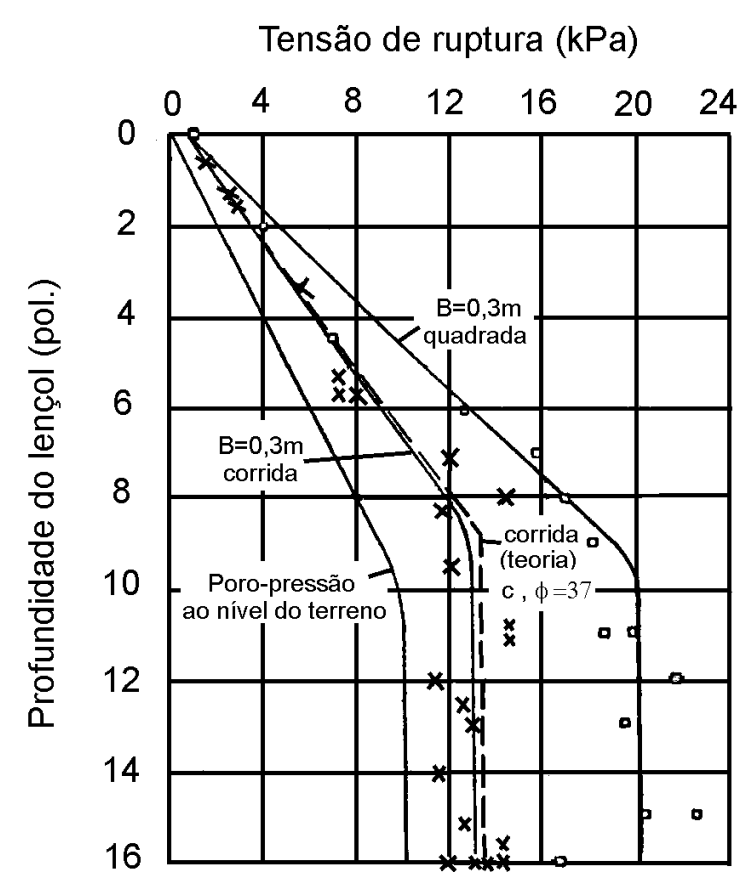

FIGURA 2.14 - Capacidade de carga de sapatas em modelo na superfície de uma areia parcialmente submersa (MEYERHOF, 1955)

AMAR et al. (1987) realizaram provas de carga in situ sobre um solo siltoso, com o lençol freático variando de 0 a $3 \mathrm{~m}$ de profundidade. Foram executados ensaios de curta e de longa duração. Os ensaios de curta duração referiam-se a provas de carga com sapatas quadradas de $1 \mathrm{~m}$ de lado na superfície do terreno. Por sua vez, os ensaios de longa duração diziam respeito à monitoração dos recalques de uma sapata submetida a um carregamento constante, quando ocorre variação do nível do lençol. Para estes ensaios, foi utilizada uma sapata quadrada de $1 \mathrm{~m}$ de lado, assente a $0,5 \mathrm{~m}$ de profundidade. 
Os ensaios de curta duração foram realizados sob duas condições distintas: com o solo apresentando um grau de saturação de $90 \%$, quando o lençol estava situado a menos de $1 \mathrm{~m}$ de profundidade e de $75 \%$, quando o nível d'água encontrava-se em torno de $2,5 \mathrm{~m}$ de profundidade. A Tabela 2.4 exibe os resultados obtidos para as duas situações. Pode-se observar a influência exercida pelo teor de umidade na resposta do sistema solo-sapata, a qual, segundo os autores, mostrou-se mais expressiva para os recalques que para a tensão de ruptura.

TABELA 2.4 - Influência do teor de umidade na tensão de ruptura e nos recalques

(AMAR et al., 1987)

\begin{tabular}{c|c|c|c|c}
\hline w (\%) & Sr (\%) & $\begin{array}{c}\text { Tensão de } \\
\text { ruptura }(\mathrm{kPa})\end{array}$ & $\begin{array}{c}\text { Recalque para } \\
200 \mathrm{kPa}(\mathrm{mm})\end{array}$ & $\begin{array}{c}\text { Recalque para } \\
300 \mathrm{kPa}(\mathrm{mm})\end{array}$ \\
\hline 22 & 90 & 400 & 27 & 74 \\
19 & 75 & 500 & 11 & 35 \\
\multicolumn{2}{c|}{ solo não saturado /solo saturado } & 1,25 & 0,41 & 0,47 \\
\hline
\end{tabular}

Com relação aos ensaios de longa duração, foi concluído que a influência do nível do lençol freático não foi significativa nos resultados de fluência do solo.

Ensaios em modelo para a verificação da variação do lençol freático nos recalques de uma sapata sob carregamento constante foram realizados por AGARWAL \& RANA (1987). Para tanto, foram utilizadas sapatas quadradas de 100, 150 e $200 \mathrm{~mm}$ de lado sobre um solo arenoso, as quais foram submetidas uma tensão igual à metade da tensão de ruptura obtida para o "solo seco". Através da variação do lençol freático de 0 a 1,5 B, verificou-se um aumento dos recalques com a diminuição da distância entre o nível do lençol e a base da sapata. A partir dos resultados, foi desenvolvida uma equação empírica de modo a ser obtido um fator de correção $C_{w}$ (expressão 2.9), para considerar a profundidade do lençol em relação à base da sapata $z_{w}$. Este fator de correção deve então ser multiplicado pelo valor do recalque estimado para o solo no "estado seco".

$$
\mathrm{C}_{\mathrm{w}}=1,95-0,57 \frac{\mathrm{z}_{\mathrm{w}}}{\mathrm{B}}
$$


STEESEN-BACH et al. (1987) realizaram provas de carga em placa in situ e em modelos no laboratório. Nos ensaios de laboratório, uma placa metálica quadrada de $22 \mathrm{~mm}$ de lado foi utilizada sobre uma areia contida em um recipiente circular de $200 \mathrm{~mm}$ de diâmetro e $120 \mathrm{~mm}$ de altura. A Figura 2.15 apresenta as curvas tensãorecalque em ensaios com um dos tipos de areia utilizados, para posições do lençol variando de 0 a $820 \mathrm{~mm}$ de distância da superfície. De uma maneira geral, as curvas mostram um aumento de capacidade de carga com o aumento da profundidade do lençol.

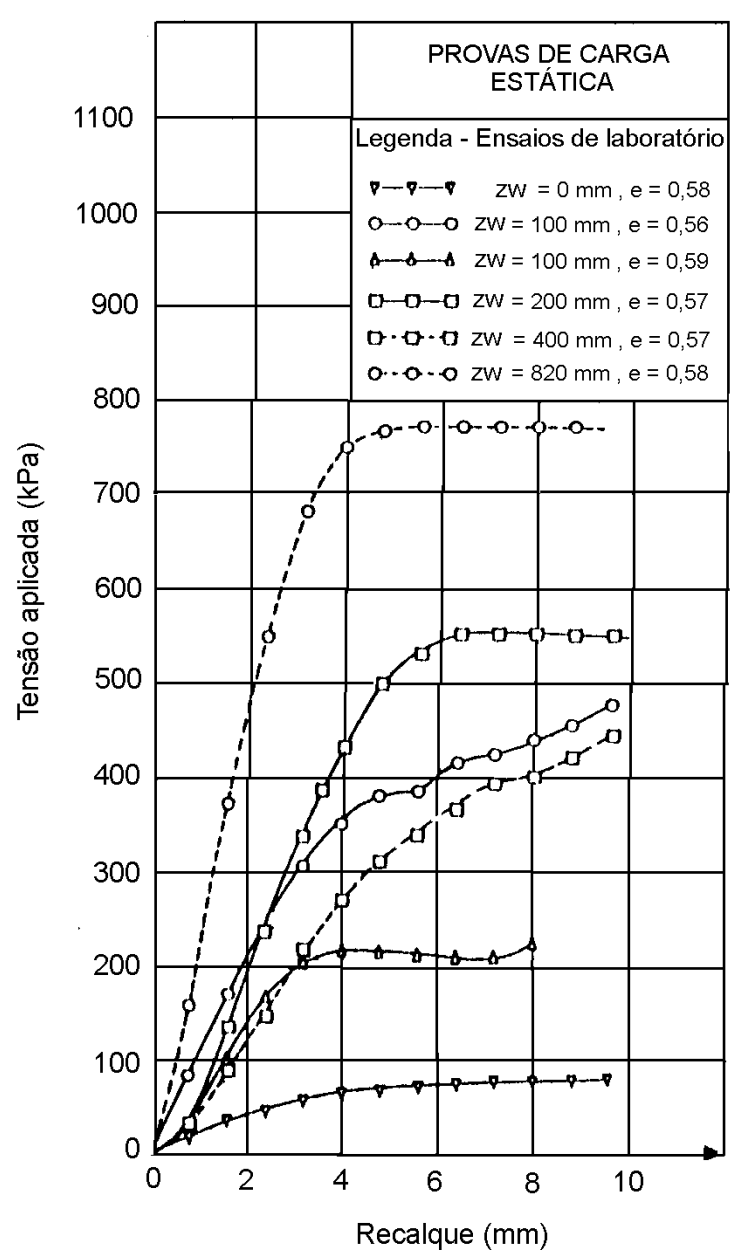

FIGURA 2.15 - Curvas tensão-recalque de ensaios em modelos (STEESEN-BACH et al., 1987)

As provas de carga em campo foram realizadas com o auxílio de placas circulares de 100 e $200 \mathrm{~mm}$ de diâmetro, instaladas a uma profundidade de 1,5 m. A sucção do solo durante os ensaios foi monitorada através de tensiômetros instalados 
até uma profundidade igual ao diâmetro da placa. $\mathrm{O}$ valor de sucção atribuído à prova de carga foi o correspondente à média dos valores lidos. Através de retroanálises por fórmulas de capacidade de carga, calculou-se o valor da coesão aparente para os ensaios de campo e de laboratório, sendo sua variação com a sucção mostrada na Figura 2.16. A coesão é representada por um parâmetro denominado "atração", definido por a = c cotg $\phi$. Observa-se um crescimento do parâmetro $a$ com o aumento da sucção.

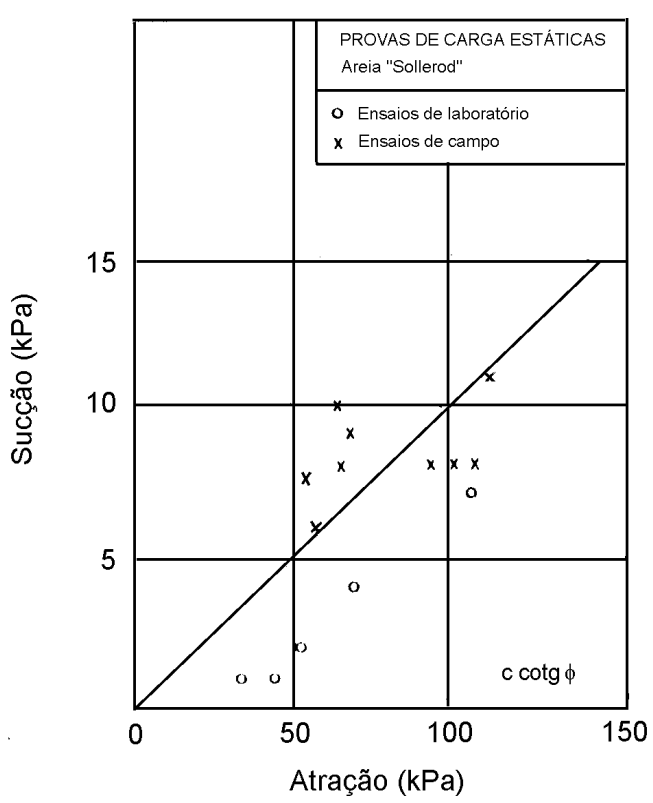

FIGURA 2.16 - Variação da "atração" com a sucção medida

(STEESEN-BACH et al., 1987)

FREDLUND \& RAHARDJO (1993) sugerem que a capacidade de carga de um solo não saturado seja obtida com o auxílio do conceito de variáveis de estado de tensão (FREDLUND \& MORGENSTERN, 1977). Dessa forma, as fórmulas "convencionais" para estimativa da capacidade de carga poderiam ser adaptadas de modo a levar em consideração a parcela referente à sucção do solo. O estado de saturação do solo é considerado na estimativa de capacidade de carga através da coesão (e não mais do peso específico, como em MEYERHOF, 1955). A coesão total é calculada através da expressão 2.10, sendo composta por uma parcela devida à coesão efetiva $c^{\prime}$ (correspondente ao estado saturado) e outra devida à sucção. 
$\mathrm{c}=\mathrm{c}^{\prime}+\left(\mathrm{u}_{\mathrm{a}}-\mathrm{u}_{\mathrm{w}}\right) \operatorname{tg} \phi^{\mathrm{b}}$

onde:

$\left(\mathrm{u}_{\mathrm{a}}-\mathrm{u}_{\mathrm{w}}\right)$ - sucção matricial;

$\phi^{\mathrm{b}}$ - ângulo indicativo da taxa do aumento da resistência ao cisalhamento relacionada à sucção matricial.

A Figura 2.17, extraída de FREDLUND \& RAHARDJO (1993), ilustra a influência da sucção matricial na capacidade de carga do solo sob um elemento de fundação superficial. A análise foi feita para sapatas corridas com largura de 0,5 e 1 $\mathrm{m}$, assentes a uma profundidade de $0,5 \mathrm{~m}$. Os resultados mostram uma forte influência da sucção matricial na capacidade de carga.

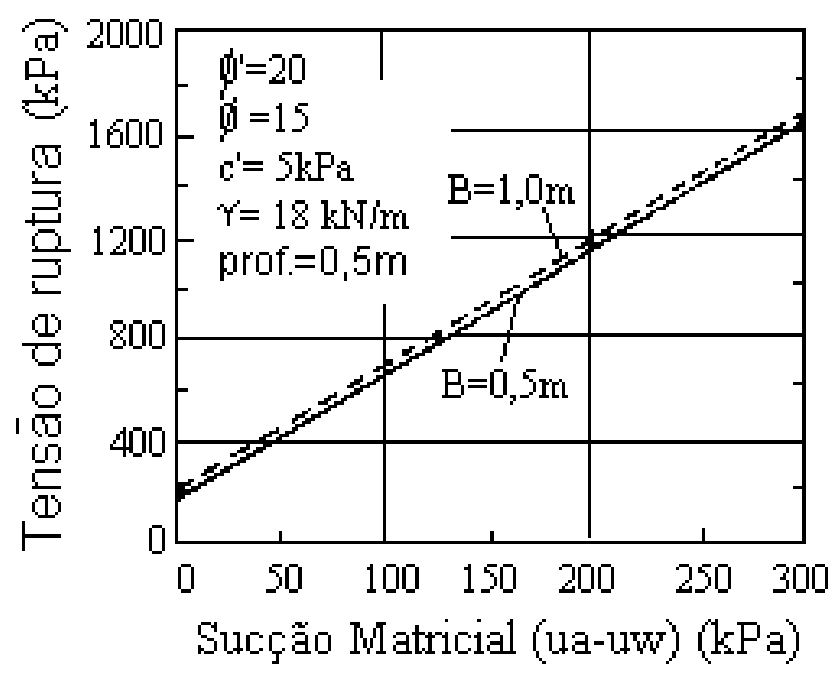

FIGURA 2.17- Tensão de ruptura de sapatas corridas para vários valores de sucção matricial (FREDLUND \& RAHARDJO, 1993) 


\section{2 - TDR: UMA NOVA ALTERNATIVA PARA A DETERMINAÇÃO DO TEOR DE UMIDADE DO SOLO}

A umidade do solo é um parâmetro essencial em muitas análises geotécnicas, sendo sua quantificação de suma importância, pois este parâmetro guarda uma relação direta com a sucção do solo. A obtenção do teor de umidade através de pesagem e secagem de amostras em estufa, ou seja, de forma gravimétrica é ainda considerada a técnica padrão. Contudo, esta técnica torna-se insatisfatória em situações nas quais se necessita de rapidez na obtenção dos resultados e quando há um grande volume de dados, como por exemplo, o monitoramento contínuo de um maciço, em profundidades e locais diversos. Outra desvantagem da técnica gravimétrica reside em sua natureza destrutiva.

Assim, tais limitações levaram ao desenvolvimento de outros métodos mais evoluídos. Técnicas nucleares, por exemplo, são consideradas não destrutivas e permitem o monitoramento da umidade com relativo dinamismo. Contudo, também apresentam seus inconvenientes. No caso de utilização de sonda de nêutrons pode-se citar a impossibilidade da obtenção de medidas próximas à superfície do solo, o perigo iminente de contaminação por radiação e a necessidade de laboriosas calibrações em campo.

A técnica da Reflectometria no Domínio do Tempo (do inglês, Time Domain Reflectometry - TDR) tem se mostrado promissora, eliminando algumas das limitações atribuídas a outros métodos na obtenção do teor de umidade. Empregada inicialmente pelas companhias telefônicas e de energia elétrica para testar possíveis falhas em suas linhas de transmissão, não tardou para lhe serem atribuídas outras aplicações. Além da obtenção do teor de umidade do solo, a técnica de TDR também tem sido empregada no monitoramento de deformações em maciços rochosos e medidas do nível do lençol freático (HUANG \& DOWDING, 1998). 


\subsection{1 - A constante dielétrica}

Na técnica de TDR, o teor de umidade do solo é obtido por meio de medição da constante dielétrica do solo. Uma definição de constante dielétrica pode ser concebida utilizando como exemplo um capacitor de placas paralelas. A capacitância de um capacitor de placas paralelas é dada por:

$$
\mathrm{C}_{0}=\varepsilon_{0} \frac{\mathrm{A}}{\mathrm{d}}
$$

onde:

$\mathrm{C}_{0}$ - capacitância;

$\varepsilon_{0}$ - permissividade elétrica do vácuo $=8,85 \times 10^{-12} \mathrm{~N} \mathrm{~m}^{2} / \mathrm{C}^{2}$;

A - área da superfície da placa do capacitor;

d - distância de separação das placas.

No entanto, quando se preenche o espaço entre as placas com um material dielétrico, a capacitância é alterada por um fator numérico $\varepsilon$, chamado constante dielétrica, tornando-se:

$$
\mathrm{C}=\mathrm{C}_{0} \frac{\varepsilon_{\mathrm{m}}}{\varepsilon_{0}}=\mathrm{C}_{0} \varepsilon
$$

onde:

C - capacitância após a introdução do material dielétrico;

$\varepsilon_{\mathrm{m}}$ - permissividade elétrica do material;

$\varepsilon$ - permissividade relativa ou constante dielétrica.

A expressão 2.12 é válida não somente para capacitores de placa paralelas, mas para todos os tipos. A constante dielétrica do vácuo é, por definição, igual à unidade. No ar, $\varepsilon$ é um pouco maior que 1 , mas a diferença é tão pequena que a mesma pode ser considerada unitária. Para a água, a constante dielétrica vale 80,4 à temperatura de $20^{\circ} \mathrm{C}$. 


\subsection{2 - O princípio da técnica de TDR}

Com o mesmo princípio de funcionamento do radar, a técnica de reflectometria no domínio do tempo consiste na medição de $\varepsilon$ através do tempo gasto por um pulso eletromagnético para percorrer uma linha de transmissão e retornar à fonte.

Um aparelho denominado testador de cabos (disponível comercialmente) gera os pulsos sob determinada freqüência. A linha de transmissão é constituída por uma sonda cravada no solo e por um cabo que a liga ao testador de cabos. Por viajar em um meio constituído por diferentes materiais, parte do sinal gerado pelo aparelho será refletida cada vez que encontrar um novo material, enquanto outra parte continuará o trajeto através da linha. Essas reflexões devem-se às diferentes impedâncias dos materiais que formam a linha de transmissão, ou que estão em contato com a mesma. Assim, torna-se possível uma identificação clara das diversas partes constituintes da linha de transmissão. Um osciloscópio propicia a visualização do sinal através de um gráfico, cujo eixo das abscissas representa o tempo de percurso e o eixo das ordenadas, a voltagem do sinal. Técnicas usadas para a análise do sinal podem ser obtidas em TOPP et al. (1982a) e PETERSEN et al. (1995). A Figura 2.18 apresenta um esquema do equipamento e de um sinal típico, onde os números situados ao longo da linha representam as posições equivalentes no sinal recebido.

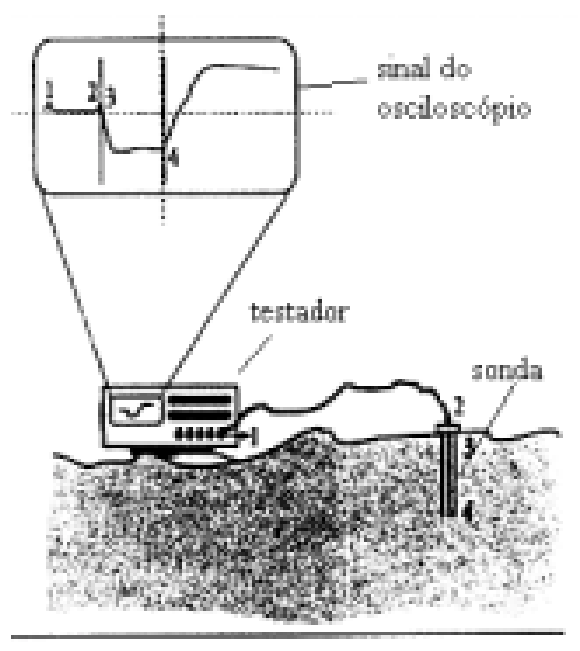

FIGURA 2.18 - Esquema de um equipamento utilizado na técnica de TDR (CONCIANI et al., 1995) 
A velocidade de propagação do pulso $v$, considerando o caminho de ida e volta, é dada por:

$\mathrm{v}=\frac{2 \mathrm{~L}}{\mathrm{t}}$

onde:

L - comprimento da linha de transmissão;

$\mathrm{t}$ - tempo gasto pelo sinal para viajar na linha e retornar à fonte.

A teoria do eletromagnetismo mostra que a velocidade também pode ser expressa em termos da constante dielétrica do meio através da expressão 2.14 (KRAUS, 1984):

$\mathrm{v}=\frac{\mathrm{c}}{\sqrt{\varepsilon}}$

onde c é a velocidade da luz no vácuo $\left(3 \times 10^{8} \mathrm{~m} / \mathrm{s}\right)$.

Combinando 2.13 e 2.14 , tem-se:

$\varepsilon=\left(\frac{\mathrm{ct}}{2 \mathrm{~L}}\right)^{2}$

A expressão 2.15 mostra como a constante dielétrica pode ser medida sabendo-se o tempo de percusso do sinal e o comprimento da sonda, o qual será influenciado pelo tipo de material em contato com o condutor. Não obstante, em vez de fornecerem o tempo de percurso do sinal, alguns modelos mais modernos de testadores de cabos fornecem o comprimento da linha de transmissão, denominado “comprimento virtual”. Neste caso, é utilizada a expressão 2.16 para o cálculo de $\varepsilon$ :

$\varepsilon=\left(\frac{\mathrm{S}_{\mathrm{TDR}}}{\mathrm{v}_{\mathrm{p}} \mathrm{L}}\right)^{2}$

onde: 
$\mathrm{S}_{\mathrm{TDR}}$ - comprimento da linha de transmissão lido no aparelho;

$\mathrm{v}_{\mathrm{p}}$ - velocidade de propagação do sinal numa linha de transmissão dada como uma percentagem da velocidade da luz no vácuo.

O teor de umidade do solo é obtido através de correlações empíricas com a constante dielétrica. TOPP et al. (1980) foram os primeiros a propor uma equação empírica relacionando $\varepsilon$ com o teor de umidade volumétrica $\theta$ obtido a partir de cinco tipos de solo, desde uma argila até um solo arenoso, passando por materiais artificiais (expressão 2.17).

$\theta=-5,3 \cdot 10^{-2}+2,92 \cdot 10^{-2} \varepsilon-5,5 \cdot 10^{-4} \varepsilon^{2}+4,3 \cdot 10^{-6} \varepsilon^{3}$

\subsection{3 - A influência de outros parâmetros na constante dielétrica do solo}

Através de seus experimentos, TOPP et al. (1980) concluíram que $\varepsilon$ é fortemente dependente do teor de umidade e praticamente independente da textura do solo, do peso específico, da temperatura e do teor de sal. Talvez por causa dessa conclusão e/ou para poupar calibrações em laboratório, a equação 2.17 passou a ser largamente utilizada por outros pesquisadores na determinação do teor de umidade de diversos tipos de solo. Contudo, resultados divergentes da equação de TOPP et al. (1980) têm sido encontrados na literatura, devido à influência de outros parâmetros do solo além do teor de umidade sobre a constante dielétrica, como será visto a seguir.

DASBERG \& HOPMANS (1992) comparam curvas de $\theta$ versus $\varepsilon$ de um solo arenoso (Hanford sandy loam) e de um argiloso (Yolo clay), como mostra a Figura 2.19. A título de comparação, é plotada na mesma figura a equação de TOPP et al. (1980). Resultados em concordância com a equação 2.17 foram obtidos apenas para o solo arenoso. Para um mesmo teor de umidade, o solo argiloso apresenta um valor de $\varepsilon$ inferior ao do solo arenoso. Os autores atribuem este fato às moléculas de água que aderem à superfície sólida da partícula de argila (água adsorvida), as quais possuem uma constante dielétrica baixa, próxima da do gelo $(\varepsilon=3)$. Uma vez que os 
solos com textura mais fina possuem uma maior área específica e uma maior quantidade de água adsorvida, sua constante dielétrica será inferior à de solos com textura mais grossa.

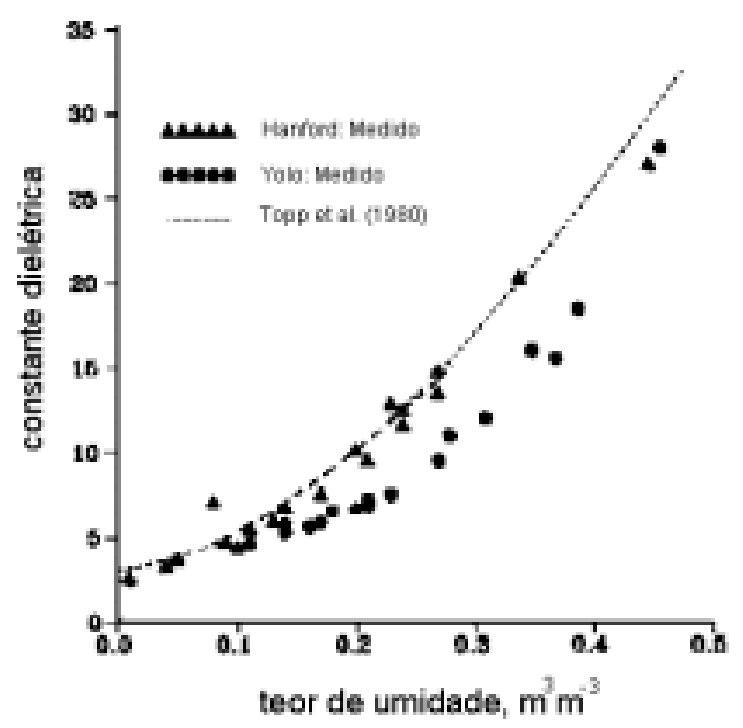

FIGURA 2.19 - Relação entre constante dielétrica e umidade volumétrica para um solo argiloso e um solo arenoso (DASBERG \& HOPMANS, 1992)

Em solo com alto percentual de matéria orgânica (em torno de $12 \%$ ), HERKELRATH et al. (1991) encontraram valores de $\varepsilon$ até $30 \%$ inferiores aos fornecidos pela equação 2.17. A Figura 2.20 compara os resultados.

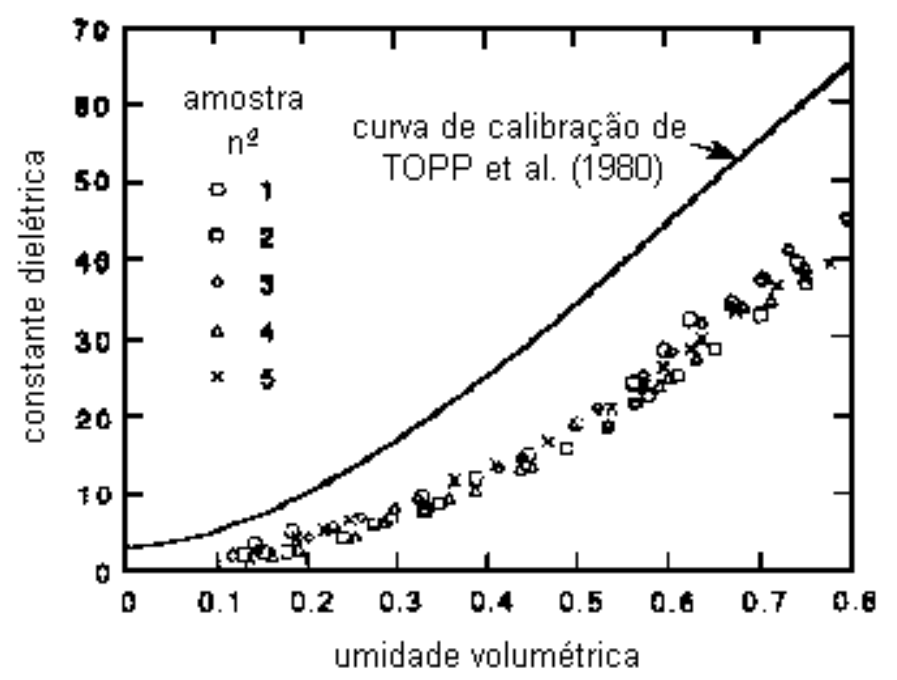

FIGURA 2.20 - Relação entre teor de umidade volumétrica e constante dielétrica para cinco tipos de solo (HERKELRATH et al., 1991) 
JACOBSEN \& SCHJONNING (1993) obtiveram uma curva de calibração a partir da utilização de cinco tipos de solo distintos (expressão 2.18). Na equação proposta são incluídos os parâmetros peso específico seco do solo, percentagem de argila e percentagem de matéria orgânica. Foi observada uma concordância com a equação de TOPP et al. (1980) apenas na faixa que $\theta$ é inferior a $18 \%$. Através de comparações de resultados de $\theta$ obtidos através da equação 2.18 e por pesagem de amostras, os autores observaram que a inclusão dos outros parâmetros nessa equação causaram uma melhora nos resultados, sendo $\gamma_{d}$ o mais influente. Foi observado que solos mais compactos possuem maior constante dielétrica que solos menos compactos, para um mesmo teor de umidade, pois o efeito da compacidade em $\varepsilon$ origina-se de uma contribuição da fase sólida.

$$
\begin{aligned}
& \theta=-3,41 \cdot 10^{-2}+3,45 \cdot 10^{-2} \varepsilon-11,4 \cdot 10^{-4} \varepsilon^{2}+17,1 \cdot 10^{-6} \varepsilon^{3}-3,70 \cdot 10^{-2} \gamma_{\mathrm{d}} \\
& +7,36 \cdot 10^{-4}(\% \text { arg ila })+47,7 \cdot 10^{-4}(\% \text { mat.org. })
\end{aligned}
$$

\subsection{4 - Modelos de sonda}

Uma vez utilizada a técnica, o sucesso de seu funcionamento dependerá primordialmente da sonda empregada. Os primeiros experimentos para a medição de $\varepsilon$ do solo foram conduzidos em laboratório utilizando uma sonda coaxial, ou seja, composta por um cilindro externo, no qual o solo era introduzido, e uma haste interna (TOPP et al., 1980). As dimensões eram de $50 \mathrm{~mm}$ de diâmetro interno e comprimentos de 0,33 m e $1 \mathrm{~m}$, sendo um esquema mostrado na Figura 2.21. Cápsulas porosas espaçadas de $50 \mathrm{~mm}$ ao longo do comprimento da sonda permitiam a inserção ou remoção de água do solo.

Em experimentos posteriores, passou-se a utilizar sondas constituídas por um par de hastes paralelas. Esta nova configuração possui a vantagem de permitir medidas em campo, uma vez que causa pouca perturbação ao solo no momento da instalação. TOPP et al. (1982a, b) empregaram em ensaios laboratoriais sondas paralelas compostas por hastes de latão com $12,7 \mathrm{~mm}$ de diâmetro, espaçamento de $50 \mathrm{~mm}$ e comprimento de $1,10 \mathrm{~m}$. O solo foi compactado ao redor de seis sondas 
posicionadas na vertical, dentro de um tanque cilíndrico de polietileno com altura de $1,10 \mathrm{~m}$ e $560 \mathrm{~mm}$ de diâmetro.

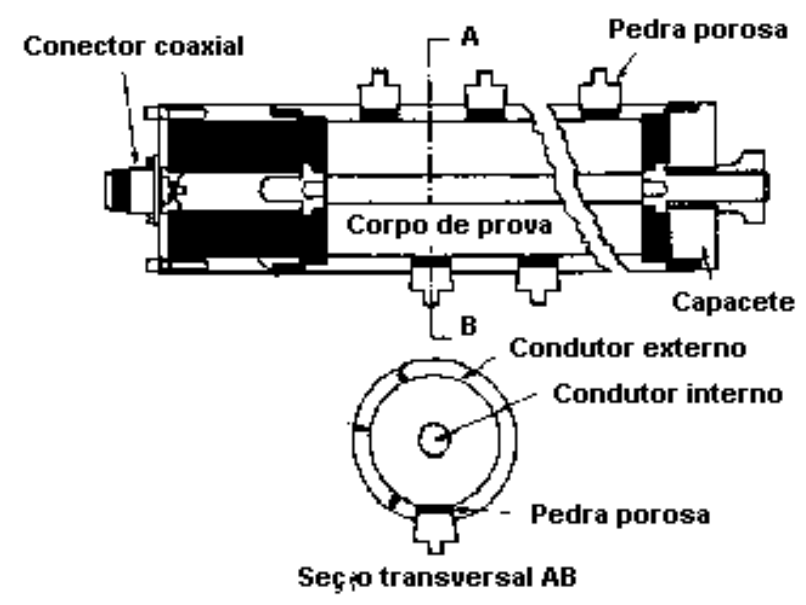

FIGURA 2.21 - Esquema de sonda coaxial empregada por TOPP et al. (1980)

Diminuindo o diâmetro das hastes em localidades específicas, obtêm-se descontinuidades no sinal recebido pelo testador de cabos, o que torna possível a realização de leituras de $\varepsilon$ em diversas profundidades ao longo de um perfil. Dessa forma, como mostra a Figura 2.22, além de modelos contínuos foram também utilizadas sondas descontínuas (ou segmentadas) que permitiam medições às profundidades de 0,$1 ; 0,3 ; 0,6$ e $0,9 \mathrm{~m}$. Os autores concluem que, em sondas segmentadas, descontinuidades além de 0,6 m causam uma reflexão do sinal pequena para uma interpretação de confiança. Não obstante, afirmam que as sodas segmentadas constituem um modo conveniente para se determinar perfis de umidade.

TOPP \& DAVIS (1985) utilizaram em campo os mesmos modelos de sondas segmentadas e contínuas empregadas por TOPP et al. (1982a, b), instalados vertical e horizontalmente no maciço. Os modelos instalados na posição vertical eram do tipo contínuo e descontínuo, com comprimentos de 0,25 a 1,0 m. As sondas dispostas horizontalmente eram apenas do tipo contínuo com comprimento de $0,4 \mathrm{~m}$, sendo instaladas na parede de uma vala posteriormente reaterrada. Os autores afirmam que, apesar de uma única sonda descontínua fornecer informações equivalentes a cinco 
sondas tradicionais, houve dificuldades de uso in situ, pois o sinal referente às profundidades de 0,5 e 0,75 m não era sempre detectável. Por isso, esses modelos necessitariam de um melhor aprimoramento para uso no campo.

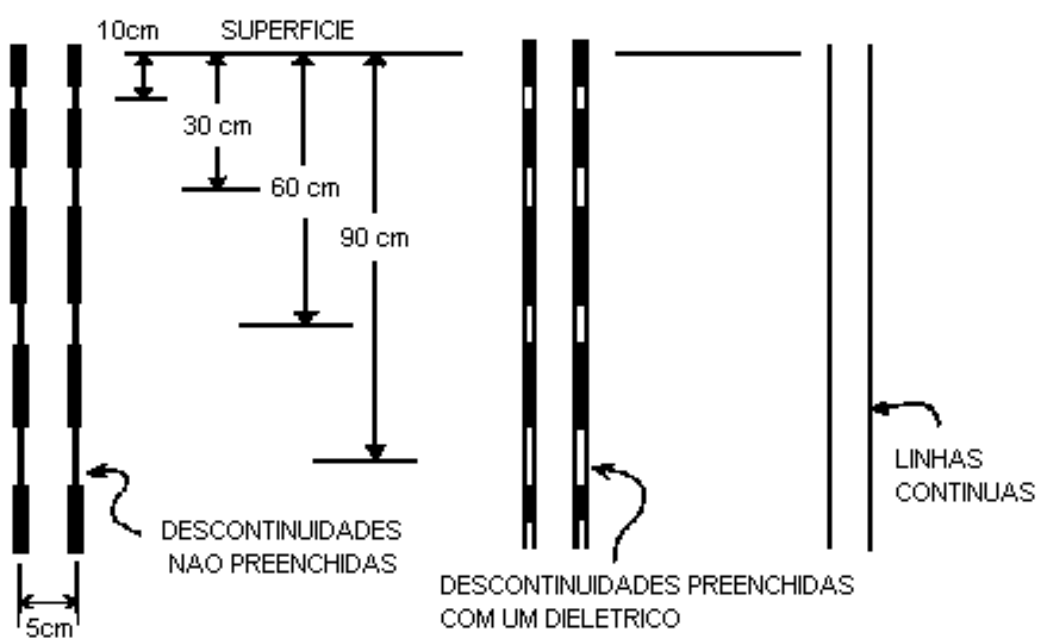

FIGURA 2.22 - Esquemas de sondas segmentada e contínua empregadas por TOPP et al. (1982a, b)

Como a geometria da sonda paralela difere da geometria do cabo coaxial que a conecta ao testador de cabos, há uma perda considerável de sinal na interface. De modo a reduzir essas perdas, um aparelho denominado "casador de impedância" é geralmente conectado entre o cabo e a sonda. Entretanto, esse equipamento pode ser uma fonte de ruído indesejável, dificultando a análise do sinal. Dessa forma, foi observado por ZEGELIN et al. (1989) que hastes múltiplas dispostas radialmente confinam melhor o sinal e diminuem as perdas, pois sua geometria simula a de uma linha coaxial, dispensando o casador de impedância (Figura 2.23). 


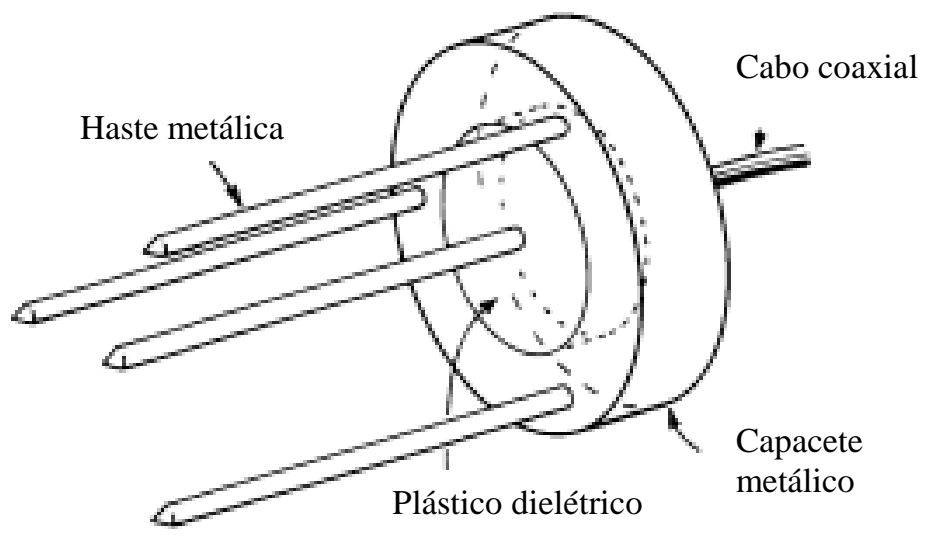

FIGURA 2.23 - Esquema de sonda coaxial multi-hastes (ZEGELIN et al., 1989)

Foram testadas sondas metálicas de três e quatro hastes de dimensões $L=150$ $\mathrm{mm}, D=4,7 \mathrm{~mm}$ e espaçamento $e$ variando entre 15 e $100 \mathrm{~mm}$. Dentre as configurações adotadas, verificou-se um melhor desempenho com a sonda de quatro hastes. Na Figura 2.24 é realizada uma comparação da distribuição do campo elétrico em torno das sondas de três e quatro hastes comparativamente à tradicional, de duas hastes. Os autores concluem que as sondas multi-hastes apresentam uma melhor distribuição do campo elétrico que as de duas hastes, além de serem mais precisas e causarem um menor nível de ruído.

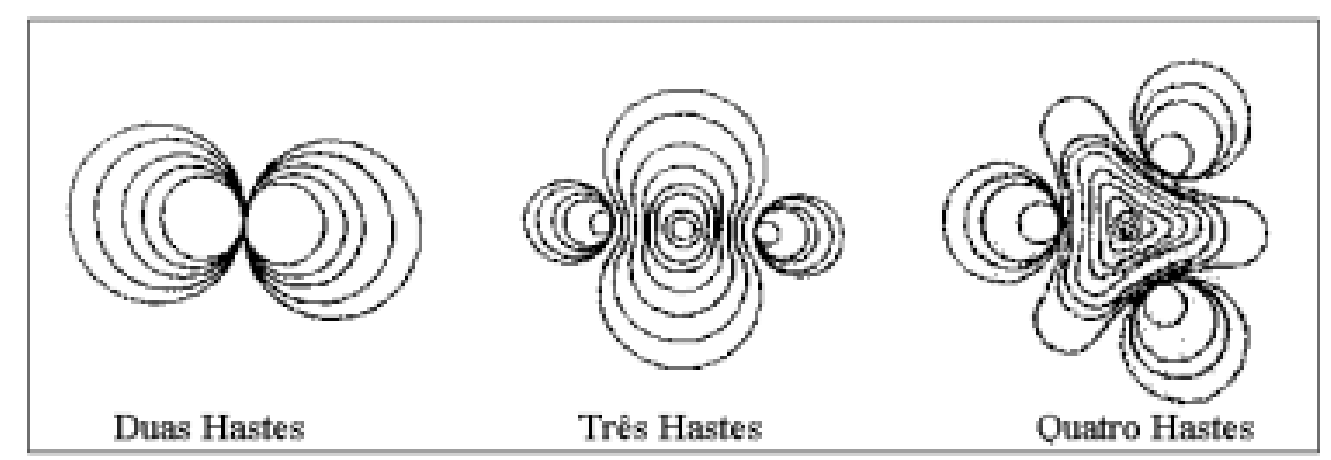

FIGURA 2.24 - Regiões abrangidas pelo campo elétrico das sondas (ZEGELIN et al., 1989) 
Foram também desenvolvidos alguns modelos de sonda que podem ser classificados como "especiais", pois fornecem medidas de outros parâmetros do solo, além da constante dielétrica. Por exemplo, BAKER \& GOODRICH (1987) produziram um tipo de sonda paralela que também funciona como um aparelho que mede a condutividade térmica do solo. A sonda consiste de duas hastes de aço inoxidável, um das quais possui um resistor em seu interior e um thermocouple, como mostra a Figura 2.25.

BALMGARTNER et al. (1994) desenvolveram uma sonda paralela que permite, além de medidas do teor de umidade do solo, medidas de sucção matricial e de concentração de solutos. Com $131 \mathrm{~mm}$ de comprimento, a haste da sonda é oca e possui em sua extremidade inferior uma parte permeável de $25 \mathrm{~mm}$ de comprimento, assemelhando-se a um tensiômetro. A sucção matricial é medida através de um transdutor de pressão, acoplado à extremidade superior da haste.

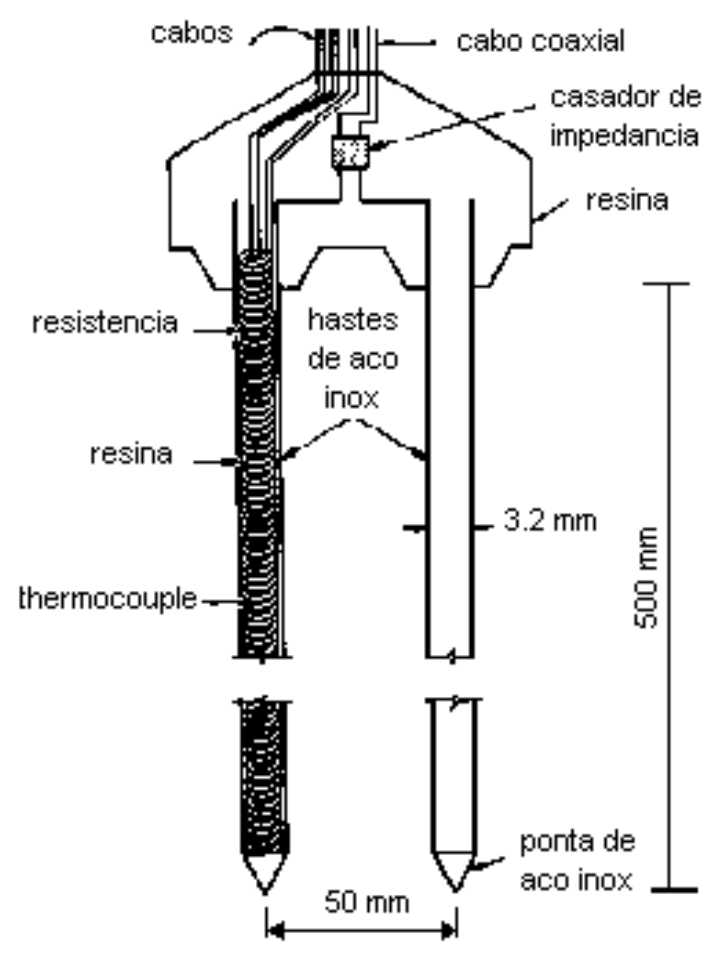

FIGURA 2.25 - Esquema da sonda concebida por BAKER \& GOODRICH (1987) 
O diâmetro e o espaçamento das hastes de uma sonda constituem os parâmetros que determinam o volume de solo que contribui efetivamente para a medida da constante dielétrica. Segundo PETERSEN et al. (1995), o espaçamento é a variável de maior influência. KNIGHT (1992) recomenda que o diâmetro da haste seja o maior possível em relação ao espaçamento, de modo a minimizar a concentração de energia em torno desta (skin effect). Isto representa um dilema, uma vez que quanto maior o diâmetro da haste, mais perturbação ao solo será causada no momento da cravação. KNIGHT (1992) sugere uma razão espaçamento sobre diâmetro não superior a 10. Entretanto, ZEGELIN et al. (1989) testaram modelos de sonda com $e / D$ variando de 3 a 21 , concluindo não ter havido alteração na constante dielétrica nesta faixa.

\subsection{5 -O emprego da técnica em campo}

Uma das primeiras medidas de $\theta$ em campo através da técnica de TDR foi realizada por TOPP et al. (1984). Medidas da constante dielétrica do solo foram obtidas em profundidades entre 50 e $300 \mathrm{~mm}$, através de sondas paralelas instaladas horizontal e verticalmente no solo. Foram realizadas diversas séries de medidas de $\varepsilon$ com o TDR, sendo a determinação de $\theta$ a partir de $\varepsilon$ obtida através da equação de TOPP et al. (1980). Para testar a repetibilidade da técnica, os resultados foram confrontados com medidas de umidade gravimétrica de amostras retiradas no mesmo local de instalação da sonda. No caso das sondas instaladas horizontalmente, a média da diferença entre o teor de umidade volumétrica obtido com o TDR $\left(\theta_{t}\right)$ e o teor de umidade volumétrica obtido por pesagem de amostras $\left(\theta_{\mathrm{g}}\right)$ foi de $1,3 \%$, com um desvio padrão de $0,6 \%$. Para as sondas verticais, entre as diversas séries de medidas realizadas, verificou-se uma diferença média máxima entre $\theta_{\mathrm{t}}$ e $\theta_{\mathrm{g}}$ de $3,7 \%$, com desvio padrão de 2,9 \%. A Figura 2.26 compara os valores de $\theta$ obtidos através de ambas as técnicas, para o caso de sondas instaladas verticalmente. 


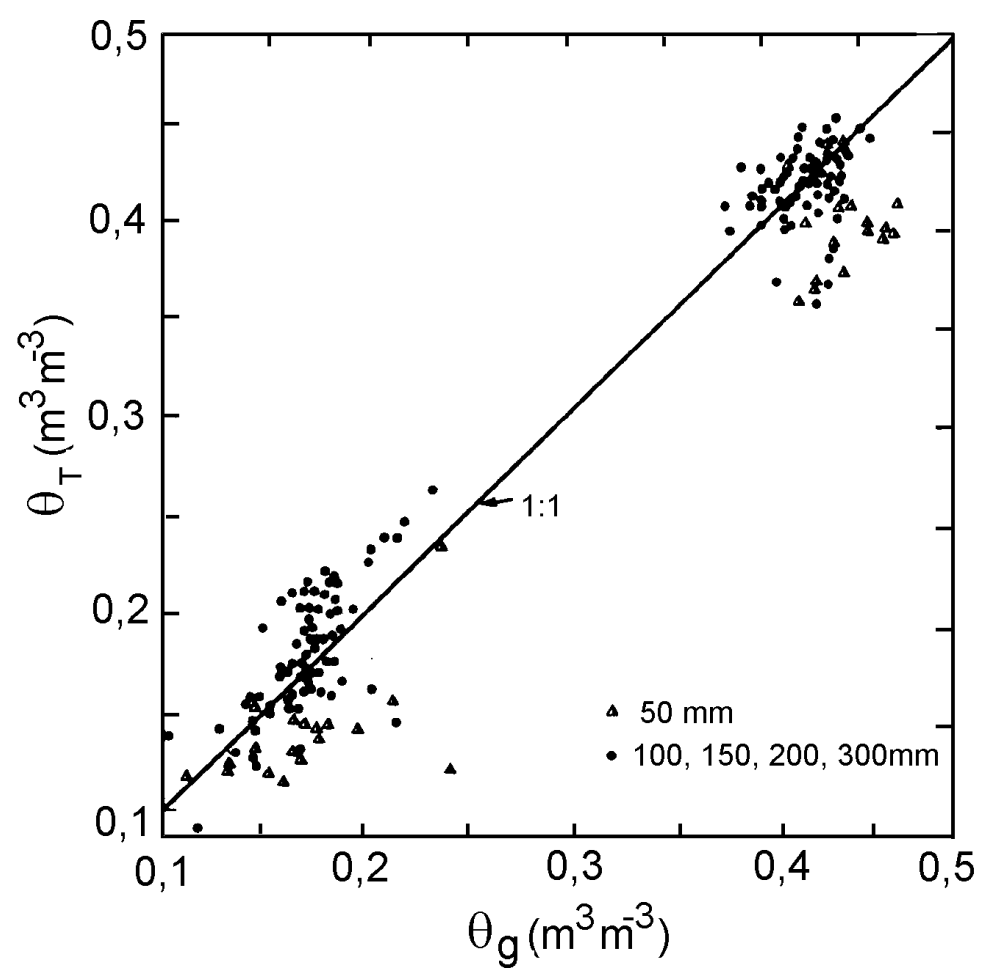

FIGURA $2.26-\theta_{\mathrm{g}}$ versus $\theta_{\mathrm{t}}$ para sondas de 50 a $300 \mathrm{~mm}$ (TOPP et al., 1984)

TOPP \& DAVIS (1985) apresentam perfis de variação do teor de umidade com a profundidade em um solo argiloso, obtidos através de sondas contínuas e segmentadas, instaladas vertical e horizontalmente. Para as sondas contínuas, foi observada uma diferença média máxima entre $\theta_{\mathrm{t}} \mathrm{e} \theta_{\mathrm{g}}$ em torno de $2,1 \%$, com um desvio padrão de $6,1 \%$. Já para as descontínuas, obteve-se $\left(\theta_{\mathrm{t}}-\theta_{\mathrm{g}}\right)$ médio de $4,1 \%$, com um desvio padrão de 5,3 \%. A Figura 2.27 mostra a variação do teor de umidade do solo com a profundidade, para sondas contínuas instaladas horizontal e verticalmente. De modo a possibilitar comparações, é também plotada a variação do teor de umidade obtida através da técnica de pesagem de amostras. 


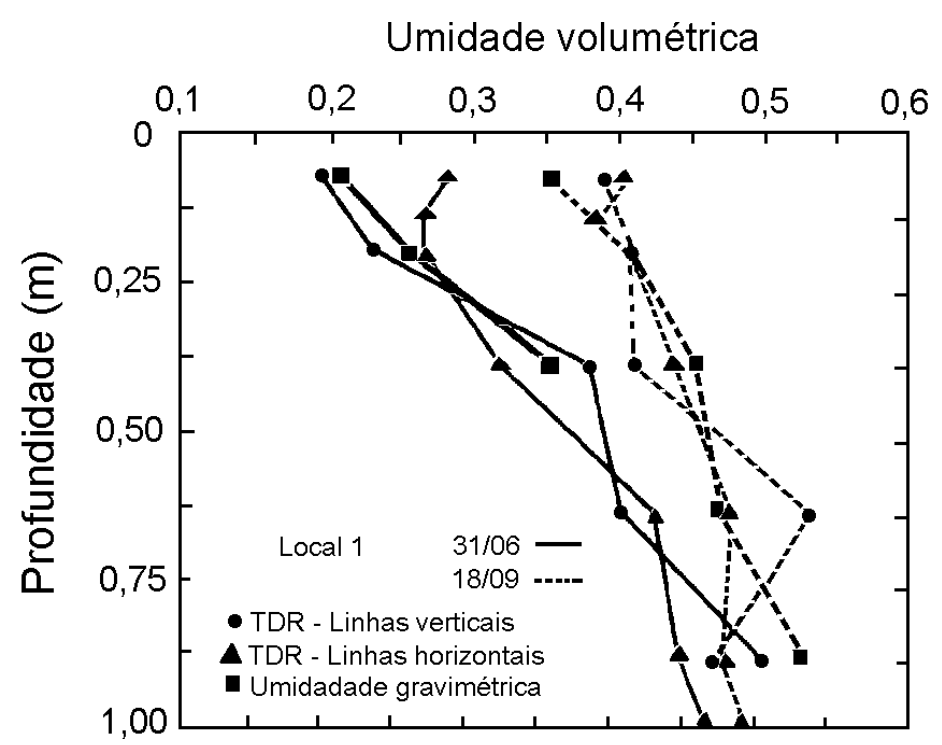

FIGURA 2.27 - Perfis de teor de umidade comparando dados de sondas verticais e horizontais com dados obtidos a partir de coleta de amostras (TOPP \& DAVIS, 1985)

Segundo TOPP \& DAVIS (1985), as diferenças dos valores de umidade obtidos através das duas técnicas são atribuídas à variabilidade do solo e às imprecisões inerentes às técnicas.

Comparações entre resultados de teor de umidade volumétrica obtidos através da técnica de TDR e com a utilização de sonda de nêutrons em campo são apresentadas em BAKER \& ALLMARAS (1990) e KUJALA \& RAVASKA (1994). As Figuras 2.28a e b, extraídas de BAKER \& ALLMARAS (1990), apresentam um perfil de teor de umidade medido através de ambas as técnicas quando o solo se encontrava congelado. Nesse caso, $\theta$ medido através da técnica de TDR será equivalente à quantidade de água no solo no estado líquido, uma vez que a constante dielétrica do gelo é aproximadamente igual a do solo "seco". Por outro lado, medidas com sonda de nêutrons não fazem distinção quanto ao estado apresentado pela água, fornecendo assim o teor de umidade total do solo. Dessa forma, a diferença entre as medidas das duas técnicas irá representar a quantidade de água no estado sólido no solo. A Figura $2.28 \mathrm{c}$ apresenta medidas de $\theta$ com ambas as técnicas no momento que todo o gelo no maciço havia derretido. Destaca-se a boa convergência entre os resultados observados nesse último caso. 

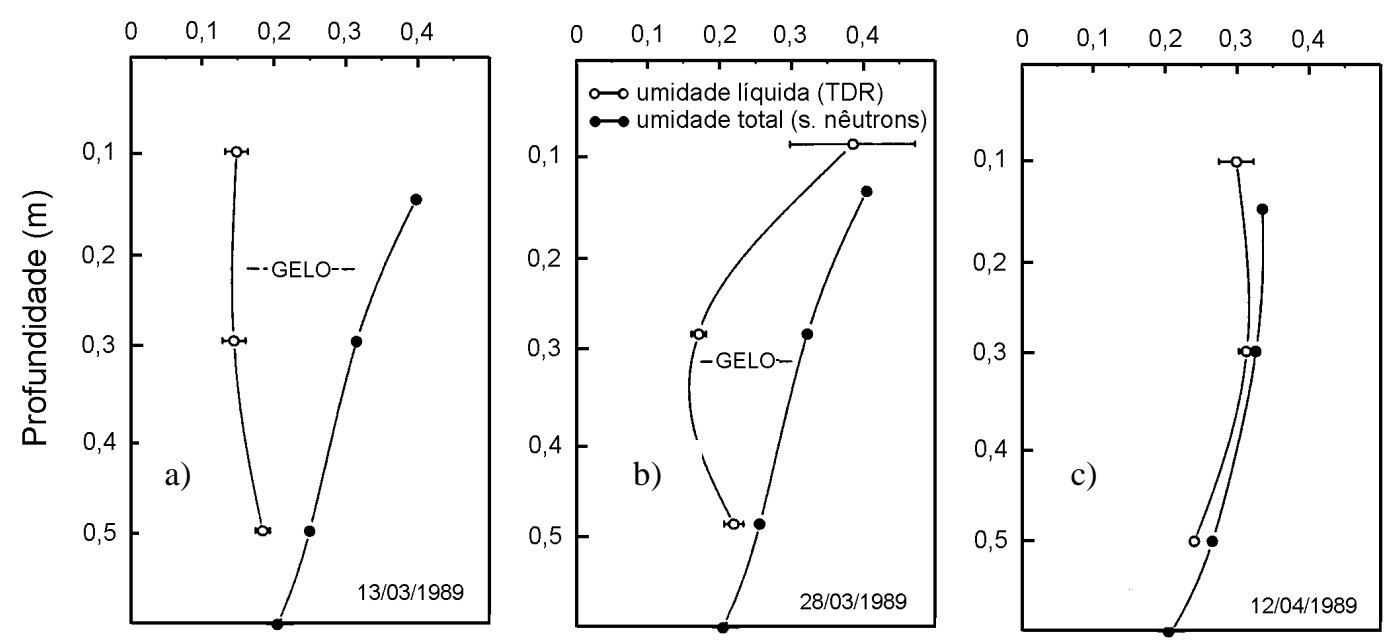

Umidade volumétrica

FIGURA 2.28 - Perfis de teor de umidade obtidos através das técnicas de TDR e de sonda de nêutrons

(BAKER \& ALLMARAS, 1990)

\subsection{6 - Utilização da técnica para obtenção da sucção}

A obtenção da sucção matricial do solo constitui uma aplicação relativamente nova da técnica. Uma das primeiras referências apontando o uso da técnica para esta finalidade remonta a PHENE II et al. (1988). Sucintamente, esses autores descrevem a utilização de um "sensor" de TDR que utiliza uma "matriz de referência" de cerâmica, através da qual eram medidos os valores de $\varepsilon$. Calibrações realizadas com o auxílio de uma câmara de Richards permitiam obter valores de $\left(\mathrm{u}_{\mathrm{a}}-\mathrm{u}_{\mathrm{w}}\right)$, a partir de $\varepsilon$.

Seguindo uma abordagem diferente, BAUMGARTNER et al. (1994) desenvolveram uma sonda especial para medidas de sucção matricial do solo em campo, como descrito no item 2.4.4, que possibilitava a medição de $\left(u_{a}-u_{w}\right)$ diretamente da sonda, acoplando-a a um tensiômetro. A Figura 2.29 apresenta os resultados obtidos, comparando o potencial matricial com a profundidade do lençol freático. 


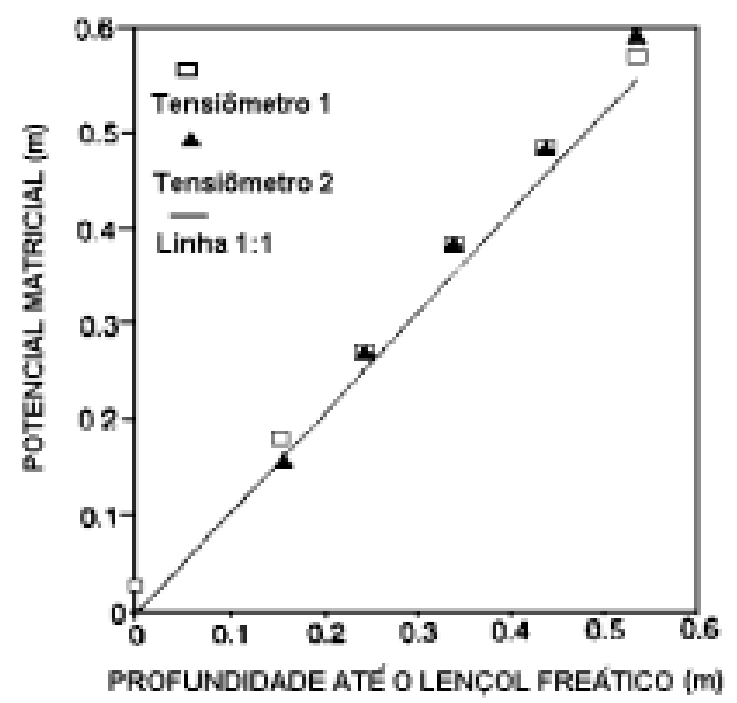

FIGURA 2.29 - Relação entre o potencial matricial e a profundidade do lençol freático

(BAUMGARTNER et al., 1994)

Uma maneira mais simplificada de se medir a sucção do solo consiste na utilização de uma curva de calibração $\theta-\varepsilon$ e, em seguida, através da curva característica desse solo, chegar a valores de $\left(\mathrm{u}_{\mathrm{a}}-\mathrm{u}_{\mathrm{w}}\right)$, como realizaram CONCIANI et al. (1996). Obtém-se assim, uma terceira curva correlacionando a constante dielétrica com a sucção matricial do solo, como mostra a Figura 2.30. Segundo os autores, uma boa concordância foi observada com resultados de tensiômetros.

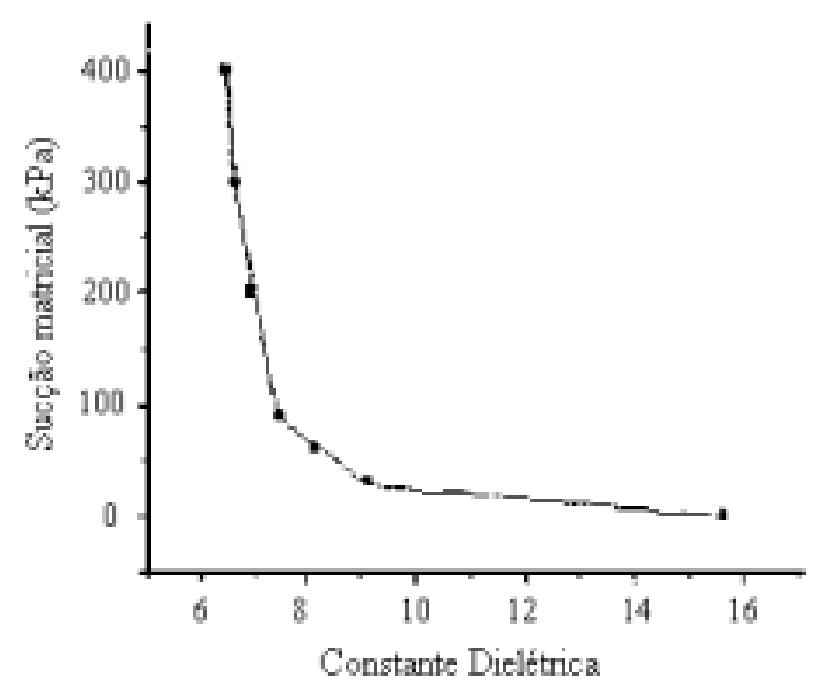

FIGURA 2.30 - Curva de sucção matricial como uma função da constante dielétrica (CONCIANI et al., 1996) 
Voltando à abordagem proposta por PHENE II et al. (1988), COOK \& FREDLUND (1998) utilizaram configurações de sondas de três e quatro hastes (seguindo o modelo de ZEGELIN et al., 1989) inseridas numa cápsula porosa, constituindo o que os autores denominaram "sensor de sucção matricial". Diversos materiais para fixar a sonda na cápsula foram testados. A correlação entre $\varepsilon$ e $\left(u_{a}\right.$ $\mathrm{u}_{\mathrm{w}}$ ) foi obtida com o auxílio de uma câmara de Richards, na qual o conjunto sonda + cápsula era inserido. A Figura 2.31 apresenta curvas de calibração para diversos sensores, comparando-as com a curva de calibração teórica, calculada utilizando a curva característica do material cerâmico. Observa-se que há uma diferença significativa entre os valores teóricos e os observados, sendo $\varepsilon$ no caso de total saturação muito menor que o valor teórico. Os autores atribuem esse problema ao excesso de concentração de energia na superfície das hastes, por possuírem um diâmetro reduzido (skin effect) e ao problema de bolhas de ar aprisionadas entre a sonda e a cápsula. É concluído que maiores pesquisas devem ser realizadas em busca de um material cerâmico mais apropriado.

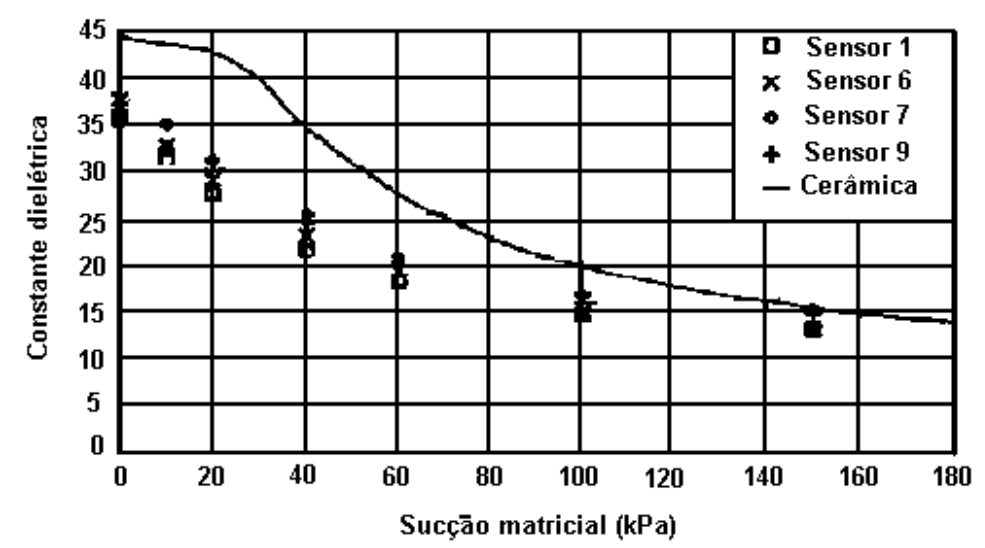

FIGURA 2.31 - Curvas de calibração típicas para diversos sensores de sucção matricial, juntamente com a curva de calibração teórica (COOK \& FREDLUND, 1998) 


\section{CAPÍTULO 3 - LOCAL DA PESQUISA}

\section{1 - GEOLOGIA LOCAL}

A cidade de São Carlos - SP está localizada na zona de transição das unidades geomorfológicas das Cuestas Basálticas e do Planalto Ocidental. Situada a cerca de 800 m de altitude em relação ao nível do mar, assenta-se sobre as rochas do Grupo São Bento, compostas por arenitos da Formação Botucatu e Pirambóia e derrames de efusivas basálticas da Formação Serra Geral. Sobre estas rochas, encontram-se os conglomerados e arenitos do Grupo Bauru, representados na região por arenitos de granulação média, bem graduados, com cerca de $45 \%$ de areia e 35 $\%$ de argila (BORTOLUCCI, 1983). Estas formações podem ser estratigraficamente visualizadas na Figura 3.1 a qual também mostra parte do perfil geológico da região de São Carlos.

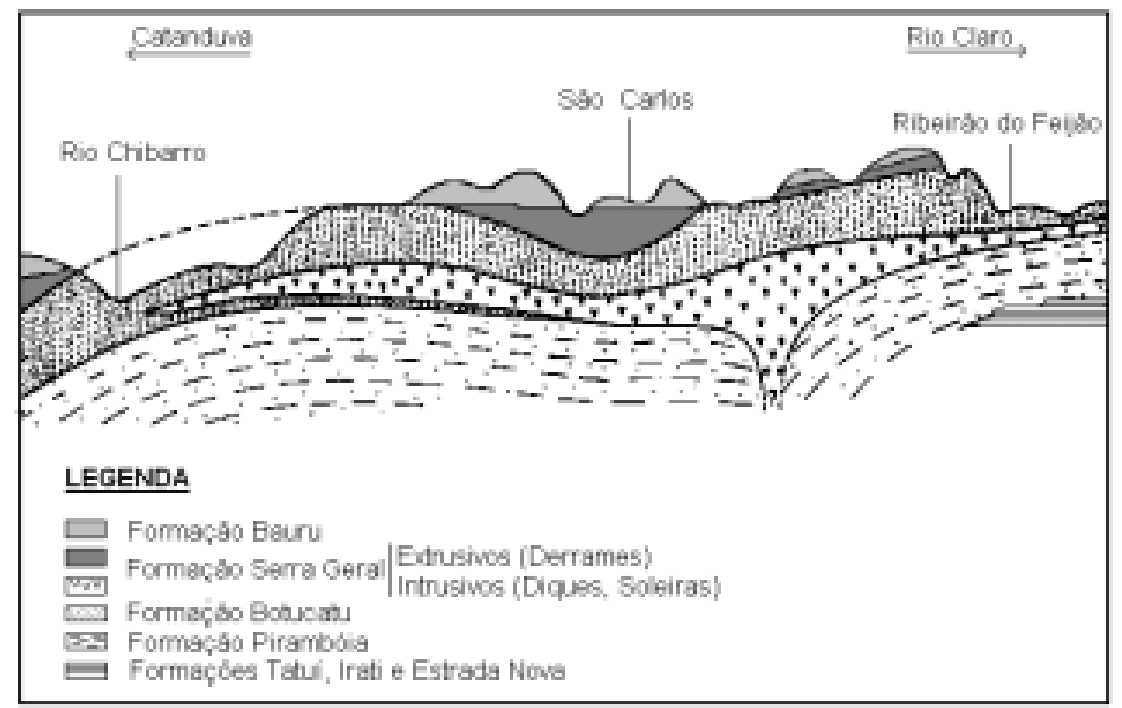

FIGURA 3.1 - Perfil geológico da região de São Carlos (DAEE ${ }^{1}$, apud VILAR, 1979)

1 - DAEE - Depto. de Águas e Energia Elétrica (1974). Estudo de águas subterrâneas -Região administrativa 6. v. 2, 3. 
A ação do intemperismo e da erosão, com posterior retrabalhamento, nos materiais do Grupo Bauru e das Formações Serra Geral e Botucatu originou depósitos superficiais aluviais e coluviais, geologicamente denominados Sedimento Cenozóico. Possuindo grande extensão lateral, recobre quase a totalidade da região centro-oeste do Estado, como pode ser observado na Figura 3.2, e atinge uma espessura não superior a $10 \mathrm{~m}$ na região de São Carlos. Segundo BORTOLUCCI (1983), São Carlos apresenta duas litologias para esse sedimento, sendo a primeira proveniente dos materiais do Grupo Bauru, com uma textura de cerca de $50 \%$ de areia de granulação média a fina e $35 \%$ de argila. A segunda é constituída por sedimentos de basalto e do Grupo Bauru, possuindo $44 \%$ de areia e $40 \%$ de argila. Um fato que comprova a natureza transportada dessa formação é uma característica linha de seixos de quartzo e limonita que a separa da camada do Grupo Bauru.

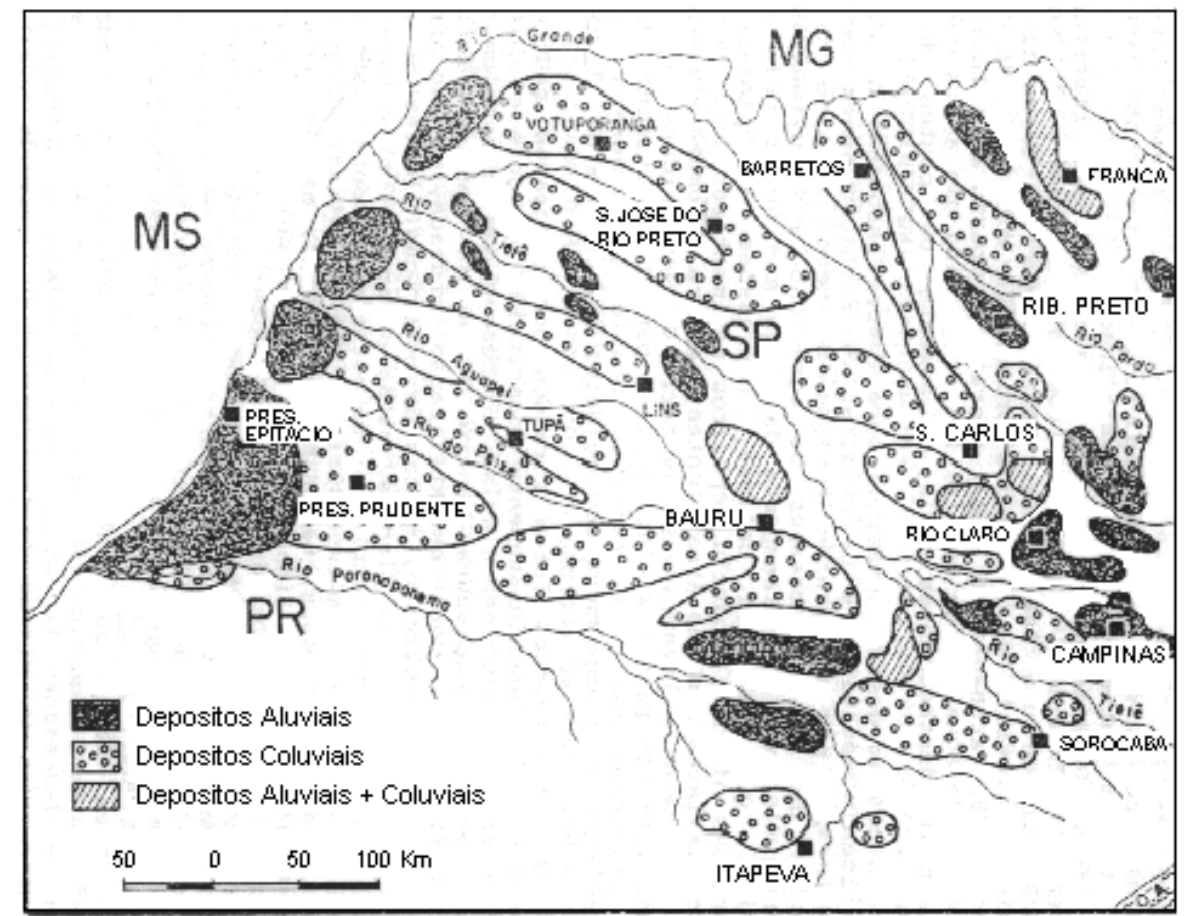

FIGURA 3.2 - Distribuição dos depósitos de cobertura cenozóica do interior do Estado de São Paulo (FÚLFARO \& BJONBERG, 1993)

Um perfil típico da geologia de pequena superfície da área urbana de São Carlos, com descrição das litologias predominantes, é representado na Figura 3.3. 


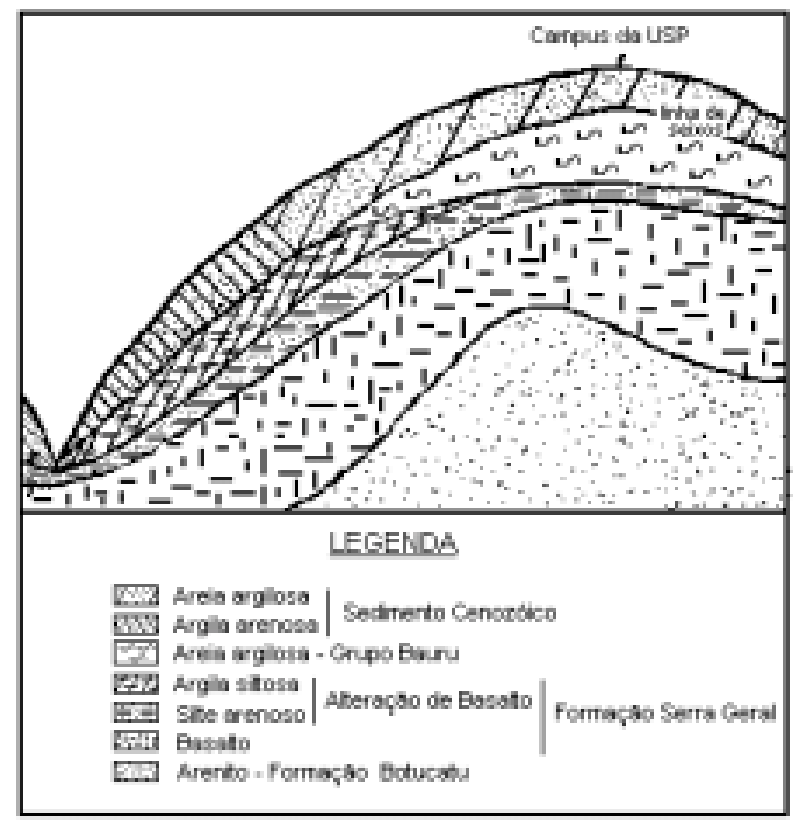

FIGURA 3.3 - Seção esquemática da geologia de pequena profundidade em São Carlos (CINTRA et al., 1991)

\section{2 - CAMPO EXPERIMENTAL DE FUNDAÇÕES}

Implantado em 1988, o Campo Experimental de Fundações, local do desenvolvimento desta pesquisa, está situado no extremo sul do campus da USP/São Carlos, em uma área cujo perfil geológico-geotécnico é considerado representativo da região centro-oeste do Estado de São Paulo (CINTRA et al., 1991). A Figura 3.3 mostra a localização do campus da USP no perfil geológico apresentado.

A área do Campo Experimental foi caracterizada geotecnicamente através de diversos ensaios laboratoriais e in situ, dentre os quais uma campanha de cinco sondagens de simples reconhecimento (SPT) e cinco ensaios de penetração estática (CPT) até a profundidade de $20 \mathrm{~m}$. Um abrangente estudo dos resultados obtidos pode ser verificado em GIACHETI et al. (1993). Posteriormente, uma nova campanha de três sondagens SPT até a profundidade de $28 \mathrm{~m}$ foi executada.

O perfil típico apresenta uma camada superficial colapsível pertencente ao Sedimento Cenozóico, contendo uma areia argilosa marrom, laterizada e porosa. $\mathrm{Na}$ profundidade de aproximadamente $6 \mathrm{~m}$, uma linha de seixos a separa da camada 
subjacente, composta por uma areia argilosa vermelha, relativa ao solo residual do Grupo Bauru. Ambas as camadas são classificadas como uma areia argilosa (SC), de acordo com o Sistema Unificado de Classificação de Solos. A $24 \mathrm{~m}$ de profundidade, encontra-se o solo da Formação Serra Geral, representado por um silte argiloso com fragmentos de rochas basálticas alteradas. O nível do lençol freático atinge uma profundidade de $10 \mathrm{~m}$ no inverno. A Figura 3.4 exibe o perfil típico do Campo Experimental, juntamente com os valores médios obtidos na primeira campanha de ensaios penetrométricos, além dos valores médios de SPT da segunda campanha.

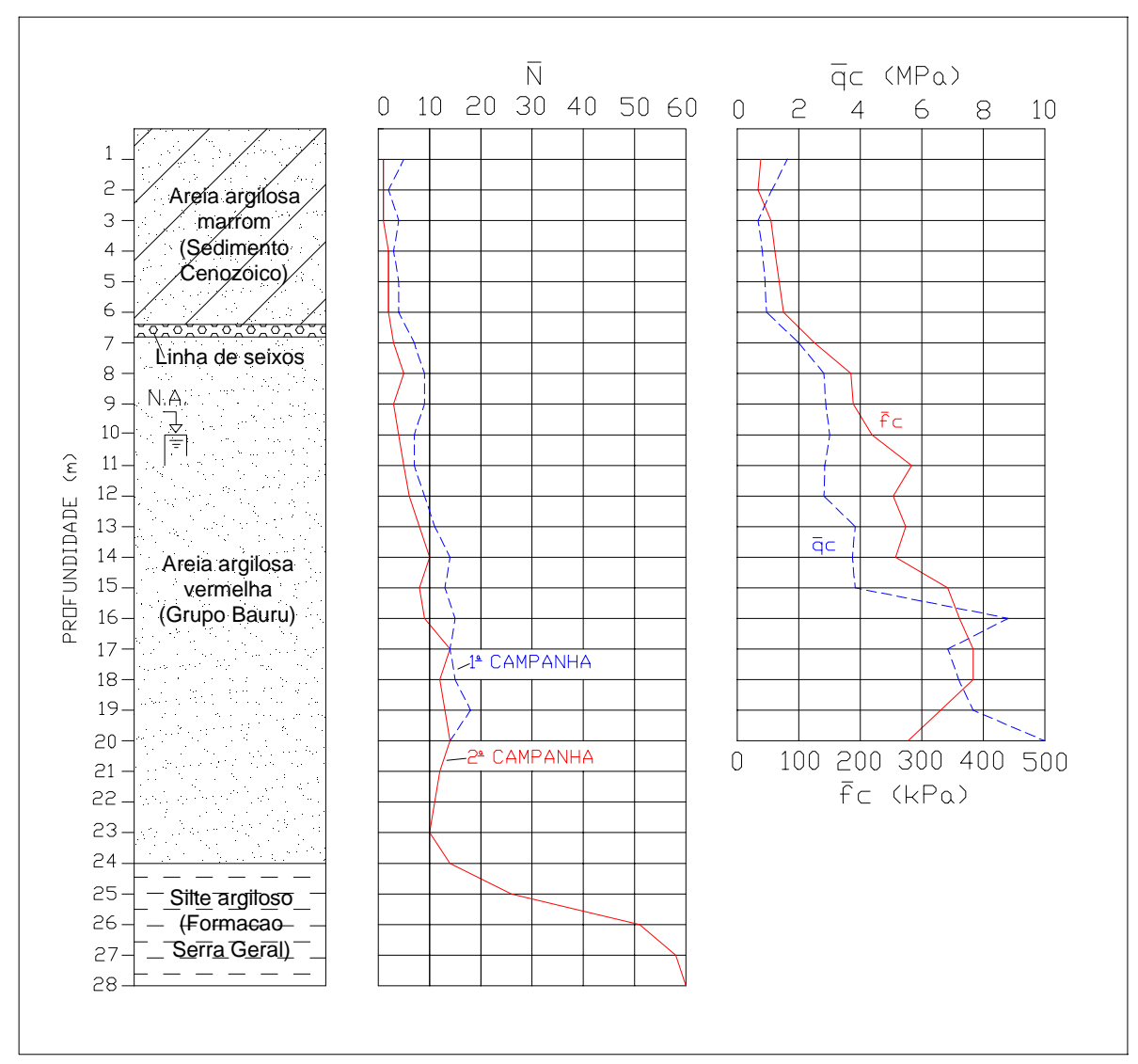

FIGURA 3.4 - Perfil típico do Campo Experimental de Fundações da USP-São Carlos

A Figura 3.5 mostra a variação do peso específico (natural e seco), do índice de vazios e dos limites de consistência com a profundidade, até $9 \mathrm{~m}$. O teor de umidade do solo correspondente ao peso específico natural obtido é também exibido. 


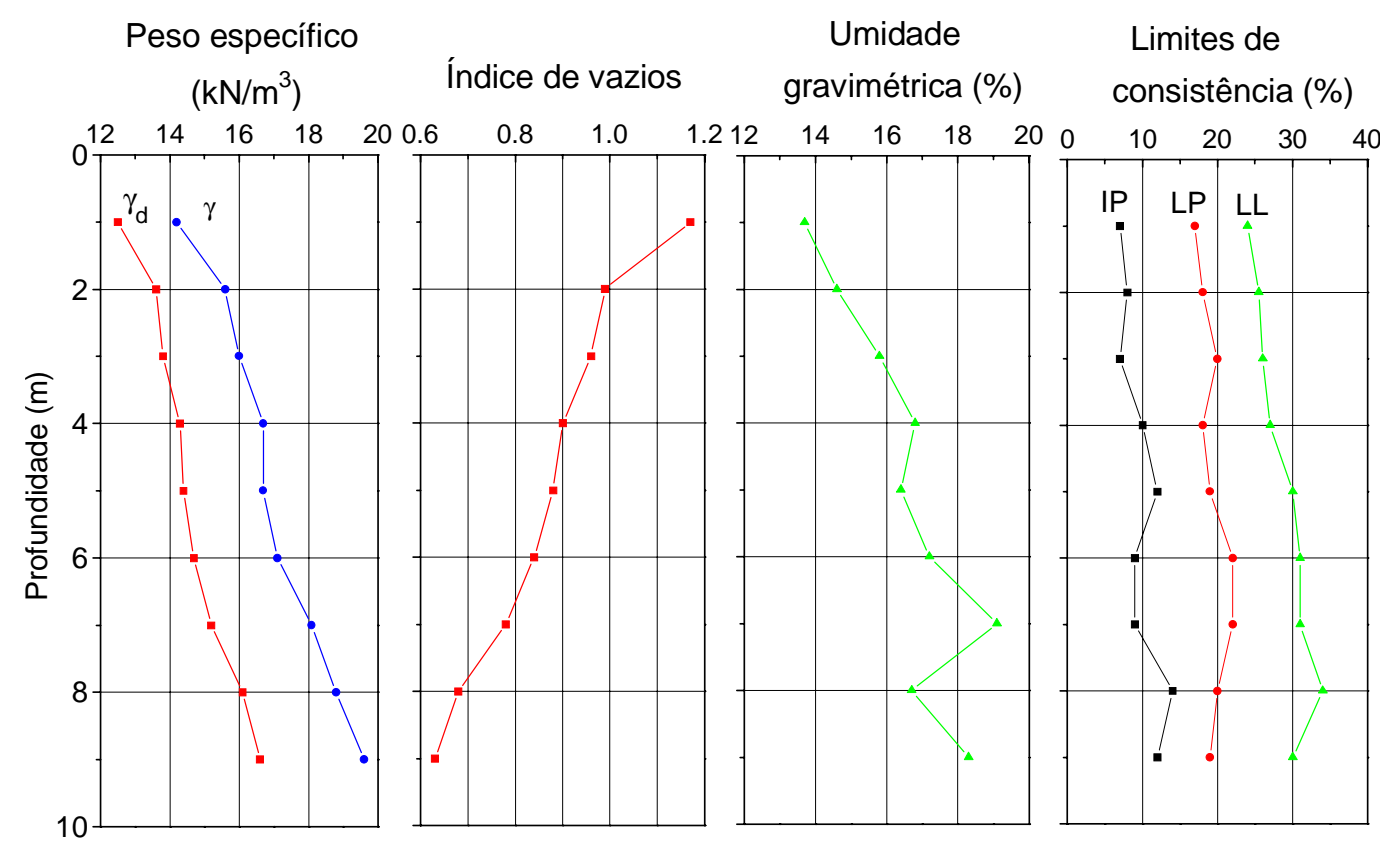

FIGURA 3.5 - Variação de índices físicos e de limites de consistência com a profundidade (Modificado de GIACHETI et al., 1993 e MACHADO, 1998)

A Figura 3.6 apresenta as curvas granulométricas correspondentes às profundidades de 3,5 e $8 \mathrm{~m}$.

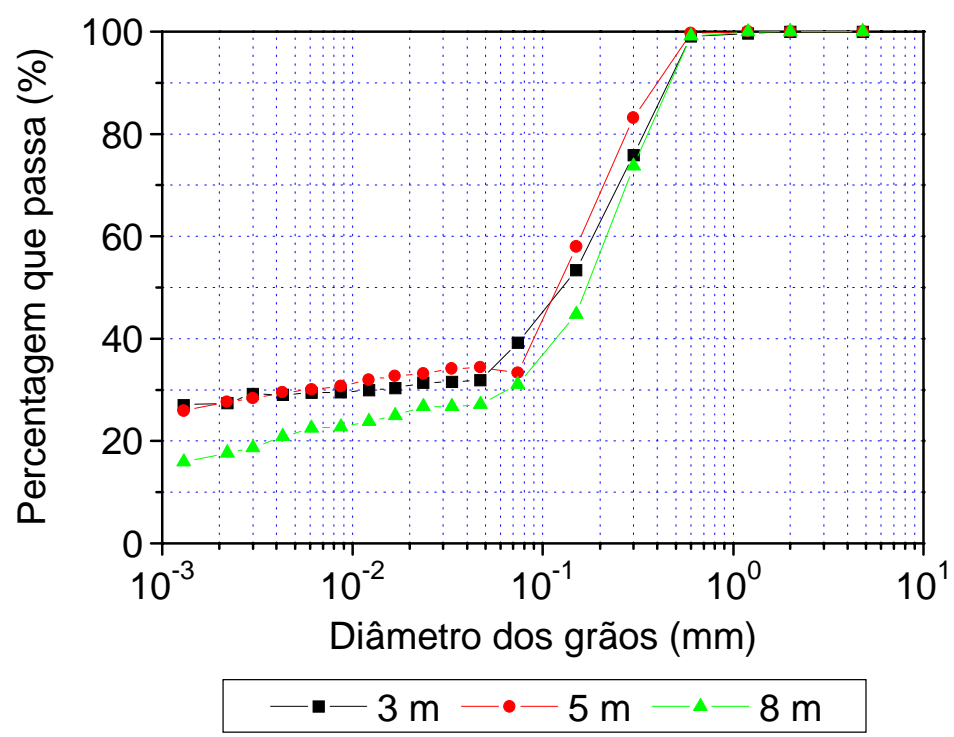

FIGURA 3.6 - Curvas granulométricas obtidas para as profundidades de 3, 5 e 8 m, no Campo Experimental de Fundações (MACHADO, 1998) 
A Tabela 3.1 expõe valores de alguns índices físicos do solo, a serem utilizados neste trabalho em análises posteriores.

TABELA 3.1 - Alguns índices físicos do solo

\begin{tabular}{l|c}
\hline \multicolumn{1}{c|}{ Índice físico } & \\
\hline Peso específico seco $\gamma_{d}\left(\mathrm{kN} / \mathrm{m}^{3}\right)^{1}$ & 13,6 \\
Índice de vazios $e^{1}$ & 0,99 \\
Peso específico dos sólidos $\gamma_{s}\left(\mathrm{kN} / \mathrm{m}^{3}\right)^{2}$ & 27,1 \\
Peso específico seco máximo $\gamma_{d \max }\left(\mathrm{kN} / \mathrm{m}^{3}\right)^{2}$ & 18,7 \\
\hline
\end{tabular}

1 - reproduzido da Figura 3.5, à profundidade de $2 \mathrm{~m}$

2 - obtido de ensaios realizados em amostras extraídas a $3 \mathrm{~m}$ de profundidade 


\section{4 - MATERIAIS E MÉTODOS}

\section{1 - PROVAS DE CARGA EM PLACA}

Foram executadas 14 provas de carga do tipo lenta (SML), rápida (QML) e mista (MML), em placa circular de 0,80 m de diâmetro, assente no terreno a 1,5 m de profundidade.

Realizaram-se oito ensaios com inundação prévia da cava por um período não inferior a 24 horas, assim como quatro ensaios não inundados. Ao término de dois desses últimos, a cava foi inundada igualmente por 24 horas e, em seguida, uma segunda prova de carga foi efetuada (reensaio). A Tabela 4.1 apresenta a seqüência e o tipo de carregamento de cada ensaio. Na Figura 4.1, encontra-se a localização das provas de carga executadas no Campo Experimental de Fundações da USP/São Carlos, sendo identificadas através da ordem cronológica de execução (primeira coluna da Tabela 4.1).

TABELA 4.1 - Seqüência da realização das provas de carga

\begin{tabular}{ccccc}
\hline Prova de Carga n $^{0}$ & Data & Designação & Tipo de carregamento & Estado do solo \\
\hline 1 & $02 / 04 / 98$ & SS1 & Lento & Inundado \\
2 & $18 / 04 / 98$ & QS1 & Rápido & Inundado \\
3 & $24 / 04 / 98$ & MS1 & Misto & Inundado \\
4 & $27 / 05 / 98$ & SS2 & Lento & Inundado \\
5 & $05 / 06 / 98$ & QS2 & Rápido & Inundado \\
6 & $12 / 06 / 98$ & MS2 & Misto & Inundado \\
7 & $24 / 10 / 98$ & Q1 & Rápido & Não inundado \\
8 & $26 / 10 / 98$ & Q1-r* & Rápido & Inundado \\
9 & $09 / 03 / 99$ & S1 & Lento & Não inundado \\
10 & $14 / 03 / 99$ & S1-r* & Lento & Inundado \\
11 & $01 / 04 / 99$ & SS3 & Lento & Inundado \\
12 & $29 / 04 / 99$ & S2 & Lento & Não inundado \\
13 & $16 / 06 / 99$ & MS3 & Misto & Inundado \\
14 & $05 / 07 / 99$ & Q2 & Rápido & Não inundado \\
\hline
\end{tabular}

*Reensaio 


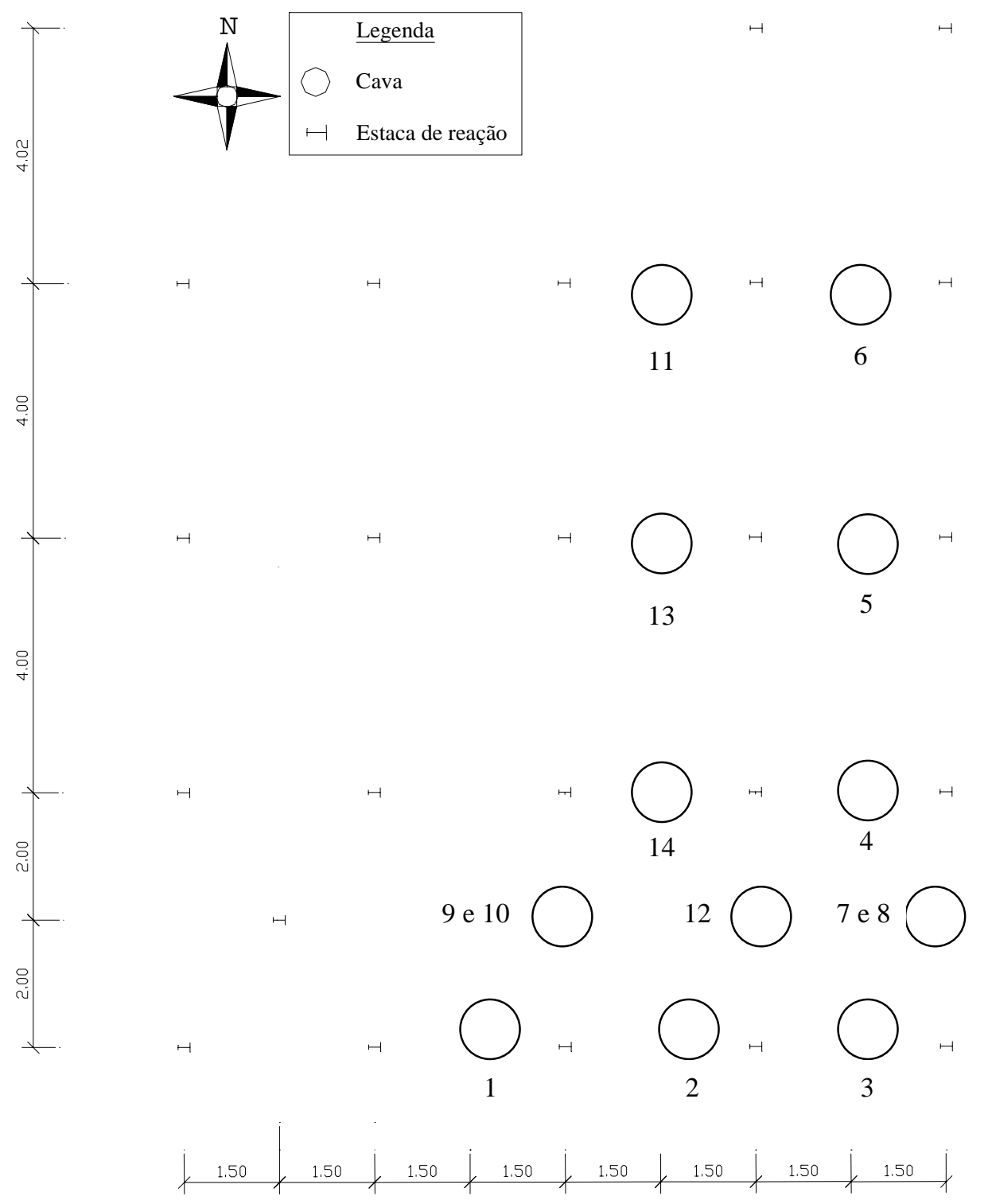

FIGURA 4.1 - Disposição dos ensaios de placa no Campo Experimental da USP/São Carlos

\subsection{1 - Tipos de ensaio realizados}

\section{Ensaios lentos (SML)}

Os ensaios SML foram realizados segundo as prescrições da norma da ABNT NBR 6489/84, com exceção do descarregamento, efetuado em apenas dois estágios. 
Isto se justifica pelo fato deste solo possuir como característica praticamente nenhuma recuperação elástica.

\section{Ensaios rápidos (QML)}

Nos ensaios do tipo rápido (QML), os intervalos de aplicação dos incrementos de carga foram mantidos por 15 minutos em cada estágio, segundo a proposição de FELLENIUS (1975), sendo as leituras dos recalques feitas nos tempos $0,1,2,3,6,9,12$ e $15 \mathrm{~min}$. O descarregamento foi realizado em quatro estágios.

\section{Ensaios mistos (MML)}

Optou-se também pela realização de ensaios denominados "mistos", os quais foram iniciados com aplicações de carregamentos do tipo lento (SML) até um estágio pré-determinado, passando então à utilização de carregamentos do tipo rápido (QML) até o término da prova de carga. A proposição da realização de ensaios mistos remonta a De MELLO (1975), o qual sugeriu uma modificação da versão da época da norma brasileira de prova de carga, para que fosse incluída tal modalidade. Mais recentemente, esta discussão foi reavivada por ALONSO (1997), com referência a provas de carga mista em estacas.

Os ensaios mistos foram realizados segundo as mesmas premissas dos ensaios lentos e rápidos em suas respectivas fases, sendo adotada a tensão admissível provável como critério de mudança do tipo de ensaio. Posteriormente à análise das primeiras provas de carga mistas, achou-se conveniente incluir um segundo requisito: de modo a haver um melhor desenvolvimento da curva tensão-recalque na fase lenta, a mudança do tipo de ensaio somente ocorreria se os deslocamentos tivessem atingido $10 \mathrm{~mm}$. Em cada estágio da fase rápida, o incremento de carga aplicado era igual à metade do incremento empregado nos estágios da fase lenta.

É importante ressaltar que as provas de carga eram levadas até o mais próximo possível do término do curso dos extensômetros $(50 \mathrm{~mm})$ e, em algumas 
delas, recalques maiores ainda foram lidos. Em complementação, em todos os ensaios, antes do início do descarregamento deixou-se de proceder à reposição de carga e aguardou-se a estabilização da mesma e dos recalques.

\subsection{2 - Processo de inundação}

Nas provas de carga em placa, com inundação do terreno, o processo geralmente empregado no Brasil consistia na inundação do solo no estágio correspondente à tensão admissível provável, ou na inundação em diferentes estágios de tensão.

Autores como NADEO \& VIDELA (1975), MELLIOS (1985), SILVA (1990) realizaram provas de carga estática em estacas e REZNIK (1993) em placas, com inundação durante um determinado período antes do início ensaio. No campo Experimental de Fundações da USP/São Carlos, a opção por ensaios previamente inundados foi seguida pela primeira vez por MIGUEL (1996), em provas de carga horizontal em estacas, de acordo com a sugestão de CINTRA (1995). Este procedimento é justificado pelo fato de não se conhecer exatamente a carga na qual o colapso deflagrará, sendo então preferível quantificá-lo a partir de provas de carga com o solo já inundado desde o princípio. Desde então, os trabalhos desenvolvidos neste local que envolvem análise de colapso do solo vêm seguindo este procedimento.

Nas provas de carga em placa deste trabalho, a inundação do solo deu-se mediante a condução de água potável proveniente da rede pública até o fundo da cava por gravidade. Uma lâmina d'água constante de aproximadamente $50 \mathrm{~mm}$ foi mantida no fundo da cava.

\subsection{3 - Tempo de inundação}

O período durante o qual as cavas foram submetidas à inundação foi escolhido de modo a possibilitar a saturação necessária do solo e, por outro lado, de 
forma a atender a questões de disponibilidade de tempo para os ensaios. Assim, considerou-se que um tempo de inundação de $24 \mathrm{~h}$ seria suficiente para o intento do presente trabalho. Posteriormente, a adequabilidade do tempo escolhido foi comprovada através de um ensaio de frente de umedecimento com o uso da técnica de TDR, realizado na cava da prova de carga MS3.

\subsection{4 - Equipamentos e Materiais Utilizados}

\section{Macaco hidráulico e bomba}

Utilizou-se para a execução das provas de carga, um macaco hidráulico com capacidade de aplicação de carga de até $200 \mathrm{kN}$ cujo acionamento era efetuado por uma bomba elétrica. Os carregamentos eram aplicados através do macaco até ser atingida a carga desejada, sendo a mesma mantida durante o estágio. Antes do início de cada ensaio tomava-se o cuidado de recolher o êmbolo do macaco ao máximo, completando a folga com calços de aço, de modo a afastar a possibilidade da falta de curso.

\section{Célula de carga}

Foi utilizada uma célula de carga da marca Transdutec com capacidade de realizar leituras de até 200 kN, cuja curva de calibração encontra-se no Anexo B.

\section{Indicador de deformações}

Para as leituras das deformações específicas dos strain gages instalados na célula de carga, foi empregado um indicador de deformações da marca Transdutec, modelo T832, com resolução de 1 ustrain e capacidade de leitura de \pm 50000 $\mu$ strain. Na execução dos ensaios, posicionava-se no indicador de deformações a leitura equivalente à carga que se pretendia aplicar no estágio. 


\section{Extensômetros mecânicos}

As leituras de recalque foram realizadas mediante o emprego de quatro extensômetros mecânicos da marca Mitutoyo, com resolução de 0,01 mm e curso total de $50 \mathrm{~mm}$. Instalados diametralmente opostos com o auxílio de bases magnéticas articuláveis, a média aritmética de suas leituras permitia a obtenção das medidas de recalques.

Barras de aço com rosca, do tipo Dywidag de $32 \mathrm{~mm}$ de diâmetro, foram utilizadas como elementos de interligação da placa com os extensômetros. Sua fixação era feita por rosqueamento em luvas soldadas diretamente na placa, tornando-se assim suficientemente estáveis. Os extensômetros não eram apoiados diretamente, mas em pequenas placas de azulejo coladas em porcas devidamente rosqueadas na extremidade da barra. O azulejo foi escolhido pelo fato de ser um material que sofre pouquíssimas variações de volume devido a oscilações de temperatura. Na Figura 4.2 observa-se o detalhe da instalação de um dos extensômetros.

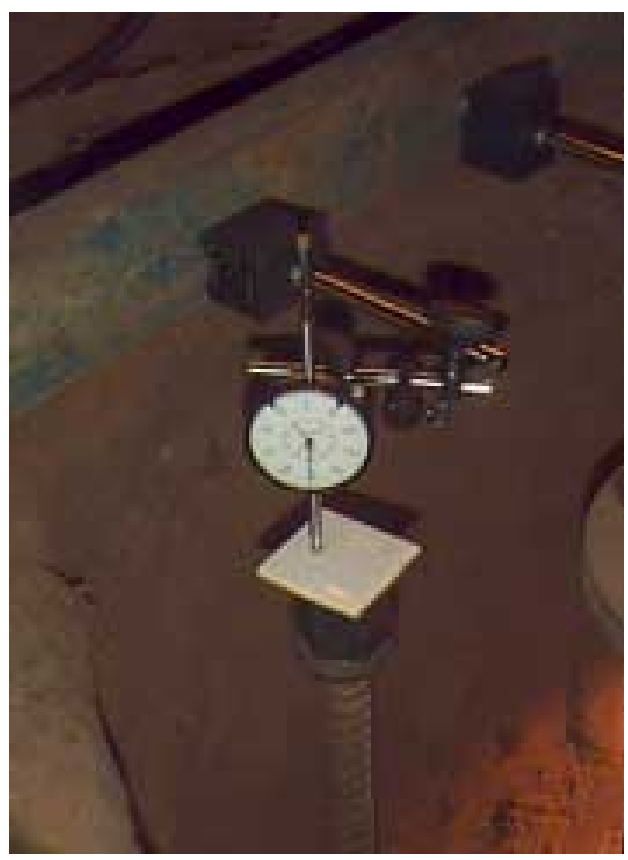

FIGURA 4.2 - Detalhe da instalação de um extensômetro 
Placa

A placa utilizada possui formato circular, confeccionada em aço, com $25 \mathrm{~mm}$ de espessura e $0,80 \mathrm{~m}$ de diâmetro, resultando em uma área de $0,50 \mathrm{~m}^{2}$ de contato com o solo. Para que fosse alcançada uma maior rigidez, foi soldada em sua parte superior uma chapa circular também de aço, com $25 \mathrm{~mm}$ de espessura e $0,30 \mathrm{~m}$ de diâmetro, proporcionando ao conjunto um peso total de aproximadamente $105 \mathrm{~kg}$. A placa pode ser visualizada na Figura 4.8.

\section{Torre de transferência de carga}

Como meio de transferência da carga aplicada pelo macaco hidráulico até a placa foi utilizada uma torre de aço, com tensão admissível à compressão de aproximadamente $100 \mathrm{MPa}$, confeccionada na Oficina Mecânica da USP/São Carlos. A torre é composta por um cilindro de 1,53 m de comprimento, $170 \mathrm{~mm}$ de diâmetro externo e parede de $10 \mathrm{~mm}$ de espessura. De modo a permitir uma melhor distribuição da carga, foram soldados discos circulares de $25 \mathrm{~mm}$ de espessura e 0,30 $\mathrm{m}$ de diâmetro nas extremidades do cilindro, como observado na Figura 4.3, conferindo-lhe um peso total de $80 \mathrm{~kg}$.

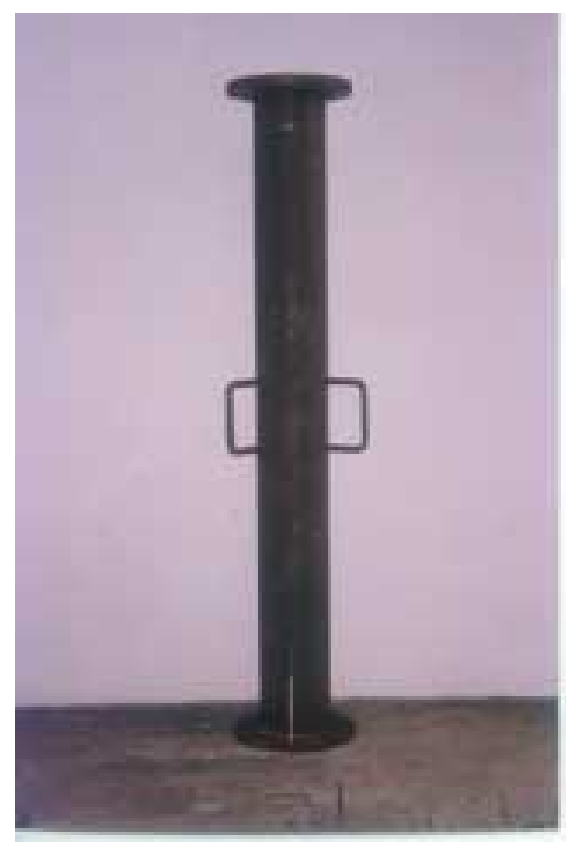

FIGURA 4.3 - Torre de transferência de carga 


\section{Guias de referência}

Como sistema de referência para a medição dos deslocamentos, foram utilizadas duas vigas de aço de 3,3 m de comprimento e com perfil em $\mathrm{U}$, onde eram dispostas as bases magnéticas dos extensômetros. Pontaletes de ferro, cravados no solo até uma profundidade de aproximadamente $0,3 \mathrm{~m}$, distanciados pelo menos 1,5 $\mathrm{m}$ do centro da placa e 1,0 $\mathrm{m}$ do centro das estacas de reação, serviam de apoio para as vigas. Durante a instalação tomou-se o cuidado de não as deixar em contato com o solo, com o intuito de não interferir nos resultados.

\section{Rótula}

Entre a célula de carga e a viga de reação foi utilizada uma rótula de aço para a conservação da normalidade do carregamento.

\section{Barraca}

Após a colocação da placa e montagem de todo o sistema de reação, o local era protegido por uma barraca fabricada em estrutura metálica com fechamento lateral de madeira e cobertura de lona. A Figura 4.4 exibe a barraca utilizada, cuja área era de $4 \times 6 \mathrm{~m}^{2}$.

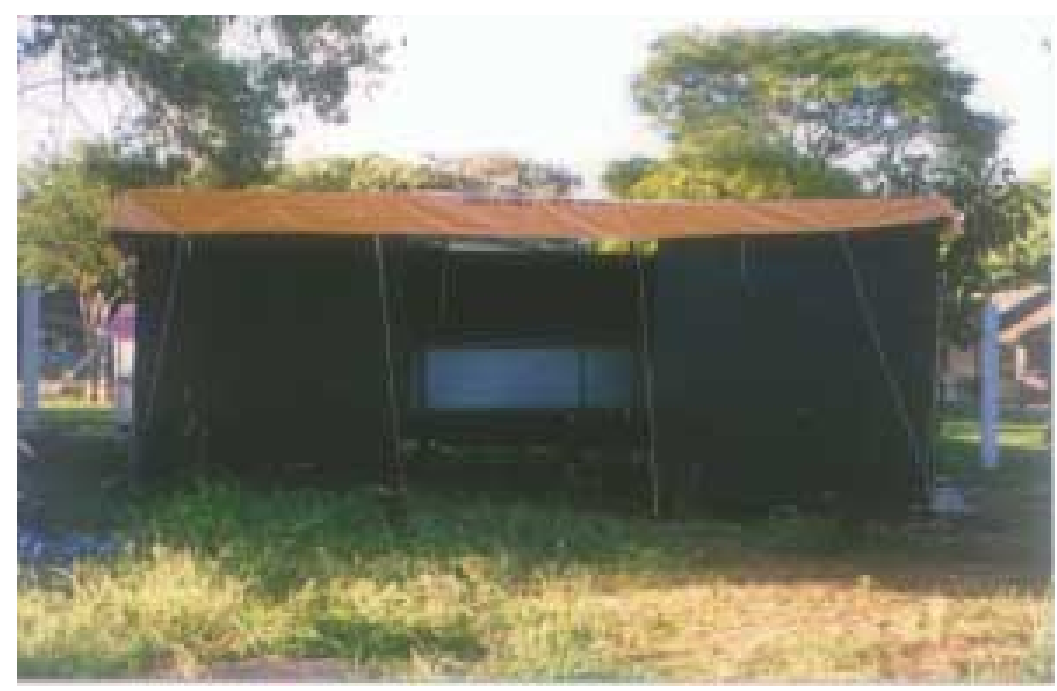

FIGURA 4.4 - Barraca utilizada nas provas de carga 


\subsection{5 - Sistema de Reação}

O sistema de reação era formado por uma viga metálica, a qual transferia a carga aplicada pelo macaco a uma composição de barras do tipo Dywidag (aço protendido ST 85/105) de $32 \mathrm{~mm}$ de espessura. Na seqüência, as barras transmitiam a carga às estacas de reação (metálicas do tipo trilho TR-68, com $27 \mathrm{~m}$ de comprimento e carga admissível a tração de 550 kN).

Dependendo da disposição das cavas em relação às estacas de reação, optavase por uma das duas vigas de reação disponíveis, cujos cortes transversais são apresentados na Figura 4.5. A viga $a$ possui seção transversal em $I$ com $300 \times 650$ $\mathrm{mm}$, comprimento de $3,30 \mathrm{~m}$, capacidade de suporte de $800 \mathrm{kN}$ e peso total de 800 $\mathrm{kg}$. Já a viga $b$, com comprimento de 4,0 m, capacidade de suporte de $2 \mathrm{MN}$ e peso de $2000 \mathrm{~kg}$, é composta por quatro perfis $I$ metálicos. Os perfis centrais são ligados aos laterais por meio de parafusos e, para conferir maior rigidez ao conjunto, quatro barras ligam o centro dos perfis centrais às extremidades dos perfis laterais.

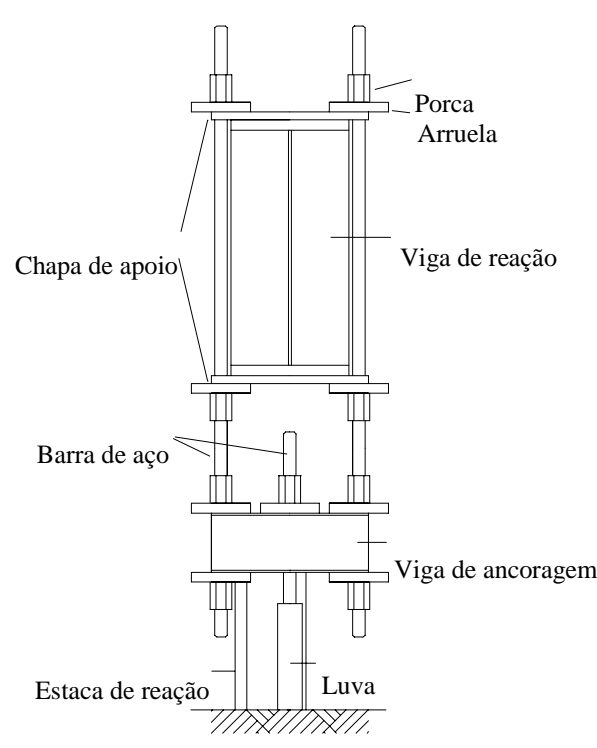

a)

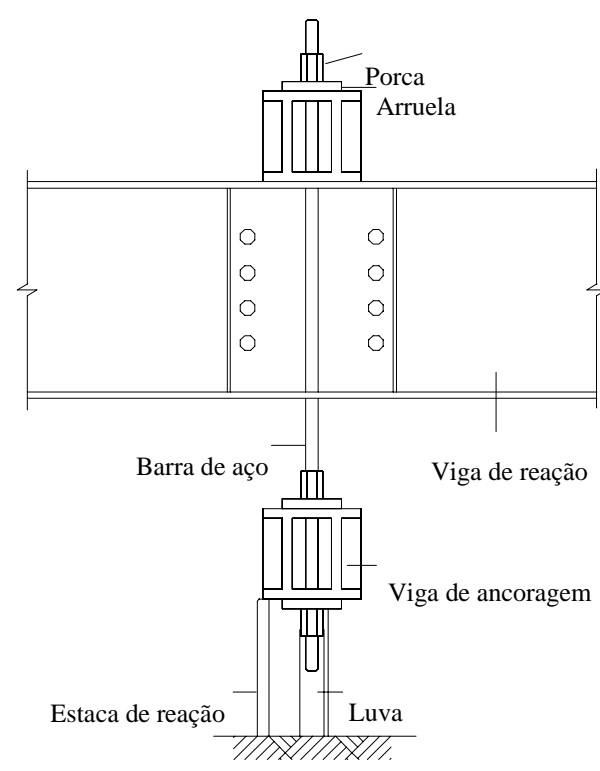

b)

FIGURA 4.5 - Esquemas dos sistemas de reação, vistos em corte transversal 
A Figura 4.6 mostra o esquema geral das provas de carga realizadas, com a disposição dos equipamentos e materiais descritos.

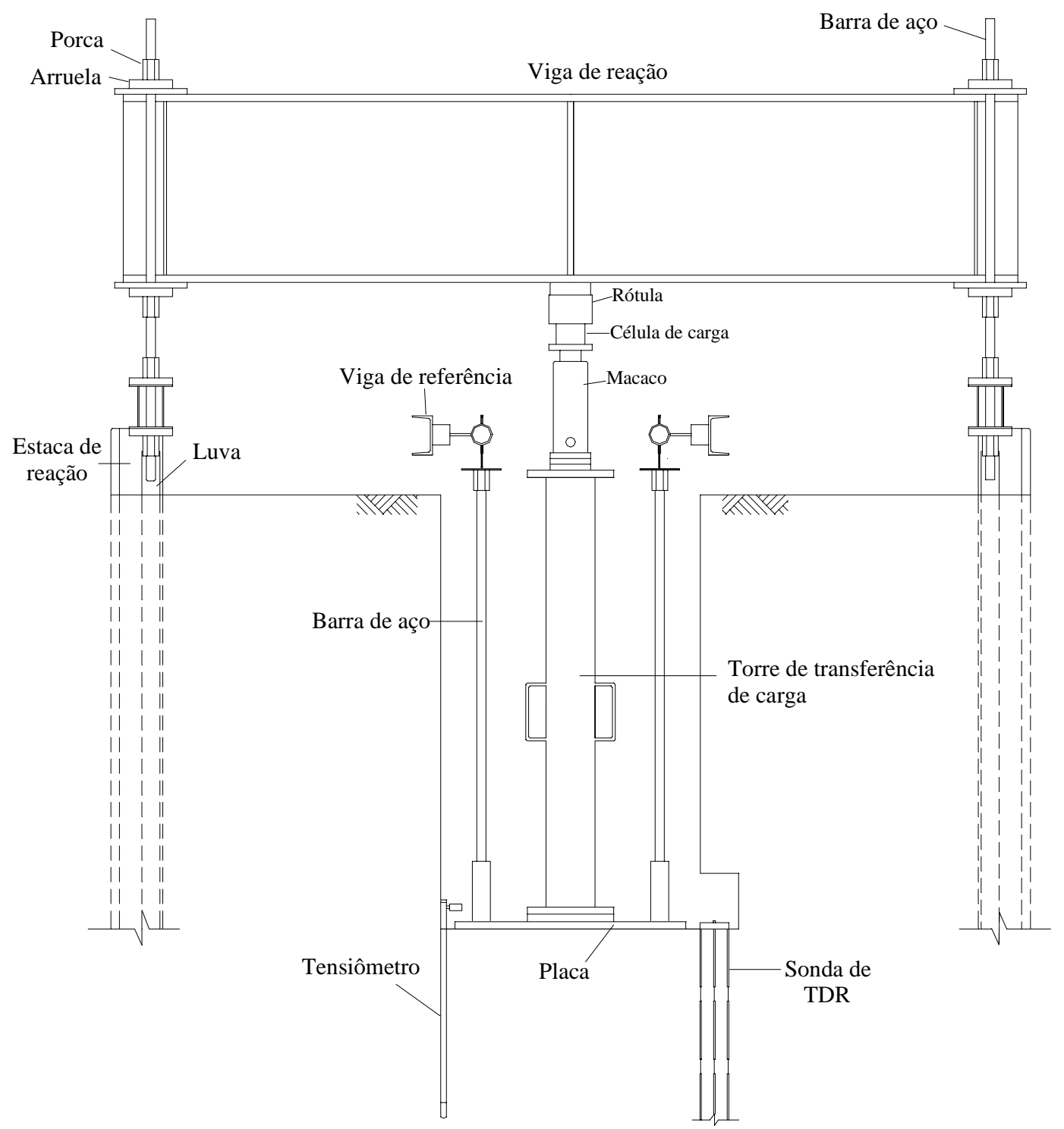

FIGURA 4.6 - Esquema geral das provas de carga realizadas

\section{2 - MEDIDAS DE UMIDADE E SUCÇÃO EM CAMPO}

O teor de umidade e a sucção do solo in situ foram monitorados nas provas de carga através da utilização da técnica de reflectometria no domínio do tempo (TDR), de tensiômetros e da coleta de amostras deformadas. Nas provas de carga não 
inundadas e nos reensaios foram empregadas as três técnicas, ao passo que durante os ensaios com inundação apenas a técnica de TDR foi utilizada.

\subsection{1 - Reflectometria no Domínio do Tempo (TDR)}

Para a realização das medidas de umidade e sucção do solo em campo, através da técnica de TDR, foram empregadas sondas confeccionadas no Departamento de Geotecnia da USP/São Carlos (CARNEIRO \& CONCIANI, 1997). A sondas possuem quatro hastes, segundo o modelo proposto por ZEGELIN et al. (1989). O capacete possui $22 \mathrm{~mm}$ de espessura e $107 \mathrm{~mm}$ de diâmetro, partindo de sua superfície inferior três hastes simetricamente locadas em sua periferia e uma haste central. Espaçadas $50 \mathrm{~mm}$ entre si, as hastes possuem diâmetro de $5 \mathrm{~mm}$ e assim como o capacete, são fabricadas em aço inoxidável. A Figura 4.7 exibe a sonda utilizada.



FIGURA 4.7 - Sonda utilizada

De modo a permitir medidas ao longo de um perfil em diversas profundidades, as sondas empregadas eram também segmentadas (TOPP et al., 1982a, b; TOPP \& DAVIS, 1985). A fim de gerar descontinuidades no sinal, entre os segmentos de $5 \mathrm{~mm}$ de diâmetro foram utilizados segmentos de aço de $50 \mathrm{~mm}$ de 
comprimento e 2,5 mm de diâmetro. Dessa forma, as sondas propiciavam leituras às profundidades de 0,$1 ; 0,3 ; 0,6 ; 0,8$ e $1,1 \mathrm{~m}$ abaixo da cota de assentamento da placa. No entanto, por gerarem resultados não confiáveis de $\varepsilon$, as medições provenientes do último segmento (correspondentes a 1,1 m) foram desconsideradas.

A instalação das sondas era realizada através da cravação das hastes por prensagem, com o auxílio de um guia de madeira para manter constante o espaçamento. Resumidamente, os seguintes passos foram seguidos na instalação: colocação do guia de madeira; cravação de cada segmento de haste; retirada do guia de madeira e colocação do capacete. No fundo de cada cava foram cravadas duas antenas quando os ensaios eram realizados com sucção diferente de zero, ao passo que, para aqueles ensaios com inundação prévia, apenas uma foi utilizada. A Figura 4.8 exibe as sondas instaladas dentro da cava.

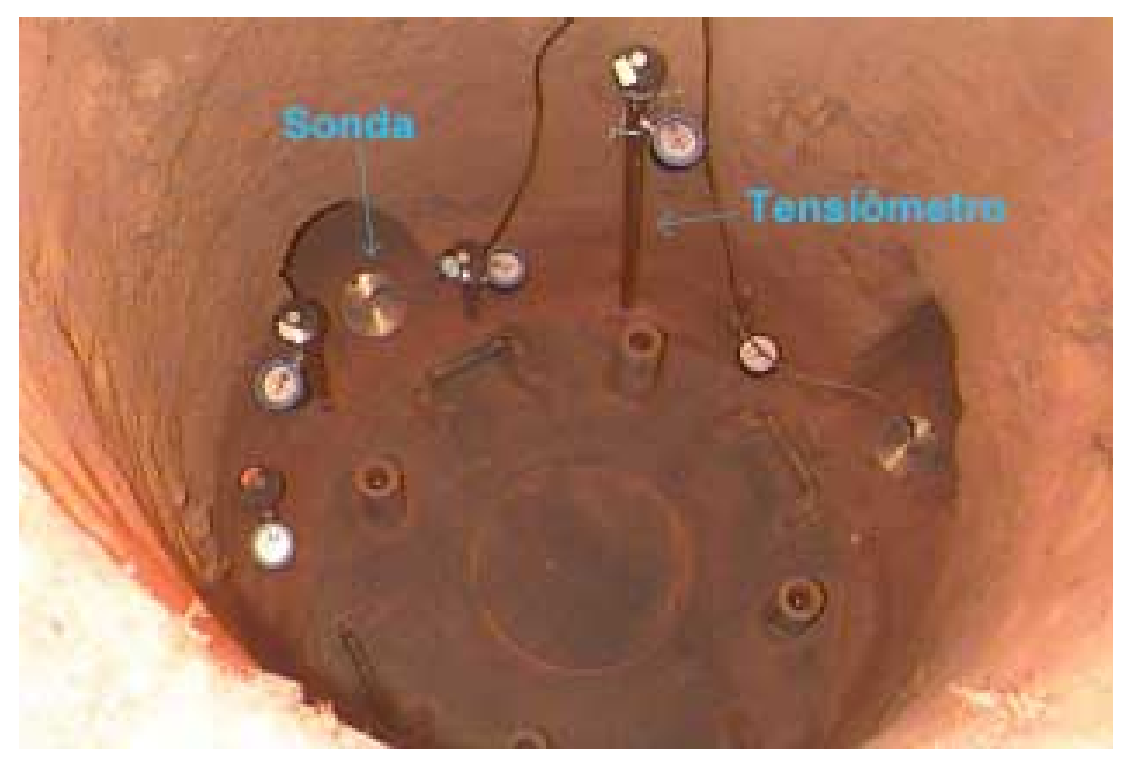

FIGURA 4.8 - Disposição das sondas de TDR, dos tensiômetros e da placa dentro da cava

Para a leitura dos sinais foi utilizado um testador de cabos da marca Tektronix, modelo 1502C (Figura 4.9). Este equipamento mede o tempo de resposta de uma onda eletromagnética de velocidade conhecida, retornando o comprimento do meio de propagação, chamado “comprimento virtual”. Conhecendo-se o 
comprimento da sonda lido no aparelho, a constante dielétrica do solo é calculada de acordo com a equação 4.1 .

$\varepsilon=\left(\frac{\mathrm{S}_{\mathrm{TDR}}}{\mathrm{v}_{\mathrm{P}} \mathrm{L}}\right)^{2}$

onde:

$\mathrm{S}_{\mathrm{TDR}}$ - comprimento da linha de transmissão lido no aparelho;

$\mathrm{V}_{\mathrm{P}}$ - velocidade de propagação do sinal na linha de transmissão, dada como uma percentagem da velocidade da luz no vácuo;

$\mathrm{L}$ - comprimento real da sonda.

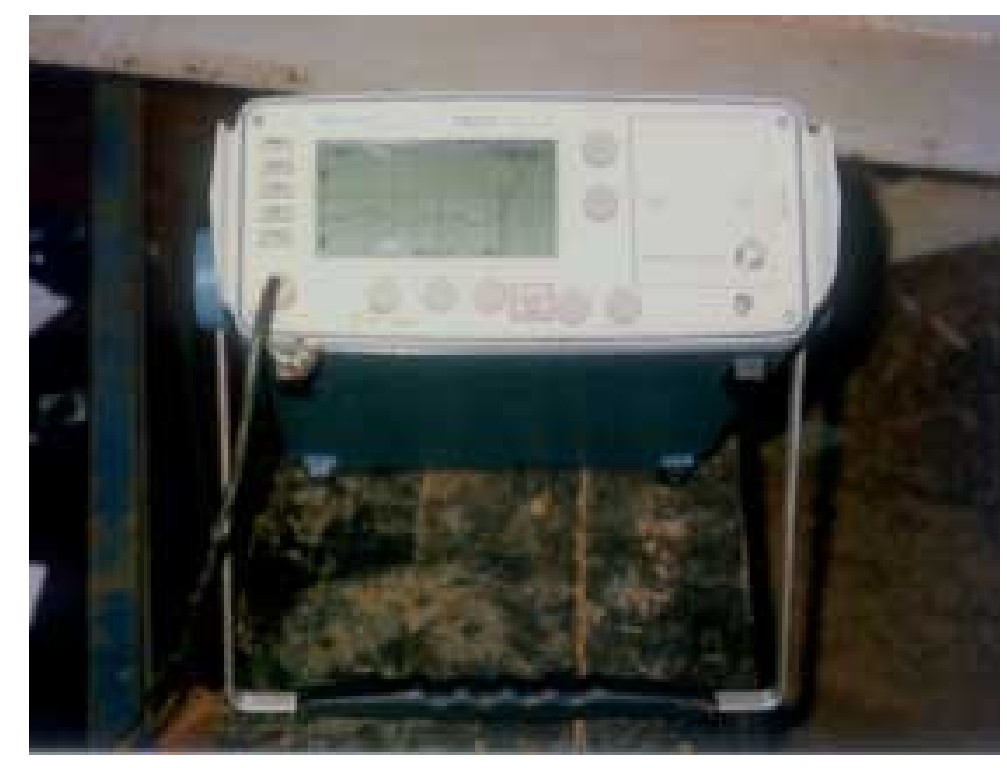

FIGURA 4.9 - Testador de cabos utilizado

Como elemento de ligação entre o testador de cabos e a sonda, foi utilizado um cabo coaxial de polietileno com impedância de $50 \Omega$. Sua conexão era feita através de um conector do tipo BNC. Os cabos coaxiais encaixam-se adequadamente neste propósito porque possuem a propriedade de confinar o sinal transmitido, prevenindo perdas.

Em algumas provas de carga, o sinais fornecidos pelo testador de cabos foram gravados em um computador laptop para posterior análise. Para tanto foi utilizada uma interface serial denominada SP232, também de fabricação da Tektronix. 


\subsection{2 - Tensiometria}

Foram utilizados tensiômetros da marca Soil Moisture, munidos de medidores de pressão negativa da água do tipo vacuômetro Bourdon. Com diâmetro externo de aproximadamente $20 \mathrm{~mm}$, possuíam também a característica de serem do tipo "Jet Fill", ou seja, providos de um reservatório no topo que facilita a complementação do nível de água no tubo, além de auxiliar na eliminação de bolhas. Sua cápsula porosa possui uma permeabilidade de $10^{-5} \mathrm{~cm} / \mathrm{s}$. Empregados em número de cinco em cada prova de carga, os aparelhos foram instalados em profundidades equivalentes às de medida dos sinais de $\operatorname{TDR}(0,1 ; 0,3 ; 0,6 ; 0,8$ e $1,1 \mathrm{~m})$. A disposição destes aparelhos dentro da cava pode ser vista na Figura 4.8.

Anteriormente à instalação, o tensiômetro era devidamente examinado. Inicialmente, realizava-se uma inspeção visual à procura de possíveis fraturas na cápsula porosa. Em seguida, com o tensiômetro cheio, media-se a pressão apresentada pelo vacuômetro, estando sua cápsula porosa mergulhada numa vasilha com água para verificar se o mesmo apresentaria a medida correspondente à coluna d'água. As eventuais bolhas de ar presas dentro do tubo eram retiradas ao máximo, previamente à instalação, com o auxílio de uma bomba de vácuo portátil.

A instalação do tensiômetro era procedida mediante a utilização de um trado com diâmetro ligeiramente inferior ao do tubo. Nos últimos centímetros, a cravação era conduzida por prensagem, visando a garantia do contato do elemento poroso com o solo.

\subsection{3 - Retirada de amostras deformadas}

Antes do início e após o término dos ensaios conduzidos com o solo no teor de umidade natural, amostras do solo do fundo da cava eram coletadas e acondicionadas em sacos plásticos, destinadas à determinação do teor de umidade gravimétrica. Este serviço era realizado com o auxílio de um trado helicoidal que as 
retirava ao longo de um perfil vertical nas profundidades de 0,$1 ; 0,3 ; 0,6 ; 0,8$ e $1,1 \mathrm{~m}$ abaixo da cota do fundo da cava.

\section{3 - ENSAIOS DE LABORATÓRIO PARA CORRELACIONAR CONSTANTE DIELÉTRICA, UMIDADE VOLUMÉTRICA E SUCÇÃO}

Com o objetivo de correlacionar valores de constante dielétrica $\varepsilon$ do solo com valores de umidade volumétrica $\theta$ e de sucção $\left(\mathrm{u}_{\mathrm{a}}-\mathrm{u}_{\mathrm{w}}\right)$, foram construídas em laboratório curvas de calibração de $\varepsilon$ versus $\theta$ e $\varepsilon$ versus $\left(\mathrm{u}_{\mathrm{a}}-\mathrm{u}_{\mathrm{w}}\right)$, obtidas pelo ramo de secagem dos corpos de prova.

Para a realização do processo, uma amostra indeformada foi extraída à profundidade de 1,5 m no Campo Experimental, sendo então talhado e inserido um corpo de prova em uma célula coaxial, que nada mais é do que uma sonda como a descrita anteriormente com algumas modificações. Em vez das três hastes periféricas, possui um anel cilíndrico de $100 \mathrm{~mm}$ de altura, $70 \mathrm{~mm}$ de diâmetro interno e 2,5 $\mathrm{mm}$ de espessura. O capacete, de $85 \mathrm{~mm}$ de diâmetro, é perfurado para permitir a adição de água na amostra. A Figura 4.10 apresenta uma célula coaxial desmontada.

Já dentro da célula coaxial, o corpo de prova foi devidamente umedecido até atingir seu máximo grau de saturação. Após pesagem e obtenção de $\varepsilon$, o mesmo foi então levado à estufa (à temperatura de $105^{\circ} \mathrm{C}$ ) para ter o teor de umidade reduzido. Em seguida, novas medidas de peso e de teor de umidade foram realizadas. Repetiuse o processo até que se obtivesse um número razoável de pontos $(\varepsilon ; \theta)$.

A construção da curva $\varepsilon$ versus $\left(\mathrm{u}_{\mathrm{a}}-\mathrm{u}_{\mathrm{w}}\right)$ deu-se através do uso de um equipamento denominado Câmara de Richards, confeccionado no Departamento de Geotecnia da USP/São Carlos e apresentado na Figura 4.11. Após pesagem e obtenção da constante dielétrica, a célula coaxial contendo o corpo de prova inicialmente saturado foi inserida na câmara. A sucção desejada era aplicada através 
da elevação da pressão de ar, sendo a pressão da água mantida igual a zero (técnica de translação de eixos de Hilf). Verificada a constância de peso do corpo de prova, que em geral ocorria entre uma e duas semanas, novas medidas de peso e constante dielétrica eram tomadas para, em seguida, a sucção ser aumentada. Os valores de sucção utilizados no ensaio foram de 10, 20, 30, 50, 75, 100, 200 e $300 \mathrm{kPa}$.

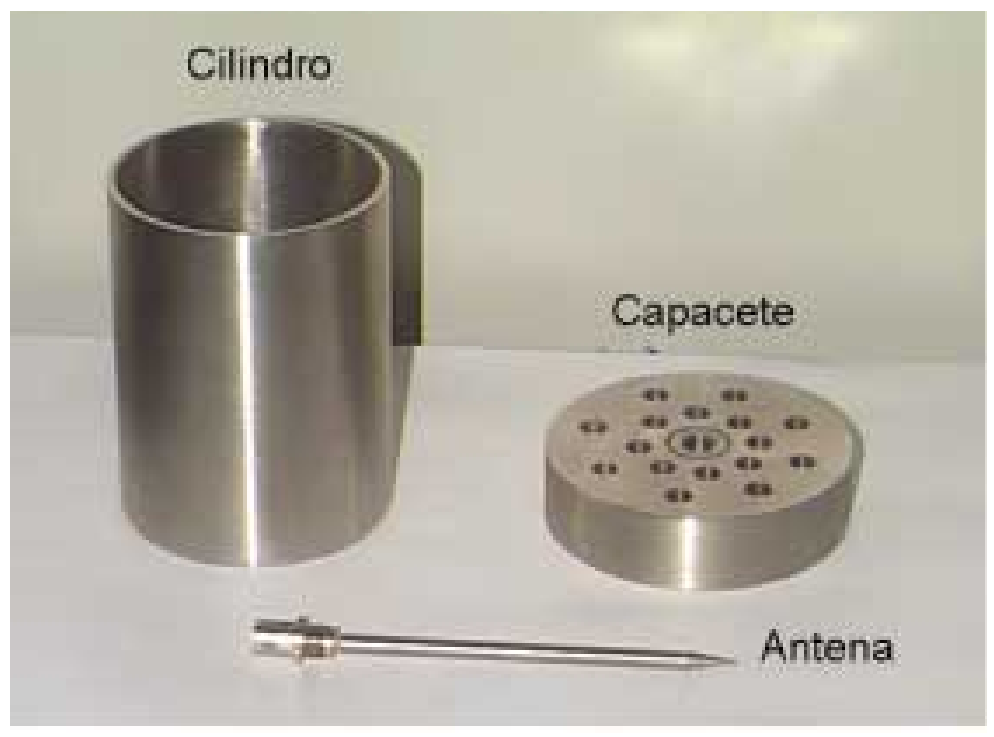

FIGURA 4.10 - Célula coaxial desmontada

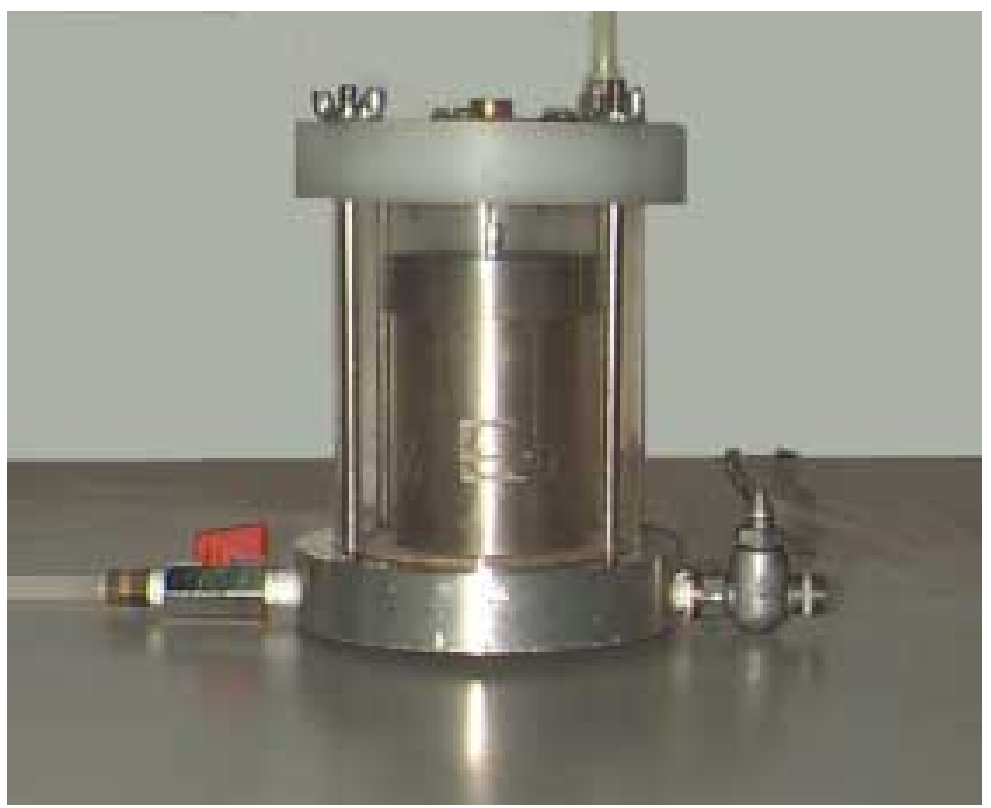

FIGURA 4.11- Corpo de prova dentro da Câmara de Richards confeccionada no Departamento de Geotecnia da USP/São Carlos 


\section{5 - APRESENTAÇÃO DOS RESULTADOS}

Neste capítulo são apresentados os resultados referentes às provas de carga em placa e às medidas de teor de umidade e sucção in situ através das técnicas citadas no capítulo anterior.

\section{1 - CURVAS TENSÃO-RECALQUE}

São exibidas nas Figuras 5.1, 5.2 e 5.3 as curvas tensão-recalque concernentes à série de provas de carga realizadas com inundação prévia do solo, agrupadas de acordo com o tipo de ensaio.

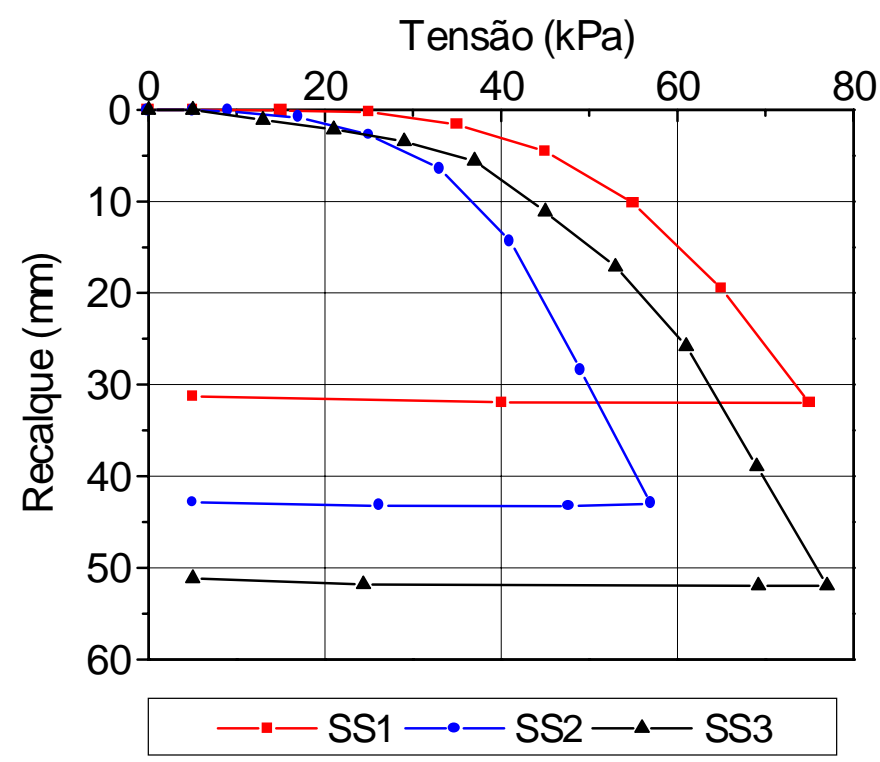

FIGURA 5.1 - Curvas tensão-recalque dos ensaios SML inundados 


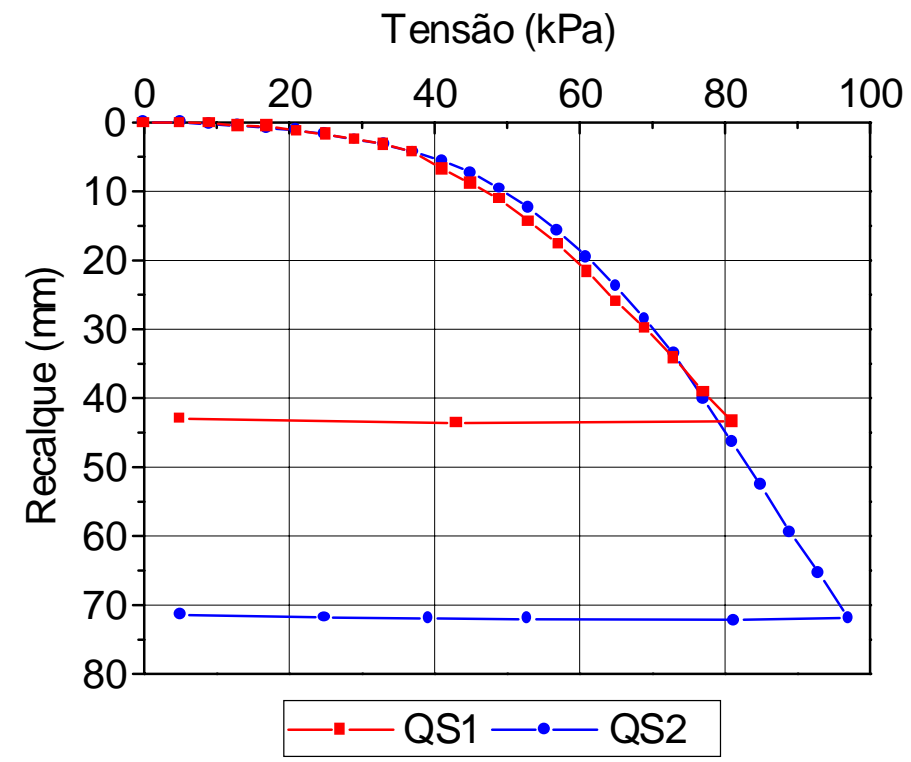

FIGURA 5.2 - Curvas tensão-recalque dos ensaios QML inundados

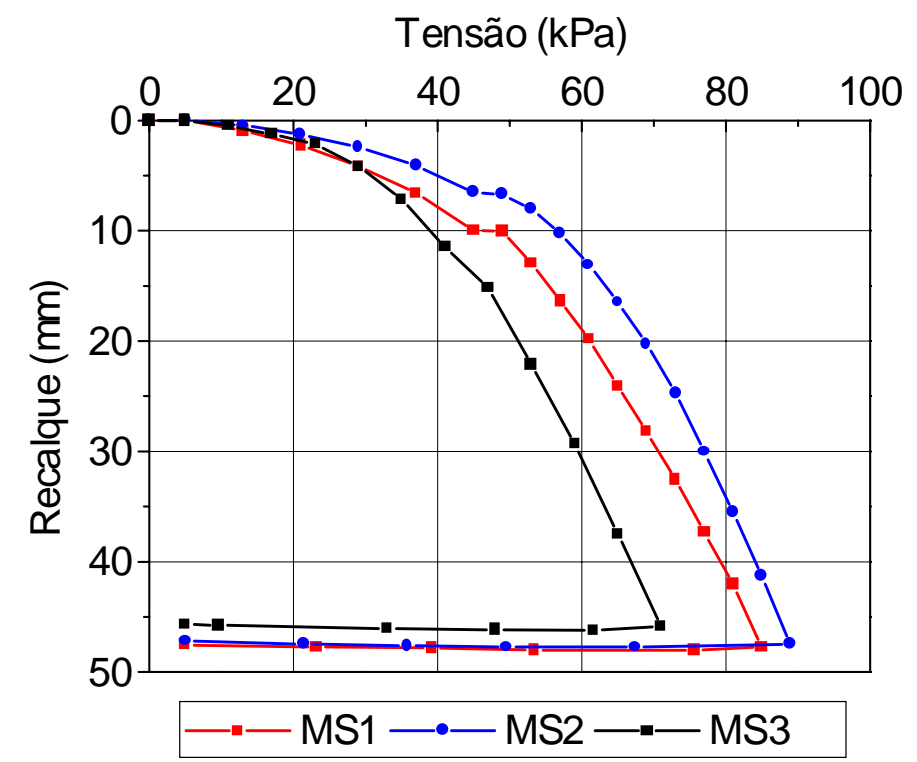

FIGURA 5.3 - Curvas tensão-recalque dos ensaios MML inundados

As Figuras 5.4 e 5.5 apresentam, respectivamente, as curvas dos ensaios não inundados S1 e Q1, juntamente com as de seus reensaios, seguindo a seqüência 
evolutiva dos recalques. As Figura 5.6 e 5.7 ilustram os resultados dos ensaios não inundados $\mathrm{S} 2$ e Q2, respectivamente.

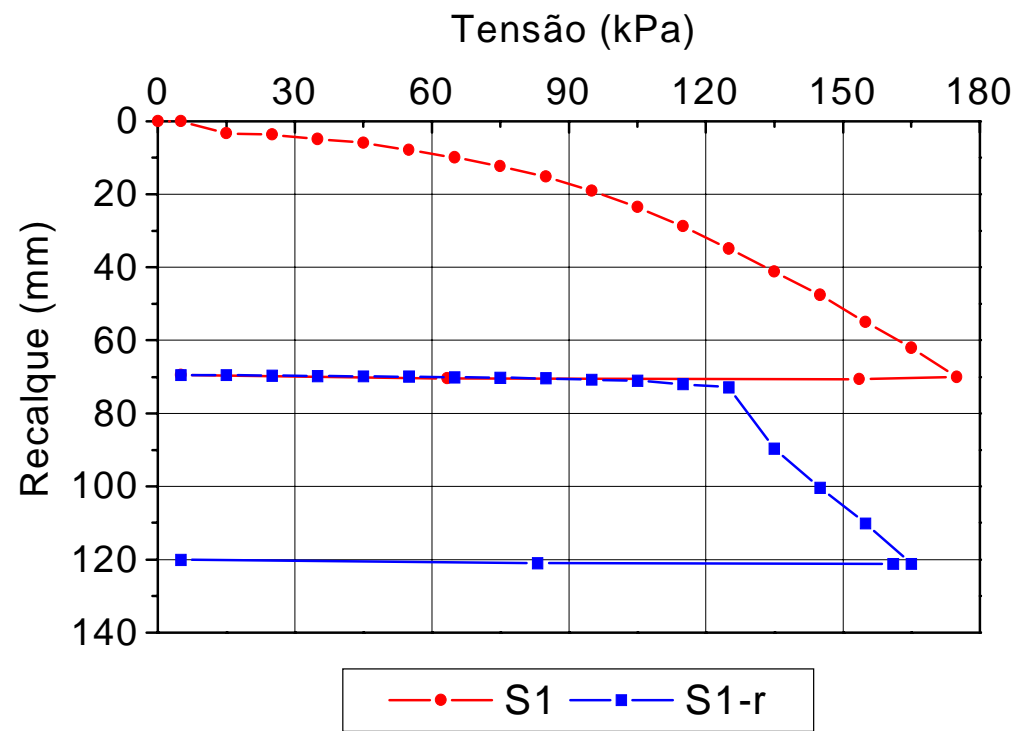

FIGURA 5.4 - Curvas tensão-recalque de S1 e S1-r. Recalques acumulados

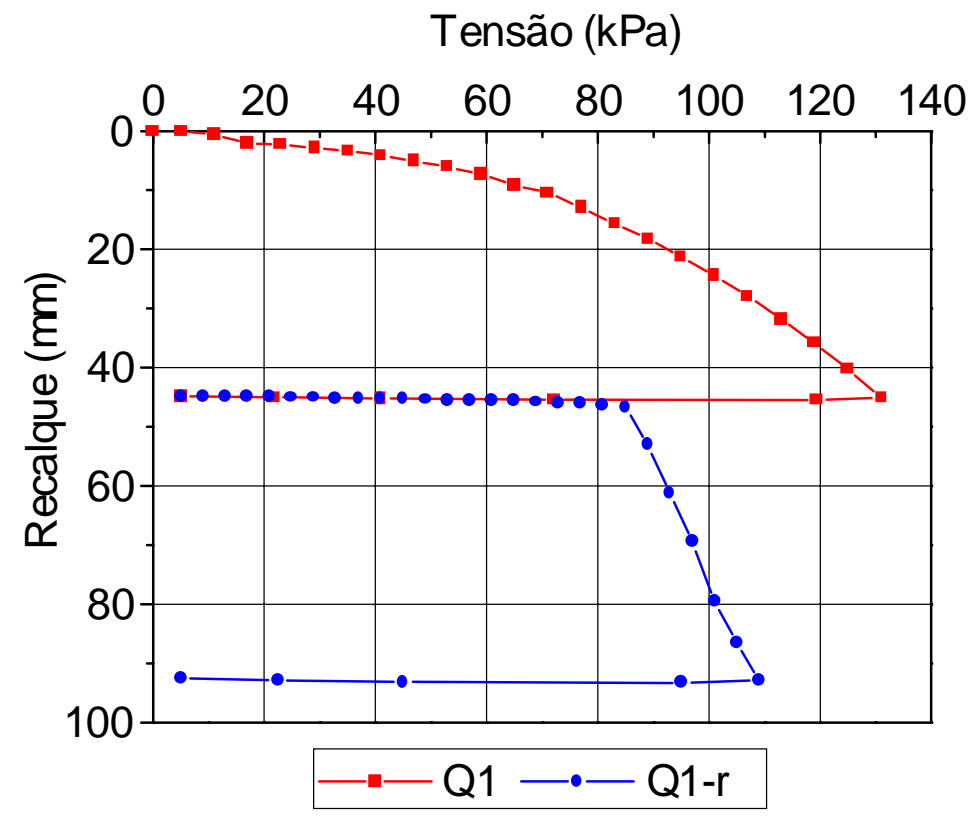

FIGURA 5.5 - Curvas tensão-recalque de Q1 e Q1-r. Recalques acumulados 


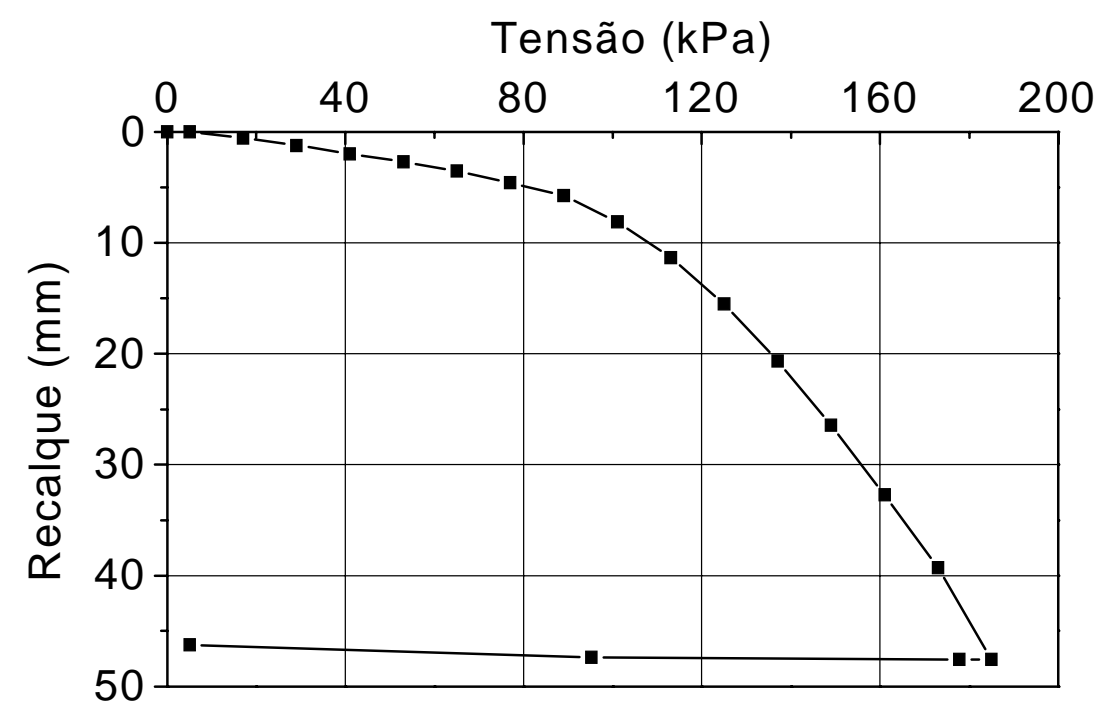

FIGURA 5.6 - Curva tensão-recalque de S2

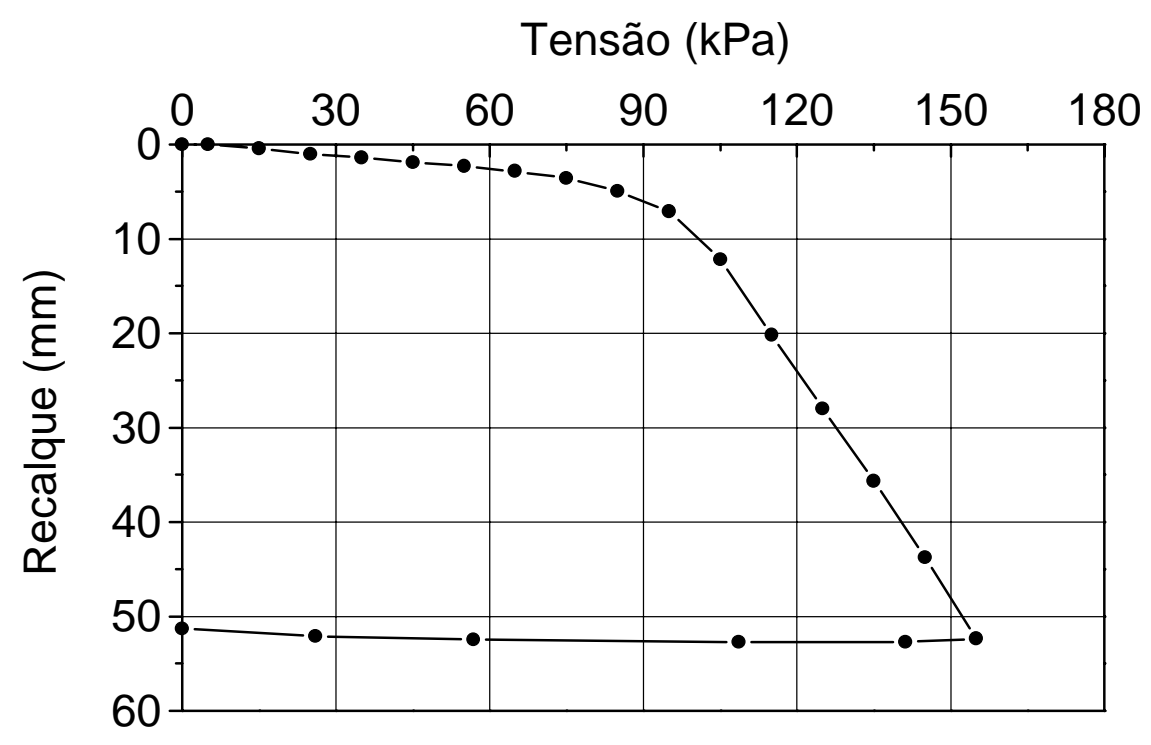

FIGURA 5.7 - Curva tensão-recalque de Q2

As curvas tensão versus recalque inicial e estabilizado de todas as provas de carga encontram-se no Anexo A. 


\section{2 - CORRELAÇÕES ENTRE CONSTANTE DIELÉTRICA, UMIDADE VOLUMÉTRICA E SUCÇÃO}

\subsection{1 - Constante dielétrica e umidade volumétrica}

A Figura 5.8 apresenta os resultados dos ensaios laboratoriais realizados com o objetivo de correlacionar a constante dielétrica com a umidade volumétrica do solo. Nessa figura, $\theta$ é traçado em função de $\varepsilon$, sendo os dados ajustados através da equação 5.1, um polinômio do quinto grau, com $\mathrm{R}^{2}=0,99$.

$$
\theta=1,096 \cdot 10^{-4} \varepsilon^{5}-8,183 \cdot 10^{-3} \varepsilon^{4}+2,304 \cdot 10^{-1} \varepsilon^{3}-3,045 \varepsilon^{2}+20,477 \varepsilon-38,435
$$

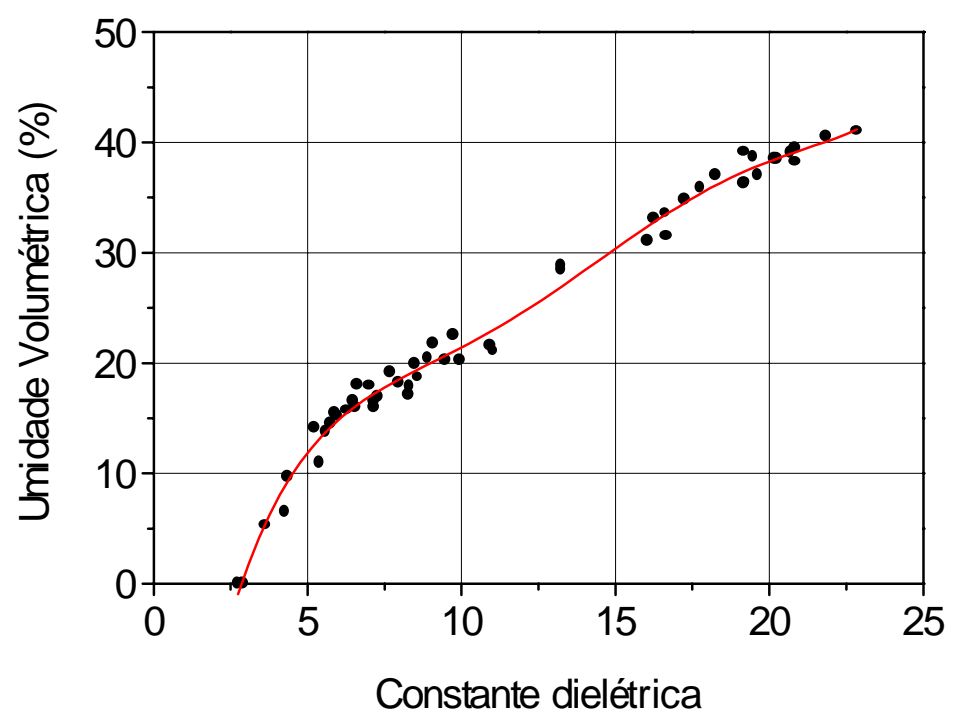

FIGURA 5.8 - Correlação entre constante dielétrica e umidade volumétrica

\subsection{2 - Constante dielétrica e sucção}

Na Figura 5.9 são exibidos os resultados dos ensaios conduzidos com o objetivo de correlacionar a constante dielétrica com a sucção matricial do solo. Os dados foram ajustados com o auxílio da equação 5.2, com $\mathrm{R}^{2}=0,96$. 


$$
\left(u_{\mathrm{a}}-\mathrm{u}_{\mathrm{w}}\right)=\frac{13,08}{1-0,41 \cdot \varepsilon+0,04 \cdot \varepsilon^{2}}
$$

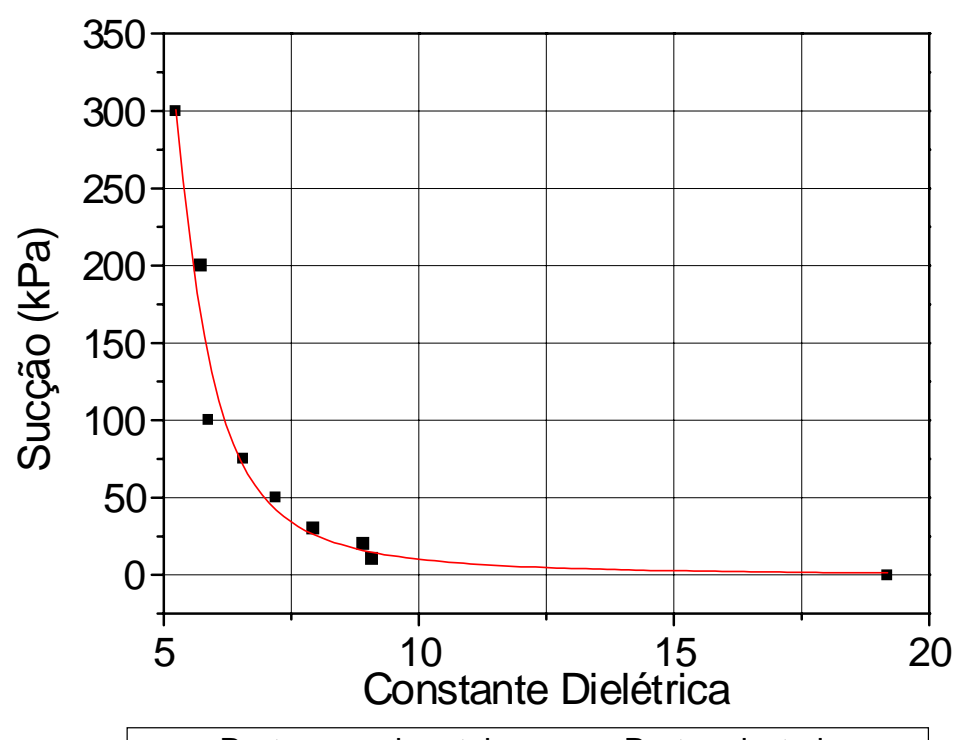

- Pontos experimentais — Pontos ajustados

FIGURA 5.9 - Correlação entre constante dielétrica e sucção

A Figura 5.10 apresenta a curva característica do solo, construída a partir de valores de $\left(\mathrm{u}_{\mathrm{a}}-\mathrm{u}_{\mathrm{w}}\right)$ e $\theta$, apresentados nas figuras 5.8 e 5.9. Um ajuste aos pontos experimentais através da proposição de FREDLUND \& XING (1994) é também exibido na mesma figura, sendo a seguinte equação utilizada para tanto:

$$
\theta=53,8\left[1-\frac{\ln \left(1+\frac{\left(\mathrm{u}_{\mathrm{a}}-\mathrm{u}_{\mathrm{w}}\right)}{20000}\right)}{\ln \left(1+\frac{1000000}{20000}\right)}\right]\left[\frac{1}{\ln \left(\mathrm{e}+\frac{\left(\mathrm{u}_{\mathrm{a}}-\mathrm{u}_{\mathrm{w}}\right)}{0,32}\right)^{1,20}}\right]^{0,63}
$$




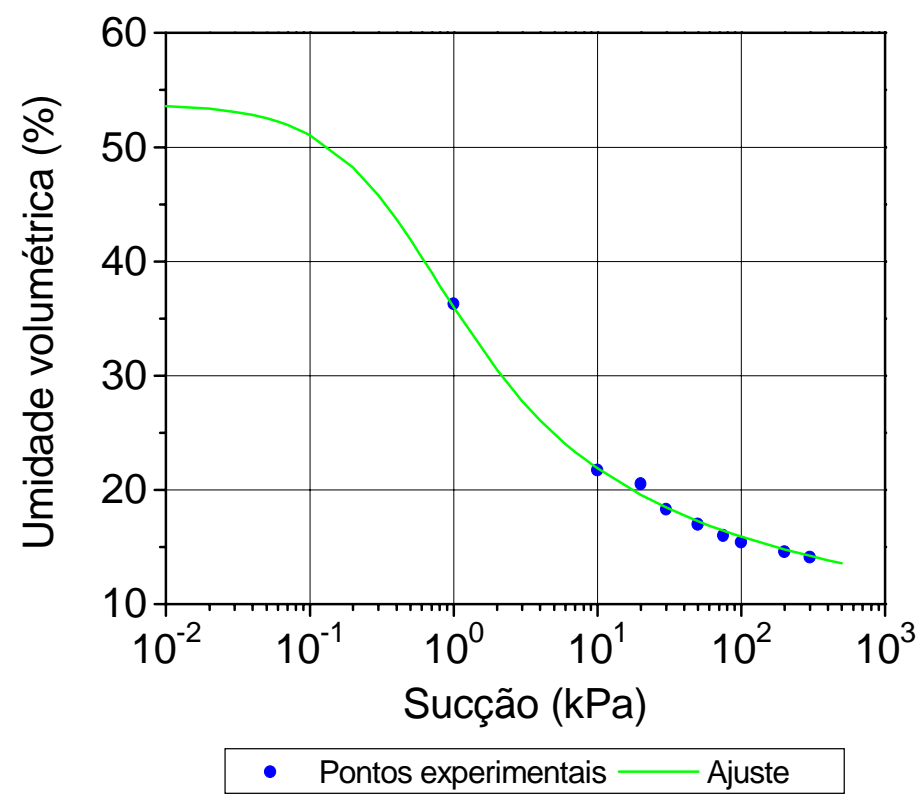

FIGURA 5.10 - Curva característica do solo

\section{3 - MEDIDAS DE TEOR DE UMIDADE E SUCÇÃO EM CAMPO}

\subsection{1 - Reflectometria no Domínio do Tempo (TDR)}

A partir de leituras de $\varepsilon$, tornou-se possível obter medidas do teor de umidade e da sucção no campo através da técnica de TDR, durante as provas de carga, com o auxílio das equações 5.1 e 5.2, respectivamente. Para cada profundidade de leitura do sinal, a Tabela 5.1 apresenta valores médios de teor de umidade volumétrica obtidos durante as provas de carga com inundação. Nessa e nas tabelas subsequentes, os números entre parênteses referem-se aos correspondentes desvios padrões. 
TABELA 5.1 - Valores de umidade volumétrica (\%) das provas de carga com inundação

\begin{tabular}{c|cccc}
\cline { 2 - 5 } \multicolumn{1}{c|c}{} & \multicolumn{4}{|c}{ Profundidade $(\mathrm{m})$} \\
\cline { 1 - 4 } Prova de Carga & 0,1 & 0,3 & 0,6 & 0,8 \\
\hline SS1 & $37,0(1,3)$ & $39,1(0,5)$ & $33,9(1,2)$ & $42,4(0,8)$ \\
SS2 & $38,1(0,6)$ & $39,1(0,3)$ & $39,3(0,5)$ & $40,7(1,7)$ \\
SS3 & $35,4(1,9)$ & $38,0(2,9)$ & $35,3(1,8)$ & $32,5(1,9)$ \\
QS1 & $33,7(1,2)$ & $34,8(1,9)$ & $38,6(0,6)$ & $38,5(0,7)$ \\
QS2 & $43,0(0,9)$ & $40,7(0,2)$ & $41,0(1,0)$ & - \\
MS1 & $38,0(1,9)$ & $37,7(4,9)$ & $37,8(2,7)$ & $38,0(0,4)$ \\
MS2 & $39,0(0,5)$ & $39,1(0,4)$ & $39,7(0,8)$ & $40,4(1,9)$ \\
MS3* & $41,9(0,6)$ & $34,7(0,8)$ & $34,6(0,7)$ & $33,7(1,2)$ \\
S1-r* & $36,6(2,0)$ & $39,5(0,7)$ & $39,7(0,5)$ & $41,4(1,0)$ \\
Q1-r & $39,3(0,3)$ & $30,1(2,6)$ & $30,1(1,5)$ & $30,5(0,9)$ \\
\hline * Provas de carga com gravação do sinal de TDR & &
\end{tabular}

Da mesma forma, a Tabela 5.2 apresenta valores médios de sucção matricial obtidos de leituras realizadas durante as provas de carga com inundação.

TABELA 5.2 - Valores de sucção $(\mathrm{kPa})$ das provas de carga com inundação

\begin{tabular}{c|cccc}
\cline { 2 - 5 } & \multicolumn{4}{|c}{ Profundidade $(\mathrm{m})$} \\
Prova de Carga & 0,1 & 0,3 & 0,6 & 0,8 \\
\hline SS1 & $1,4(0,3)$ & $1,1(0,1)$ & $2,0(0,3)$ & $0,8(0,0)$ \\
QS1 & $2,0(0,3)$ & $1,8(0,3)$ & $1,2(0,1)$ & $1,2(0,1)$ \\
MS1 & $1,3(0,3)$ & $1,5(0,7)$ & $1,4(0,4)$ & $1,5(0,1)$ \\
SS2 & $1,3(0,1)$ & $1,1(0,0)$ & $1,1(0,1)$ & $1,0(0,2)$ \\
QS2 & $0,8(0,0)$ & $0,9(0,0)$ & $0,9(0,1)$ & - \\
MS2 & $1,1(0,1)$ & $1,1(0,1)$ & $1,0(0,1)$ & $1,0(0,2)$ \\
SS3 & $1,7(0,3)$ & $1,3(0,4)$ & $1,7(0,3)$ & $2,3(0,4)$ \\
MS3 & $0,8(0,0)$ & $1,8(0,1)$ & $1,8(0,1)$ & $2,0(0,2)$ \\
Q1-r & $1,5(0,1)$ & $2,5(0,4)$ & $3,0(0,3)$ & $3,1(0,2)$ \\
S1-r & $1,3(0,2)$ & $0,9(0,1)$ & $1,4(0,1)$ & $0,9(0,1)$ \\
\hline
\end{tabular}

As Tabelas 5.3 e 5.4 apresentam, respectivamente, valores médios de umidade volumétrica e sucção obtidos ao longo das provas de carga não inundadas. 
TABELA 5.3 - Valores de umidade volumétrica (\%) das provas de carga não inundadas

\begin{tabular}{c|cccc}
\cline { 3 - 5 } \multicolumn{1}{c|}{} & \multicolumn{4}{|c}{ Profundidade $(\mathrm{m})$} \\
\cline { 1 - 4 } Prova de carga & 0,1 & 0,3 & 0,6 & 0,8 \\
\hline S1* & $19,5(0,3)$ & $23,8(0,5)$ & $24,3(0,4)$ & $29,1(0,5)$ \\
S2* & $18,8(0,2)$ & $19,5(0,3)$ & $20,4(0,1)$ & $21,9(0,3)$ \\
Q1 & $20,2(1,1)$ & $20,7(0,2)$ & $21,2(0,7)$ & $24,3(1,0)$ \\
Q2* & $18,6(0,2)$ & $18,3(0,2)$ & $20,9(0,4)$ & $22,8(0,5)$ \\
\hline
\end{tabular}

* Provas de carga com gravação do sinal de TDR

TABELA 5.4 - Valores de sucção $(\mathrm{kPa})$ das provas de carga não inundadas

\begin{tabular}{c|cccc}
\cline { 3 - 5 } & \multicolumn{4}{|c}{ Profundidade (m) } \\
\cline { 3 - 5 } Prova de carga & 0,1 & 0,3 & 0,6 & 0,8 \\
\hline S1 & $19,0(1,9)$ & $7,0(0,7)$ & $5,8(0,4)$ & $3,1(0,2)$ \\
S2 & $23,0(1,5)$ & $18,5(1,8)$ & $13,5(0,6)$ & $9,2(0,6)$ \\
Q1 & $15,8(5,0)$ & $13,2(2,6)$ & $11,5(2,4)$ & $6,0(1,0)$ \\
Q2 & $29,9(2,8)$ & $34,2(2,7)$ & $12,7(1,3)$ & $8,7(1,1)$ \\
\hline
\end{tabular}

A partir das Tabelas 5.3 e 5.4, pôde-se construir perfis de variação da umidade e da sucção com a profundidade para os ensaios não inundados, como exposto nas Figuras 5.11 e 5.12.

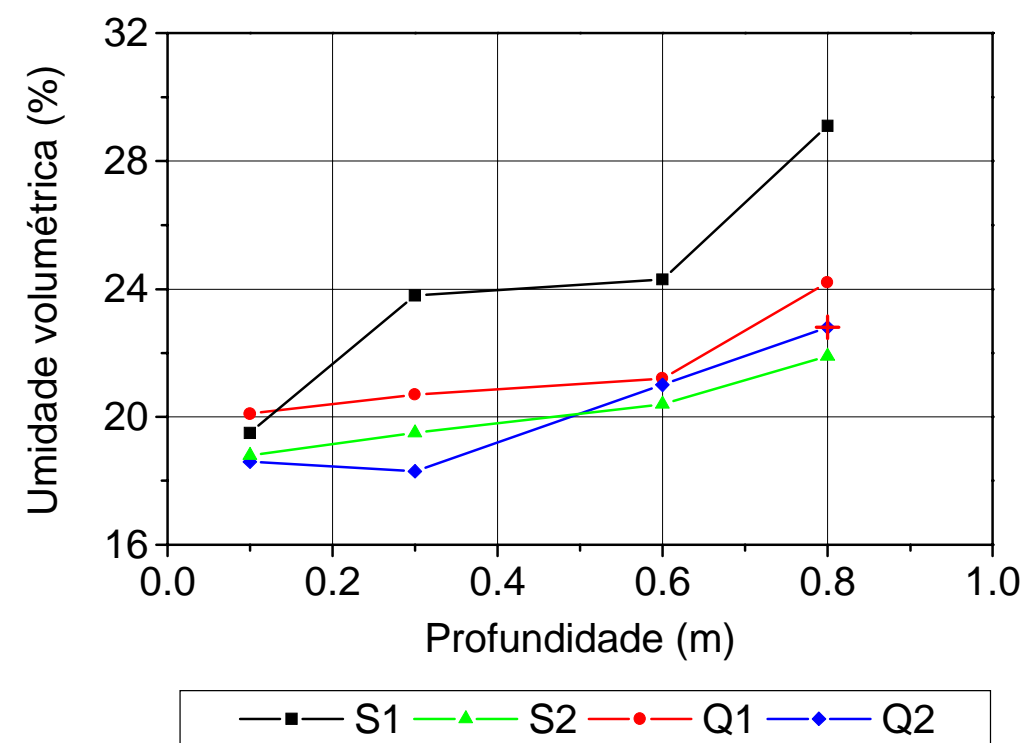

FIGURA 5.11 - Variação da umidade volumétrica com a profundidade nas provas de carga não inundadas. Técnica de TDR 

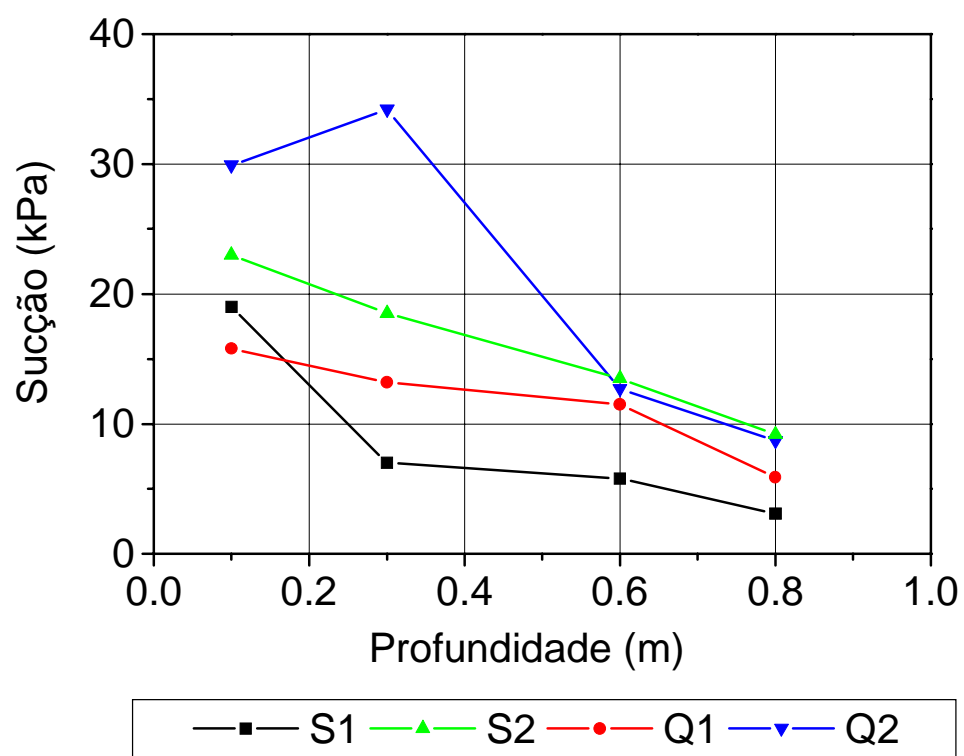

FIGURA 5.12 - Variação da sucção matricial com a profundidade nas provas de carga não inundadas. Técnica de TDR

\section{Ensaio de frente de umedecimento}

Foi realizado um ensaio de frente de umedecimento com o emprego da técnica de TDR, com a finalidade de estimar a profundidade atingida pela água ao final de 24 horas de inundação da cava. O ensaio foi conduzido na cava da prova de carga MS3, sendo tomadas leituras de $\varepsilon$ em tempos predeterminados desde o início da inundação até terem sido completadas as 24 horas. Os valores de $\varepsilon$ foram convertidos em valores de umidade volumétrica através da expressão 5.1. O resultado desse ensaio é mostrado na Figura 5.12, a qual exibe a variação da umidade volumétrica com o tempo em profundidades de 0,1 a $0,8 \mathrm{~m}$. 


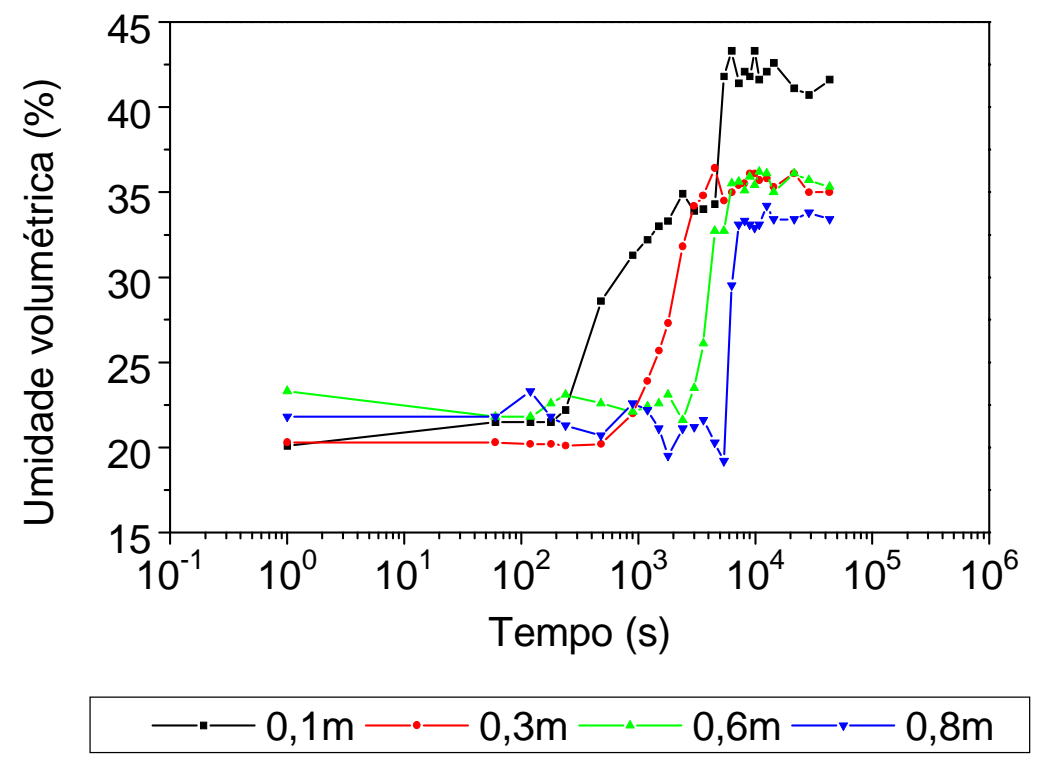

FIGURA 5.13 - Frente de umedecimento em diversas profundidades. Técnica de TDR

\subsection{2 - Tensiometria}

A Figura 5.14 mostra a variação da sucção matricial com a profundidade, observada com o auxílio dos tensiômetros instalados no fundo da cava nas provas de carga não inundadas.

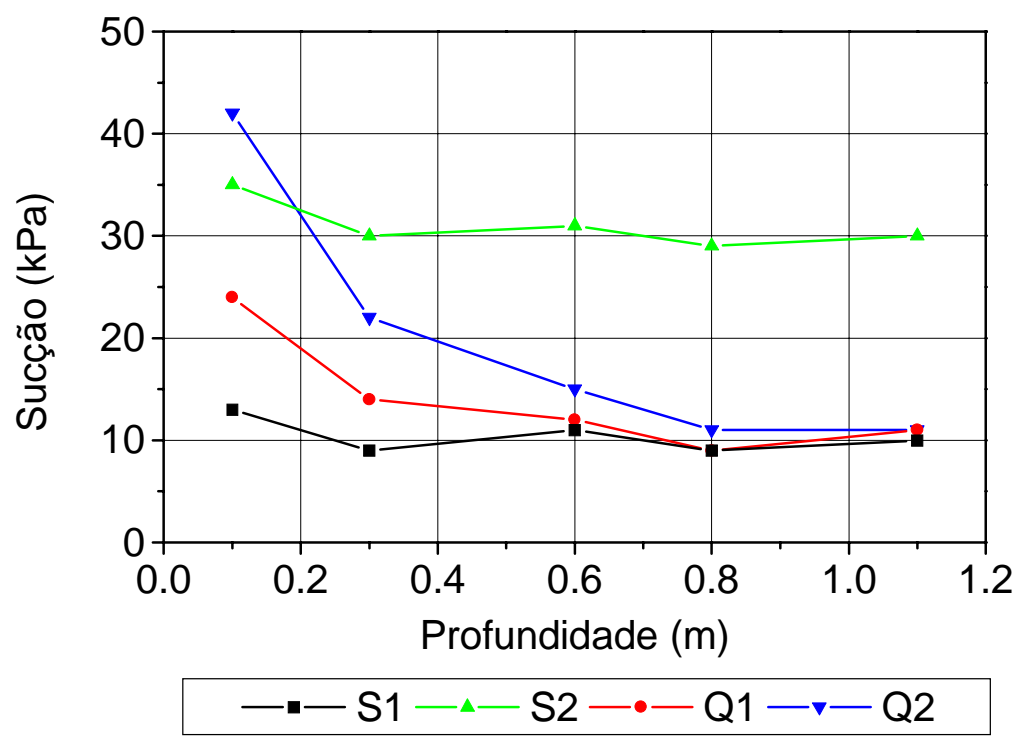

FIGURA 5.14 - Variação da sucção matricial com a profundidade nas provas de carga não inundadas, verificada pelos tensiômetros 


\subsection{3 - Retirada de amostras deformadas}

Os resultados de variação do teor de umidade com a profundidade obtidos através da retirada de amostras deformadas nas cavas dos ensaios não inundados são exibidos na Figura 5.15. Uma vez que se obteve originalmente o teor de umidade gravimétrica, para a se chegar à umidade volumétrica, admitiu-se um valor constante para $\gamma_{\mathrm{d}}$, igual a $13,6 \mathrm{kN} / \mathrm{m}^{3}$.



FIGURA 5.15 - Variação da umidade volumétrica com a profundidade nas provas de carga não inundadas. Coleta de amostras deformadas 


\section{6 - ANÁLISE DOS RESULTADOS}

\section{1 - PROVAS DE CARGA}

\subsection{1 - Tempo de inundação e grau de saturação do solo nos ensaios inundados}

Através do resultado do ensaio de frente de umedecimento realizado com o emprego da técnica de TDR (Figura 5.13), estimou-se o tempo necessário para a água atingir as profundidades de 0,1 a $0,8 \mathrm{~m}$ após o início da inundação, como mostra a Tabela 6.1. O tempo necessário para a estabilização do teor de umidade também é exibido na mesma tabela. Como a frente de umedecimento alcança a última profundidade de medida em aproximadamente 1 h e 30 min e a estabilização ocorre em $2 \mathrm{~h}$, presume-se que a inundação da cava por um período de $24 \mathrm{~h}$ tenha sido suficiente para o solo abaixo da placa ter apresentado o máximo grau de saturação de campo durante os ensaios.

TABELA 6.1 - Tempo de chegada da frente e de estabilização do teor de umidade

\begin{tabular}{c|c|c}
\hline \multirow{2}{*}{$\begin{array}{c}\text { Profundidade } \\
(\mathrm{m})\end{array}$} & Chegada & Tempo (s) \\
\cline { 2 - 3 } & 240 & 5400 \\
0,1 & 480 & 4500 \\
0,6 & 2400 & 6300 \\
0,8 & 5400 & 7200 \\
\hline
\end{tabular}

Através da Tabela 5.1, observa-se que os valores mínimo e máximo de teor de umidade volumétrica obtidos nas provas de carga inundadas foram, respectivamente, iguais a 30,1\% no ensaio Q1-r para as profundidades de 0,3 e $0,6 \mathrm{~m}$ e $43 \%$ no 
ensaio QS2, verificado na profundidade de $0,1 \mathrm{~m}$. Isso significa que o grau de saturação do solo nos ensaios inundados variou entre 61 e $87 \%$.

\subsection{2 - Valores de sucção representativos das provas de carga}

Para as análises subsequentes, é necessário associar a cada prova de carga um valor único para a sucção do solo abaixo da placa no momento do ensaio. Dessa forma, a sucção representativa de cada ensaio foi convencionada como a média dos resultados registrados pelos tensiômetros instalados dentro da cava, até uma profundidade igual ao diâmetro da placa. A Tabela 6.2 exibe a sucção correspondente a cada ensaio. Para as provas de carga com inundação, a sucção foi considerada igual a zero.

Apesar de ter sido utilizada a média dos valores para a obtenção de um nível de sucção para cada prova de carga, a influência da sucção do solo não deve ser a mesma ao longo da profundidade assumida. Contudo, embora a sucção em regiões mais próximas da placa deva preponderar na resposta do sistema, uma quantificação dessa influência seria bastante complexa. Por outro lado, há ainda o problema do desconhecimento do campo de tensões gerado abaixo da placa, dificultando ainda mais tal análise. Profundidades entre uma e duas vezes a menor largura do elemento de fundação $B$ são as mais comumente adotadas.

TABELA 6.2 - Sucção adotada em cada prova de carga

\begin{tabular}{c|cccc|c}
\hline \multirow{3}{*}{ Prova de carga } & \multicolumn{4}{|c|}{ Sucção medida $(\mathrm{kPa})$} & \multirow{2}{*}{ Sucção adotada $(\mathrm{kPa})$} \\
\cline { 2 - 5 } & 0,1 & 0,3 & 0,6 & 0,8 & \\
\hline Inundadas & - & - & - & - & 0 \\
S1 & 13 & 9 & 11 & 9 & 10 \\
S2 & 35 & 30 & 31 & 29 & 30 \\
Q1 & 24 & 14 & 12 & 9 & 15 \\
Q2 & 42 & 22 & 15 & 11 & 22 \\
\hline
\end{tabular}




\subsection{3 - Tensão de ruptura e tensão de colapso}

As curvas tensão-recalque, apresentadas no capítulo 5 exibem, na fase de deformações plásticas, uma relação praticamente linear entre o recalque e a correspondente carga aplicada. Isto mostra que o solo manifesta um comportamento de encruamento a partir de um determinado nível, no qual qualquer acréscimo de tensão acarreta um aumento de sua rigidez. Tal conduta pode da mesma maneira ser comprovada para recalques além dos usuais $50 \mathrm{~mm}$, através das provas de carga QS2 e $\mathrm{S} 1$, as quais foram conduzidas até aproximadamente $70 \mathrm{~mm}$. Observa-se ainda que o fenômeno ocorreu igualmente em todos os níveis de sucção medidos, inclusive com inundação do solo.

Em virtude da forma apresentada por essas curvas, constata-se a inexistência de ruptura física do solo e, por isso, se torna inadequada a aplicação de critérios matemáticos para extrapolação da curva e obtenção da tensão de ruptura $\sigma_{r}$, inclusive o destacado método de VAN DER VEEN (1953). Dessa forma, passou-se a utilizar um critério de ruptura convencional, ou seja, um critério no qual a tensão de ruptura corresponde a um nível de deslocamento escolhido. Foi então convencionado o recalque de $25 \mathrm{~mm}$.

Alguns códigos de obras e normas estipulam como critério de ruptura que a tensão admissível seja obtida a partir da divisão da tensão correspondente ao recalque de $25 \mathrm{~mm}$ por um determinado coeficiente de segurança, em geral igual a 2 (item 2.1.3, capítulo 2). O critério de ruptura convencional da NBR 6122/96, para provas de carga em estacas, também fornece um valor de recalque de cerca de 25 $\mathrm{mm}$, se aplicado a uma placa de $0,8 \mathrm{~m}$ de diâmetro.

$\mathrm{Na}$ terminologia adotada, a tensão de ruptura dos ensaios com inundação prévia será referida como tensão de colapso $\sigma_{c}$. A Tabela 6.3 apresenta a tensão de ruptura e a de colapso obtidas nos ensaios realizados. 
TABELA 6.3 - Tensões de ruptura e de colapso nas provas de carga

\begin{tabular}{c|c|c|c|c}
\hline Ensaio & Designação & Sucção $(\mathrm{kPa})$ & $\sigma_{\mathrm{r}}(\mathrm{kPa})$ & $\sigma_{\mathrm{c}}(\mathrm{kPa})$ \\
\hline 1 & SS1 & 0 & - & 69,2 \\
4 & SS2 & 0 & - & 47,1 \\
11 & SS3 & 0 & - & 60,2 \\
2 & QS1 & 0 & - & 63,9 \\
5 & QS2 & 0 & - & 66,4 \\
3 & MS1 & 0 & - & 65,9 \\
6 & MS2 & 0 & - & 73,1 \\
13 & MS3 & 0 & - & 55,5 \\
9 & S1 & 10 & 107,6 & - \\
12 & S2 & 30 & 146,0 & - \\
7 & Q1 & 15 & 97,2 & - \\
14 & Q2 & 22 & 121,2 & - \\
\hline
\end{tabular}

\subsection{4 - Influência da sucção na resposta do sistema}

A Figura 6.1 apresenta as curvas dos ensaios S1 e S2, juntamente com a curva média dos ensaios SS1, SS2 e SS3, com o objetivo de observar a resposta do sistema solo-placa em virtude da variação da sucção matricial. O mesmo se faz na Figura 6.2, com respeito aos ensaios QML, na qual se comparam as curvas de QS2, Q1 e Q2.

Em cada figura, considerando as duas curvas correspondentes a ensaios com sucção diferente de zero, observa-se que o deslocamento apresentado em cada nível de tensão é tão menor quanto maior a sucção medida na prova de carga. Em outras palavras, o solo sofre um aumento de rigidez provocado pelo crescimento da sucção. Isto denota a forte influência exercida pela sucção matricial na capacidade de carga do sistema solo-placa.

Através das Figuras 6.1 e 6.2, pode-se ainda observar o comportamento do sistema com a variação da sucção no que diz respeito ao colapso do solo. Para uma determinada tensão, comparando a curva relativa ao caso de inundação (sucção zero) com as demais, observa-se que quanto maior a sucção apresentada no ensaio não inundado, maior é a magnitude do colapso do solo. 


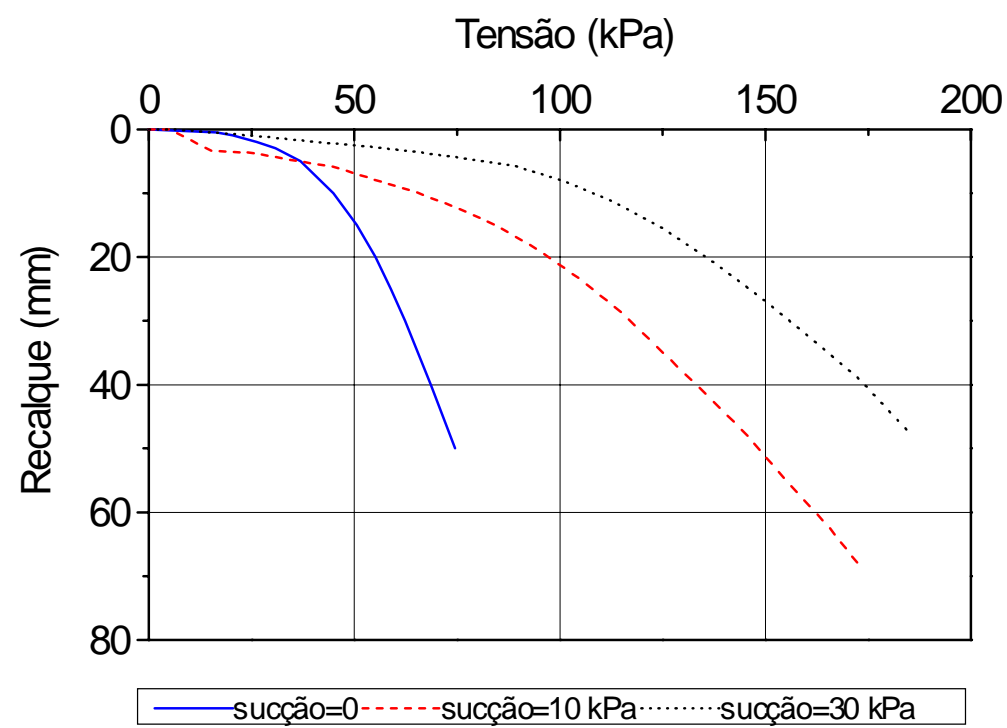

FIGURA 6.1 - Curvas tensão-recalque dos ensaios SML realizados em diferentes níveis de sucção

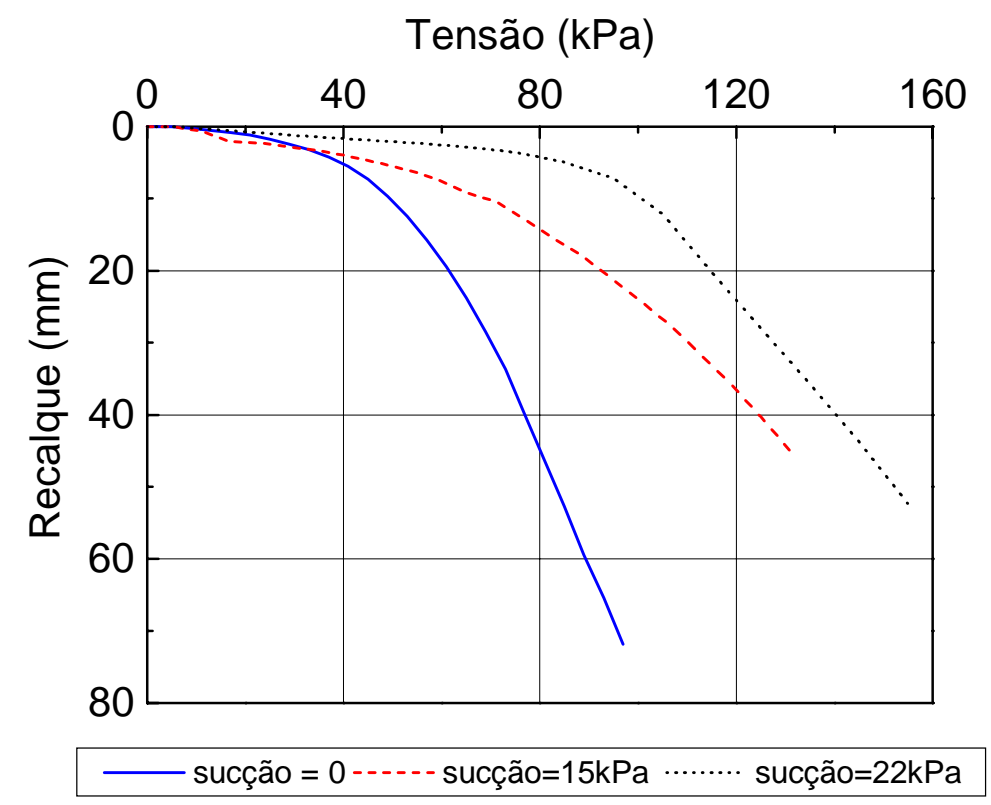

FIGURA 6.2 - Curvas tensão-recalque dos ensaios QML realizados em diferentes níveis de sucção 
A Figura 6.3 ilustra o aumento de $\sigma_{r}$ e $\sigma_{c}$ com o crescimento da sucção matricial, fazendo distinção entre os ensaios SML e QML $\left(\sigma_{\mathrm{c}}\right.$ representa a média dos valores obtidos). A mesma figura mostra ainda um ajuste de uma reta aos pontos obtidos, permitindo estimativas da capacidade de carga do solo para uma determinada sucção (expressão 6.1).

$\sigma_{\mathrm{r}}=67,26+2,77\left(\mathrm{u}_{\mathrm{a}}-\mathrm{u}_{\mathrm{w}}\right)$

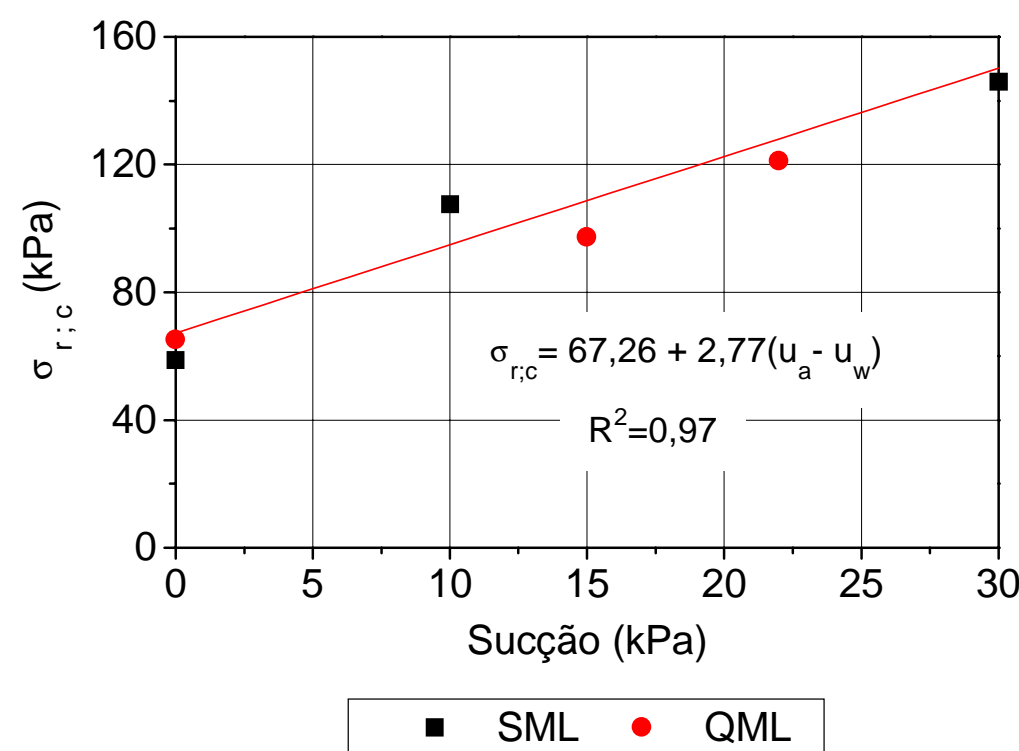

FIGURA 6.3 - Variação de $\sigma_{\mathrm{r}}$ e $\sigma_{\mathrm{c}}$ dos ensaios SML e QML com a sucção matricial

$\mathrm{Na}$ realidade, a tensão de ruptura não deve obedecer a uma lei linear de crescimento, mas sim tender à estabilização com o aumento da sucção. Pode-se dizer que a superfície formada deve se aproximar da superfície de escoamento LC, proposta por ALONSO et al. (1987). Ao se atingir esta superfície, provocam-se deformações plásticas no solo, seja por diminuição no valor da sucção, seja por acréscimos de carga.

Destaca-se ainda que a equação 6.1 não deve ser utilizada como meio para se estimar um valor de projeto para a tensão admissível, a partir de um determinado nível de sucção medido in situ. Uma vez que a sucção é um parâmetro de variação 
sazonal no maciço, não se pode assegurar a permanência de um determinado valor ao longo do tempo.

Todavia, resultados discrepantes entre provas de carga em placa executadas em locais próximos não são difíceis de ser obtidos. Geralmente, tal divergência é atribuída à variabilidade do solo e/ou a problemas de cunho executivo, não sendo levada em consideração a possibilidade da sucção matricial ser o parâmetro de maior influência (STEENFELT, 1987). Assim, uma equação desse gênero torna-se útil quando considerada como uma ferramenta auxiliar no controle da qualidade da prova de carga.

\subsection{5 - Redução da tensão de ruptura devido ao colapso}

A Tabela 6.4 mostra a diminuição da tensão de ruptura em relação à tensão de colapso, para os diferentes níveis de sucção medidos nos ensaios SML e QML. Podese notar que o decréscimo torna-se mais expressivo para maiores níveis de sucção.

TABELA 6.4 - Redução da tensão de ruptura em relação à tensão de colapso

\begin{tabular}{ccc}
\hline Ensaio & Sucção $(\mathrm{kPa})$ & Redução de $\sigma_{\mathrm{r}}(\%)$ \\
\hline S1 & 10 & 45 \\
S2 & 30 & 60 \\
Q1 & 15 & 33 \\
Q2 & 22 & 46 \\
\hline
\end{tabular}

\subsection{6 - Realização de ensaios mistos}

A proposição inicial da realização dos ensaios mistos era comparar seus resultados com os dos ensaios SML e QML para verificar a adequação do emprego dessas provas de carga ao solo estudado. Logicamente, tais comparações envolveriam análises com o solo apresentando diferentes níveis de sucção. Contudo, como será relatado em detalhe mais adiante, um comportamento particular nas duas primeiras provas de carga mista (inundadas) foi observado. Esse fato provocou uma 
modificação nos planos iniciais, de modo que se optou pela realização de um terceiro ensaio misto inundado em lugar da execução de ensaios mistos não inundados.

O comportamento particular observado em MS1 e MS2 ocorreu na transição do tipo de ensaio. Nas Figuras 6 e 7 do Anexo A, observa-se que a magnitude dos recalques é praticamente desprezível no primeiro estágio de carregamentos QML, causando uma visível descontinuidade entre as fases lenta e rápida. Em outras palavras, com a mudança do tipo de ensaio, ocorre um enrijecimento do solo de tal sorte a não permitir deformações no estágio além da casa do centésimo de milímetro. A partir do segundo estágio da fase de carregamentos rápidos, a deformação volta a ocorrer em níveis plausíveis, tornando-se mais intensa a cada estágio.

Comportamento similar não parece ter sido observado por ALONSO (1997), em provas de carga mista em estacas do tipo hélice contínua, realizadas com incrementos de carga na fase rápida correspondendo a uma parcela dos incrementos na fase lenta. Em complementação, as curvas carga-recalque obtidas por esse autor não apresentam descontinuidade que permita distinguir a fase lenta da rápida. Já nos resultados apresentados por LOPES et al. (1998), que executaram prova de carga mista em uma sapata quadrada de lado igual a 1,20 m apoiada em solo residual da região de Viçosa-MG, pode-se notar uma distinção nítida entre a fase lenta e a rápida na curva carga-recalque. Assim como em ALONSO (1997) e no presente trabalho, o incremento de carga da fase rápida representa uma fração do incremento na fase lenta. Contudo, como os recalques iniciais não constam na curva carga-recalque, não se sabe se ocorreu um comportamento similar ao relatado, no estágio de transição do tipo de carregamento.

No presente trabalho, como as únicas mudanças realizadas durante a troca do tipo de carregamento foram a redução pela metade do incremento de carga e a limitação do desenvolvimento da deformação do solo no estágio por um tempo de 15 minutos, supôs-se que a causa do surgimento deste comportamento estivesse ligada a um desses dois fatores. No entanto, a hipótese da limitação dos recalques a 15 minutos foi logo descartada, pois como se observou nas demais provas de carga, esse 
período é suficiente para permitir a ocorrência de deformações em magnitudes consideráveis.

Assim, o propósito da execução da terceira prova de carga mista, MS3, foi o de dirimir esta dúvida. Para tanto, a mesma foi realizada com incrementos de carga iguais tanto na fase lenta quanto na rápida. Como pode ser observado na Figura 8 do Anexo A, o comportamento tal como citado anteriormente não se repetiu, provando então que a diminuição do incremento de carga na troca do tipo de carregamento foi o fator que veio a acarretar o comportamento do solo como anteriormente descrito.

A Figura 6.4 compara as curvas dos ensaios MS1, MS2 e MS3 com as dos demais ensaios inundados SML e QML. Pode-se observar que as curvas das provas de carga mista apresentam um comportamento semelhante ao das curvas dos outros dois tipos de ensaios, denotando ser viável sua aplicação ao solo estudado.

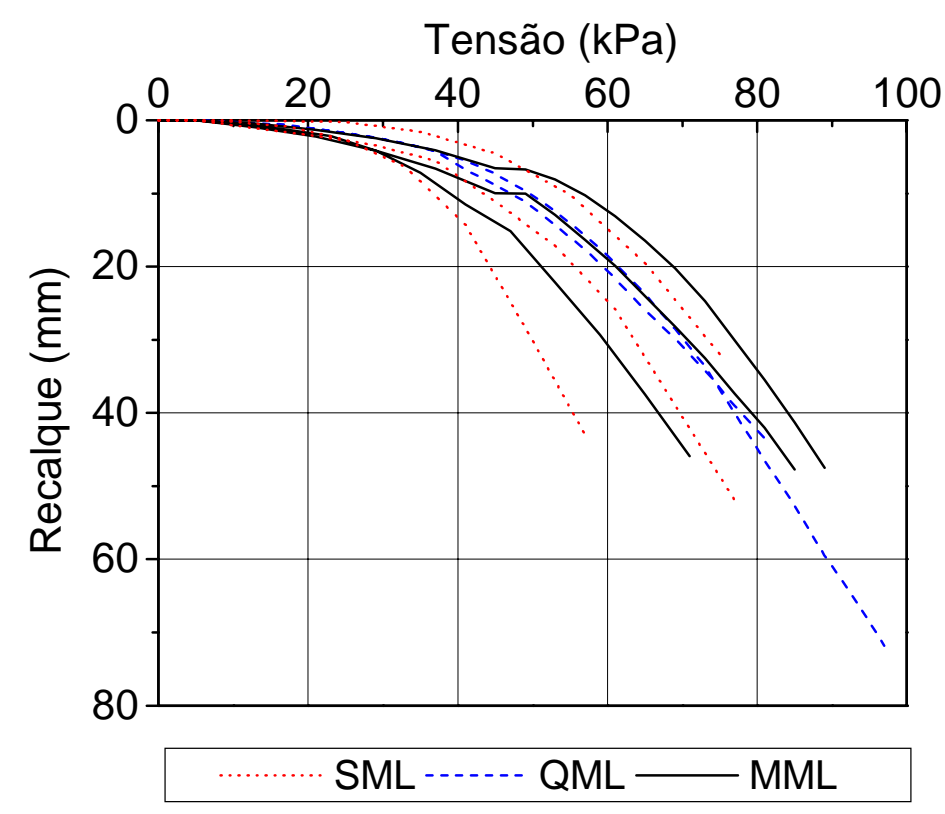

FIGURA 6.4 - Ensaios inundados SML, QML e MML 
A descontinuidade apresentada nos ensaios MS1 e MS2, apesar de constituir um aspecto interessante, em nada afeta os resultados em termos práticos. Tal fato poderia vir a ocorrer se os primeiros estágios subseqüentes ao estágio de transição para os carregamentos QML também apresentassem o mesmo comportamento particular mencionado ou se suas deformações fossem inferiores às observadas, tornando a descontinuidade mais acentuada. Neste caso, a parte da curva de estágios QML apresentaria uma forma semelhante à da curva $b$ da Figura 6.5, diferente daquela verificada nos ensaios realizados (representada pela curva $a$ ). Como consequiência, obter-se-ia uma tensão de ruptura contra a segurança $\left(\sigma_{r 2}\right)$, superior ao intervalo de valores apresentado pelos demais ensaios SML e QML.

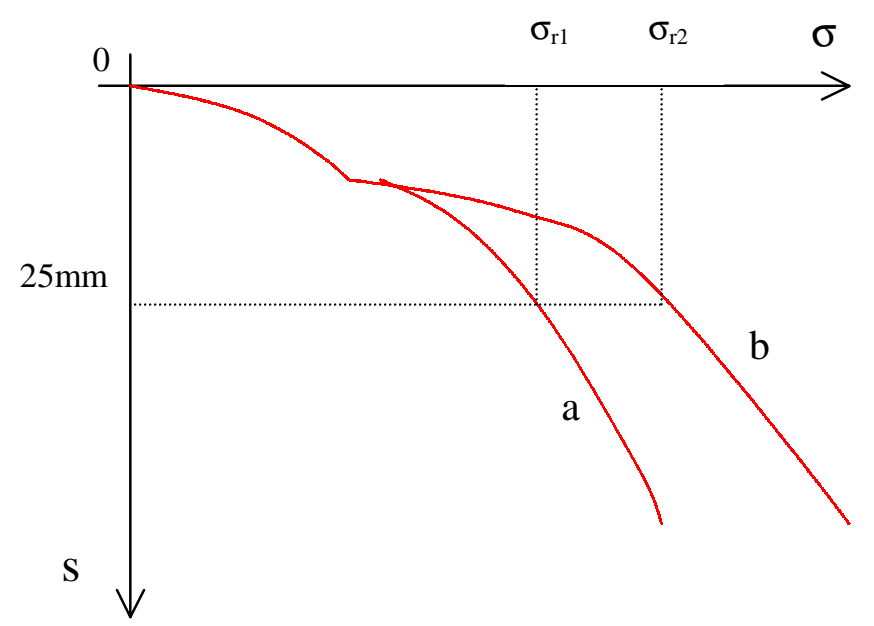

FIGURA 6.5 - Curva a: comportamento observado nos ensaios mistos.

Curva b: comportamento hipotético

As provas de carga mista revelam ainda algumas vantagens em relação aos outros tipos de ensaio. Com respeito aos ensaios SML, mostraram-se mais práticas, pois enquanto que o período médio de execução dos ensaios lentos inundados foi de 24 horas, os mistos consumiram um tempo médio de 14 horas. Por outro lado, diferentemente dos ensaios rápidos, possibilitaram que, até à provável tensão admissível do solo, os recalques em cada estágio se desenvolvessem assim como nos ensaios lentos. 


\subsection{7 - Ensaio SML versus ensaio QML}

Os objetivos iniciais deste trabalho previam a realização de uma série de provas de carga com inundação e outra com o solo apresentando a máxima sucção possível em campo. Em virtude das condições climáticas e do cronograma de ensaios do Campo Experimental, as provas de carga em placa não inundadas foram executadas em épocas distintas, havendo portanto variação da sucção no maciço. No entanto, este fato possibilitou uma forma mais interessante de análise dos dados, uma vez que se pôde observar nitidamente a influência da variação da sucção matricial nos resultados (Figuras 6.1 e 6.2).

Não obstante, comparações entre provas de carga lenta e rápida com respeito à influência do tipo de ensaio na resposta do sistema tornaram-se mais difíceis, justamente devido à diferença de sucção apresentada entre os ensaios. O único par possível de comparações diz respeito ao dos ensaios inundados. Pode-se ainda supor viável uma comparação entre $\mathrm{S} 1$ e Q1, devido à proximidade dos níveis de sucção medidos em ambas as provas de carga. A Figura 6.6 exibe a curva tensão-recalque média dos ensaios lentos inundados e a curva de QS2, juntamente com as curvas das provas de carga S1 e Q1.

Analisando a Figura 6.6, observa-se que a diferença entre as curvas dos ensaios lentos e rápidos é pequena. Isto parece indicar que o tipo de ensaio não é de grande relevância na resposta do sistema para o solo em estudo. Entretanto, um maior número de pares de ensaios rápidos e lentos com a mesma sucção é necessário em direção à análises mais apuradas.

Caso estudos posteriores venham a confirmar essa tendência, o ensaio rápido passaria a ser o mais recomendado devido à sua praticidade. O tempo médio de execução dos ensaios rápidos foi de sete horas e o dos lentos, de 24 horas para os inundados e de 72 horas para os não inundados. 


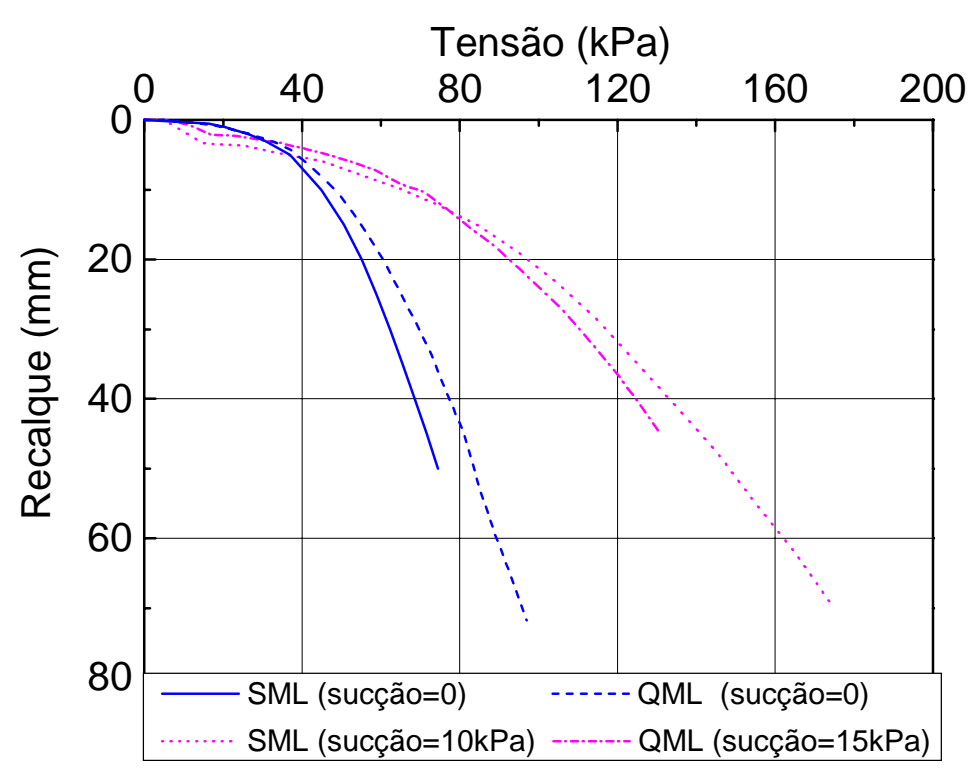

FIGURA 6.6 - Efeito do tipo de ensaio na resposta do sistema

\subsection{8 - Realização de reensaios}

As curvas dos reensaios apresentam uma forma praticamente bilinear, diferindo bastante da forma observada nos demais ensaios. As Figuras 6.7 e 6.8 comparam os resultados dos reensaios S1-r e Q1-r com os resultados dos ensaios inundados SML e QML, respectivamente.

Adotando para os reensaios o mesmo critério de ruptura utilizado nos ensaios, observa-se que, no caso de S1-r, a compactação do solo promovida pelo ensaio S1 foi suficiente para causar um aumento de 137 \% na tensão de colapso em comparação com a média dos ensaios SML inundados. Da mesma forma, $\sigma_{c}$ em Q1-r apresenta-se $49 \%$ superior à média de $\sigma_{c}$ dos ensaios QML inundados. 


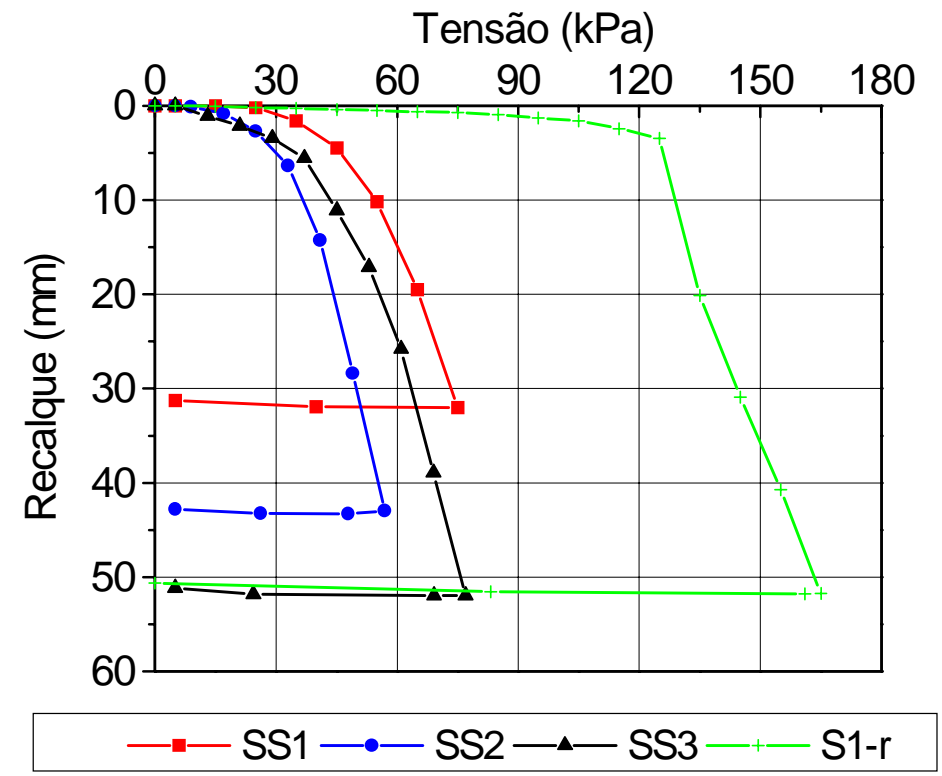

FIGURA 6.7 - Ensaios SML inundados e reensaio S1-r

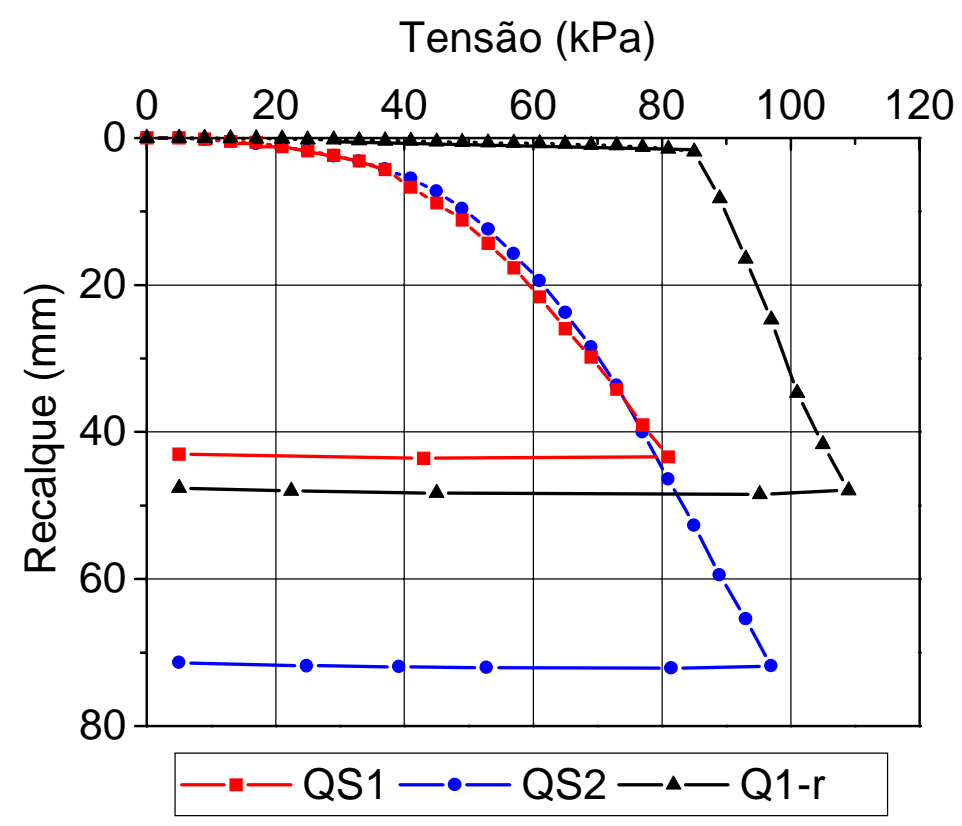

FIGURA 6.8 - Ensaios QML inundados e reensaio Q1-r 
A Tabela 6.5 exibe estimativas de algumas propriedades do solo antes da execução de S1-r e Q1-r, calculadas considerando a zona de influência dos carregamentos igual ao diâmetro da placa. A energia gasta nos ensaios S1 e Q1, responsável pela modificação das propriedades do solo, é quantificada em percentagem da energia de Proctor Normal. Destaca-se a baixa percentagem, já suficiente para causar um aumento de grande monta na capacidade de carga do solo, nos reensaios. Estes resultados enfatizam a eficácia do método de estabilização utilizado em fundação superficial que consiste na compactação do solo subjacente à sapata (SOUTO SILVEIRA \& SILVEIRA, 1958; SOUZA \& CINTRA, 1994).

TABELA 6.5 - Propriedades do solo antes do inicio de S1-r e Q1-r

\begin{tabular}{|c|c|c|}
\hline \multirow{2}{*}{$\begin{array}{l}\text { Propriedade } \\
\text { do solo }\end{array}$} & \multicolumn{2}{|c|}{ Ensaio } \\
\hline & S1-r & Q1-r \\
\hline$e_{f}$ & 0,82 & 0,88 \\
\hline Redução de $e_{0}(\%)$ & 17,5 & 12,5 \\
\hline$\%$ da energia de Proctor Normal & 1,0 & 0,5 \\
\hline $\mathrm{GC}(\%)$ & 80 & 77 \\
\hline Aumento em relação a $\mathrm{GC}_{\mathrm{nat}}(\%)$ & 9,6 & 5,5 \\
\hline
\end{tabular}

\subsection{9 - Comparações com ensaios de compressão confinada}

Neste item são realizadas comparações entre os resultados obtidos nas provas de carga em placa e resultados de ensaios de compressão confinada, com respeito à tensão de pré-adensamento e à tensão de ruptura. Os ensaios de laboratório foram conduzidos em corpos de prova de amostras coletadas no campo Experimental de Fundações da USP/São Carlos, às profundidades de 1 e $2 \mathrm{~m}$, fazendo parte do trabalho desenvolvido por MACHADO (1998).

Duas das trajetórias seguidas no espaço sucção-tensão durante a realização dos ensaios oedométricos encontram-se esquematizadas na Figura 6.9. A trajetória $\mathrm{AB}$ corresponde aos ensaios nos quais a sucção do corpo de prova era mantida constante, enquanto o mesmo sofria compressão. Na trajetória $\mathrm{ACD}$, possuindo uma determinada sucção inicial, o corpo de prova era inundado, passando a ter sucção 
praticamente igual a zero e em seguida eram aplicados os carregamentos. Trajetórias semelhantes foram utilizadas nas provas de carga em placa.

Contudo, deve-se fazer menção às diferenças existentes entre ambos os ensaios. O ensaio oedométrico representa um problema unidimensional, com condições de contorno conhecidas. Já a prova de carga em placa constitui um problema mais complexo, de ordem tridimensional, sendo necessário assumir várias hipóteses com relação às suas condições de contorno. Com respeito à sucção, apesar de trajetórias semelhantes às dos ensaios oedométricos terem sido seguidas durante as provas de carga em placa, no campo não há o mesmo controle sobre esse parâmetro como ocorre no laboratório. Ao contrário, a sucção no maciço durante a prova de carga está a mercê de diversos fatores externos que podem vir a mudá-la ao longo do ensaio.

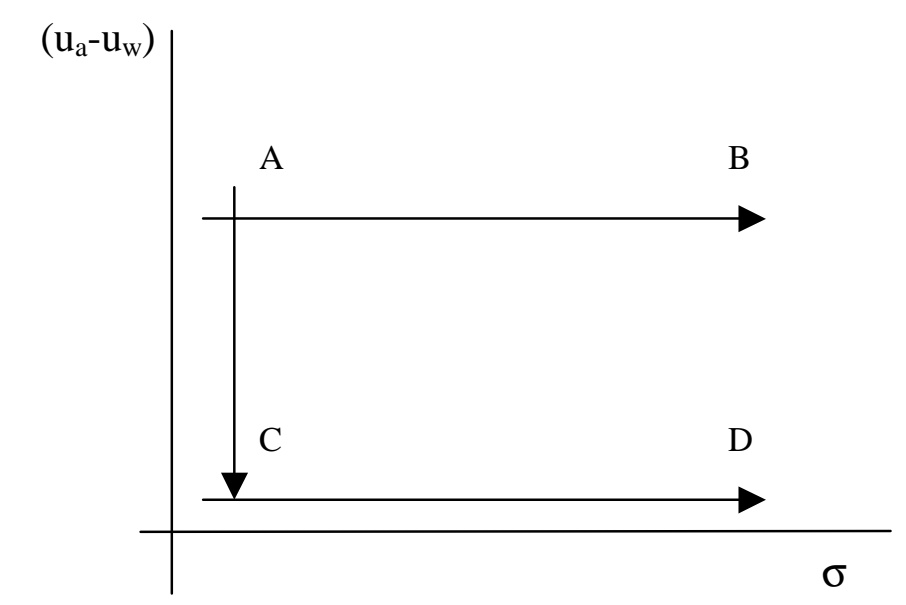

FIGURA 6.9 - Trajetórias seguidas durante ensaios oedométricos e provas de carga em placa

A Figura 6.10 exibe a variação da tensão de pré-adensamento $\sigma_{0}$ do solo em função da sucção, para as profundidades de 1 e $2 \mathrm{~m}$, juntamente com os respectivos ajustes propostos por MACHADO (1998). Para fins comparativos, na mesma figura 
também são plotados os pontos correspondentes à variação da tensão de ruptura $\sigma_{r} \mathrm{e}$ da tensão de colapso $\sigma_{c}$ com a sucção, obtidos nos ensaios de placa do tipo SML e QML.

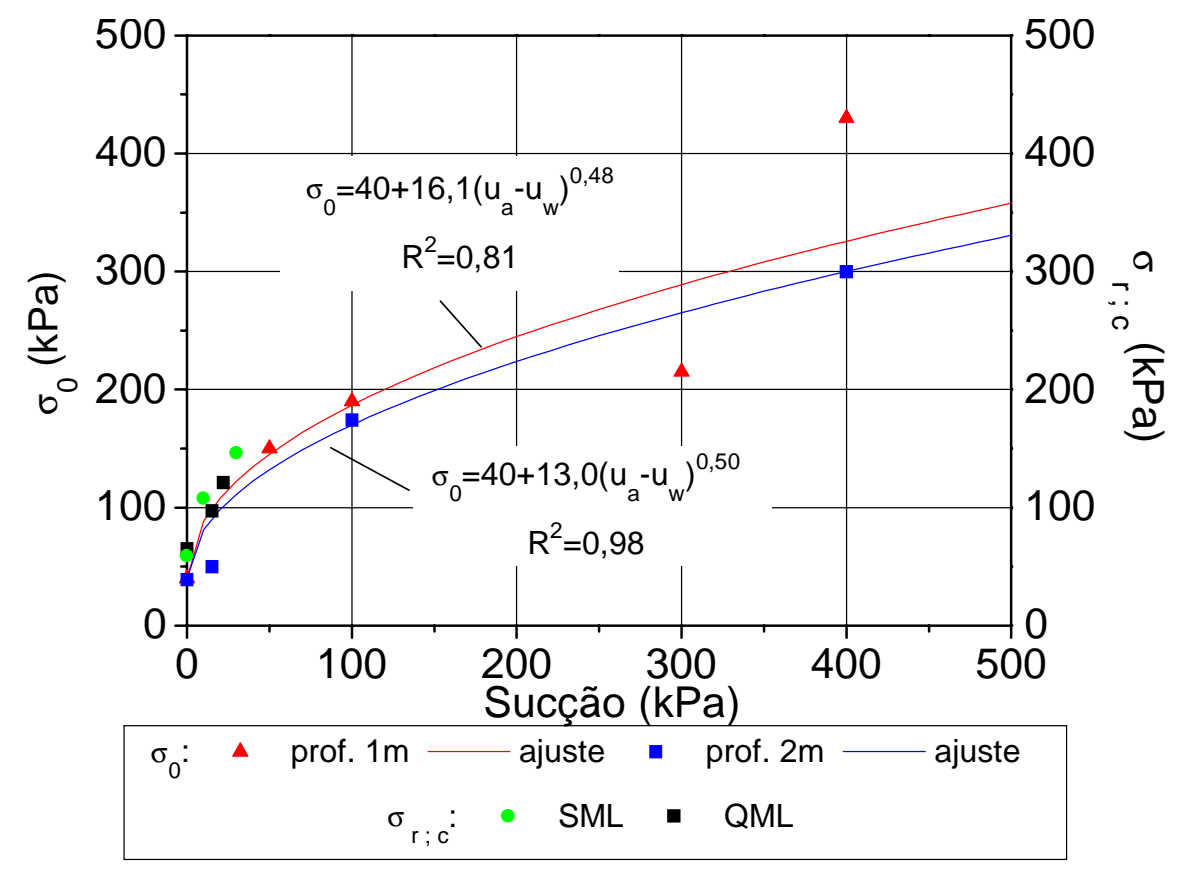

FIGURA 6.10 - Variação da tensão de pré-adensamento e da tensão de ruptura com a sucção

De modo a propiciar uma melhor visualização, a Figura 6.11 exibe no intervalo de sucções medidas em campo, os mesmos resultados da Figura 6.10 correspondentes aos ensaios SML e QML, juntamente com os ajustes para as profundidades de 1 e $2 \mathrm{~m}$. A Figura 6.11 revela que as tensões de ruptura e de colapso dos ensaios de placa relacionam-se com a sucção de forma bastante semelhante aos ajustes propostos para a variação da tensão de pré-adensamento com a sucção nos ensaios oedométricos. Tais ajustes parecem fornecer uma boa estimativa (a favor da segurança) de $\sigma_{r}$ e $\sigma_{c}$. 


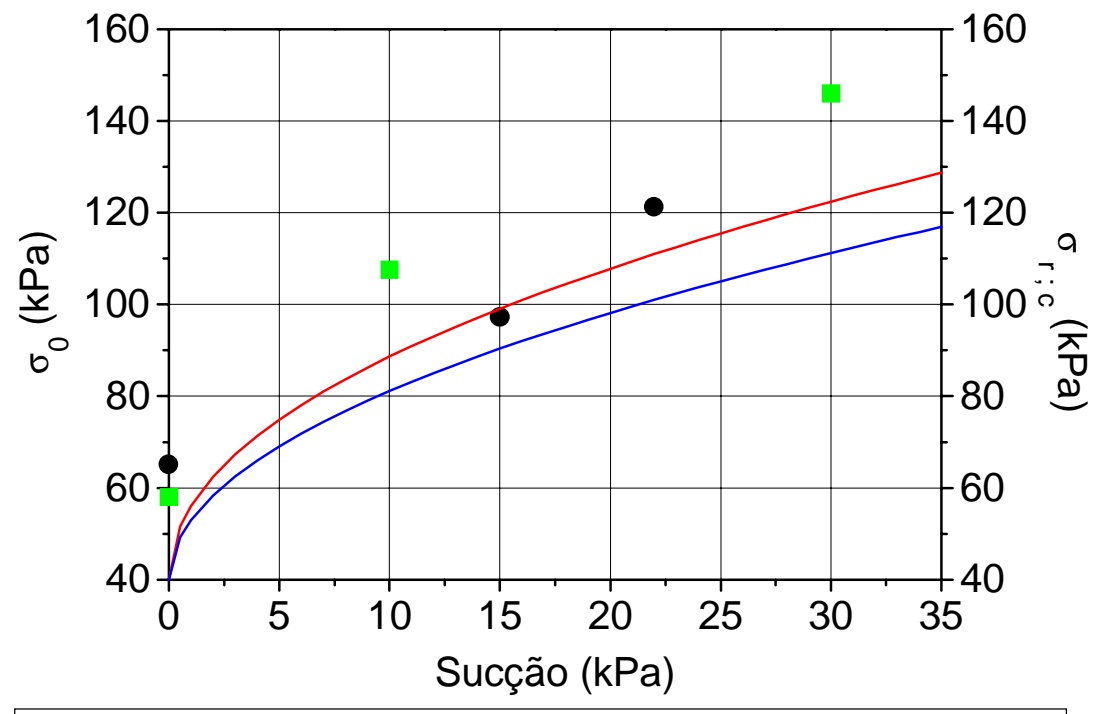

- SML • QML — ajuste $1 \mathrm{~m}$ — ajuste $2 \mathrm{~m}$

FIGURA 6.11 - Variação da tensão de ruptura das provas de carga SML e QML com a sucção e ajustes para a variação da tensão de pré-adensamento com a sucção

\section{2 - MODELAGEM NUMÉRICA DAS PROVAS DE CARGA EM PLACA}

Neste item é apresentada uma previsão classe C1 (LAMBE, 1973) das provas de carga em placa com inundação, através de simulações numéricas utilizando o programa computacional Sigma/w da Geo-Slope International. Empregando o Método dos Elementos Finitos, o aplicativo permite a execução de análises para diversos modelos matemáticos e condições de contorno do problema em questão.

As simulações numéricas foram realizadas a partir de parâmetros laboratoriais determinados por MACHADO (1998) em uma série de ensaios triaxiais convencionais $\mathrm{CID}_{\text {sat }}$ (consolidados isotropicamente drenados), realizados em amostras saturadas. Os corpos de prova foram obtidos a partir de amostras coletadas ao longo de um perfil no Campo Experimental às profundidades de 2m, 5m e 8m, de tal sorte a permitir a divisão da malha de elementos finitos em três camadas distintas. As duas primeiras representam a camada do Sedimento Cenozóico (0 a 6m) e a última, a camada do solo residual do Grupo Bauru (6 a 10m). A Figura 6.12 ilustra a malha, construída aproveitando-se a axissimetria do problema, juntamente com as condições de contorno adotadas. 


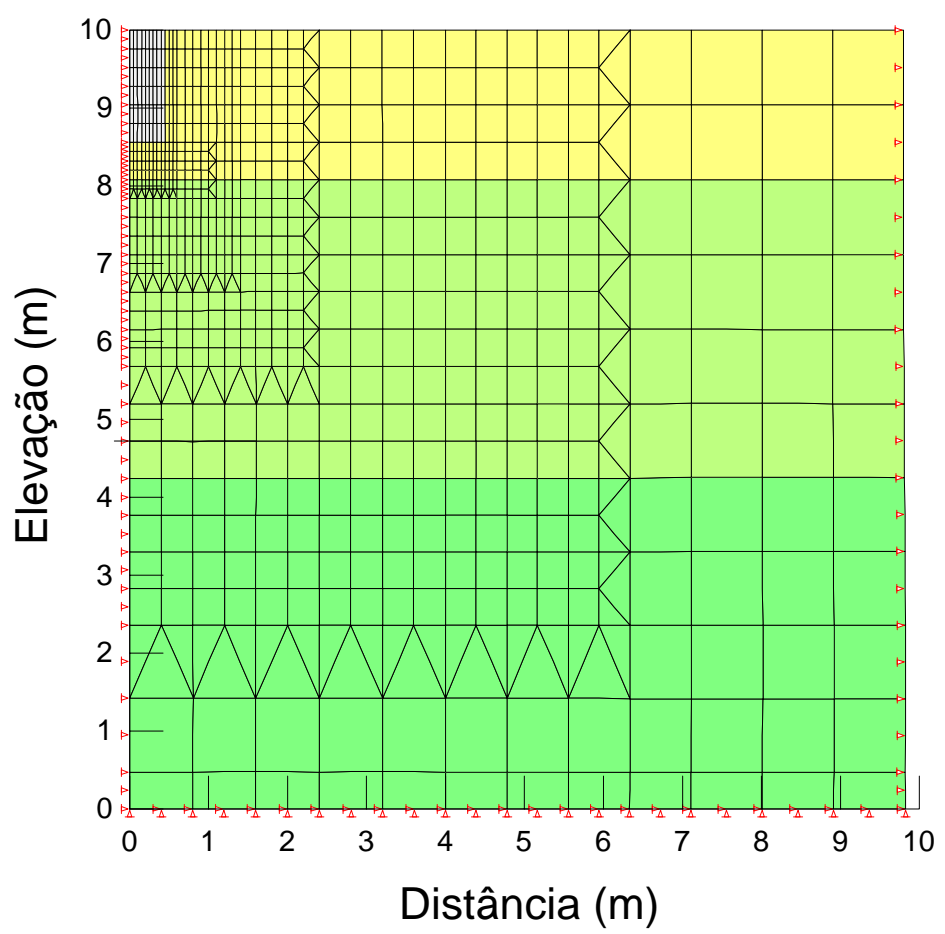

FIGURA 6.12 - Malha de elementos finitos

\subsection{1 - Estado inicial de tensões no solo}

A partir da malha da Figura 6.12, calculou-se o estado de tensões iniciais no solo decorrente do peso próprio. Numa segunda etapa, simulou-se o processo de escavação do solo, através da utilização de elementos de escavação entre as elevações 8,5 e 10,0 m, sendo novamente calculada a variação das tensões em virtude da remoção desses elementos. Para estas análises, o solo foi considerado um material homogêneo e elástico-linear, com $\mathrm{E}=10 \mathrm{MPa}$ e $v=0,32$. Os valores de peso específico dos estratos foram obtidos a partir da média aritmética dos pesos específicos natural dos corpos de prova utilizados na realização dos ensaios de laboratório (Tabela 6.6). Para todas as camadas, assumiu-se $\mathrm{K}_{0}=0,48$, obtido da expressão (6.2).

$\mathrm{K}_{0}=\frac{v}{1-v}$ 
As Figuras 6.13 e 6.14 apresentam a distribuição inicial das tensões verticais e cisalhantes do solo, respectivamente.

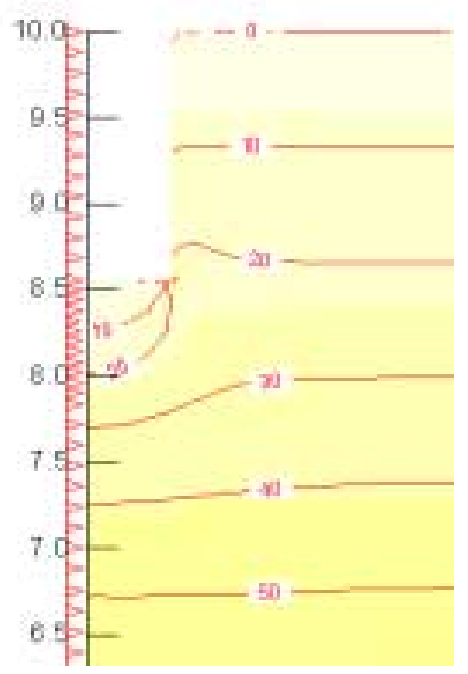

FIGURA 6.13 - Distribuição das tensões iniciais do solo em termos de tensões verticais (valores em $\mathrm{kPa}$ )

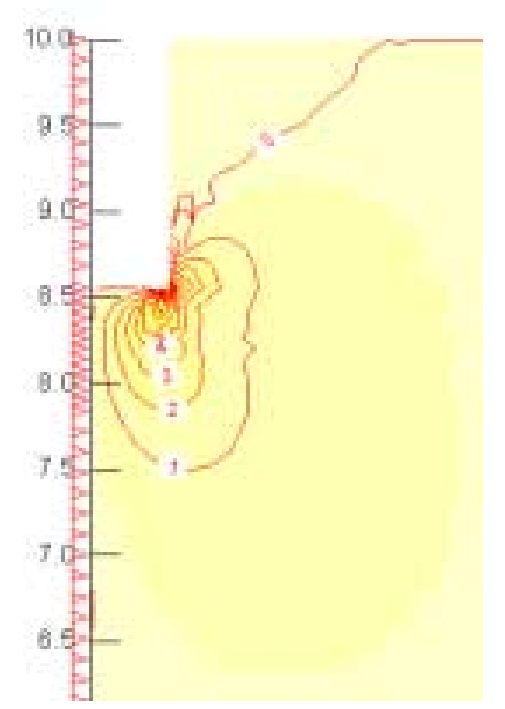

FIGURA 6.14 - Distribuição das tensões iniciais do solo em termos de tensões cisalhantes (valores em $\mathrm{kPa}$ ) 


\subsection{2 - Modelagem dos ensaios de placa}

Em seguida, procedeu-se à simulação numérica das provas de carga em placa. A princípio, foi utilizado o modelo elasto-plástico de Mohr-Coulomb, sendo verificada sua inadequação perante os resultados dos ensaios de campo. Dessa forma, passou-se a utilizar nas análises um modelo não-linear elástico (hiperbólico) (DUNCAN \& CHANG, 1970).

Deslocamentos ao solo de até $80 \mathrm{~mm}$ foram impostos de forma incremental ao longo de uma faixa de $0,8 \mathrm{~m}$, sendo calculada a tensão vertical média de reação. A opção de se impor deslocamentos representa a condição de estrutura de fundação rígida, uma vez que, desta forma, garantem-se deslocamentos iguais em cada momento ao longo de toda a extensão de aplicação. A Tabela 6.6 apresenta os valores adotados para os parâmetros do modelo utilizado, juntamente com os valores dos pesos específicos para cada estrato de solo.

TABELA 6.6 - Parâmetros utilizados no modelo adotado

\begin{tabular}{c|c|c|c|c|c|c|c|c|c|c}
\hline $\begin{array}{c}\mathrm{Ca} \\
\mathrm{ma} \\
\mathrm{da}\end{array}$ & $\begin{array}{c}\mathrm{c} \\
(\mathrm{kPa})\end{array}$ & $\begin{array}{c}\phi \\
(0)\end{array}$ & $\begin{array}{c}\mathrm{B} \\
(\mathrm{kPa})\end{array}$ & $\mathrm{K}_{\mathrm{b}}$ & $\mathrm{m}$ & $\mathrm{R}_{\mathrm{f}}$ & $\mathrm{K}$ & $\mathrm{n}$ & $\begin{array}{c}\mathrm{Pa} \\
(\mathrm{kPa})\end{array}$ & $\begin{array}{c}\gamma \\
\left(\frac{\mathrm{kN}}{\mathrm{m}^{3}}\right.\end{array}$ \\
\hline 1 & 6,0 & 29,0 & 1455,5 & 6,086 & 1,245 & 0,606 & 50,326 & 0,232 & 101,33 & 14,9 \\
2 & 10,5 & 31,1 & 1221,5 & 11,663 & 0,031 & 0,677 & 52,261 & $-0,146$ & 101,33 & 16,5 \\
3 & 28,4 & 26,4 & 1407,7 & 11,775 & 0,782 & 0,933 & 177,082 & $-0,274$ & 101,33 & 18,3 \\
\hline
\end{tabular}

Nota: $\mathrm{c}=$ coesão, $\phi=$ ângulo de atrito interno; $\mathrm{B}=$ módulo $B u l k ; \mathrm{K}_{\mathrm{b}}=$ número módulo; $\mathrm{m}=$ expoente do módulo Bulk; $\mathrm{R}_{\mathrm{f}}=$ taxa de ruptura; $\mathrm{K}=$ módulo do carregamento; $\mathrm{n}=$ expoente para o comportamento do carregamento; $\mathrm{Pa}=$ Pressão atmosférica; $\gamma=$ peso específico.

A Figura 6.15 mostra a zona de plastificação do solo para uma tensão vertical média de $97 \mathrm{kPa}$, correspondente a um recalque de $80 \mathrm{~mm}$. Os contornos de tensão vertical média no maciço para este estágio também são expostos na mesma figura. 


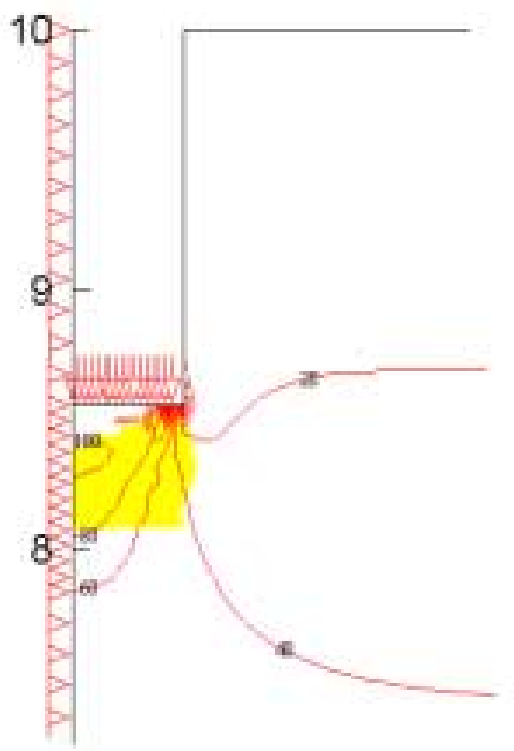

FIGURA 6.15 - Zona de plastificação do solo e contornos de tensões verticais para uma tensão correspondente a um recalque de $80 \mathrm{~mm}$

A Figura 6.16 ilustra a curva tensão-recalque proveniente da simulação numérica realizada, em conjunto com as curvas dos ensaios experimentais.

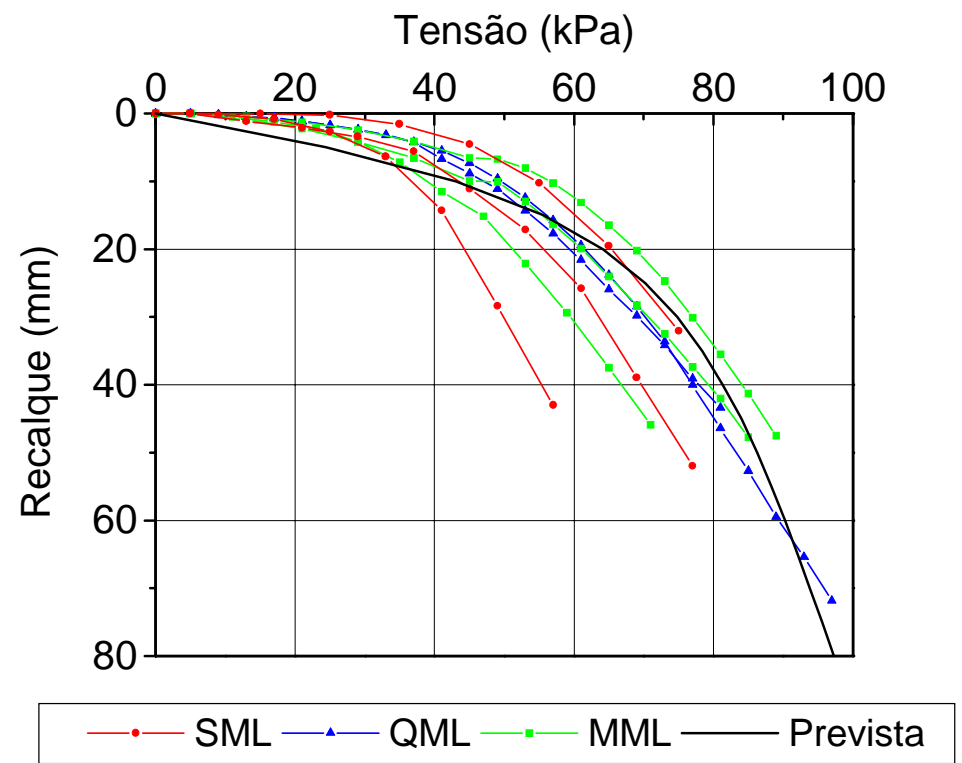

FIGURA 6.16 - Comparação das curvas carga-recalque dos ensaios de campo com a obtida através da simulação numérica 
A curva prevista apresenta-se em boa concordância com as curvas obtidas dos ensaios de campo. Apenas em seu trecho inicial, são observados recalques ligeiramente superiores àqueles verificados experimentalmente. Em termos de previsão da tensão de ruptura, há uma ótima aproximação entre a simulação numérica e os resultados obtidos: em comparação com a tensão de ruptura média dos ensaios de campo, o erro cometido na previsão foi inferior a $12 \%$.

\section{3 - REFLECTOMETRIA NO DOMÍNIO DO TEMPO (TDR)}

\subsection{1 - Comparações entre os métodos}

Este item tem por objetivo comparar os resultados de teor de umidade fornecidos pela técnica de TDR com os obtidos por retirada de amostras deformadas. Da mesma forma, comparam-se os resultados de sucção matricial gerados pela técnica de TDR e pelos tensiômetros. A variação do teor de umidade com a profundidade nas provas de carga não inundadas é exposta nas Figuras 6.17 a 6.20. As Figuras 6.21 a 6.24 mostram o comportamento da sucção com a profundidade através dos tensiômetros e da técnica de TDR.

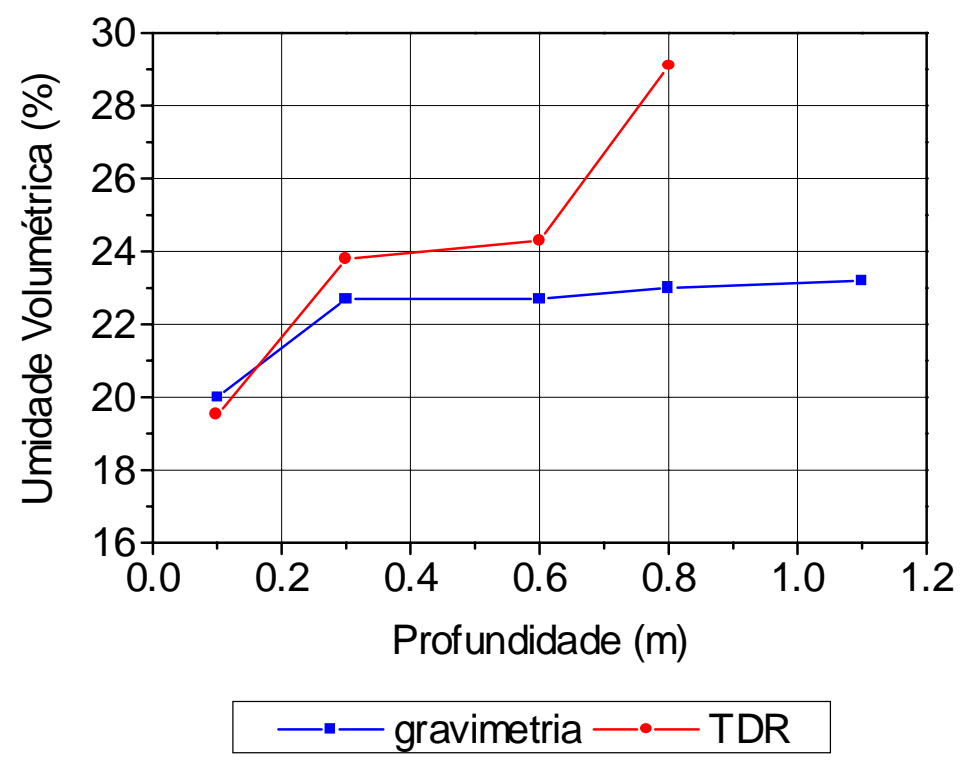

FIGURA 6.17 - Variação da umidade volumétrica com a profundidade por gravimetria e TDR. Ensaio S1 


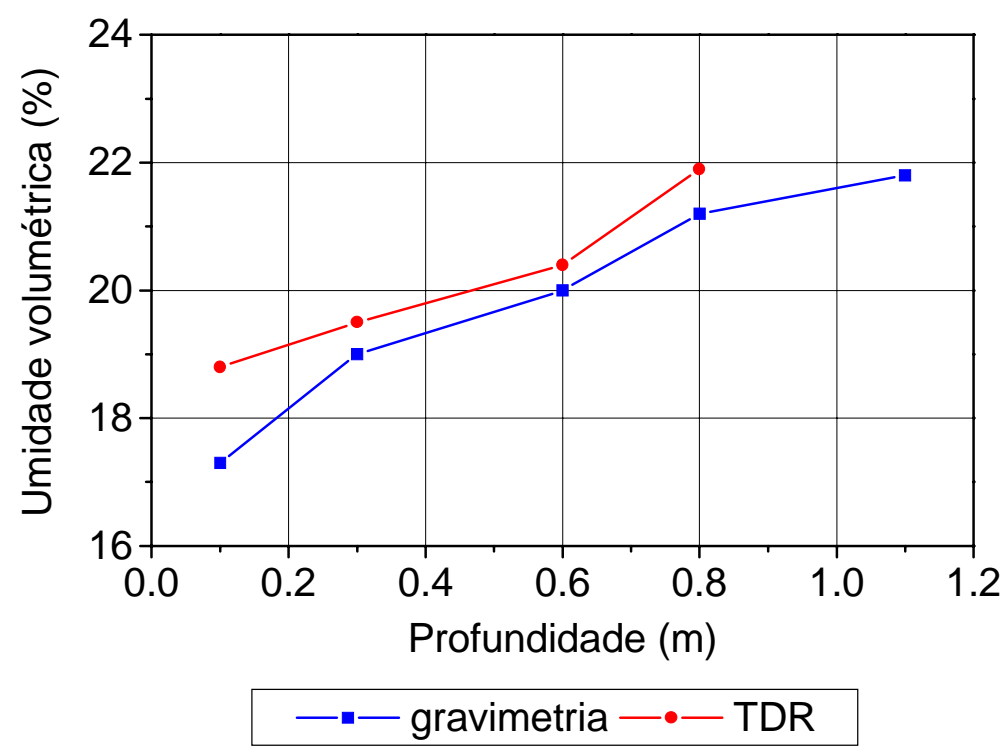

FIGURA 6.18 - Variação da umidade volumétrica com a profundidade por gravimetria e TDR. Ensaio S2

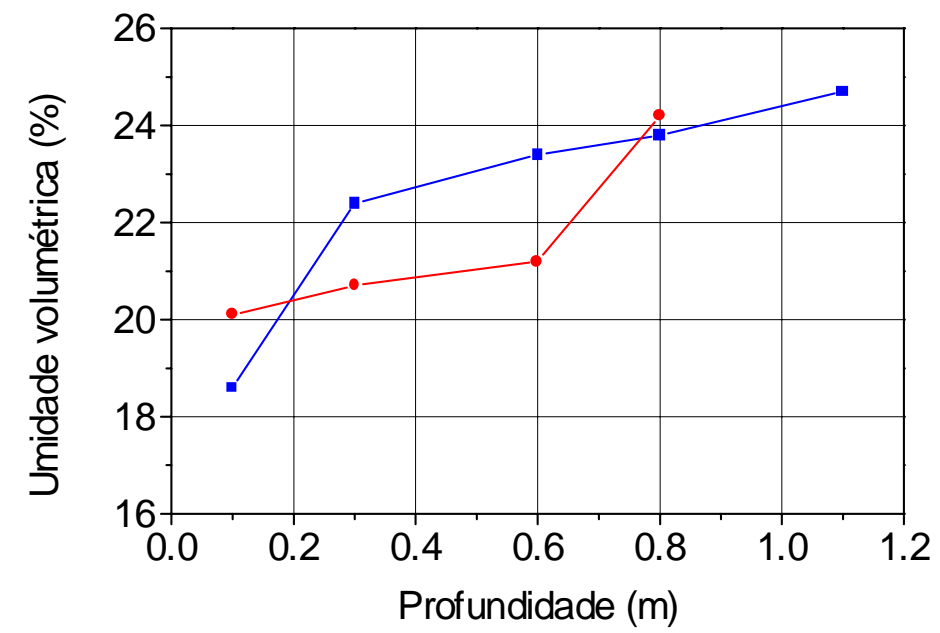

$\longrightarrow$ gravimetria $-\cdots$ TDR

FIGURA 6.19 - Variação da umidade volumétrica com a profundidade por gravimetria e TDR. Ensaio Q1 


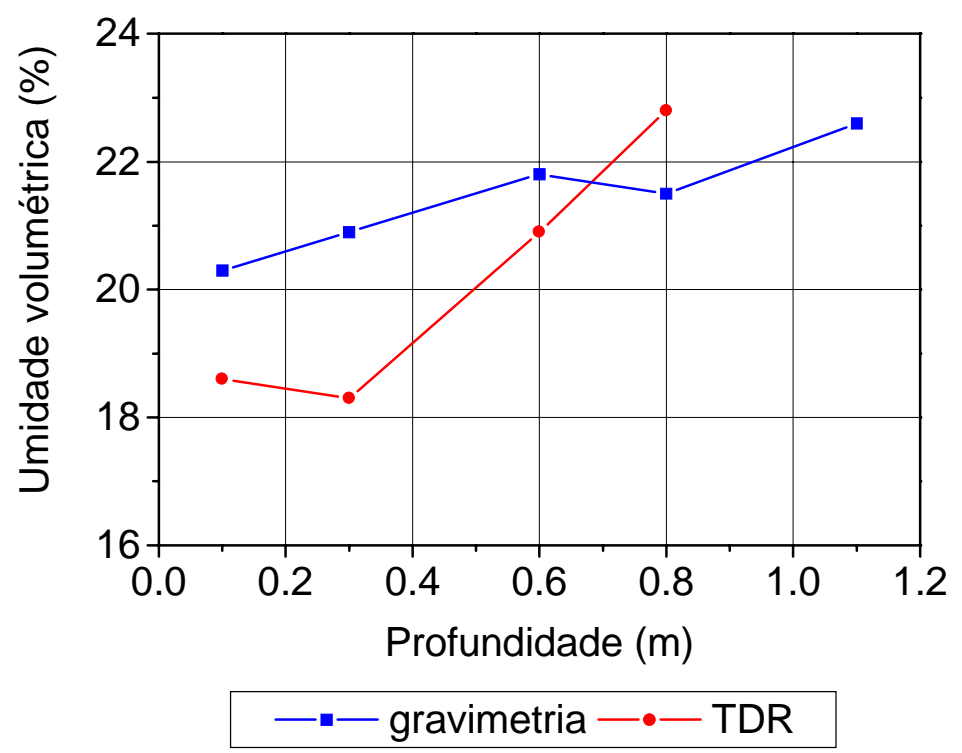

FIGURA 6.20 - Variação da umidade volumétrica com a profundidade por gravimetria e TDR. Ensaio Q2

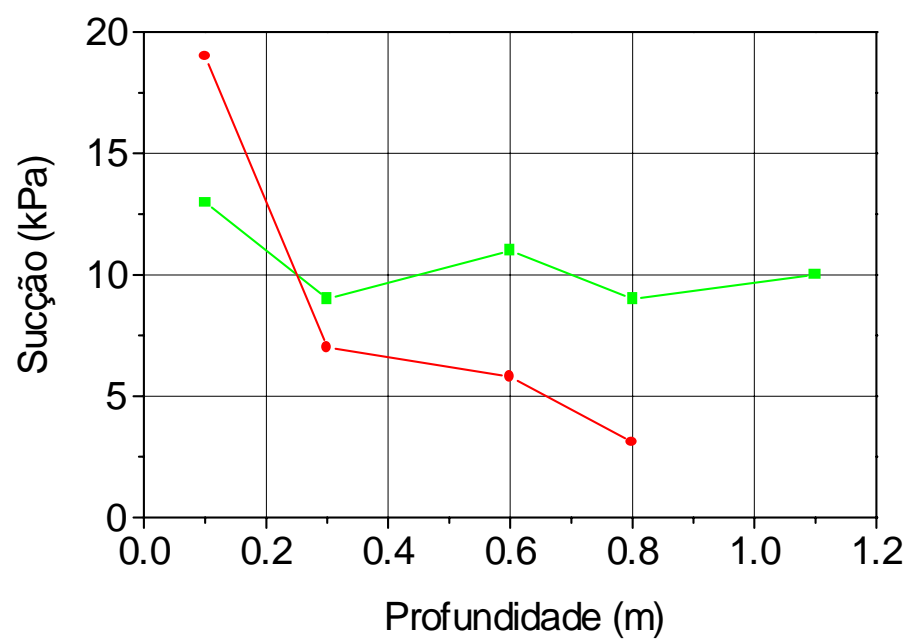

- - tensiometria $-\bullet-$ TDR

FIGURA 6.21 - Variação da sucção matricial com a profundidade por tensiometria e TDR. Ensaio S1 




- - tensiometria - - - TDR

FIGURA 6.22 - Variação da sucção matricial com a profundidade por tensiometria e TDR. Ensaio S2

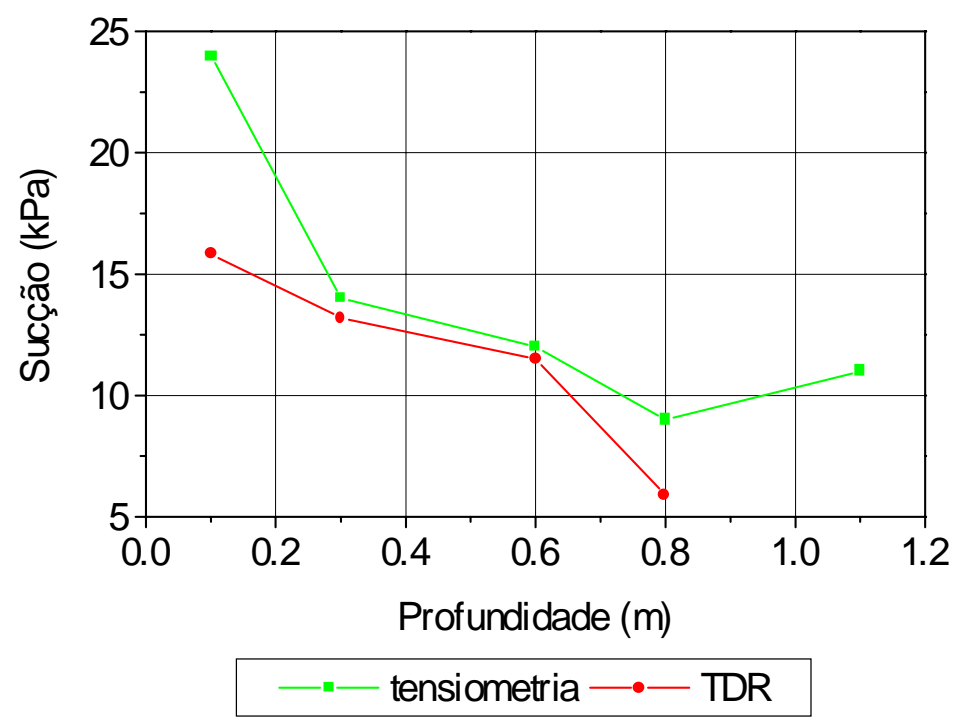

FIGURA 6.23 - Variação da sucção matricial com a profundidade por tensiometria e TDR. Ensaio Q1 


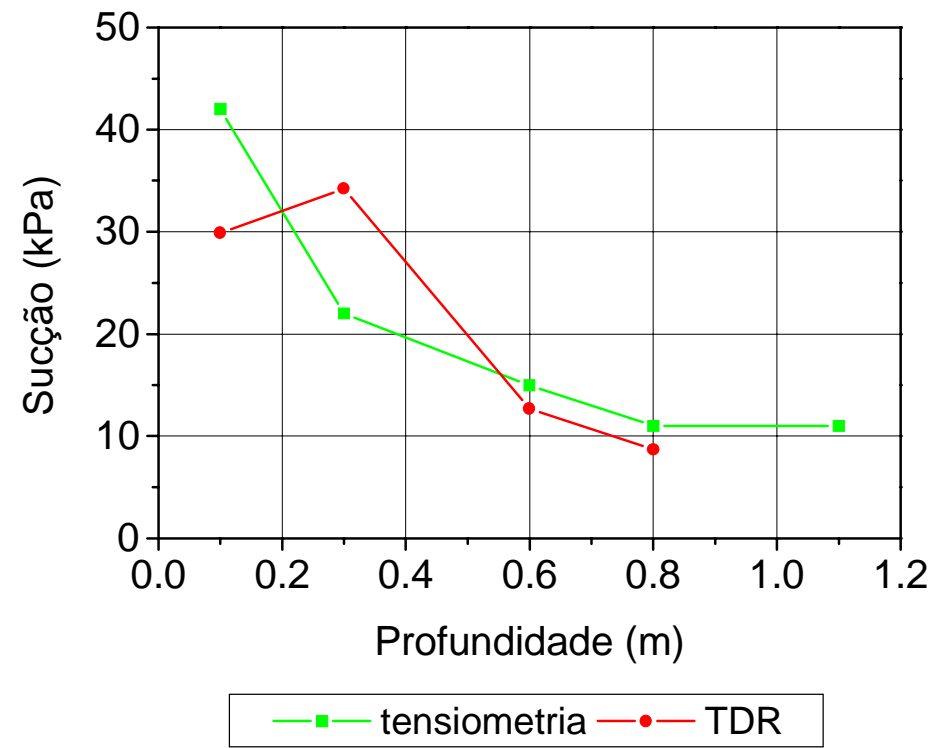

FIGURA 6.24 - Variação da sucção matricial com a profundidade por tensiometria e TDR. Ensaio Q2

As Figuras 6.17 a 6.20 mostram que os resultados da técnica de TDR apresentaram-se em boa concordância com os obtidos por pesagem de amostras, principalmente se se considera a influência da variabilidade do solo e das deficiências inerentes às técnicas. A única exceção diz respeito à profundidade de 0,8 $\mathrm{m}$ no ensaio S1, na qual se observou uma divergência maior. A Tabela 6.7 exibe o erro absoluto dos resultados obtidos pela técnica de TDR, em relação à gravimétrica.

TABELA 6.7 - Erro dos valores de teor de umidade obtidos através da técnica de TDR

\begin{tabular}{c|c|c|c}
\cline { 2 - 3 } & \multicolumn{2}{|c|}{ Umidade volumétrica (\%) } & Erro (\%) \\
\hline Prova de Carga & TDR & Gravimetria & 2,5 \\
S1 & 19,5 & 20,0 & 4,8 \\
& 23,8 & 22,7 & 7,0 \\
& 24,3 & 22,7 & 2,6 \\
\hline \multirow{3}{*}{ S2 } & 29,1 & 23,0 & 8,7 \\
& 18,8 & 17,3 & 2,6 \\
& 19,5 & 19,0 & 2,0 \\
Q1 & 20,4 & 20,0 & 3,3 \\
& 21,9 & 21,2 & 8,1 \\
& 20,1 & 18,6 & 7,6 \\
& 20,7 & 22,4 & 9,4 \\
& 21,2 & 23,4 & 1,7 \\
\hline \multirow{3}{*}{ Q2 } & 24,2 & 23,8 & 8,4 \\
& 18,6 & 20,3 & 12,4 \\
& 18,3 & 20,9 & 3,7 \\
& 21,0 & 21,8 & 6,0 \\
\hline
\end{tabular}


As Figuras 6.21 a 6.24 revelam ter havido uma menor concordância dos resultados obtidos pela técnica de TDR com os apresentados pelos tensiômetros. Análises para averiguar tal dispersão foram realizadas com o auxílio da curva característica da Figura 5.10. Valores de sucção obtidos das leituras de umidade volumétrica fornecidas pela retirada de amostras foram comparados aos obtidos através dos tensiômetros. A Tabela 6.8 apresenta os valores de sucção obtidos a partir das três técnicas utilizadas, mostrando o erro absoluto fornecido pela técnica de TDR em relação à de tensiometria (Erro 1-3). Da mesma forma, é apresentado o erro dos valores obtidos por gravimetria em relação ao resultados dos tensiômetros (Erro 2-3). Nota-se que os valores do Erro 2-3 muitas vezes são tão elevados quanto os do Erro 1-3 (ou até superiores), podendo indicar que as dispersões observadas entre os resultados fornecidos pela técnica de TDR e pelos tensiômetros não ocorreram unicamente por causa de possíveis deficiências da técnica de TDR.

Através da curva característica da Figura 5.10, pode-se observar que uma pequena variação do teor de umidade corresponde a uma variação de maior magnitude na sucção. Este comportamento tende a ser mais acentuado quanto mais baixo o teor de umidade. De fato, como se sabe, a sucção é um parâmetro bem mais difícil de ser correlacionado que o teor de umidade.

TABELA 6.8 - Erro dos valores de sucção obtidos pela técnica de TDR e de pesagem de amostras em relação aos fornecidos pelos tensiômetros

\begin{tabular}{c|c|c|c|c|c}
\cline { 2 - 4 } & \multicolumn{3}{c|}{ Sucção $(\mathrm{kPa})$} & \multicolumn{1}{c}{ Erro 2-3 } \\
Prova de & TDR & Gravimetria & Tensiômetria & $\begin{array}{c}\text { Erro 1-3 } \\
(\%)\end{array}$ & $\begin{array}{c}\text { Carga } \\
\text { S1 }\end{array}$ \\
\hline \multirow{3}{*}{ S1 } & 19,0 & 17,3 & $13)$ & 46,2 & 33,1 \\
& 7,0 & 8,1 & 9,0 & 22,2 & 10,0 \\
& 5,8 & 8,1 & 11,0 & 47,3 & 26,4 \\
& 3,1 & 7,5 & 9,0 & 65,6 & 16,7 \\
\hline \multirow{3}{*}{ S2 } & 23,0 & 49,2 & 35,0 & 34,3 & 40,6 \\
& 18,5 & 24,4 & 30,0 & 38,3 & 18,7 \\
& 13,5 & 17,3 & 31,0 & 56,5 & 44,2 \\
& 9,2 & 12,0 & 29,0 & 68,3 & 58,6 \\
\hline \multirow{3}{*}{ Q1 } & 15,8 & 28,4 & 24,0 & 34,2 & 18,3 \\
& 13,2 & 8,7 & 14,0 & 5,7 & 37,9 \\
& 11,5 & 6,9 & 12,0 & 4,2 & 42,5 \\
& 5,9 & 6,3 & 9,0 & 34,4 & 30,0 \\
\hline & 29,9 & 15,7 & 42,0 & 28,8 & 62,6 \\
& 34,2 & 13,1 & 22,0 & 55,5 & 40,5 \\
& 12,7 & 10,2 & 15,0 & 15,3 & 32,0 \\
& 8,7 & 11,0 & 11,0 & 20,9 & 0,0 \\
\hline
\end{tabular}




\subsection{2 - Repetibilidade da técnica}

Através das Tabelas 5.1 e 5.3, observa-se que a repetibilidade entre valores de umidade volumétrica é menor nos ensaios inundados. Talvez, um dos fatores para tanto resida na penetração de água em alguns dos vazios existentes entre o solo e os segmentos de $50 \mathrm{~mm}$ da haste da sonda. Como constatam TOPP \& DAVIS (1985), em antenas paralelas segmentadas com descontinuidades não preenchidas, este fato pode provocar distorções nas leituras de $\varepsilon$.

Outro aspecto que pode afetar a repetibilidade diz respeito aos erros introduzidos pelo operador no momento da leitura do sinal no testador de cabos. Entretanto, isso pode ser evitado através da gravação do sinal para posterior análise. Este recurso foi utilizado em alguns ensaios inundados, como indicado na Tabela 5.1. Comparando os resultados obtidos em S1-r e MS3, nos quais se fez uso da gravação, com os dos demais ensaios inundados, nota-se que a gravação não contribuiu para o aumento da repetibilidade. Isso demonstra que as dispersões nos ensaios inundados resultam mais da presença da água, como explicado anteriormente, do que de erros cometidos no momento da leitura.

Para todas as provas de carga não inundadas, com exceção de Q1, o recurso da gravação também foi empregado. Na Tabela 5.3, percebe-se que, neste caso, os resultados para o ensaio Q1 apresentaram-se um pouco mais dispersos que os resultados correspondentes às demais provas de carga. Assim, a gravação do sinal mostrou-se mais necessária em provas de carga não inundadas, por aumentar a repetibilidade. Não obstante, convém ressaltar que gravação constitui um importante recurso em qualquer caso, pois permite uma análise muito mais cautelosa da resposta fornecida pelo equipamento, além da comodidade.

De qualquer forma, as dispersões entre os resultados são de difícil interpretação, pois além dos fatores supra mencionados que contribuem para tanto, pode-se ainda enumerar outros aspectos tais como a precisão inerente ao equipamento e eventuais variações de umidade no maciço durante as leituras de $\varepsilon$. 
Mesmo assim, os resultados obtidos através do equipamento utilizado no presente trabalho apresentaram um nível de repetibilidade superior ao descrito em TOPP et al. (1982b), que realizaram experimentos laboratoriais com sondas também segmentadas.

Por outro lado, analisando as Tabelas 5.2 e 5.4, constata-se que quando se trata de sucção matricial, ocorre uma inversão, sendo a repetibilidade nos ensaios inundados maior que nos não inundados. Uma explicação para tanto pode ser verificada através da Figura 5.9. Os valores de constante dielétrica para o solo inundado estão situados numa faixa da curva na qual grandes variações em $\varepsilon$ correspondem a variações pequenas na sucção. 


\section{7 - CONCLUSÕES E SUGESTÕES PARA PESQUISAS}

\section{FUTURAS}

\section{1 - CONCLUSÕES}

Do exposto no presente trabalho, pode-se concluir que:

a) a sucção matricial possui forte influência na capacidade de carga do solo. Um pequeno aumento na sucção causou um substancial crescimento da tensão de ruptura do solo;

b) para uma determinada tensão, comparando a curva relativa à prova de carga inundada (sucção zero) com as demais, observa-se que quanto maior a sucção apresentada no ensaio não inundado, maior foi a magnitude do colapso do solo;

c) as provas de carga mostraram um comportamento de encruamento do solo, no qual qualquer acréscimo de tensão causa um acréscimo de sua rigidez. Este comportamento manifestou-se para recalques além de $50 \mathrm{~mm}$ e independentemente do nível de sucção medido na prova de carga. Devido a isso, a aplicação do método de VAN DER VEEN (1953) tornou-se inadequada para a determinação da capacidade de carga;

d) os resultados das provas de carga mista apontam uma boa adequação do ensaio, denotando ser viável sua aplicação ao solo estudado; 
e) na prova de carga mista, a diminuição do incremento de carga pela metade na transição da fase lenta para a rápida revelou um comportamento particular traduzido pelo quase não desenvolvimento de deformação no primeiro estágio de carregamentos QML;

f) os resultados obtidos parecem indicar que o tipo de ensaio, seja SML ou QML, não é de grande relevância na resposta do sistema. Entretanto, deixa-se claro que um maior número de pares de ensaios rápidos e lentos com a mesma sucção é necessário em direção a análises mais conclusivas;

g) os reensaios mostraram tensões de colapso bastante superiores às dos ensaios inundados por causa da compactação sofrida, o que realça a eficácia do método de estabilização através de compactação do solo subjacente ao elemento de fundação superficial;

h) a reflectometria no domínio do tempo mostrou ser uma técnica promissora de campo para a obtenção de teor de umidade. Pode-se considerar o desempenho do equipamento como satisfatório, uma vez que seus resultados apresentaram-se em boa concordância com os obtidos por pesagem de amostras;

i) as comparações com ensaios de compressão confinada mostraram que os ajustes de variação da tensão de pré-adensamento com a sucção propiciaram boa estimativa da tensão de ruptura.

j) a simulação numérica realizada forneceu uma boa estimativa das curvas tensãorecalque das provas de carga. Em comparação com a tensão de ruptura média dos ensaios de campo, o erro cometido na previsão da tensão de ruptura foi inferior a $12 \%$. 


\section{2 - SUGESTÕES PARA PESQUISAS FUTURAS}

a) realizar provas de carga com inundação da cava durante o ensaio (sob diferentes tensões de inundação) e provas de carga com inundação prévia da cava, de modo a permitir comparações entre os dois procedimentos;

b) realizar um maior número de ensaios SML e QML com valores de sucção iguais ou próximos, de modo a possibilitar comparações para a verificação do tipo que melhor possa se adequar ao solo estudado;

c) executar um maior número de provas de carga em placa de um mesmo tipo e em diferentes níveis de sucção, a fim de se obter um suficiente número de pontos no gráfico tensão de ruptura-sucção e assim formar uma "superfície de escoamento de campo". Aplicar um modelo constitutivo para a representação do comportamento do solo e compará-lo aos dados de campo. 


\section{REFERÊNCIAS BIBLIOGRÁFICAS}

AGARWAL, K.B.; RANA, M. K. (1987). Effect of ground water on settlement of footings in sand. In: EUROPEAN CONFERENCE ON SOIL MECHANICS AND FOUNDATION ENGINEERING, 9. HANRAHANN, E. T.; ORR, T. L. L.; WIDDIS, T. F., eds. Dublin, 1987. Proceedings. Rotterdam, A. A. Balkema. v.2. p.751-754.

AGNELLI, N. (1992). Estudo da colapsividade do solo de Bauru através de provas de carga diretas. São Carlos. 172p. Dissertação (Mestrado) - Escola de Engenharia de São Carlos. Universidade de São Paulo.

AGNELLI, N. (1997). Comportamento de um solo colapsível inundado com líquidos de diferentes composições químicas. São Carlos. 219p. Tese (Doutorado) Escola de Engenharia de São Carlos. Universidade de São Paulo.

ALBIERO, J. H.; CARVALHO D.; LOBO A. S. (1993). Fundações. In: FERREIRA, A. A.; NEGRO JR. A.; AlBIERO, J. H.;CINTRA, J. C. A. orgs. Solos do interior de São Paulo. São Paulo, ABMS - USP/SC. Cap. 9, p. 245-278.

ALONSO, E. E.; GENS, A.; HIGHT, D. W. (1987). General Report - Special Problem Soils. In: EUROPEAN CONFERENCE ON SOIL MECHANICS AND FOUNDATION ENGINEERING, 9. HANRAHANN, E. T.; ORR, T. L.

L.; WIDDIS, T. F., eds. Dublin, 1987. Proceedings. Rotterdam, A. A. Balkema. v.3. p.1087-1146.

ALONSO, U. R. (1997). Prova de carga estática em estacas (uma proposta para revisão da norma da NBR 12131). Solos e Rochas, v.20, n.1, p.47-59, abr. 
AMAR, S.; BAGUELIN, F.; CANEPA, Y. (1987). Action du niveau de la nappe sur le comportement des fondations superficielles. In: EUROPEAN CONFERENCE ON SOIL MECHANICS AND FOUNDATION ENGINEERING, 9. HANRAHANN, E. T.; ORR, T. L. L.; WIDDIS, T. F., eds. Dublin, 1987. Proceedings. Rotterdam, A. A. Balkema. v.2. p.639-642.

ASSOCIAÇÃO BRASILEIRA DE NORMAS TÉCNICAS (1984). NBR 6489 Prova de carga direta sobre terreno de fundação. Rio de Janeiro.

ASSOCIAÇÃO BRASILEIRA DE NORMAS TÉCNICAS (1991). MB 3472 Estacas - Provas de Carga Estática. Rio de Janeiro.

ASSOCIAÇÃO BRASILEIRA DE NORMAS TÉCNICAS (1996). NBR 6122 Projeto e execução de fundação. Rio de Janeiro.

BAKER, J. M.; ALLMARAS, R. R. (1990). System for automating and multiplexing soil moisture measurement by time domain reflectometry. Soil Sci. Soc. Am. J., v.54, p.1-6.

BAKER, T. H.; GOODRICH, L. E. (1987). Measurement of soil water content using the combined time domain reflectometry - thermal conductivity probe. Canadian Geotechnical Journal, v.24; p. 160-163.

BARATA, F. E. (1984). Uma introdução ao projeto de fundações. Rio de Janeiro, Livros Técnicos e Científicos.

BAUMGARTNER, N.; PARKIN, G. W.; ELRICK, D. E. (1994). Soil water content and potential measured by hollow time domain reflectometry probe. Soil Sci. Soc. Am. J., v.58, p. 315-318. 
BJERRUM, L; EGGSTAD, A. (1963). Interpretation of loading tests on sand. In: EUROPEAN CONGRESS ON SOIL MECHANICS AND FOUNDATION ENGINEERING, 1. Wiesbaden, 1963. Proceedings. v.1, p. 199-204.

BORTOLUCCI, A. A. (1983). Caracterização geológico-geotécnica da região urbana de São Carlos-SP, a partir de sondagens de simples reconhecimento. São Carlos. Dissertação (Mestrado). Escola de Engenharia de São Carlos. Universidade de São Paulo.

BUTLER, H. D.; HOY, H. E. (1977). User's Manual for the Texas quick-load method for foundation load testing. Federal Highway Administration. Office of Development. Washington. 59p.

CARNEIRO, B. J.I.; CONCIANI, W.(1997).Emprego do TDR para acompanhar a evolução da infiltração de água no solo. In: SIMPÓSIO BRASILEIRO DE SOLOS NÃO SATURADOS, 3. CAMPOS, T. P. M.; VARGAS JR., E. A., eds. Rio de Janeiro, 1997. Anais. Rio de Janeiro, Freitas Bastos. v.1, p. 215220.

CARVALHO, D.; SOUZA, A. (1990). Análise do efeito do umedecimento do solo em fundações rasas e profundas em solos porosos. In: CONGRESSO BRASILEIRO DE GEOLOGIA DE ENGENHARIA, 6/ CONGRESSO BRASILEIRO DE MECÂNICA DOS SOLOS E ENGENHARIA DE FUNDAÇÕES, 9., Salvador, 1990. Anais. São Paulo, ABGE/ABMS. v. 2, p. 109-114.

CHIN, F. K. (1970). Estimation of the ultimate load of piles not carried to failure. In: SOUTHEAST ASIAN CONFERENCE ON SOIL ENGINEERING, 2. Proceedings. p. 81-90. 
CINTRA, J. C. A. ; CARVALHO, D. ; GIACHETTI, H. L.; BORTOLUCCI, A. A.; ALBIERO, J. H. (1991). Campo experimental de fundações em São Carlos. In: SEMINÁRIO DE ENGENHARIA DE FUNDAÇÕES ESPECIAIS, 2., São Paulo, 1985. Anais. São Paulo, ABMS/ABEF. v.1, p. 96 - 105.

CINTRA, J. C. A. (1995). Fundações em solos colapsíveis. Texto apresentado à Escola de Engenharia de São Carlos da Universidade de São Paulo para concurso de Livre Docência, 111p.

CINTRA, J. C. A. ; NOGUEIRA, J. B.; HERMANY F ${ }^{0}$, C. (1986). Shallow foundations on collapsible soils. In: INTERNATIONAL CONGRESS - IAEG, 5.,Buenos Aires, 1986. Proceedings. Rotterdam, A. A. Balkema. v.3, p. 673675.

CONCIANI W. (1997). Estudo do colapso do solo através de ensaios de placa monitorados com tensiômetros e tomografia computadorizada. São Carlos. 181p. Tese (Doutorado) - Escola de Engenharia de São Carlos. Universidade de São Paulo.

CONCIANI, W.; HERMANN, P. S.; SOARES, M. M. (1995). The time domain reflectometry to study matrix suction. In: CONFERENCE ON UNSATURATED SOILS, 1, Paris, 1995. Proceedings. Rotterdam, A. A. Balkema, v.3, p. 1481-1486.

CONCIANI, W.; HERRMANN, P. S. P; MACHADO, S. L.; SOARES, M. M. (1996). O uso da técnica de reflectometria no domínio do tempo (TDR) para determinação da umidade do solo in situ. Solos e Rochas, v. 19, n.3, p.189-199.

CONSOLI, N.; SCHNAID, F.; MILITITSKY, J. (1998). Interpretation of plate load tests on residual soil site. Journal of Geotechnical and Geoenvironmental Engineering, v. 124. n. 9, p. 857-867. 
COOK, D. L.; FREDLUND, D. G. (1998). TDR matric suction measurements. INTERNATIONAL CONFERENCE ON UNSATURATED SOILS, 2. Beijing, 1998. Proceedings. Beijing, v.1, p. 338-343.

DASBERG, S.; HOPMANS, J. W. (1992). Time domain reflectometry calibration for uniformly and nonuniformly wetted sandy and clayey loam soils. Soil Sci. Soc. Am. J., v.56, p. 1341-1345.

DAVISSON, M. T. (1972). High capacity piles. Proceedings, Lecture Series, Innovations in Foundation Construction. ASCE. Illinois Section. 52p.

De BEER., E. E. (1967). Proefondervindelijke bijdrage tot de studie van het grensdraag vermogen van zand onder funderingen op staal. Tijdshrift der Openbar Werken van Beigie Nos.

De MELLO, V. F. B. (1975). Deformações como base fundamental da escolha da fundação. Geotecnia, n.12, p. 55-75.

DÉCOURT, L. (1991). General report: Part A - Shallow foundations and displacement piles. In: PANAMERICAN CONFERENCE, IX.1991. Proceedings. p.1953-1997.

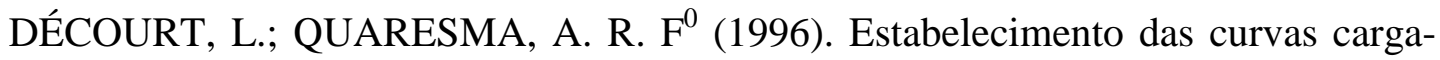
recalque de fundações através de provas de carga em mini-placa. In: SEMINÁRIO DE ENGENHARIA DE FUNDAÇÕES ESPECIAIS E GEOTECNIA, 3., São Paulo, 1996. Anais. São Paulo, ABMS/ABEF. v.2, p. 225-235.

DUNCAN, J. M.; CHANG, C. Y. (1970). Nonlinear Analysis of stress and strain in soils. Journal of the Soil Mechanics and Foundation Division, ASCE, v.96, n.SM5, p.1629-1654. 
FELLENIUS, B. H. (1975). The load of piles and new proof testing procedure. In: Journal of the Geotechnical Engineering Division, ASCE, v.101, n.GT9, p.855869.

FERREIRA, R. C.; PERES, J. E. E.; BENVENUTO, C. (1990). Uma análise de modelos geotécnicos para a previsão de recalques em solos colapsíveis. In: CONGRESSO BRASILEIRO DE GEOLOGIA DE ENGENHARIA, 6/ CONGRESSO BRASILEIRO DE MECÂNICA DOS SOLOS E ENGENHARIA DE FUNDAÇÕES, 9., Salvador, 1990. Anais. São Paulo, ABGE/ABMS. v. 2, p. 73-79.

FERREIRA, S. R. M.; FUCALE, S. P.; AMORIM, S. F. (1998). Comportamento de variação de volumes em solos colapsíveis avaliados por meio de ensaios de campo. In: CONGRESSO BRASILEIRO DE MECÂNICA DOS SOLOS E ENGENHARIA GEOTÉCNICA, XI, Brasília, 1998. Anais. Brasília, ABMS. v. 1, p. 171-178.

FREDLUND, D. G.; MORGENSTERN, N. R. (1977). Stress state variables for unsaturated soils. In: Journal of the Geotechnical Engineering Division, ASCE, v. 103, n. GT5, p.447-466.

FREDLUND, D. G.; RAHARDJO, H. (1993). Soil Mechanics for Unsaturated Soils. New York, John Wiley \& Sons.

FREDLUND, D. G.; XING, A. (1994). Equations for the soil water characteristic curve. Canadian Geotechnical Journal, v.31, n.4.

FÚlfARO, V. J.; BJONBERG, A. J. S. (1993). Geologia. In: FERREIRA, A. A.; NEGRO JR. A.; ALBIERO, J. H.;CINTRA, J. C. A. orgs. Solos do interior de São Paulo. São Paulo, ABMS - USP/SC. Cap. 1, p. 1-42. 
FULlER, F. M.; HOY, H. E. (1970). Pile load tests including quick-load test method, conventional methods and interpretations. Highway Research Board, 333. p 78-86.

GIACHETI, H. L.; RÖHM, S. A.; NOGUEIRA, J. B.; CINTRA, J. C. A. (1993). Propriedades geotécnicas do sedimento cenozóico. In: FERREIRA, A. A.; NEGRO JR. A.; ALBIERO, J. H.;CINTRA, J. C. A. orgs. Solos do interior de São Paulo. São Paulo, ABMS - USP/SC. Cap. 6, p. 143-175.

GORBUNOV-POSSADOV, M. I.; DAVYDOV, S. S. (1973). Interaction of soil bases and structures (prediction of settlement, design of massive foundations based on the limiting state, design of flexible foundation beams and slabs). In: INTERNATIONAL CONFERENCE ON SOIL MECHANICS AND FOUNDATION ENGINEERING, VIII, Moscow, 1973, v.3, p. 46-92.

GRIGORIAN, A. A. (1997). Pile foundations for buildings and structures in collapsible soils. A. A. Balkema.

HANSEN, J. B. (1970). A revised and extended formula for bearing capacity. (English version) Geoteknisk Institut Bulletin no. 28, Copenhagen.

HERKELRATH, W. N.; HAMBURG, S. P.; MURPHY, F. (1991). Automatic, real time monitoring of soil moisture in a remote field area with time domain reflectometry. Water Resource Research, v.27, n.5, p.857-864.

HUANG, F. H.; DOWDING, C. H. (1998). Telemetric and multiplexing enhancement of time domain reflectometry measurements. http://iti.acns.nwu.edu/pubs/telemtry.pdf.

INSTITUTO DE PESQUISAS TECNOLÓGICAS (1954). Estudo das fundações para as futuras instalações da Escola de Engenharia de São Carlos. Relatório $\mathrm{n}^{0}$ 2269. São Paulo. 
INSTITUTO DE PESQUISAS TECNOLÓGICAS (1991). Provas de carga em fundações. São Paulo.

JACOBSEN, O. H.; SCHJONNING, P. (1993). A laboratory calibration of time domain reflectometry for soil water measurement including effects of bulk density and texture. Journal of Hydrology, 151, p.147-157.

KNIGHT, J. H. (1992). Sensitivity of time domain reflectometry measurements to lateral variations in soil water content. . Water Resource Research, v.28, n.9, p.2345-2352.

KRAUS, J. D. (1984). Eletromagnetics. 3 ed. New York, McGraw-Hill.

KUJALA, K.; RAVASKA, O. (1994) Soil water content measurement with a time domain reflectometry. In: INTERNATIONAL CONFERENCE OF SOIL MECHANICS AND FOUNDATION ENGINEERING, XIII., New Delhi, 1994. Proceedings. Rotterdam, A. A. Balkema, v.1, p.219-224.

LAMBE, T. W. (1973). Predictions in soil engineering. Géotechnique, v.23, n.2, p. 149-202.

LOPES, G. S.; ROCHA, E. M.; MINETTE, E.; AZEVEDO, R. F. (1998). Análise, em termos de capacidade de carga, de uma prova de carga direta em verdadeira grandeza em solo residual de gnaisse. In: CONGRESSO BRASILEIRO DE MECÂNICA DOS SOLOS E ENGENHARIA GEOTÉCNICA COBRAMSEG, XI, 1998, Brasília, Anais. v.3, p.1497-1504.

MACHADO, S. L. (1998). Aplicações de conceitos de elastoplasticidade a solos não saturados. Tese (Doutorado) - Escola de Engenharia de São Carlos. Universidade de São Paulo. 362p. 
MARTINS, F. F.; MARTINS, J. B. (1997). Comparison between some plate tests results and theoretical calculations. In: INTERNATIONAL CONFERENCE ON SOIL MECHANICS AND FOUNDATION ENGINEERING, IV, 1997. Proceedings. Rotterdam, A. A. Balkema. v.1, p. 543-546.

MAZURKIEWICZ, B. K. (1972). Test loading of piles according to Polish regulations. Royal Swedish Academy of Eng. Sciences. Stockholm. 20p. (Report n. 35).

MELLIOS, G. A. (1985). Provas de carga em solos porosos. In: SEMINÁRIO DE ENGENHARIA DE FUNDAÇÕES ESPECIAIS,2., São Paulo, 1985. Anais. São Paulo, ABMS/ABEF. v.2, p. 73-102.

MELLO, L. G. F. S.; CEPOLLINA, M.(1978). Sobre a interpretação de provas de carga sobre placas visando previsão de recalques. In: CONGRESSO BRASILEIRO DE MECÂNICA DOS SOLOS E ENGENHARIA DE FUNDAÇÕES, 6., Rio de Janeiro, 1978. Anais. São Paulo, ABMS. v. 1, p. 165-180.

MEYERHOF, G. G. (1951). The ultimate bearing capacity of foundations. Géotechnique, v. 1, n. 4, p. 351.

MEYERHOF, G. G. (1955). Influence of roughness of base and ground-water conditions on the ultimate bearing capacity of foundations. Géotechnique, v. 5, n. 3, p.227-242.

MIGUEL, M. G. (1996). Execução e análise de provas de carga horizontal em estacas em solo colapsível. Dissertação (Mestrado) - Escola de Engenharia de São Carlos. Universidade de São Paulo. 
MILITITSKY, J. (1991). Provas de carga estáticas. In: SEMINÁRIO DE ENGENHARIA DE FUNDAÇÕES ESPECIAIS, 2., São Paulo, 1991. Anais. v.2, p.203-228.

NADEO, J. R.; VIDELA, E. P. (1975). El fenomeno de la humecation in situ de suelos colapsibles. In: CONGRESSO PANAMERICANO DE MECÂNICA DOS SOLOS E ENGENHARIA DE FUNDAÇÕES, 5, 1975, Buenos Aires, (5), p. 313-319.

NÁPOLES NETO (1954). Estudo dos recalques de um grande castelo d'água fundado em solo residual. In: CONGRESSO BRASILEIRO DE MECÂNICA DOS SOLOS E ENGENHARIA DE FUNDAÇÕES, 1. Porto Alegre, 1954.

NIYAMA, S.; AOKI, N.; CHAMECKI, P. M. (1996). Verificação de desempenho. In: HACHICH et al. eds. Fundações Teoria e Prática. São Paulo, PINI. Cap. 20, p. 723-751.

PETERSEN, L. W.; THOMSEN, A.; MOLDRUP, P.; JACOBSEN, O. H.; ROLSTON, D. E. (1995). High-resolution time domain reflectometry: sensitivity dependency on probe design. Soil Science. v. 159, n.3, p. 149-154.

PHENE II, C. J.; DUTTAGUPTA, R. R.; PHENE, R. R.; TOJEIRO, T. (1988). In situ measurements of soil matric potential using the time domain reflectometry technique./ Agronomy Abstracts. American society of agronomy - Crop Science Society of America - Soil Science Society of America. p. 188, California, 1988.

POULOS, H. G.; DAVIS, E. H. (1973). Elastic solutions for soil and rock mechanics. New York, John Willey \& Sons.

REZNIK, Y. M. (1993). Plate load tests of collapsible soils. Journal of the Geotechnical Engineering Division, ASCE, v.119, n.GT3, p. 608-615. 
ROCHA $F^{0}$, P. (1985). Interpretação de provas de carga utilizando-se de formulação tipo meio homogêneo equivalente. In: SEMINÁRIO DE ENGENHARIA DE FUNDAÇÕES ESPECIAIS, 2., São Paulo, 1985. Anais. São Paulo, ABMS/ABEF. v.2, p. 137-146.

SILVA, J. C. B. J. (1990). Análise dos resultados de provas de carga em estacas de pequeno diâmetro em solo colapsível. In: CONGRESSO BRASILEIRO DE MECÂNICA DOS SOLOS E ENGENHARIA DE FUNDAÇÕES COBRAMSEF, IX, 1990, Salvador, Anais. São Paulo, ABMS. v. 2, p. 125131.

SIMONS, N. E.; MENZIES B. K. (1981). Introdução à engenharia de fundações. Rio de Janeiro, Interciência.

SOUTO SILVEIRA, E. B. S. \& SILVEIRA, A. (1958). Investigação do arenito decomposto de São Carlos, para fundação de pequenas construções. In: CONGRESSO BRASILEIRO DE MECÂNICA DOS SOLOS E ENGENHARIA DE FUNDAÇÕES, 2., Recife (PE)/ Campina Grande (PB), 1958. Anais. São Paulo, ABMS. v. 1, p. 77-110.

SOUZA, A.; CINTRA, J. C. A. (1994). Fundações rasas no solo colapsível de Ilha Solteira - SP. In: CONGRESSO BRASILEIRO DE MECÂNICA DOS SOLOS E ENGENHARIA DE FUNDAÇÕES, 10., Foz do Iguaçu, 1994. Anais. São Paulo, ABMS. v. 1, p. 223-230.

SOWERS, G. F. (1962). Shallow foundations. In: LEONARDS, G. A. ed. Foundation Engineering. McGraw-Hill. Cap. 6, p. 525-632.

STEENFELT, J. S. (1987). General Report. In: EUROPEAN CONFERENCE ON SOIL MECHANICS AND FOUNDATION ENGINEERING, 9. HANRAHANN, E. T.; ORR, T. L. L.; WIDDIS, T. F., eds. Dublin, 1987. Proceedings. Rotterdam, A. A. Balkema. v.3. p.1285-1298. 
STEESEN-BACH, J. O.; FOGED, N.; STEENFELT, J. S. (1987). Capillarity induced stresses-Fact or fiction? In: EUROPEAN CONFERENCE ON SOIL MECHANICS AND FOUNDATION ENGINEERING, 9. HANRAHANN, E. T.; ORR, T. L. L.; WIDDIS, T. F., eds. Dublin, 1987. Proceedings. Rotterdam, A. A. Balkema. v. 1. p.83-89.

TEIXEIRA, A. H.; GODOY, N. S. (1996). Análise, projeto e execução de fundações rasas. In: HACHICH et al. eds. Fundações Teoria e Prática. São Paulo, PINI. Cap. 7, p. 227-264.

TEIXEIRA, C. Z.; ALBIERO, J. H.; CARVALHO, D. (1996). Capacidade de carga de fundações rasas. In: SEMINÁRIO DE ENGENHARIA DE FUNDAÇÕES ESPECIAIS E GEOTECNIA, 3., São Paulo, 1996. Anais. São Paulo, ABMS/ABEF. v.2, p. 309-316.

TERZAGHI, K. (1943). Theoretical soil mechanics. 1 ed. New York, John Willey \& Sons.

TERZAGHI, K.; PECK, R. B. (1948). Soil mechanics in engineering practice. New York, John Willey \& Sons.

TERZAGHI, K.; PECK, R. B. (1967). Soil mechanics in engineering practice.2. ed. New York, John Willey \& Sons.

TOPP, G. C.; DAVIS, J. L (1985). Measurement of soil alwater content using time domain reflectometry (TDR). A field evaluation. Soil Science Society American Journal. v.49, p. 19-24.

TOPP, G. C.; DAVIS, J. L.; ANNAN, A. N. (1980). Electromagnetic determination of soil water content: measurements in coaxial transmission line. Water Resource Research, v.16, n.3, p.574-582. 
TOPP, G. C.; DAVIS, J. L.; ANNAN, A. P. (1982a). Electromagnetic determination of soil water content using TDR: I. Applications to wetting fronts and steep gradients. Soil Sci. Soc. Am. J., v.46, p. 672-678.

TOPP, G. C.; DAVIS, J. L.; ANNAN, A. P. (1982b). Electromagnetic determination of soil water content using TDR: II. Evaluation of installation and configuration of parallel transmission lines. Soil Sci. Soc. Am. J., v.46, p. 678684.

TOPP, G. C.; DAVIS, J. L.; BAILEY, W. G.; ZEBCHUK, W. D. (1984). The measurement of soil water content using a portable TDR hand probe. Canadian Journal Soil Science, v.64, 313-321.

VAN DER VEEN, C. (1953). The bearing capacity of a pile. In: INTERNATIONAL CONFERENCE ON SOIL MECHANICS AND FOUNDATION ENGINEERING, 3. Switzerland, v.2, p. 84-90.

VELLOSO, P.P.C.; GRILLO, S. Q.; PENEDO, E. J. (1978). Observações sobre a capacidade de carga e o módulo de deformação de solo por meio de provas de carga e ensaios de laboratório. In: CONGRESSO BRASILEIRO DE MECÂNICA DOS SOLOS E ENGENHARIA DE FUNDAÇÕES, 6., Rio de Janeiro, 1978. Anais. São Paulo, ABMS. v. 1, p. 305-327.

VESIC, A. S. (1963). Bearing capacity of deep foundations in sand. Highway Research Record, 39. National Academy of Sciences, National Research Council. p. 112-153.

VILAR, O. M. (1979). Estudo da compressão unidirecional do sedimento moderno (solo superficial) da cidade de São Carlos. São Carlos. Dissertação (Mestrado). Escola de Engenharia de São Carlos. Universidade de São Paulo. 
ZEGELIN, S. J.; WHITE, I.; JENKINS, D. R. (1989). Improved field probes for soil water content and electrical conductivity measurements using time domain reflectometry. Water Resource Research, v.25, n.11, p.2367-2376. 
ANEXO A - Curvas tensão versus recalque inicial e estabilizado

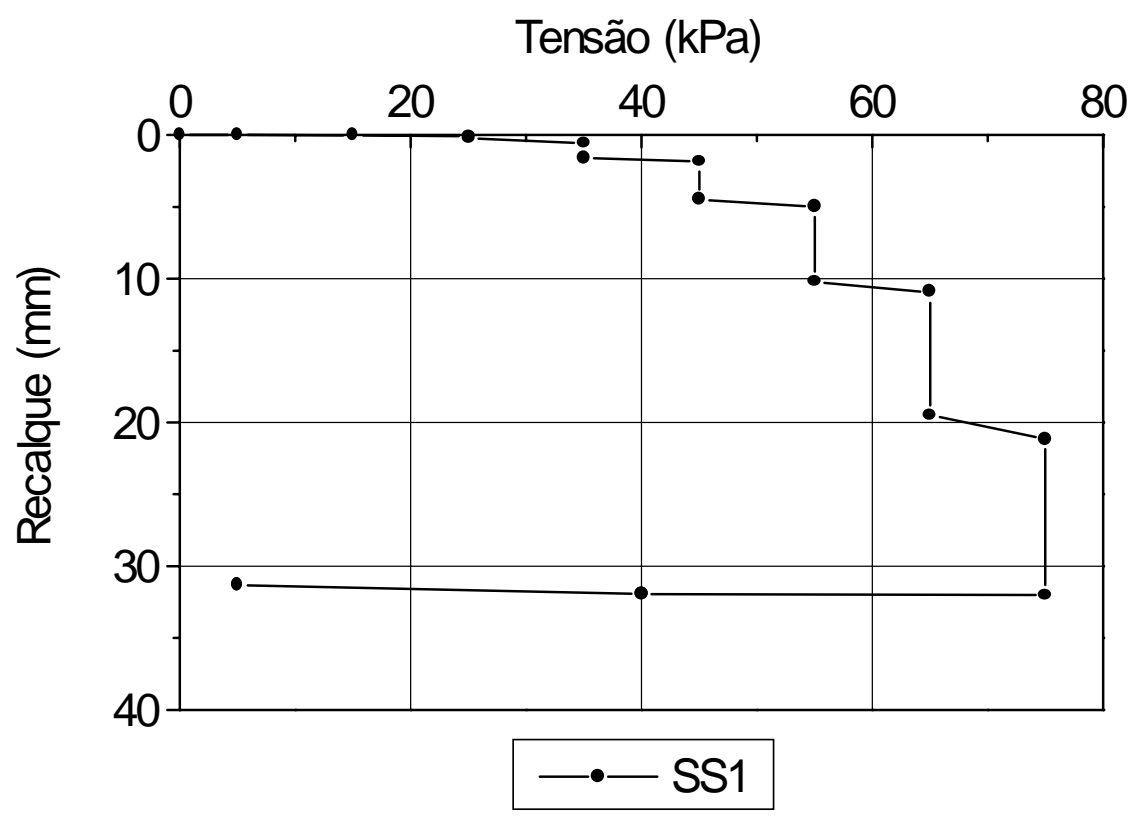

FIGURA 1 - Ensaio SS1

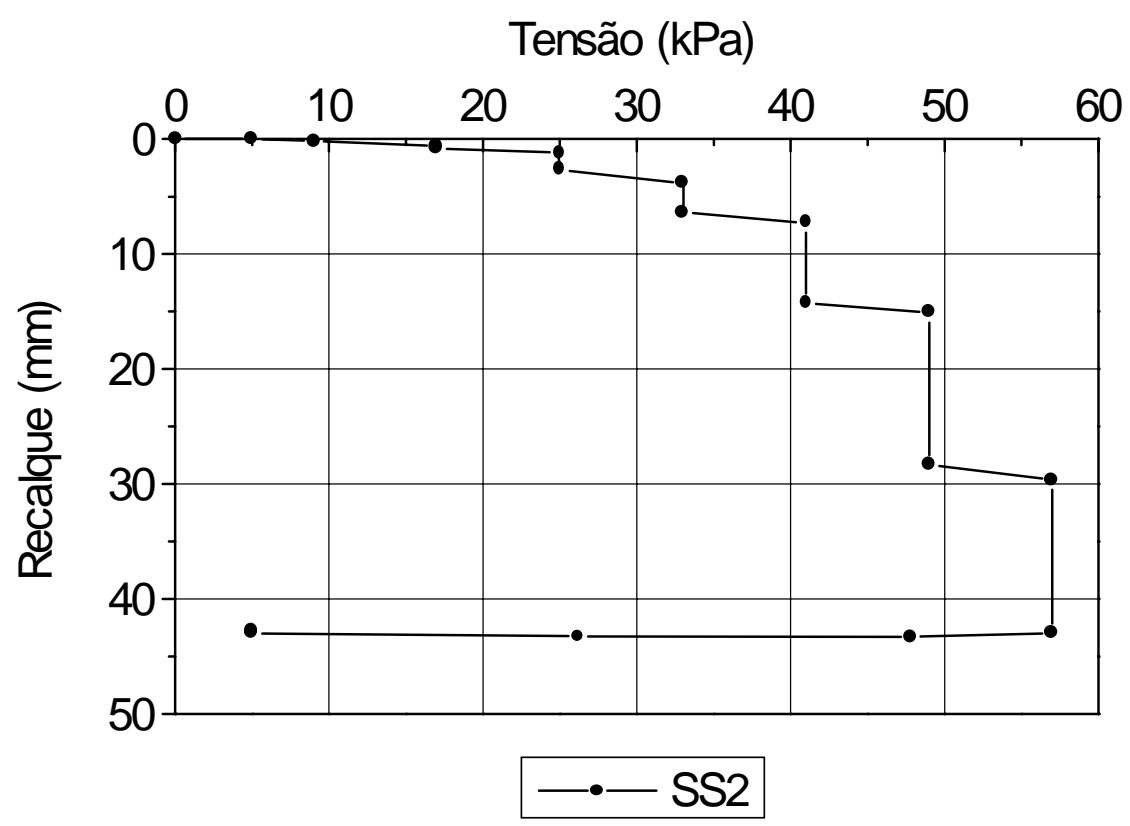

FIGURA 2 - Ensaio SS2 


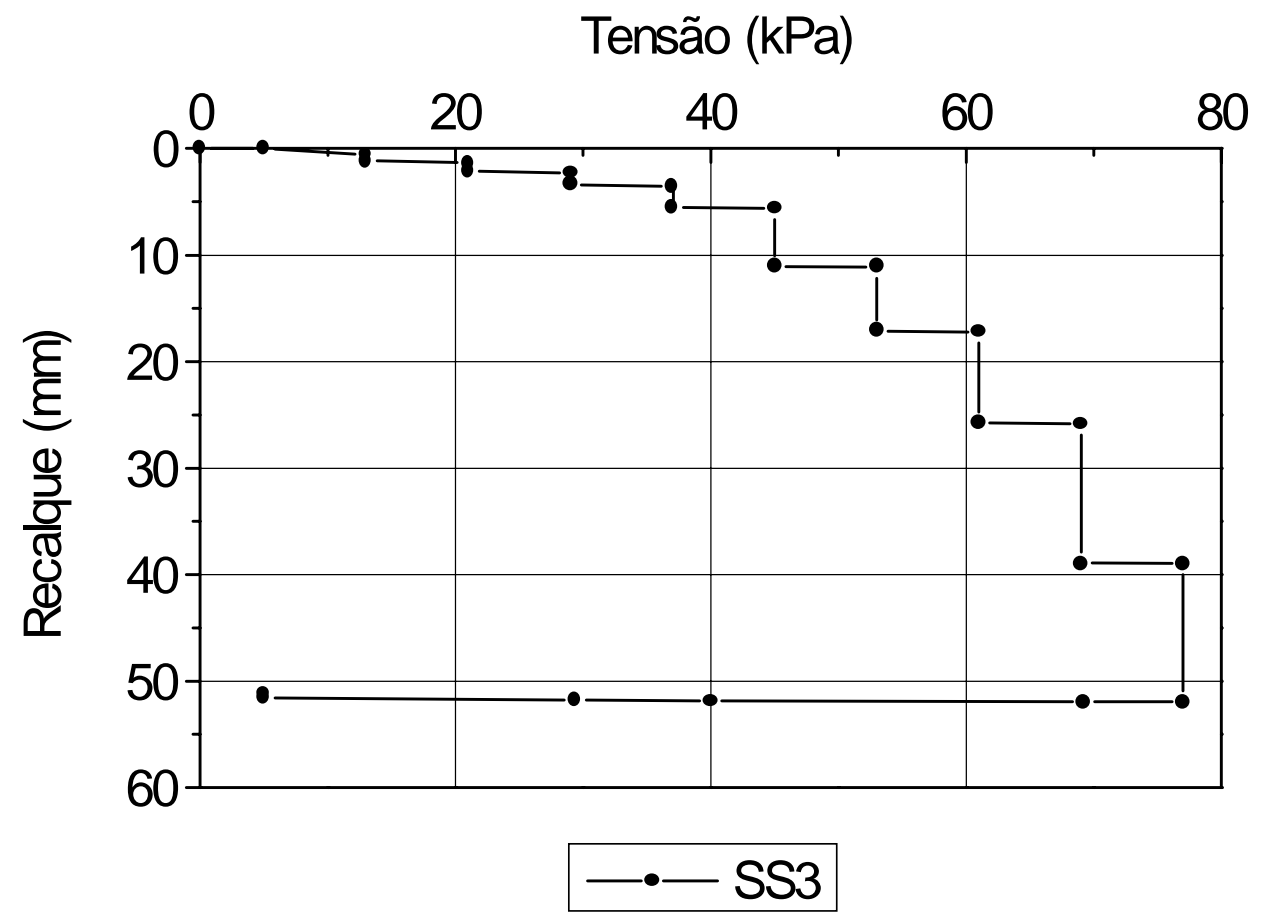

FIGURA 3 - Ensaio SS3

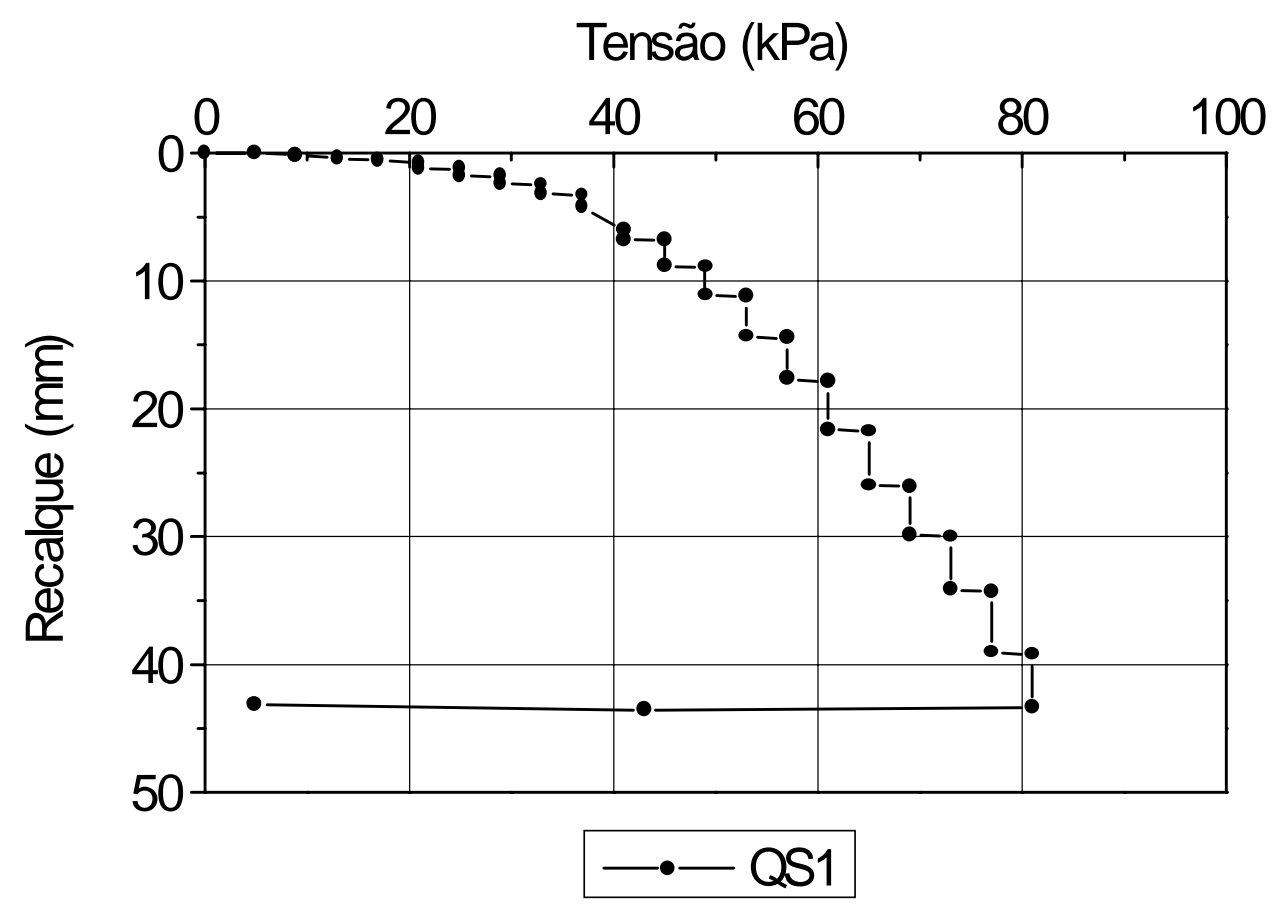

FIGURA 4 - ensaio QS1 


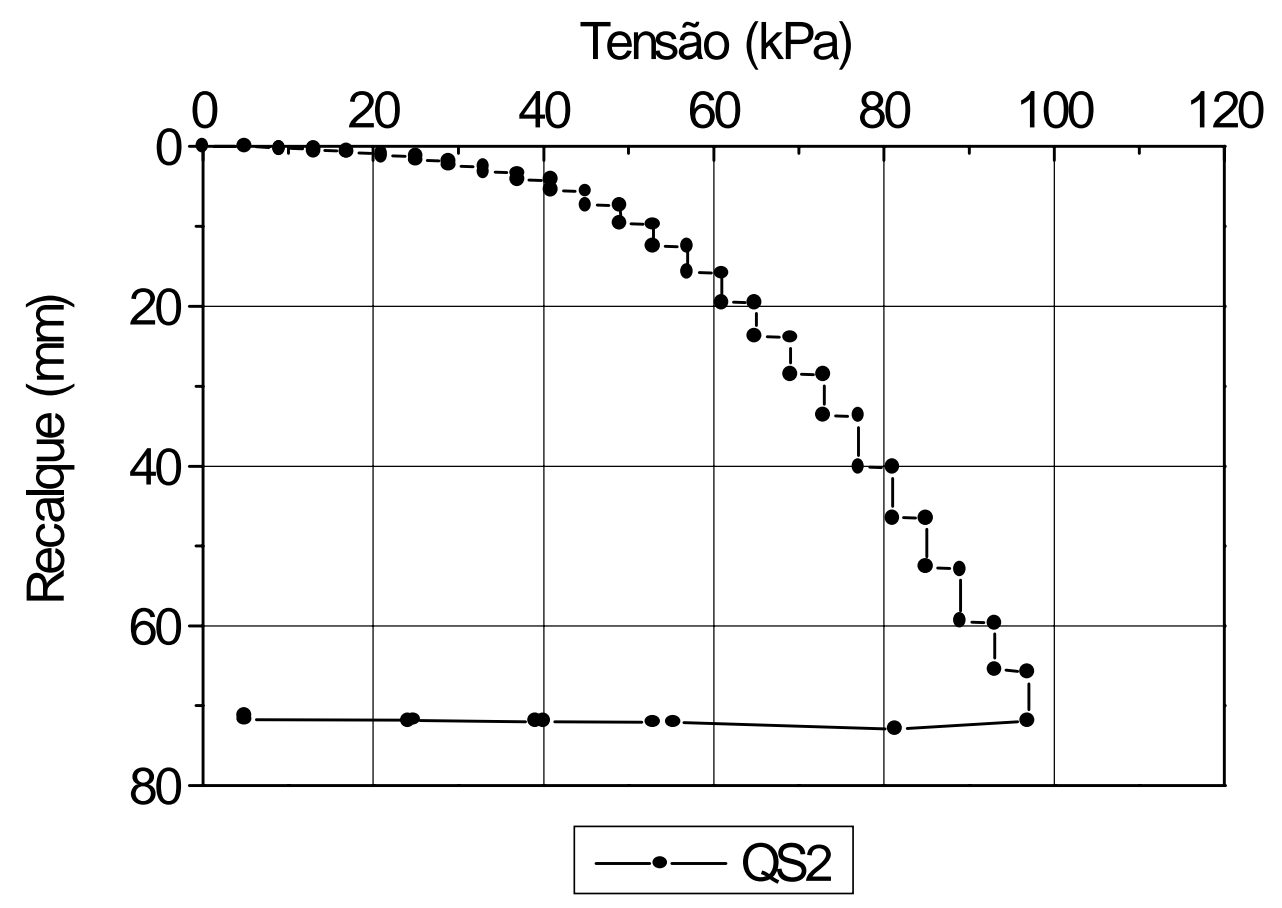

FIGURA 5 - Ensaio QS2

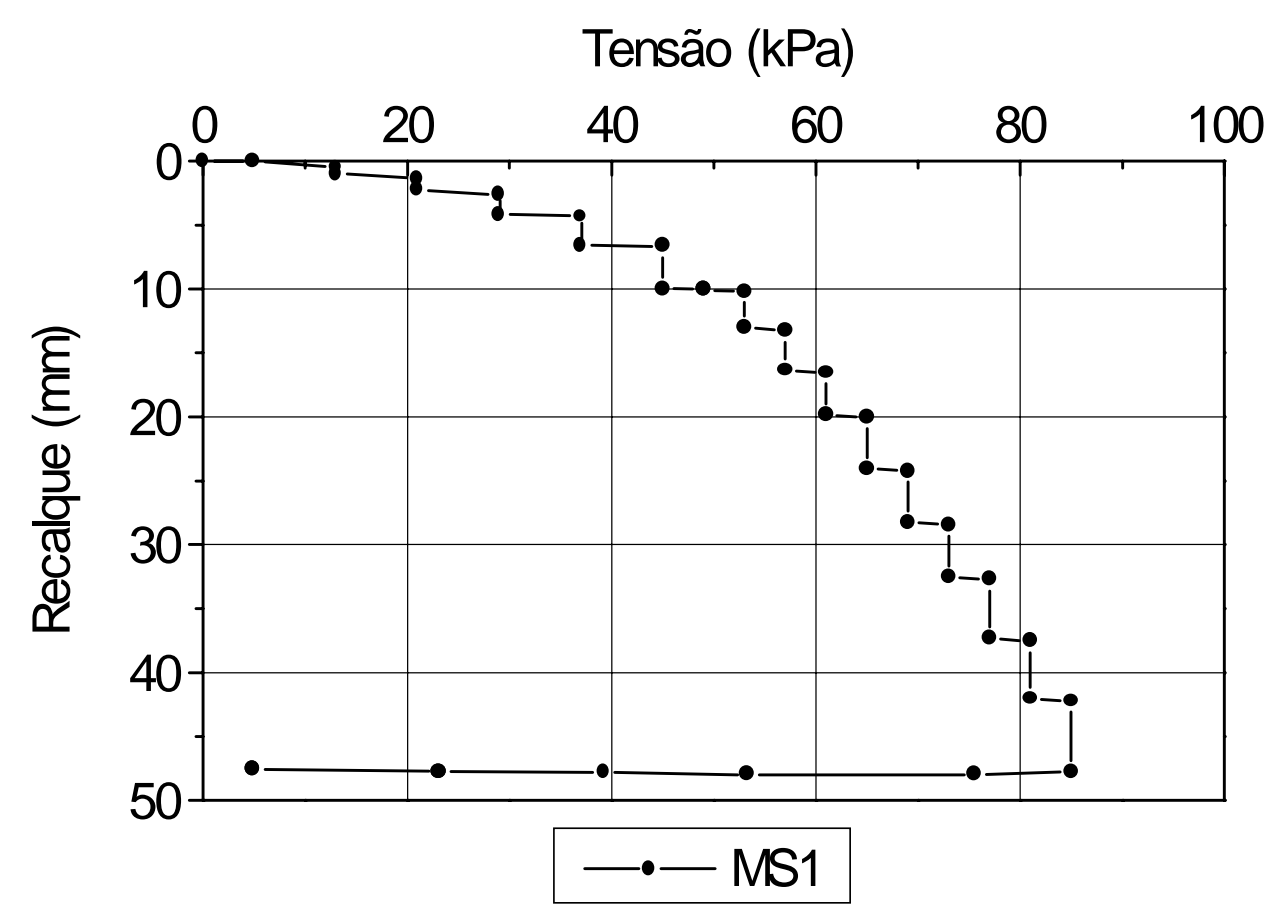

FIGURA 6 - Ensaio MS1 


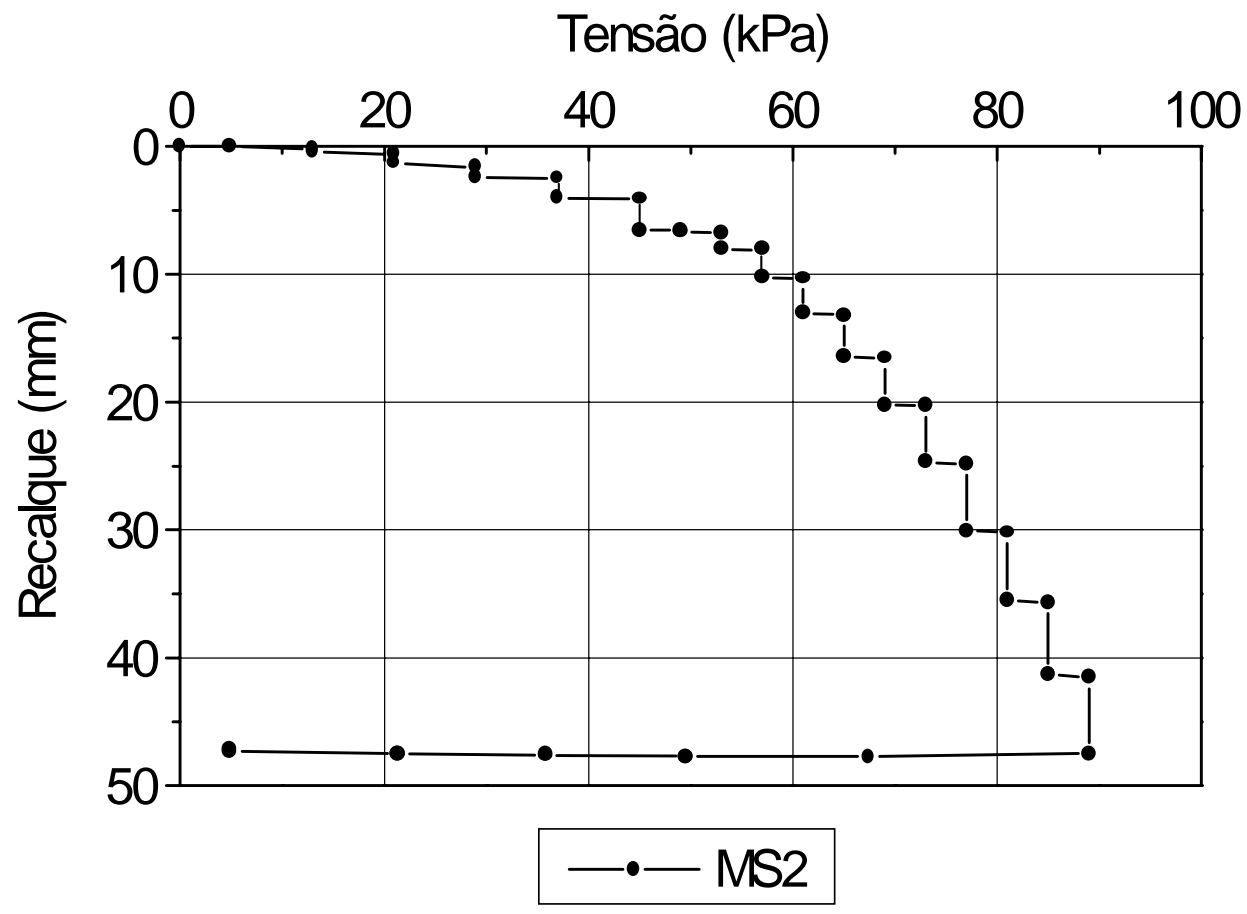

FIGURA 7 - Ensaio MS2

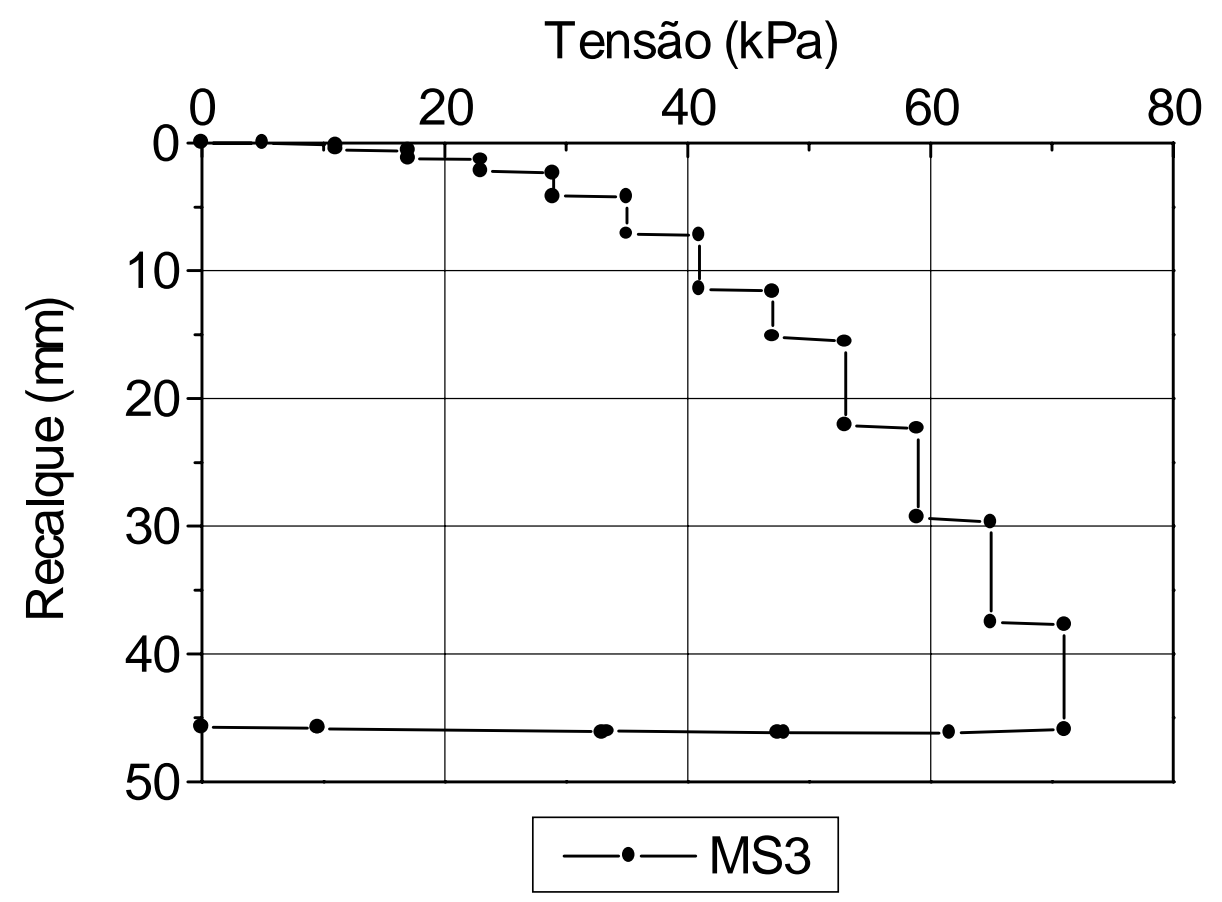

FIGURA 8 - Ensaio MS3 


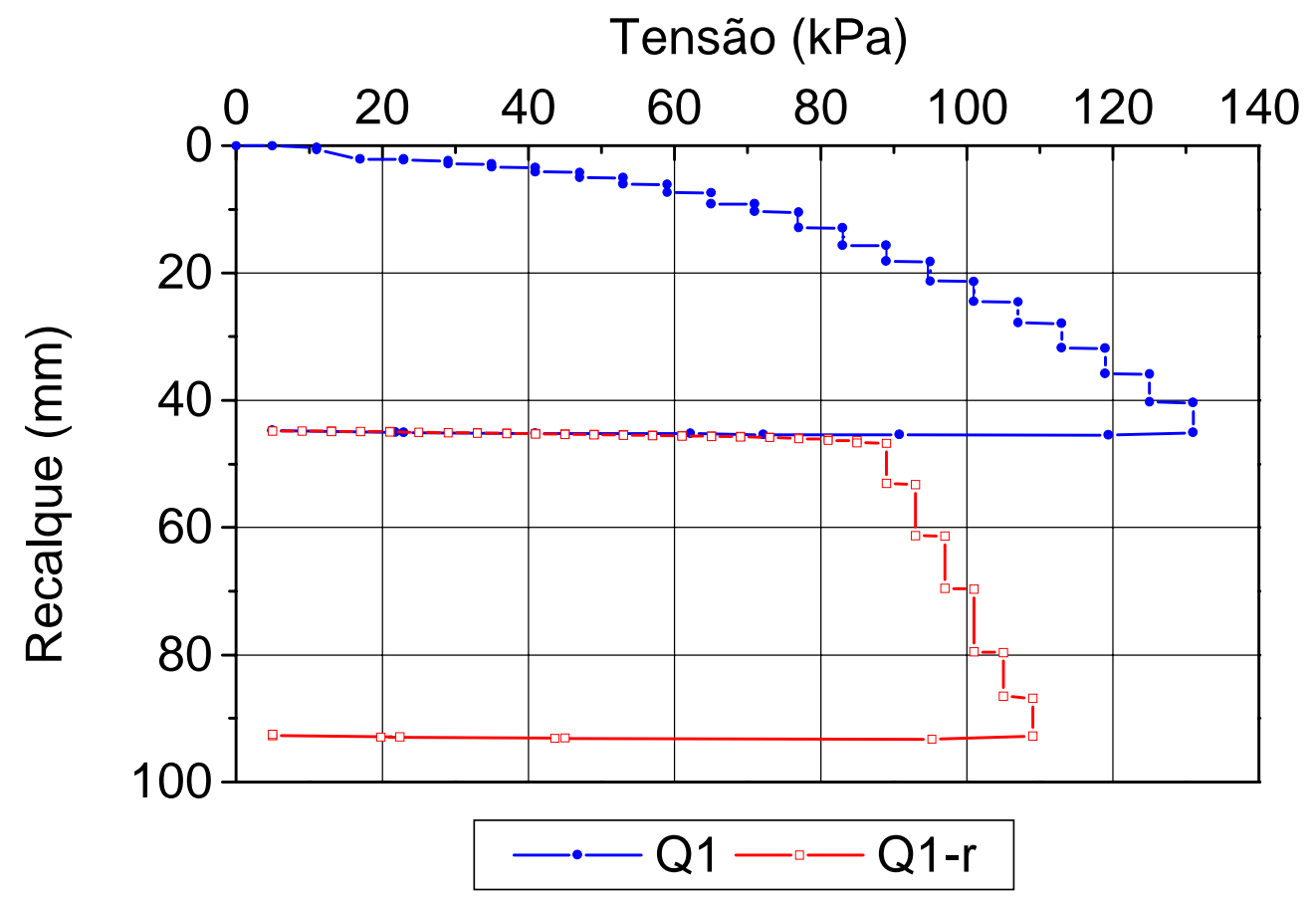

FIGURA 9 - Ensaio Q1 e reensaio Q1-r

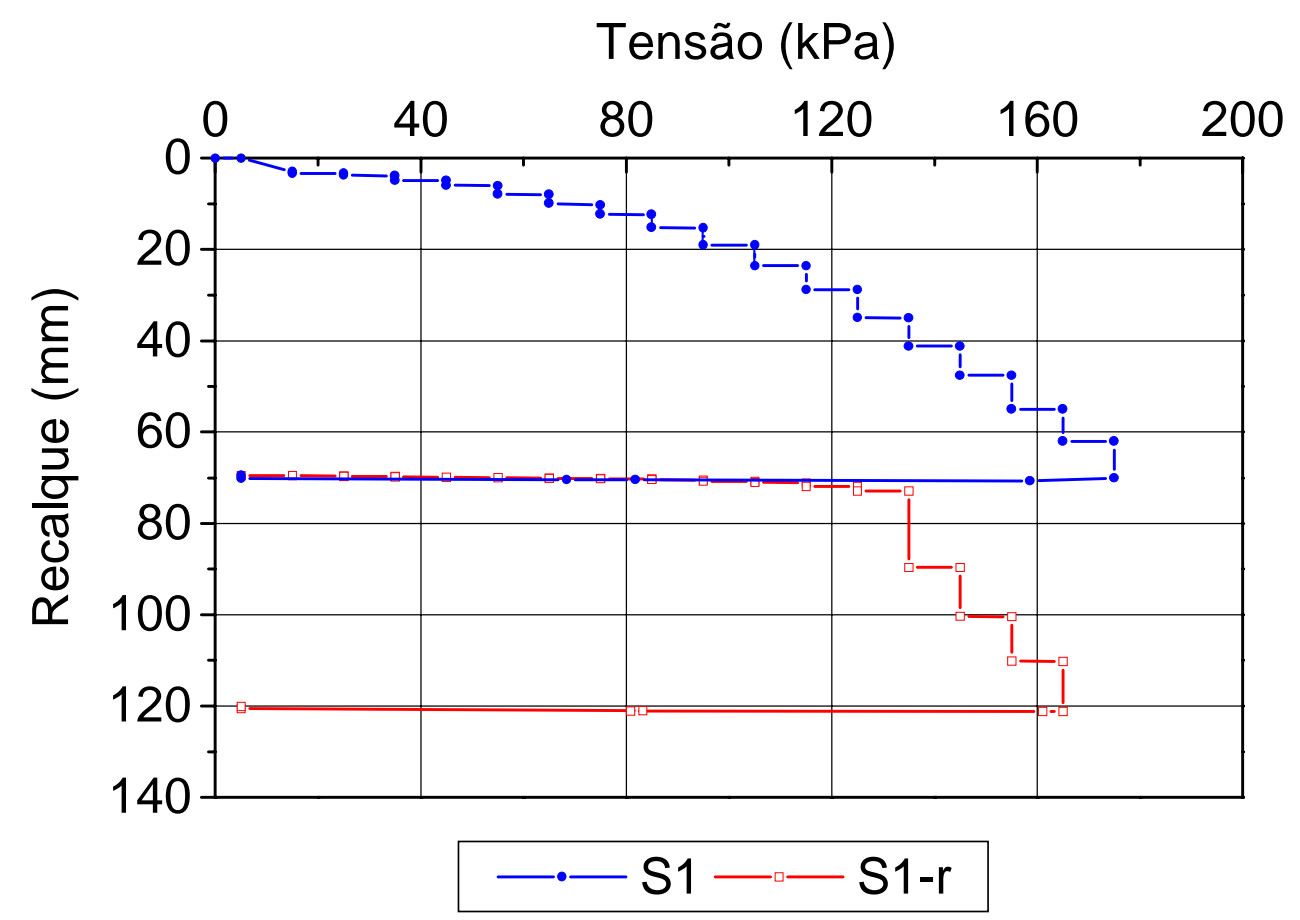

FIGURA 10 - Ensaio S1 e reensaio S1-r 


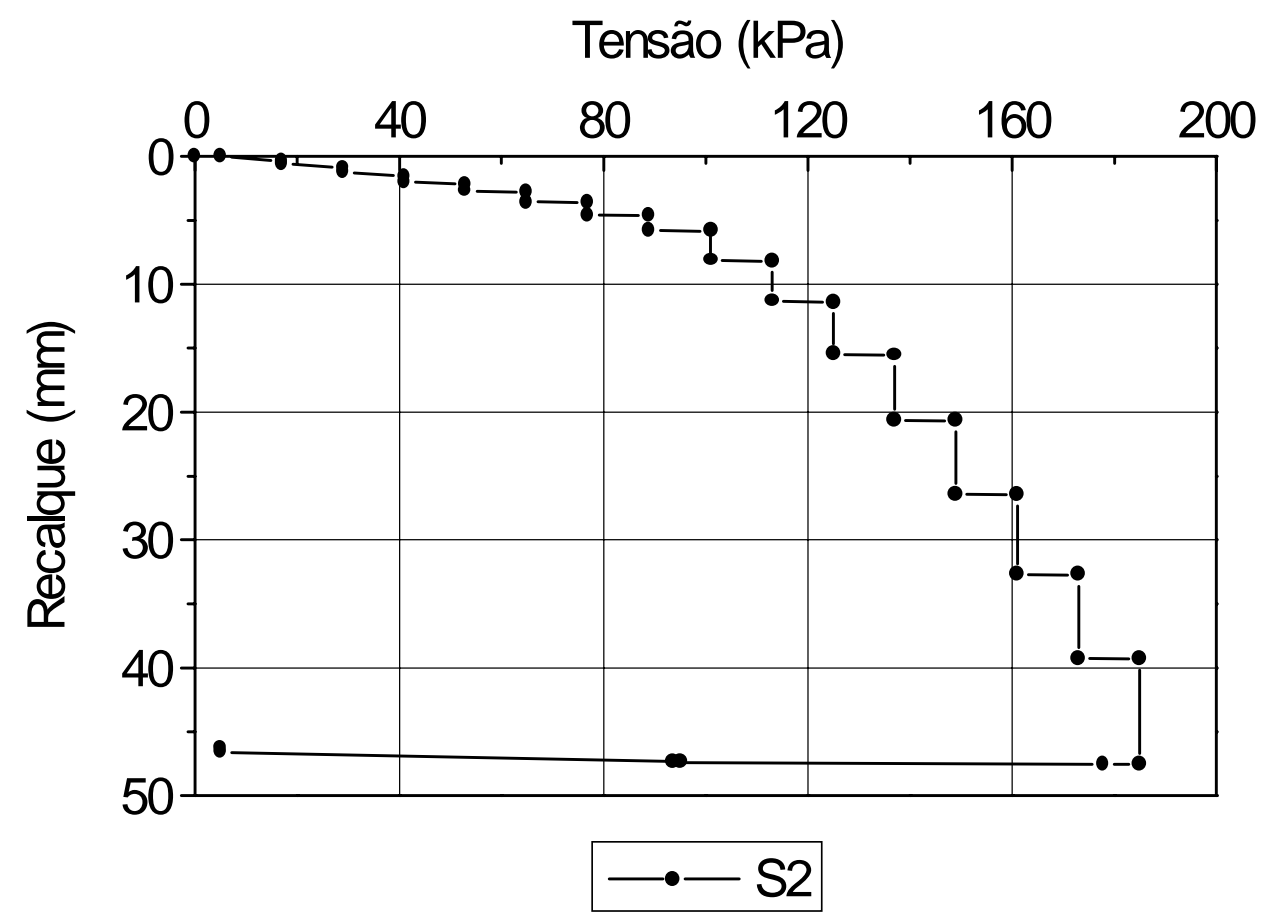

FIGURA 11 - Ensaio S2

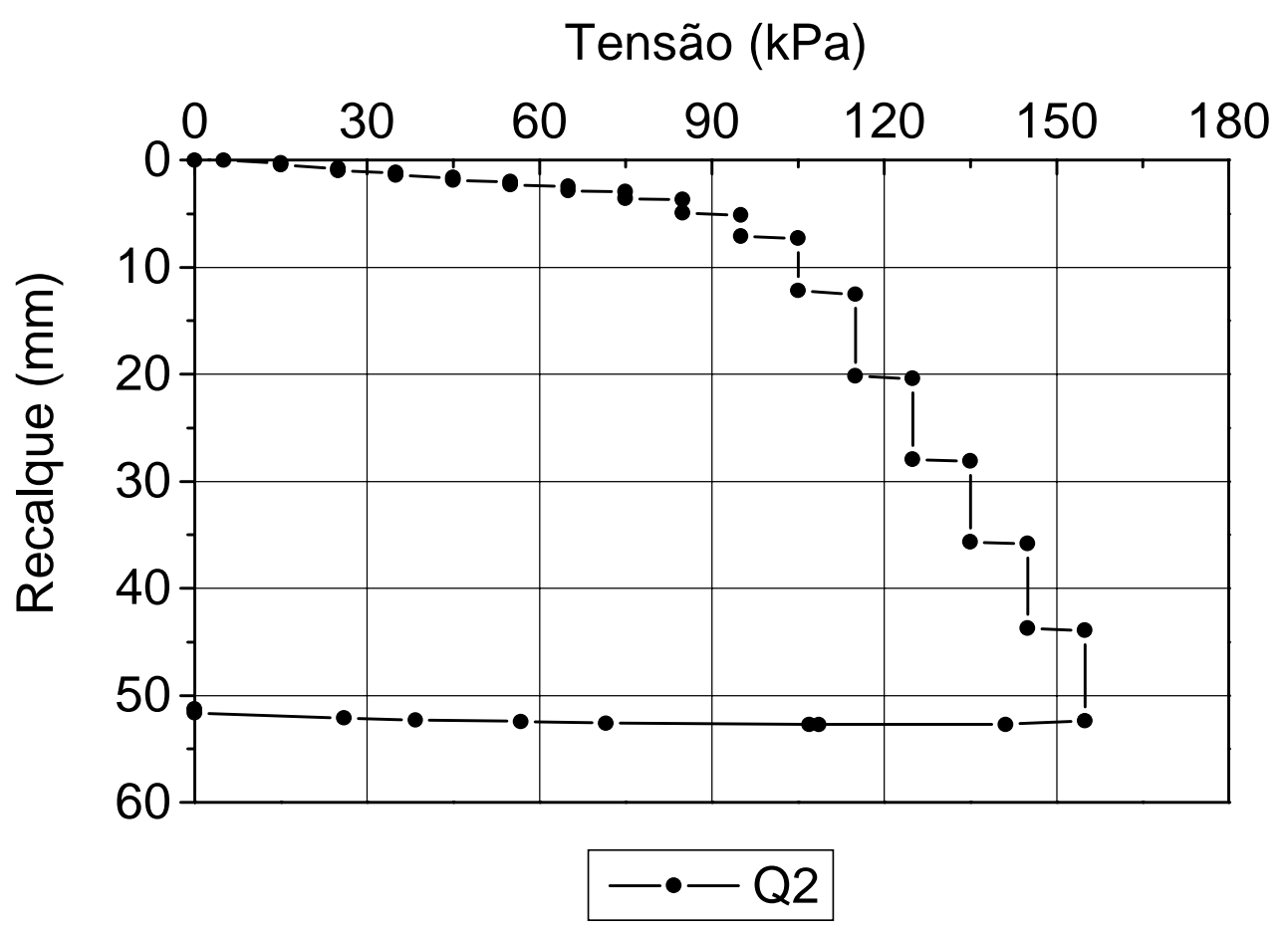

FIGURA 12 - Ensaio Q2 


\section{ANEXO B - Curva de calibração da célula de carga}

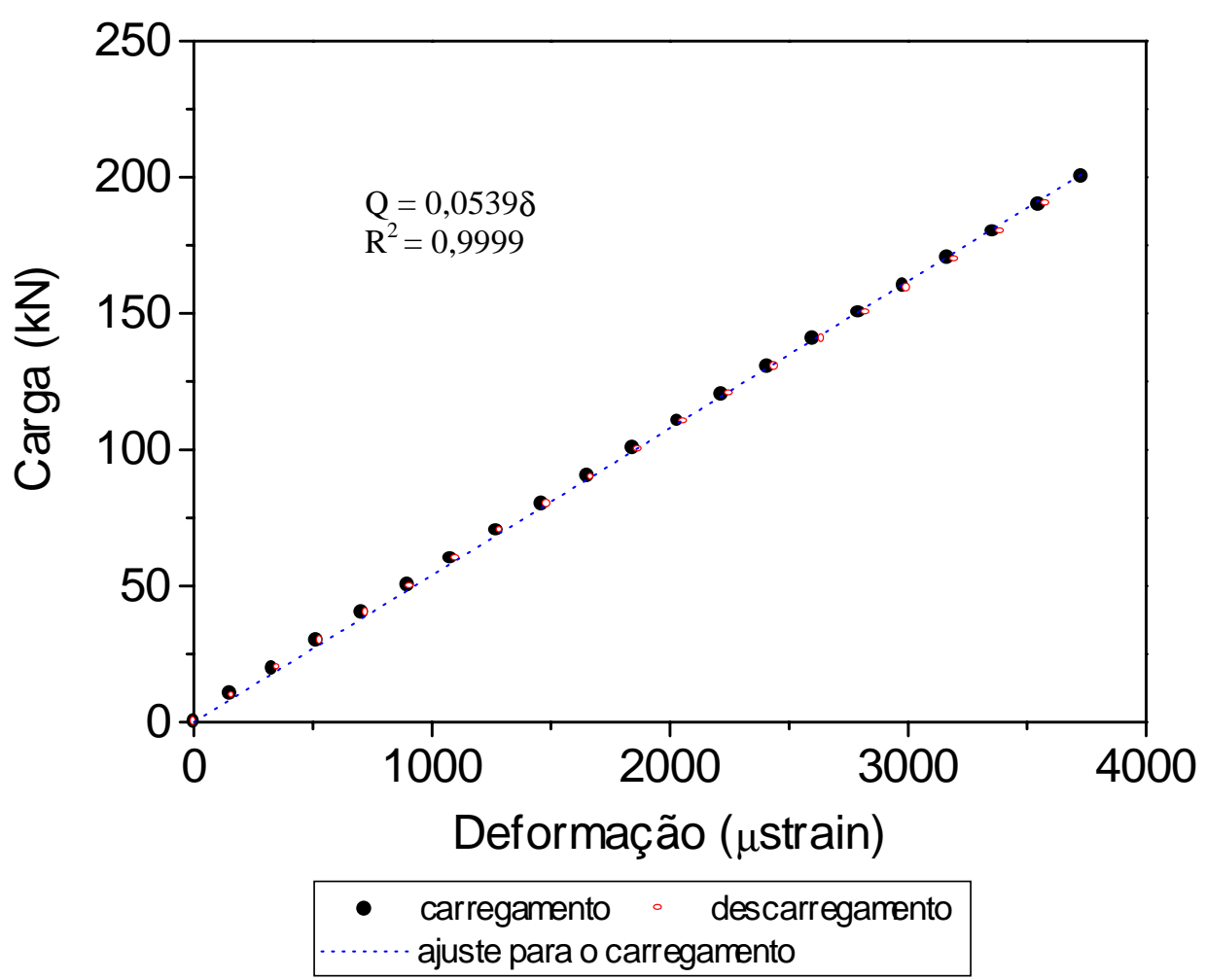

FIGURA 1 - Curva de calibração da célula de carga utilizada nas provas de carga 